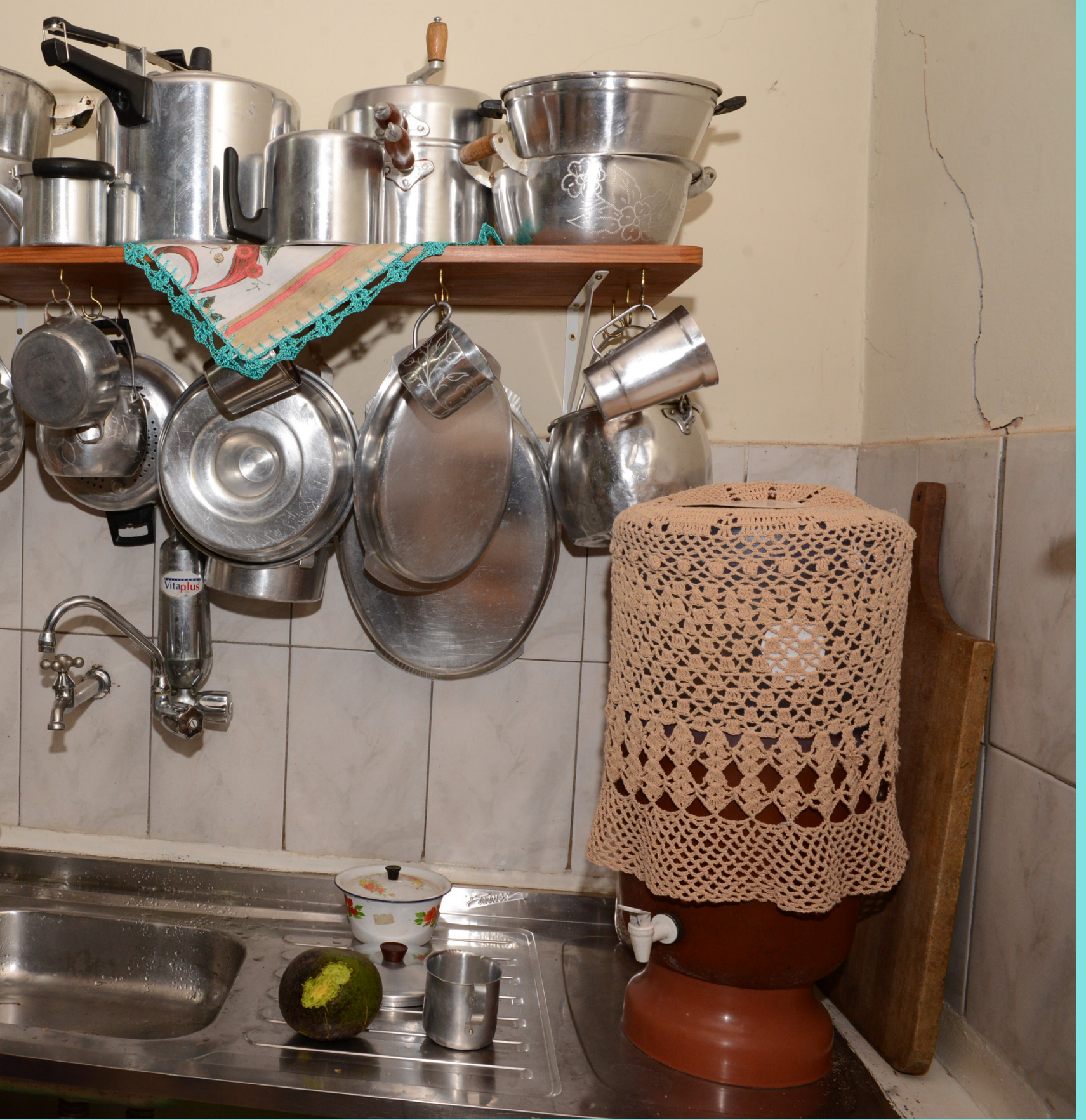

Maria Beatriz Ardinghi

\title{
Glossário visual popular paulista: artefatos memoráveis presentes em residências de famílias de origem rural no estado de São Paulo
}



Universidade de São Paulo

Faculdade de Arquitetura e Urbanismo

Maria Beatriz Ardinghi

\section{Glossário visual popular paulista:}

artefatos memoráveis presentes em residências de famílias de origem rural no estado de São Paulo 

Maria Beatriz Ardinghi

\section{Glossário visual popular paulista:}

artefatos memoráveis presentes em residências de famílias de origem rural no estado de São Paulo

Dissertação apresentada a Faculdade de Arquitetura e Urbanismo da Universidade de São Paulo para obtenção do título de Mestre em Arquitetura e Urbanismo

Área de concentração: Design e Arquitetura

Orientadora: Prof. ${ }^{a}$ Dr. ${ }^{a}$ Priscila Lena Farias 
Autorizo a reprodução e divulgação total ou parcial deste trabalho, por qualquer meio convencional ou eletrônico, para fins de estudo e pesquisa, desde que citada a fonte.

E-mail da autora:

beatrizardinghi@gmail.com

Ardinghi, Maria Beatriz

A676g Glossário visual popular paulista: artefatos memoráveis presentes em residências de famílias de origem rural no estado de São Paulo / Maria Beatriz Ardinghi. -- São Paulo, 2015.

273 p. : il.

Dissertação (Mestrado - Área de Concentração: Design e Arquitetura) - FAUUSP.

Orientadora: Priscila Lena Farias

1.Design vernacular 2.Identidade cultural 3.Cultura material 4.Folclore 5.Artefatos de memória I.Título

CDU 7.05 
ARDINGHI, Maria Beatriz

Glossário visual popular paulista: artefatos

memoráveis presentes em residências de

famílias de origem rural no estado de São Paulo

Dissertação apresentada a Faculdade de Arquitetura e Urbanismo da

Universidade de São Paulo

para obtenção do título de Mestre em

Arquitetura e Urbanismo.

Data:

Banca examinadora:

Julgamento:

Orientadora: Prof. ${ }^{a}$ Dr. ${ }^{\text {a }}$ Priscila Lena Farias

Universidade de São Paulo

Julgamento:

Nome:

Instituição:

Julgamento:

Nome:

Instituição:

Julgamento:

Nome (suplente):

Instituição:

Julgamento:

Nome (suplente):

Instituição: 

Este trabalho é dedicado à memória do meu bisavô, o folclorista Amadeu Amaral, cuja obra em torno das tradições populares serviu de referência e inspiração para este e tantos outros projetos. 



\section{Agradecimentos}

A Priscila Farias, por sua preciosa orientação e pelo cuidado e respeito com que tratou minhas dúvidas e inseguranças.

A D. Julia e ao Sr. Rozendo Joia; D. Zulmira Carmello Lourenção; D. Amélia Russo Varotti (in memorian) e a Regina Varotti Brumati; a D. Maria Almeida Maciel, sua filha Ester e sua neta Mariane; a D. Luiza Duarte Novaes Rodrigues e sua neta Larissa; a D. Thereza, Sr. Valdemar Stella, seu neto Andrey e sua adorável família; a Isabel Cristina Neris Pachere e sua filha Ariane; a D. Aurelina Dias dos Santos, D. Rosalina Pereira da Silva Souza e sua filha Luciana; a D. Nair de Andrade Mello e Sr. João Batista de Pádua Mello; a D. Sebastiana e D. Leonilda Toetz; a D. Maria Cecilia Correr e Sr. Orlando Correr; a D. Lucy Santana Martins; ao Sr. Ciro Rodrigues Machado; a D. Dalva Olinda Moretti de Camargo, Sr. Pedro Camargo e D. Zica Camargo; a D. Regina Augusto da Luz; a D. Maria de Lourdes Fernandes Machado, Sr. Ademar Machado e sua filha Adriana; a D. Vanda dos Santos Gouvêa, Luciana de Lara e D. Sueli Aparecida da Silva; meu muito obrigada por terem me recebido em suas casas e compartilhado comigo detalhes de tantas vidas.

A Ana Paula Almeida, Ana Renata Galvão Gonçalves, Ana Vasconcelos, André Almeida, Andre Pinotti, Belarmino Cesar Guimarães da Costa, Carina Martellini, Cassília Brumati, Cilene Cunha Silva, Daniela Molena Marchiori, Daniele Zandoná, Daniella Rubbo Rodrigues Rondelli, Denilson Rivail Holmo, Diego Normandi, Ed Marcos Sarro, Eduardo Domingues Oliveira, Eliete Mariani, Érika do Amaral Pozetti Judice, Fabiana Olivieri, Fabiano Pereira, Freddy Van Camp, José Claudio Brollo, Joyce Romano, Larissa Meo, Leandro Velloso, Marcelo Rigolino, Maria Regina Sarro, Mauro Carmello, Quelen Cristina Torres Pedro, Renato Elston Gomes, Ricardo Trevisan, Rui Alão, Satoshi Yoshimura, Suzana Padovano, Vania Bitencour, Victor Kraide, Vitor Hugo Parisi Ramos, Viviane Lopes Faria e Wesley Honorio por suas memórias e seus relatos, sem os quais não teria sido possível este trabalho.

A Eliete Soares, fotógrafa e amiga, pela disposição em me acompanhar em grande parte das visitas de campo, meu muito obrigada pela companhia e pelas fotografias.

A todos aqueles que, de alguma forma, colaboraram com este trabalho com valiosas contribuições, em especial a Cibele Haddad Taralli, Clice de Toledo Sanjar Mazzilli, Daniela Kutschat Hanns, Fernanda Rodrigues Rossi, Luís Cláudio Portugal do Nascimento, Luis Henrique Mello, Lygia Arcuri Eluf, Marcos da Costa Braga, Maria Aparecida Carmello, Maria Cecília Loschiavo dos Santos, Olga von Simson, Oliver Mann, Rosaelena Scarpeline e compadre Timóteo da Fazenda Chocolate, em Itu.

Aos meus colegas da pós-graduação pelas trocas prazerosas.

A minha família pelo apoio e torcida, em especial a minha mãe por suas leituras e eterno interesse.

Ao meu amor, companheiro paciente durante esta longa travessia. 

"Na realidade, não há percepção que não esteja impregnada de lembranças." Henri Bergson 



\section{Resumo}

O propósito desta pesquisa é contribuir para os estudos da cultura material popular brasileira em relação à possibilidade da existência de identidades regionais do artefato brasileiro popular, sob a ótica do design. Para tanto, foram identificados e analisados, do ponto de vista da percepção, uso e significado, determinados artefatos domésticos considerados memoráveis e notáveis em residências de famílias de origem rural no estado de São Paulo.

Tendo em vista o pressuposto de que esses artefatos correspondem à materialidade presente nas memórias afetivas de uma parte significativa da população paulista, foram analisados seus atributos formais, funcionais e simbólicos relevantes e recorrentes, a fim de se identificar uma possível linguagem regional do objeto popular - documentada na forma de um glossário visual, que possa servir de referência e inspiração ao design contemporâneo preocupado com as questões acerca das identidades culturais.

O método utilizado partiu de entrevistas e coleta de depoimentos informais para a caracterização dos artefatos chamados memoráveis, isto é, que participaram de vivências afetivas da infância de parte da população adulta selecionada. A partir daí, efetuou-se uma pesquisa de campo a fim de se identificar estes artefatos presentes em residências de paulistas idosos de origem rural, distribuídas por sete regiões do estado de São Paulo, de modo a compor um acervo de artefatos notáveis, fazendo uso de registros fotográficos e entrevistas semiestruturadas para a coleta de dados. Em seguida, foram analisados seus atributos formais e funcionais bem como os significados a eles atribuídos por seus usuários dentro do contexto em que estão inseridos.

Como fatores determinantes na escolha do tema destacam-se: a questão da identidade no discurso do design e sua relação com as memórias afetivas e a cultura material popular; a ausência de estudos semelhantes na área do design que abordem temas usualmente discutidos em estudos das ciências sociais e que contemplem as questões pertinentes ao design de artefatos; e, finalmente, um novo objeto de interesse nos estudos folclóricos: o artefato doméstico ordinário de uso cotidiano, comumente encontrado em residências de pessoas idosas de origem rural no interior do estado de São Paulo.

Ao final da pesquisa pudemos concluir que é possível caracterizar a identidade do artefato popular paulista de acordo com suas características de uso, percepção e significado, e que esta identidade está intimamente ligada à sua origem sociocultural e histórica.

Palavras-chave: Design vernacular; Identidade cultural; Cultura material; Folclore; Artefatos de memória 



\section{Abstract}

The purpose of this research is to contribute to the study of popular material Brazilian culture in relation to the possibility of regional identities of the popular artifact, from the perspective of design. In order to do so, it was identified and analyzed aspects of perception, use and meaning of a number of domestic artifacts considered memorable that can be found in rural origin family homes in the state of São Paulo

Considering that these artifacts correspond to the materiality present in affective memories of a significant part of São Paulo's population, it was analyzed their formal, functional and symbolic attributes in order to identify their language - documented in the form of a visual glossary, which can be reference and inspiration to contemporary designers concerned with cultural identities issues.

The method used in this study is based on interviews and the collection of informal testimonials to characterize what we call memorable artifacts, which are objects that participated in childhood affective experiences of the selected adult population.

After that, a field survey was carried out to identify these artifacts present in São Paulo residences of elderly rural origin, spread across seven regions of the state of São Paulo, through photographic records and interviews. Then, it was analyzed their formal and plastic attributes in order to identify a possible regional language of popular household objects and the meanings given to them by their users.

The theme of this research results from the discussion about cultural identity in the design field and its relation with memories and material culture. Another reason for that is due to the lack of similar studies in design to address issues usually discussed in researches from the social sciences. Finally, it represents a new object of interest in the study of folklore: the ordinary household artifacts of everyday use, commonly found in elderly homes of rural origin in the state of São Paulo.

At the end of this study, it was concluded that it is possible to characterize the identity of popular São Paulo artifact according to their usage characteristics, perception and meaning. In addition, it is possible to state that this identity is related to their social, cultural and historical origin.

Keywords: Vernacular design; Cultural identity; Material culture; Folklore; Memorable artifacts 



\section{Lista de figuras}

Figura 1. Toalha de plástico e garrafa térmica com café, Monte Aprazível. Registro fotográfico da autora, $2014 ; 32$

Figura 2. Pano de prato com rosas pintadas à mão, Campinas. Registro fotográfico da autora, 2014; 32

Figura 3. Vasos com samambaias pendurados na garagem, Monte Aprazível. Registro fotográfico da autora, $2014 ; 32$

Figura 4. Diagrama conceitual que embasa o estudo. Elaborado pela pesquisadora, 2015; 43

Figura 5. Almanaque Jeca Tatuzinho, 35. ed., 1973. Disponível em: <http://almanaque.blog.br/tag/jeca-tatu/>. Acesso em: 8 nov. 2015; 52

Figura 6. Propaganda de remédio para amarelão. In: ALMANAQUE do Biotônico, 1935, p. 4 (Ilustração: J. U. Campos). Disponível em: <http://portaldoprofessor.mec.gov.br/fichaTecnicaAula.html?aula=31264>. Acesso em: 7 de junho de 2014; 53

Figura 7. Jeca Tatu de Mazzaropi, 1959. Disponível em: <http://www.centenariomazzaropi.org.br/o-grandeamigo-jeca-tatu/>. Acesso em: 8 nov. 2015; 53

Figura 8. Identidade visual do Espaço Pindorama de Festas Infantis. Design: Rex Design. (Reproduzido de CONSOLO, 2009, p. 132); 71

Figura 9. Postal Carioca, design de Bruno Porto. (Reproduzido de CONSOLO, 2009, p. 125); 71

Figura 10. Brinde PS.2 2007/2008. Design ps.2 arquitetura + design. (Reproduzido de CONSOLO, 2009, p. 131); 72

Figura 11. Cesta de pães. Design: Luiz Galvão. FUCAPI - Fundação Centro de Análise, Pesquisa e Inovação Tecnológica. Disponível em: <http://www.fucapi.br/blog/2013/09/design-amazonico-ganha-premio-em-feira-internacional-na-franca> . Acesso em: 3 Ago. 2014; 72

Figura 12. Imigrantes aguardando exame médico no pátio da Hospedaria, década de 1930. Acervo virtual do Museu da Imigração do Estado de São Paulo. Disponível em: <http://museudaimigracao.org.br>. Acesso em: 29 jul. 2014; 78

Figura 13. Alojamento e família de imigrante russo em Nova Odessa, 1906. Acervo virtual do Museu da Imigração do Estado de São Paulo. Disponível em: <http://museudaimigracao.org.br>. Acesso em: 29 jul. $2014 ; 78$

Figura 14. Festa da colheita na Fazenda Quilombo, Limeira, 1909. Acervo virtual do Museu da Imigração do Estado de São Paulo. Disponível em: <http://museudaimigracao.org.br> Acesso em: 29 jul. 2014; 78

Figura 15. Indumentária dos tropeiros. Acervo do Museu de História e Folclore Maria Olímpia. Registro fotográfico da autora, 2013; 79

Figura 16. Forno a lenha e utensílios domésticos. Acervo do Museu de História e Folclore Maria Olímpia. Registro fotográfico da autora, 2013; 79

Figura 17. Interior da Casa do Caipira. Fazenda Chocolate, Itu. Registro fotográfico da autora, 2014; 80 
Figura 18. Compadre Timóteo passando café. Faz. Chocolate, Itu. Registro fotográfico da autora, 2014; 80

Figura 19. Simplicidade nos objetos de serviço. Coleção de Bens Móveis Históricos do Solar da Marquesa de Santos, São Paulo. Registro fotográfico da autora, 2014; 81

Figura 20. Objetos ricamente decorados, símbolo de status. Coleção de Bens Móveis Históricos do Solar da Marquesa de Santos, São Paulo. Registro fotográfico da autora, 2014; 81

Figura 21. "Spergola". Acervo do Centro Histórico-Cultural de Santa Olímpia, Piracicaba. Registro fotográfico da autora, 2014; 82

Figura 22. "Brustolin de focolare". Acervo do Centro Histórico-Cultural de Santa Olímpia, Piracicaba. Registro fotográfico da autora, 2014; 82

Figura 23. Porcelanas vindas da Europa. Exposição Modos de morar dos paulistas: 1840-1940, Espaço Cultural Engep, Limeira. Registro fotográfico da autora, 2014; 83

Figura 24. Retratos de parede e móveis de palinha. Exposição Modos de morar dos paulistas: 1840-1940, Espaço Cultural Engep, Limeira. Registro fotográfico da autora, 2014; 83

Figura 25. Religiosidade no ambiente doméstico. Exposição Modos de morar dos paulistas: 1840-1940, Espaço Cultural Engep, Limeira. Registro fotográfico da autora, 2014; 83

Figura 26. Apetrechos domésticos de serviço. Exposição Modos de morar dos paulistas: 1840-1940, Espaço Cultural Engep, Limeira. Registro fotográfico da autora, 2014; 83

Figura 27. Mapa do avanço do café. (Reproduzido de HOLLOWAY, 1984, p. 64); 90

Figura 28. Distribuição das visitas na pesquisa de campo. Elaborado pela autora em 2014; 90

Figura 29. Panela de ferro para preparo diário de alimentos. Botucatu. Foto: Eliete Soares, 2014; 122

Figura 30. Pilão com semente de urucum para preparo do Colorau. Laranjal Paulista. Foto: Eliete Soares, 2014; 123

Figura 31. Pilão utilizado como enfeite por não estar em uso. Botucatu. Foto: Eliete Soares, 2014; 123

Figura 32. Pilão fora de uso acomoda objetos diversos. Laranjal Paulista. Foto: Eliete Soares, 2014; 123

Figura 33. Altar doméstico com imagens de santos, flores e fotografias de parentes falecidos. Laranjal Paulista. Foto: Eliete Soares, 2014; 124

Figura 34. Bíblia no suporte sobre a cômoda no quarto: funcionalidade e preocupação estética. Piracicaba. Registro fotográfico da autora, 2014; 124

Figura 35. O passado no sítio materializado: moedor de carne guardado como relíquia. Monte Aprazível. Registro fotográfico da autora, 2014; 124

Figura 36. Vassoura de palha nova. Piracicaba. Registro fotográfico da autora, 2014; 127

Figura 37. Vassoura de palha usada, com formato arredondado pelo uso. Limeira. Registro fotográfico da autora, 2014; 127

Figura 38. Máquina de costura em uso. Campinas. Registro fotográfico da autora, 2014; 128 
Figura 39. Coador de pano feito pela moradora a partir de sobras de tecido. Monte Aprazível. Registro fotográfico da autora, 2014; 129

Figura 40. Fogão a lenha. Laranjal Paulista. Foto: Eliete Soares, 2014; 130

Figura 41. Tacho de cobre para fazer sabão de cinzas. Monte Aprazível. Registro da autora, 2014; 130

Figura 42. Copo "bico de jaca" para as visitas. Piracicaba. Registro fotográfico da autora, 2014; 131

Figura 43. Prato de porcelana industrializado desmerece a coleção. São Luís do Paraitinga. Registro fotográfico da autora, 2014; 131 


\section{Lista de Gráficos}

Gráfico 1. Imigração na província de São Paulo (1880-1900). Elaborado pela autora em 2015 (dados extraídos de VASCONCELOS, 1994, p. 227); 47

Gráfico 2. Temas dos trabalhos apresentados no XVI Congresso Brasileiro de Folclore, 2013. Elaborado pela autora em 2015; 60

Gráfico 3. Matéria-prima dos artefatos. Elaborado pela autora, 2015; 117

Gráfico 4. Aspectos da composição formal. Elaborado pela autora, 2015; 118

Gráfico 5. Função do artefato na casa. Elaborado pela autora, 2015; 122

Gráfico 6. Aspectos de usabilidade. Elaborado pela autora, 2015; 126

Gráfico 7. Aspectos de ergonomia. Elaborado pela autora, 2015; 126

Gráfico 8. Origem do artefato. Elaborado pela autora, 2015; 128

Gráfico 9. Aspectos relacionados ao significado dos artefatos. Elaborado pela autora, 2015; 129 


\section{Lista de Tabelas}

Tabela 1. Lista dos 58 artefatos típicos sugeridos. Elaborada pela autora em 2014; 85

Tabela 2. Ascendência e idade dos entrevistados. Elaborada pela autora em 2014; 86

Tabela 3. Lista dos 35 artefatos presentes nos relatos de memória. Elaborada pela autora em 2014; 88

Tabela 4. Lista dos 77 artefatos memoráveis. Elaborada pela autora em 2014; 89

Tabela 5. Idade, local de residência e ascendência dos respondentes. Elaborada pela autora em 2014; 91

Tabela 6. Ocorrência dos artefatos na pesquisa de campo. Elaborada pela autora em 2014; 93

Tabela 7. Critérios para a análise dos artefatos. Elaborada pela autora em 2014; 97

Tabela 8. Ficha de análise da dimensão percepção. Elaborada pela autora em 2014; 102-103

Tabela 9. Ficha de análise da dimensão percepção, para as categorias cores e padrões. Elaborada pela autora em 2014; 104-105

Tabela 10. Ficha de análise da dimensão uso. Elaborada pela autora em 2014; 106-107

Tabela 11. Ficha de análise da dimensão significado. Elaborada pela autora em 2014; 108-109

Tabela 12. Ficha de análise da forma de aquisição. Elaborada pela autora em 2014; 110-111 


\section{Lista de Quadros}

Quadro 1. Representações do universo caipira nas telas do pintor Almeida Júnior. Acervo da Pinacoteca do Estado de São Paulo. Registro fotográfico da autora, 2013.

Da esquerda para a direita e de cima para baixo: O violeiro (1899), Amolação interrompida (1894), Apertando o lombilho (1895), Estudo para cabeça de caipira (1893), Caipira picando fumo (1893), Cozinha caipira (1895); 77

Quadro 2. Artefatos que apresentam simplicidade formal. Registros fotográficos da autora, 2014 (à exceção do pilão, foto: Eliete Soares).

Da esquerda para a direita e de cima para baixo: caneca da ágata, Laranjal Paulista; peneira de grãos, Limeira; bacia de alumínio, Limeira; caneca de alumínio, Botucatu; vassoura de palha, Monte Aprazível; pilão de madeira, Botucatu; tacho de cobre, Monte Aprazível; 119

Quadro 3. Artefatos que apresentam complexidade formal. Registros fotográficos da autora (à exceção do quadro de madeira, foto: Eliete Soares), 2014.

Da esquerda para a direita e de cima para baixo: vaso de porcelana com flores artificiais sobre toalhinha de crochê, Piracicaba; pote de balas decorado com fitas e apliques, São Luís de Paraitinga; cortina de renda, Rio Claro; pano de prato pintado à mão com apliques de crochê, Piracicaba; vaso com flores secas, jarra de leite e outros bibelôs, Botucatu; flores, enfeites, imagens de santos em pequeno altar, Botucatu; quadro de madeira com imagens de santos e relógio, Botucatu; 119

Quadro 4. Paleta de tons vibrantes e contrastantes presentes em determinados artefatos. Registros fotográficos da autora, 2014.

Da esquerda para a direita e de cima para baixo: paleta de cores extraídas das imagens (produzida pela autora); tapete de retalhos, Laranjal Paulista; vasos com flores artificiais, Piracicaba; estandarte do Divino Espírito Santo; São Luís do Paraitinga; toalhas de plástico, Laranjal Paulista; colcha de crochê e imagens de santos sobre toalha bordada, Piracicaba; relicário de Santo Antônio, Monte Aprazível; 120

Quadro 5. Paleta de tons esmaecidos, cores desbotadas pelo tempo presentes em deter-minados artefatos. Registros fotográficos da autora, 2014 (à exceção da cadeira de balan-ço, foto: Eliete Soares).

Da esquerda para a direita e de cima para baixo: paleta de cores extraídas das imagens (produzida pela autora); tapetinho de retalhos, Laranjal Paulista; imagens de santos, Laranjal Paulista; toalha de plástico, Laranjal Paulista; tigela de porcelana, Limeira; cadeira de balanço com almofada de retalho, Laranjal Paulista; imagem de Santa Bárbara e imagem de São Sebastião, Piracicaba; colcha de retalho, Botucatu; 121 
Quadro 6. Toalhinhas e guardanapos protegem objetos e móveis. Registros fotográficos da autora, 2014 (à exceção do paneleiro, foto: Eliete Soares).

Da esquerda para a direita e de cima para baixo: toalhinha cobre as prateleiras, Laranjal Paulista; pano de prato sobre a geladeira, Rio Claro; prateleiras do paneleiro cobertas com guardanapos bordados, Botucatu; cobre talha, Campinas; toalha de crochê sobre o fogão, Piracicaba; crochê protege a gaiola e o botijão de gás, Piracicaba; 125 

Sumário

Introdução 29

Capítulo 1 . Design, identidade, memória e folclore 41

1.1 Breve panorama histórico da formação da sociedade em São Paulo 44

1.2 Cultura caipira 49

1.3 Folclore, mercantilização e inter-relações culturais 55

1.4 Identidade, memórias afetivas e objetos do cotidiano 64

1.5 As questões da identidade na prática do design $\quad 69$

Capítulo 2. Métodos para investigação da cultura visual e material caipira 73

2.1 Contextualização do universo material 75

2.2 Identificação, localização, análise e confronto dos artefatos 84

Capítulo 3. Resultados 115

Conclusões 135

Referências bibliográficas 141

Apêndices e anexos 149 

Introdução 

Os artefatos são símbolos de uma cultura, carregam significados atribuídos a eles por um determinado grupo de pessoas num dado contexto histórico e sociocultural. Estudar suas características, bem como seus significados, é uma maneira de se compreender os valores, costumes e tradições daquele grupo.

O design, por meio de seus produtos, tem o poder de influenciar diretamente a construção da cultura de um determinado povo. Paradoxalmente, quando se trata de culturas populares, muitos de seus artefatos, resultado de criações anônimas de design espontâneo, apresentam-se como uma forma de resistência dos valores culturais daquele grupo frente a uma situação de submissão econômica e social.

Em tempos de acelerada globalização e consequente crise de identidade por que passa o sujeito pósmoderno, acredita-se pertinente o olhar científico da pesquisa em design sobre manifestações de design vernacular, no sentido de se estabelecer um possível elo entre o design de artefatos e os processos de identificação cultural.

Seguindo este pressuposto, o objeto deste estudo são artefatos domésticos de uso cotidiano encontrados em residências de famílias modestas de origem rural, no estado de São Paulo nos dias atuais. Ou seja, objetos que, embora ordinários, representam a tradicionalidade do povo paulista na medida em que habitam não somente as casas da camada subalterna desta sociedade, descendente de sitiantes, caipiras e colonos, mas também as memórias de grande parte da população adulta paulista, onde quer que ela se encontre, cujas vivências da infância ocorreram neste contexto na segunda metade do século XX.

Entendendo o folclore como uma disciplina que estuda os produtos da mentalidade popular e compreendendo a presença e a maneira de dispor estes objetos no ambiente doméstico, assim como o saber utilizá-los, um resultado da mentalidade destes indivíduos, esta pesquisa pode ser considerada um estudo de folclore com enfoque no design de artefatos, especificamente no que diz respeito a suas características estéticas e funcionais, bem como seus significados.

Tendo-se em conta estudos da cultura material' que advogam "a noção de que os povos e as sociedades se dão a conhecer através dos artefatos que produzem" (CARDOSO, 1998, p. 37), estudar estes objetos é uma maneira de se investigar aspectos da formação da sociedade no estado de São Paulo, eminentemente rural, com a qual se identifica grande parte da população paulista adulta nos dias atuais. Suas memórias afetivas frequentemente guardam lembranças de tempos na casa da avó, férias com os primos do interior, reuniões em volta da mesa da cozinha com cheiro de fogão a lenha, chupar jabuticaba no pé. Essas memórias constituem sua identidade e são elas que nos indicam o caminho para esta pesquisa acerca da cultura material popular paulista e suas tradições.

Este trabalho segue a abordagem proposta por um dos pioneiros nos estudos em folclore, Amadeu Amaral (1921), que defendia que os significados dos fatos folclóricos só poderiam ser compreendidos quando fossem estudados mergulhados em seu contexto sociocultural.

Amaral, poeta e escritor, discursa em abril de 1925 na Academia Brasileira de Letras pela criação de uma associação folclórica (ou demológica) de São Paulo; propõe o estudo das tradições populares e, como colunista do jornal O Estado de São Paulo, nas décadas de 1920 e 1930, publica uma série de artigos sobre a relevância do estudo e da preservação da memória popular do povo de São Paulo; defende a necessidade 
da sistematização dos estudos do folclore, desde o levantamento dos aspectos considerados característicos de uma determinada manifestação até sua análise, sempre a partir da contextualização, do evento popular, seja ele uma dança ou a produção de um determinado artefato. Amaral dizia que "essas tradições são a melhor porção do protoplasma espiritual em que se modela a consciência do povo [...] porque são partículas sagradas da própria essência da nacionalidade, da alma da pátria" (AMARAL,1921, p. 7).

Seu interesse particular era o modo de falar do paulista que, em sua opinião, era distinto e inconfundível. Na década de 1920, desenvolve O Dialeto Caipira, um estudo do vocabulário, da sintaxe, da morfologia e da prosódia do caipira que, para ele, estavam em vias de serem extintos em função do avanço da modernidade e da urbanidade. Amaral passou boa parte de sua vida associando os estudos do folclore à formação de uma identidade regional. Da mesma forma, nosso interesse também reside na possibilidade de uma identidade regional, só que por meio do artefato e não do dialeto.

Quase um século depois de Amaral publicar seus primeiros artigos sobre a tradição popular dos paulistas, ainda é possível encontrar a identidade regional chamada pelo autor de "o caipirismo do estado de São Paulo, acantoado em pequenas localidades" (AMARAL, 1955) habitando a roça, as vilas e ruas tranquilas das cidades do interior, ou mesmo as bordas imprecisas dos subúrbios das grandes cidades.

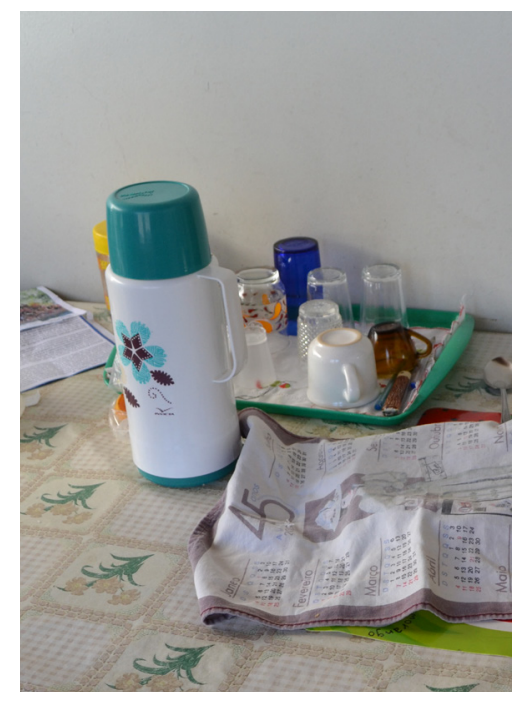

Figura 1. Toalha de plástico e café na garrafa térmica, Monte Aprazível, 2014. Registro fotográfico da autora, 2014.

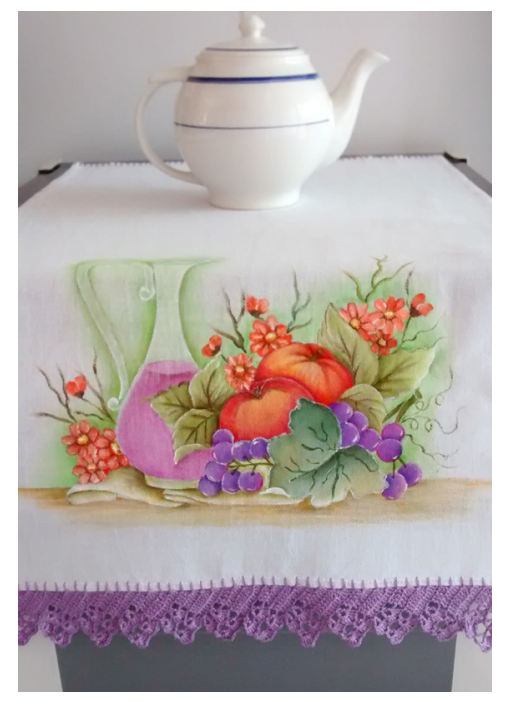

Figura 2. Pano de prato pintado à mão, Campinas, 2014. Registro fotográfico da autora, 2014.

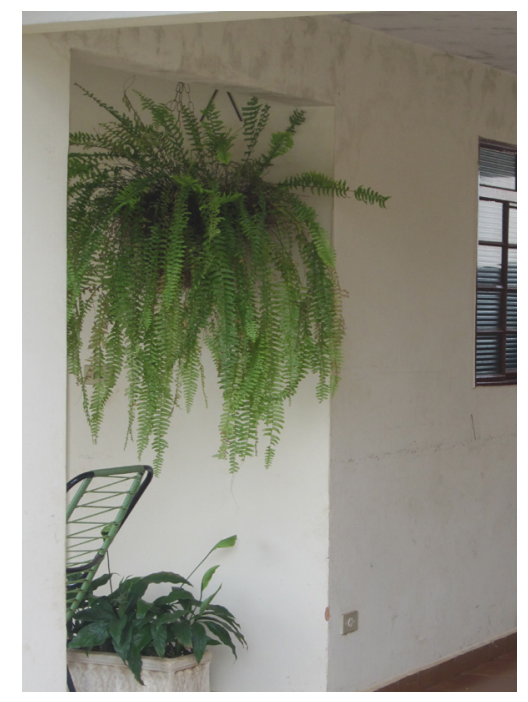

Figura 3. Vasos com samambaias pendurados na garagem, Monte Aprazível, 2014. Registro fotográfico da autora, 2014.

Bata na casa daquela senhora de vestido florido, a casa verde água de portão branco. Certamente ela vai Ihe oferecer um café. Ao entrar, irá se desculpar por alguma desordem a caminho da cozinha onde haverá uma mesa coberta por uma toalha de plástico florida e a garrafa térmica à espera de um dedo de prosa (Figura 1); sobre o fogão, um pano de prato com flores pintadas à mão e bico de crochê anuncia o fim das atividades do almoço (Figura 2). Ao se despedir, não deixe de elogiar as plantas penduradas na garagem, especialmente as samambaias, orgulho da dona da casa (Figura 3).

Este ambiente, seus objetos e a maneira como as pessoas se relacionam com eles nos interessam como representação da identidade de uma parte específica da identidade brasileira que chamamos de caipira. Trata-se de um cenário repleto de artefatos que podem ser compreendidos como uma forma de resistência da cultura popular. Não estamos nos referindo "a ações deliberadas de resistência [...] mas a práticas dotadas de uma lógica que os transforma em atos de resistência" (CHAUÍ, 1986, p.63). Estes artefatos são 
signos de uma cultura que sobrevive, ora sobrepujando, ora se adaptando, a fatores sociais e históricos desde o desbravamento do território paulista pelos bandeirantes portugueses com o aprisionamento de indígenas no século XVII e XVIII, à libertação dos escravos no final do século XIX e à chegada de imigrantes estrangeiros, sobretudo italianos, para trabalhar nas fazendas de café, ao rápido crescimento da população nas primeiras décadas do século XX, à industrialização, à ampliação das vias de comunicação e de comércio, e ao incremento da educação (CASTRO, 2006). Na segunda metade do século XX, a cultura caipira viu-se diante da alteração na dinâmica econômica do chamado mercado globalizado e na aceleração das trocas comerciais e culturais amplificada pelo fenômeno das telecomunicações e da informática. Neste contexto, observam-se não só os processos produtivos que privilegiam a produção em larga escala, mas também uma homogeneização das referências estéticas a fim de se atingir a quantidade necessária de mercados consumidores.

Com efeito, se considerarmos que um dos pressupostos para a sustentação do mundo globalizado é a quantidade: quantidade de recursos financeiros, quantidade de produtos, quantidade de usuários, quantidade de regiões a serem atingidas pelo comércio internacional e consequentemente, quantidade de trocas econômicas, vamos entender porque as formas artesanais de expressão deixam de ocupar um lugar estratégico (ESCOREL, 2000, p. 34).

Aquele caipira originário dos bairros rurais a que se refere Candido (1987) está aberto aos vetores de força da economia globalizada e seus padrões culturais.

Neste cenário situa-se a relevância de uma pesquisa no campo do design que, além de contribuir para os estudos da cultura material, possa caracterizar uma identidade regional do objeto popular nos dias de hoje: a identidade paulista, ou, abstraindo-se os estereótipos relacionados ao termo no imaginário social, a identidade caipira.

A abordagem em uma escala regional se faz necessária em função da complexidade da discussão sobre identidade cultural num país de dimensões continentais e formação social resultante da miscigenação de diferentes povos e etnias. Deste modo, este estudo localiza-se no estado de São Paulo, e refere-se a uma sociedade historicamente rural, mesmo que hoje a maioria de sua população viva nas cidades.

Ainda que este trabalho se situe no tempo presente, quando se trata de identidade é necessário mirarmos o passado para compreendermos o presente. O passado do estado de São Paulo até a década de 1950 é essencialmente rural, ou seja, a maioria da população vivia nas fazendas, sítios e bairros rurais (DE QUEIROZ, 1973). Neste contexto, interessa-nos a classe subalterna desta sociedade rural, oriunda em sua maior parte do amálgama de dois grupos a princípio distintos: o caipira, originariamente descendentes da miscigenação do português com o índio no período colonial; e o imigrante, sobretudo o italiano, que vem para São Paulo trabalhar nas lavouras de café no início do século XX.

Deste modo, esta é uma pesquisa descritiva e analítica sobre parte da materialidade da cultura popular no interior do estado de São Paulo e, para tanto, elegeu-se uma classe de objetos pouco abordada nos estudos tradicionais do folclore: utensílios domésticos comuns, objetos ordinários tradicionalmente sem valor, artefatos do cotidiano encontrados nas residências modestas de famílias de origem rural. 


\section{Objetivos}

O objetivo deste trabalho é contribuir para os estudos da cultura material brasileira em relação à possibilidade da existência de identidades regionais do objeto brasileiro popular, sob a ótica do design, através do estudo semiótico de um número determinado de artefatos domésticos memoráveis e notáveis encontrados em residências de pessoas idosas de origem rural no interior do estado de São Paulo nos dias atuais.

Para tanto, foram definidos os seguintes objetivos específicos: a) identificar um número determinado de artefatos domésticos memoráveis recorrentes, isto é, que façam parte dos relatos de memória de pessoas adultas cujas vivências afetivas da infância se deram em residências de familiares de origem rural no interior do estado de São Paulo entre as décadas de 1950 e 1990 e que possam ser considerados característicos deste contexto sociocultural; b) identificar os artefatos domésticos memoráveis em residências de pessoas idosas de origem rural no interior do estado de São Paulo, bem como o modo de dispô-los no ambiente, nos dias atuais, de forma a caracterizar o que chamaremos de objetos notáveis; c) caracterizar os artefatos domésticos considerados memoráveis e notáveis quanto a aspectos de uso, percepção e significado; d) criar um glossário visual para consulta e referência de designers com interesse na identidade regional paulista do objeto doméstico popular.

\section{Abordagem metodológica e fases da pesquisa}

Esta é uma pesquisa qualitativa de natureza teórica na modalidade etnográfica, mas com um acentuado caráter fenomenológico, uma vez que sua questão central é a possibilidade de uma identidade regional do objeto popular, ou seja, a identificação de um possível padrão cultural. Entretanto, seu enfoque é semiótico, uma vez que, partindo das relações de pessoas com artefatos presentes em suas memórias afetivas, investiga os significados destes objetos para um determinado número de pessoas nos dias atuais em um dado contexto, bem como seus aspectos formais e funcionais.

A pesquisa se desenvolveu em sete fases distintas, descritas a seguir.

\section{Fase I. Conceituação teórica}

A primeira fase da pesquisa consistiu em uma pesquisa bibliográfica sobre os principais conceitos teóricos do projeto - tais como identidade cultural, cultura popular e folclore, bem como a relação da memória com os objetos -, de modo a fundamentá-lo.

\section{Fase II. Contextualização histórico-social}

Nesta fase deu-se a contextualização histórico-social e a caracterização do ambiente onde a pesquisa está inserida, ou seja, o estado de São Paulo, seu processo de povoamento, as particularidades de sua origem 
rural - com a figura do caipira e dos imigrantes - e a formação da sociedade nesta região. Para auxiliar na caracterização da cultura material rural de São Paulo, nas últimas décadas do século XIX e primeiras décadas do século $X X$, foi realizada uma pesquisa documental de obras de reconhecido teor regionalista, romances e livros de contos de autores consagrados. Para fornecer subsídios visuais de caracterização do universo material da época citada foram feitas pesquisas iconográficas por meio da análise de obras de arte, visitas a museus e exposições de objetos do período citado.

\section{Fase III. Identificação dos objetos memoráveis}

Após a contextualização da pesquisa, a etapa seguinte consistiu em identificar o objeto de estudo a partir do cruzamento de três parâmetros: primeiramente, tratam-se de objetos populares, uma vez que representam a cultura popular em oposição à cultura erudita, ou ainda por serem representativos da camada subalterna da sociedade rural paulista, ou seja, famílias de origem rural formadas por pequenos proprietários de terra brasileiros, descendentes de portugueses, índios, colonos imigrantes ou mesmo, ainda que em menor número, escravos; em segundo lugar, são artefatos memoráveis, ou seja, que participam da memória afetiva de uma determinada parcela da população adulta paulista nos dias atuais, cujas famílias se enquadram na definição acima; e em terceiro, são objetos ordinários que fazem parte da vida privada e cotidiana de famílias com as características acima citadas, que puderam ser encontrados em visitas às residências durante a pesquisa de campo.

Para identificarmos um número significativo de utensílios considerados memoráveis foram utilizados depoimentos informais e entrevistas temáticas semiestruturadas com indivíduos paulistas adultos, entre 27 e 58 anos de idade, de família de origem rural e condição socioeconômica pertinente ao caráter popular da pesquisa, previamente selecionados através de um questionário, indagados sobre as memórias afetivas da infância em casa de parentes no interior do estado, bem como os objetos presentes nestas lembranças e os significados atribuídos a estes, o que permitiu sua caracterização do ponto de vista simbólico. O resultado ao final desta fase foi uma lista de artefatos memoráveis característicos a serem localizados na fase seguinte.

\section{Fase IV. Localização dos artefatos notáveis}

Esta fase consistiu na busca pelos artefatos memoráveis in loco. Sendo assim, verificou-se a ocorrência dos objetos memoráveis de modo que, ao seu final, fosse possível elencar uma lista de artefatos domésticos típicos da cultura popular paulista, que foram chamados de artefatos notáveis. Para tanto, foi executada uma pesquisa de campo a residências de paulistas idosos, com idade entre 60 e 97 anos, de origem familiar rural e condição social circunscrita ao contexto da pesquisa. Foram feitos registros fotográficos destes objetos, bem como do modo de dispô-los no ambiente doméstico, além de colhidos depoimento dos moradores a respeito de sua história pessoal e de sua relação com aqueles utensílios, fazendo uso de gravações em áudio e anotações diretas. Ao final da pesquisa de campo elaborou-se um acervo do que chamamos de artefatos notáveis, isto é, aqueles objetos memoráveis localizados, que se pôde notar e identificar. 


\section{Fase V. Análises dos artefatos}

Esta etapa correspondeu às análises dos artefatos de acordo com os dados coletados na pesquisa de campo. Uma vez que este estudo tem um enfoque semiótico, considera os objetos de uso cotidiano como signos de uma cultura. Foram definidos, de acordo com autores da semiótica e do design ${ }^{2}$, aspectos relativos à percepção, uso e significado dos objetos que deveriam ser investigados. Deste modo, acreditamos ter sido possível observar de forma sistemática e abrangente o objeto em si, sua materialidade, sua composição como um todo e as partes que o compõem, seus detalhes visuais e construtivos, bem como as relações destes artefatos com seus usuários, tanto operacionais, isto é, relativas à sua funcionalidade, quanto simbólicas, o que compreende os significados atribuídos aos objetos pelos indivíduos.

\section{Fase VI. Confrontação}

De posse de imagens fotográficas dos artefatos notáveis encontrados na pesquisa de campo, voltamos aos adultos respondentes cujas memórias de infância constituíram a base para a pesquisa, a fim de confrontar as imagens capturadas com suas lembranças. O resultado deste confronto fala muito sobre a relação dos indivíduos com suas origens e sua identidade, bem como sobre inter-relações culturais.

\section{Fase VII. Discussão dos resultados}

Finalmente a sétima e última fase do trabalho compreende a discussão dos resultados obtidos nas análises. Foram agrupados os achados das análises de acordo com possíveis padrões de semelhança em relação aos atributos investigados de modo a configurar aspectos da linguagem destes objetos, objetivo central do trabalho. Além de identificar semelhanças, foi possível revelar particularidades de ocorrências individuais, compreendendo-se que uma determinada identidade também possa se caracterizar por meio de diferentes unicidades.

\section{Definição de termos fundamentais empregados na pesquisa}

Este estudo considera equivalentes os termos folclore e cultura popular ${ }^{3}$, de acordo com a definição do Centro Nacional de Folclore e Cultura Popular do Ministério da Cultura, consonante com o que preconiza a UNESCO, e também Arantes (1982) e Brandão (1982). Algumas particularidades sobre os dois termos são abordadas no Capitulo 1, item 1.3, Folclore, mercantilização e inter-relações culturais.

Baseando-se na definição de que "objetos feitos ou modificados por seres humanos podem ser agrupados sob o termo artefato" (PROWN, 1993, p. 2, tradução nossa), optou-se pelo uso do termo artefato para se referir aos objetos de estudo. Mesmo quando se trata de um objeto natural como uma samambaia,

2 Do ponto de vista da semiótica baseamo-nos em Morris (1970) e Bense (1971). Sob a ótica da psicologia cognitiva, apoiamo-nos nos estudos em design emocional de Norman (2008). Para compreendermos as funções do design de objetos na interação homem-objeto, utilizamos o pressuposto por Lobach (1981).

3 CENTRO Nacional de Folclore e Cultura Popular (CNFCP). Disponível em: <http://www.cnfcp.gov.br>. Acesso em: 2 jul. de 2013. 
por exemplo, este estudo considera-o como um artefato uma vez que a samambaia aqui citada não se apresenta em sua forma selvagem em meio à natureza, mas sim modificada e resignificada pela ação humana, interesse central da pesquisa.

Para fins metodológicos, utilizamos os termos artefatos memoráveis e artefatos notáveis como diferenciação em função das fases da pesquisa.

Por artefatos memoráveis compreende-se objetos "que fazem bem lembrar" (DAMAZIO, 2013, p. 43), presentes nas memórias afetivas de vivência da infância relatadas em entrevistas e depoimentos espontâneos na fase de identificação do objeto de pesquisa. Neste sentido, esta pesquisa se aproxima de Damazio, que utiliza o termo artefatos de memória ao investigar as características das coisas que fazem bem lembrar:

as coisas que fazem bem lembrar se apresentavam como uma curiosa classe de artefatos que se destacavam por sua capacidade de promover ações, como divertir, enternecer, confortar, fortalecer, encorajar, entre outras de ordem emocional e possivelmente não planejadas por seus criadores (DAMAZIO, 2013, p. 43).

O termo artefatos notáveis foi empregado para caracterizar aqueles artefatos memoráveis notados, ou seja, localizados, identificados e registrados em residências modestas de pessoas idosas em cidades de tradição rural no interior do estado de São Paulo, na fase da pesquisa de campo.

\section{Delimitação da pesquisa}

A primeira delimitação deste trabalho é com relação a sua natureza, uma vez que não se trata de uma pesquisa histórica, e tampouco os objetos aqui estudados são analisados como objetos históricos.

Os artefatos aqui estudados não participaram de fatos históricos pontuais, mas sim de memórias individuais coletivizadas da vida cotidiana de parte de uma população. Assim, não se encaixam na descrição de objeto histórico como aquele "caracterizado por sentido prévio e imutável que o impregna [...] pela contaminação externa com alguma realidade transcendental - por exemplo a vinculação a fatos memoráveis da história do Brasil" (MENESES, 1998, p. 93), cuja procedência é tema de estudo e relevância na história da cultura material. Ainda segundo Meneses, os objetos históricos são

objetos singulares e auráticos, na expressão benjaminiana ou, mais precisamente, não-fungíveis, [...] que não poderiam ser substituídos por cópias ou por objetos de atributos equivalentes. São excluídos de circulação e não só têm seu valor de uso drenado, como trazem para qualquer uso prático eventual a pecha do sacrilégio (MENESES, 1998, p. 93).

Os objetos aqui estudados, pelo contrário, são ordinários em circulação e uso, mas que ainda assim carregam um significado para quem os guarda na memória. Copiados, reutilizados ou resignificados, estes objetos seguem o conceito de tradicionalidade, que se compreende por meio da noção de continuidade, "onde os fatos novos se inserem sem uma ruptura com o passado, mas que se constroem sobre esse passado" (BENJAMIN, 2011, p. 2).

A segunda delimitação diz respeito ao recorte sociocultural da pesquisa, que se dá por meio da cultura caipira, pois se trata de investigação sobre a identidade paulista. Baseamo-nos na premissa de que, mesmo permeada dentro dos grandes centros urbanos, ainda somos uma sociedade caipira, na medida em que certos hábitos, certas tradições, permanecem. 
Vistas dessa perspectiva, numa abordagem histórica e significativa, as práticas culturais do caipira se aproximam muito mais daquelas dos paulistas de hoje. Deixam de ser uma imagem isolada, literária, preconceituosa, ou simplesmente rural, porque integram inúmeros pontos de identidade e cultura e desconstroem uma modernidade que nunca existiu de modo integral (SETUBAL, 2004, p. 43).

Éimportante pontuar que, atéa década de 1950, a população do estado de São Paulo vivia predominantemente em áreas rurais e a fronteira entre o urbano e o rural não aparece claramente quando se trata de cultura popular. Deste modo, o recorte se dá pela natureza social e não geográfica. Entretanto, uma vez que a pesquisa se baseia no passado rural do povo paulista, não abarca as famílias cuja tradição está ligada à industrialização do estado, como por exemplo, imigrantes italianos ou judeus que vieram trabalhar nas fábricas em São Paulo, no começo do século XX.

Em relação ao recorte temporal, a pesquisa divide-se em duas épocas distintas: a primeira concentra-se na segunda metade do século passado, entre as décadas de 1950 e 1990 com os relatos de memória de vivências da infância dos entrevistados; a segunda situa-se no momento presente com a busca da identidade por meio da cultura material nos dias atuais.

\section{Estrutura da dissertação}

Esta dissertação está dividida em três capítulos: (1) "Design, identidade, memória e folclore"; (2) "Métodos para investigação da cultura visual e material caipira" e (3) "Resultados", sendo que cada capítulo está subdividido em seções como descrito a seguir.

O primeiro capítulo, intitulado "Design, identidade, memória e folclore", apresenta a revisão da literatura selecionada pertinente aos conceitos discutidos na pesquisa, bem como contextualiza o objeto de estudo em seu universo histórico e social. Divide-se em cinco seções:

A seção 1.1, "Breve panorama histórico da formação da sociedade em São Paulo", apresenta um breve histórico da formação da sociedade paulista desde a colonização, considerando seu povoamento enquanto uma das mais pobres capitanias, as bandeiras de aprisionamento de indígenas e a questão do nomadismo de sua população, embrião da cultura caipira. Avança para a expansão da economia cafeeira no final do século XIX, a crise da mão de obra após a libertação dos escravos e a chegada dos imigrantes para trabalhar nas lavouras de café do interior do estado, abordando a questão da miscigenação da cultura imigrante com a cultura caipira aqui instalada.

A seção 1.2, "Cultura caipira" aborda o termo 'caipira', seu significado, sua conotação historicamente pejorativa e sua compreensão por autores da sociologia e da antropologia a fim de caracterizar o contexto sociocultural no qual está situada a pesquisa.

A seção 1.3, "Folclore, mercantilização e inter-relações culturais" apresenta um breve panorama sobre os estudos do folclore e da cultura popular no Brasil de modo a conceituar o termo folclore por meio de autores consagrados no campo; discute a questão da materialidade nos estudos em folclore, especificamente a cultura material do cotidiano, e levanta as imbricações presentes nas inter-relações entre diferentes formas de cultura. 
A seção 1.4, intitulada "Identidade, memórias afetivas e objetos do cotidiano", apresenta a relação entre os objetos do cotidiano e seu papel nas vivências afetivas e nos relatos de memória, bem como sua relevância na construção da identidade.

Finalmente, a seção 1.5, "As questões da identidade na prática do design", discorre sobre a atualidade do tema "identidade" no exercício do design no Brasil, voltando à década de 1960 com Aloísio Magalhaes e Lina Bo Bardi, até os dias atuais, considerando, por exemplo, os trabalhos expostos na $9^{a}$ Bienal de Design Gráfico da ADG/Brasil (Associação dos Designers Gráficos do Brasil), em 2009, ou ainda os programas desenvolvidos por instituições como o Sebrae (Serviço Brasileiro de Apoio às Micro e Pequenas Empresas), Abexa (Associação Brasileira de Exportação de Artesanato) e Apex-Brasil (Agência Brasileira de Promoção de Exportações e Investimentos), unindo artesanato, design e identidade.

O segundo capítulo, intitulado "Métodos para investigação da cultura visual e material caipira" discorre sobre os métodos utilizados na pesquisa em suas respectivas etapas. Está dividido em três seções.

A seção 2.1, intitulada "Contextualização do universo material" apresenta os métodos empregados bem como os dados primários e secundários obtidos na pesquisa, utilizados para a contextualização do universo material deste trabalho. Compreende uma pesquisa bibliográfica acerca da materialidade presente nas histórias e representações narradas no ambiente rural de São Paulo nas últimas décadas do século XIX e primeiras décadas do século XX, citado em obras de reconhecido teor regionalista, romances e livros de contos. Inclui também um levantamento iconográfico feito para caracterizar o universo caipira - bem como dos imigrantes que vieram ao país trabalhar nas fazendas paulistas como colonos-, feito por meio de visitas a museus e exposições, bem como a análise de obras de arte e literatura da época pertinentes ao contexto da pesquisa.

A seção 2.2, intitulada "Identificação, localização, análise e confronto dos artefatos", discorre sobre os métodos empregados e os respectivos dados levantados nas fases da pesquisa correspondentes à identificação do objeto, sua localização em campo e posterior análise, além da fase de confrontação das imagens destes artefatos com os respondentes que deram origem à lista de objetos memoráveis. Nesta seção, é apresentada de forma detalhada cada uma das etapas, bem como seus instrumentos de pesquisa. Com relação à análise dos artefatos, a seção apresenta ainda a fundamentação teórica que embasa o procedimento de análise, a definição dos critérios a serem analisados e os instrumentos utilizados para tal.

O terceiro capítulo da dissertação intitulado "Resultados", corresponde às interpretações das análises realizadas anteriormente, gerando efetivamente o que se pode chamar de resultados da pesquisa. Inclui os achados relativos a cada uma das categorias analisadas, organizados de forma a facilitar a identificação de padrões de associação.

Finalmente, apresentam-se algumas discussões e conclusões decorrentes deste estudo. Primeiramente, discute-se a relação do design dos artefatos com a origem sociocultural da população observada, resultante de sua formação histórica, proveniente da miscigenação da cultura caipira com a dos imigrantes. Posteriormente, aponta-se um fenômeno de disparidade cultural, observado tanto do ponto de vista da linguagem plástica quanto das questões de uso e significado, entre as manifestações provenientes da cultura popular presentes nas memórias dos paulistas e notados nas residências do interior, o que mecanismos da cultura de massa disseminam como modelo. Por fim, apontam-se possíveis extensões para esta pesquisa. 
Capítulo 1

Design, identidade, memória e folclore 
Quinze anos após a fundação da Escola Superior de Desenho Industrial (ESDI), em palestra proferida no ano de 1977, Aloísio Magalhães instigou-nos a questionar o papel do design e a reconceituar a atividade no país. Analisando a história do ensino do design no Brasil naqueles quinze anos, Magalhães discorre sobre o modelo adotado pela escola afirmando que, ainda que em aparente contradição com nosso temperamento latino e tropical - chamado por ele de "natureza espontânea e intuitiva"-, sua adoção seria acertada, pois "através dele nos foi possível introduzir os componentes da razão e do método necessários à formulação de uma dialética, com a nossa quase excessiva valoração dos elementos intuitivos" (MAGALHÃES, 1998, p. 10). Ao falar sobre elementos intuitivos, Magalhães referia-se à diversidade da cultura formada por elementos oriundos da latinidade, somados à cultura indígena e posteriormente à cultura africana dos escravos, segundo ele carentes da razão e do método.

Após quinze anos de ensino do design no país, Magalhães nos propôs uma revisão conceitual no papel do design, apontando as diferenças entre as economias dos países centrais e periféricos, onde o design pudesse deixar de ser uma atividade apenas voltada à "visão imediatista e inevitavelmente consumista de produzir novos bens de consumo" para se debruçar sobre uma realidade própria, cujo "horizonte é alargado [...] pela presença de situações, formas de fazer e de usar primitivas e pré-industriais" (MAGALHÃES, 1998, p. 12). Numa clara demonstração de que não abandonara sua visão acerca dos valores culturais, Magalhães nos fez um chamado à necessidade de se reconceituar a atividade (e não só o ensino) do design, voltar à realidade do país e suas "diversidades de saberes e de situações muito distanciadas: da pedra lascada ao computador" (MAGALHÃES, 1998, p. 12).

Magalhães apontou-nos o reconhecimento dos diferentes valores culturais intrínsecos à noção de identidade cultural como um possível caminho para o design no Brasil. Desta forma, estabelecia um vínculo entre as culturas primitivas e populares (ou folclore), a noção de identidade e o design.

Quase quatro décadas após seu discurso, este caminho conceitual continua pertinente, uma vez que em muitos sentidos ainda somos uma sociedade da pedra lascada ao computador, inclusive com maior distância entre as situações às quais se referia Magalhães, devido à aceleração dos processos de globalização a que fomos submetidos no final do século XX, o que incrementou a desigualdade social no país.

A ideia de identidade se consolida como algo plural e impreciso, cujos contornos são maleáveis, assim como a própria definição de folclore, melhor entendida como uma "situação de cultura" (BRANDÃO, 1982, p. 45) do que como uma forma de cultura. Entretanto, ainda que identidade e folclore sejam conceitos imprecisos, coincidem no fato de se reescreverem a cada ocorrência, operando como mecanismos de

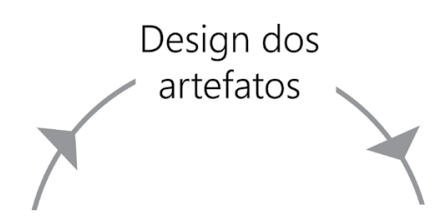

Identidade

Memórias

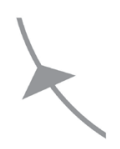

\section{Folclore}

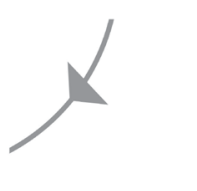

Figura 4. Diagrama conceitual que embasa o estudo. Elaborado pela pesquisadora, 2015. continuidade e coerência. Neste sentido, podemos dizer que o primeiro se deixa escrever pelo segundo, ou seja, os fatos folclóricos constituem boa parte do que se entende por identidade.

Acrescentamos, assim, a este diagrama conceitual (Figura 4) mais um elo constituído pelas nossas memórias. Contadas e recontadas em processo contínuo de criação e recriação, as memórias mantém vivo o fio condutor dos fatos folclóricos em benefício dos processos de identificação de um povo. 
Finalmente, considerando-se o design como "a fonte mais importante da maior parte da cultura material de uma sociedade" (CARDOSO, 1998, p. 22), podemos destacar a relevância de seu papel atuando ora como o gatilho que desperta as memórias que compõem os fatos folclóricos e constroem os processos de identificação, ora como a materialização das memórias recriadas nos processos de construção de identidades possíveis diante de uma situação de marginalidade vivida pelo sujeito pós-moderno.

Deste modo, os artefatos, os produtos do design, operam em nossas memórias que atuam na reconstrução dos fatos folclóricos de modo a constituir nossas identidades.

\subsection{Breve panorama histórico da formação da sociedade em São Paulo}

Para que se compreendam os hábitos e valores de um determinado povo, é preciso, antes de mais nada, voltar no tempo a fim de conhecer a história de sua formação bem como os fatos relevantes pelos quais passou aquela sociedade. Façamos então um sobrevoo pela história da formação do povo paulista, de modo a compreender suas origens e inter-relações e o que caracterizou o modo de vida das famílias de origem rural no estado de São Paulo.

O processo de povoamento do estado de São Paulo teve início ainda no século XVI com as bandeiras: expedições particulares com autorização da colônia, que partiam, em sua maioria, da vila jesuíta de São Paulo - então um pequeno e pobre povoado com cerca de 150 casas, habitadas por menos de 1.500 pessoas no planalto de Piratininga, junto ao colégio fundado por José de Anchieta.

Enquanto as cidades nordestinas, principalmente na faixa litorânea, desenvolveram-se graças ao cultivo da cana-de-açúcar, o solo pobre das terras litorâneas na capitania de São Vicente e o limite imposto pela Serra do Mar, além da relativa distância da metrópole em comparação com a capitania de Pernambuco, por exemplo, inviabilizaram a economia açucareira na região.

Diante da falta de ocupação, parte da população vicentina abandona o litoral e sobe a serra até o planalto de Piratininga. Porém, a situação de pobreza ali não é diferente. Frente a um cenário de economia de subsistência isolada do restante da colônia, jovens paulistas financiados por recursos particulares e alguma influência junto ao capitão-mor, saem em direção ao sertão, em expedições que iam desde pequenos grupos de vinte homens à busca de produtos naturais comercializáveis, chamados de drogas do sertão, como o urucum e o guaraná, e de possíveis regiões onde poderiam ser encontrados metais e pedras preciosas - conhecidas como bandeiras de prospecção -, até grandes tropas de mais de dois mil homens, com o objetivo principal de aprisionar índios para vendê-los como escravos. Com as invasões holandesas no Nordeste do país por volta de 1630, e a tomada de entrepostos africanos em Angola e São Tomé, houve uma diminuição da entrada de escravos negros na colônia, especialmente em áreas não dominadas pelos holandeses, crescendo a demanda por indígenas para o trabalho escravo (FAUSTO, 2008).

As grandes bandeiras eram formadas por um ou dois sertanistas experientes, alguns jovens brancos portugueses, vários mamelucos (mestiço de índio com branco) e centenas de índios escravizados para carregar a carga, cozinhar e proteger o grupo. A finalidade do bandeirantismo era a captura de índios para escravizá-los como mão de obra para a agricultura. Para se ter ideia da importância desta mão de obra 
na lavoura paulista do século XVII, em oito grandes fazendas de trigo, entre 1638 e 1682, havia 987 índios escravizados, entre homens, mulheres e crianças, trabalhando no plantio, colheita, moagem e transporte da farinha para o litoral, que seria vendida para vilas e cidades do litoral brasileiro, além de exportada para Portugal (MONTEIRO, 1999, p. 120).

Para tanto, o bandeirantismo de aprisionamento não se absteve de atacar missões jesuítas no interior da colônia onde já se encontrava um grande número de índios adaptados à rotina de trabalho compulsório imposta pelos missionários em seus aldeamentos. O apresamento dos índios tornou-se então uma atividade econômica de grande vulto no mercado interno e que deveria, portanto, pagar impostos, assim como, por exemplo, a extração do pau-brasil, destinando à Coroa a quinta parte dos indígenas capturados. Porém, a resistência ao aprisionamento e as batalhas com os bandeirantes, inclusive no planalto paulista, somadas à falta de incentivo da metrópole que via no mercado de escravos indígenas um negócio menos lucrativo do que o tráfico negreiro controlado pela Coroa - agora que Portugal recuperara os entrepostos de Angola e São Tomé do poderio holandês -, aliado ao alto índice de mortalidade dos indígenas por doenças contraídas dos europeus, levaram, todos estes fatores somados, ao declínio as bandeiras de apresamento de nativos.

Os bandeirantes passaram então a se concentrar na busca e exploração de riquezas naturais como o ouro e pedras preciosas, começando pelos leitos dos rios da região. Na segunda metade do século XVII receberam apoio da Coroa e assim concentraram-se na busca pelo ouro e as pedras, principalmente no sertão de Minas Gerais e Mato Grosso.

Outra modalidade de expedição toma vulto com a finalidade de combater negros e índios rebelados contra a escravidão, destruindo quilombos e capturando escravos fugidos, financiada pelos senhores de engenho e criadores de gado, num valioso negócio com os bandeirantes, conhecida como "sertanismo de contrato", que vai ultrapassar as fronteiras em direção ao sul, norte e centro-oeste do país.

Vale observar que as bandeiras, além de serem consideradas responsáveis pelo alargamento territorial e povoamento do interior do país, também contribuíram diretamente para a devastação de diversos povos nativos devido ao caráter violento de suas ações. Outra consequência direta das expedições foi a formação de uma população de mamelucos nômades espalhados pelo sertão paulista vivendo do plantio de subsistência sem a posse da terra, chamados de "caipiras".

Graças às expedições do final do século XVII e à descoberta de ouro e pedras preciosas pelos bandeirantes nas regiões de Minas gerais, Goiás e Mato Grosso, alterou-se o eixo econômico da colônia, deslocando-se seu centro político e administrativo para o Sudeste. No rastro de suas tropas de gado muar, utilizadas para o transporte de ouro e de outras mercadorias que abasteciam as regiões mineradoras, formaram-se vilas e povoações. As mulas vinham do sul com destino a Sorocaba, no interior do estado de São Paulo, onde se estabeleceu a maior feira de muar da colônia. Daqui seguiam para Minas Gerais. No trajeto da tropa até São Paulo, os tropeiros procuravam campos gerais, livres de mata fechada e rios, para atravessar com as tropas carregadas. À noite descansavam em pastos abertos ou ranchos que mais tarde deram origem a povoados e vilas (SETUBAL, 2004). A cidade de Campinas, por exemplo,

surgiu na primeira metade do século XVIII como um bairro rural da Vila de Jundiaí. Localizado nas margens de uma trilha aberta por paulistas do Planalto de Piratininga entre 1721 e 1730 (trilha que seguia em direção às recém descobertas minas dos Goiases), o povoamento do Bairro Rural do Mato Grosso teve início com a instalação de um pouso 
de tropeiros nas proximidades da Estrada dos Goiases. O pouso das Campinas do Mato Grosso (erguido em meio a pequenos descampados ou campinhos, em uma região de mata fechada) impulsionou o desenvolvimento de várias atividades de abastecimento e promoveu uma maior concentração populacional, reunindo-se neste bairro rural em 1767, 185 pessoas (PREFEITURA MUNICIPAL DE CAMPINAS, s/d.).

Após a independência do Brasil, em 1822, inicia-se o período Imperial. O eixo econômico do país passa a se concentrar no Sudeste, especialmente nos estados do Rio de Janeiro e São Paulo. Por volta de 1840, o café se espalhara pelo Vale do Paraíba vindo do Rio de Janeiro, onde já era cultivado de modo quase artesanal. Entre 1830 e 1870, o Vale do Paraíba, fluminense e paulista, tornou-se o maior produtor de café, responsável por 78\% da produção no país (FREITAS NETO, 2011). Entretanto, fatores como a pobreza do solo, o relevo acidentado, o clima tropical úmido, a prática de uma agricultura arcaica com baixo nível tecnológico e a presença de uma aristocracia escravocrata e conservadora levaram à estagnação econômica e consequente declínio da região (FREITAS, 1999).

Desta forma, a cultura do café se expande para as férteis regiões de terra roxa do estado, conhecida como o Oeste paulista, impulsionando o desenvolvimento econômico da região com a abertura de estradas de ferro. Em 1867, é construída, com capital inglês, a São Paulo Railway ligando Jundiaí a Santos, trecho difícil de serra que significava um avanço tecnológico no transporte do café para o porto. Apesar de politicamente independente, o Brasil dependia economicamente da Inglaterra, que comprava a maior parte da produção de nosso café, além de fornecer a maior parte dos produtos manufaturados consumidos aqui.

Ricos fazendeiros passam então a financiar a extensão da malha ferroviária até suas fazendas, a fim de escoar sua produção até o porto de Santos, como é o caso da Mogiana, por exemplo, construída a partir de Campinas até a região próxima a Ribeirão Preto, em 1874, para viabilizar o cultivo do café naquela região. Da mesma forma, foram construídas a Companhia Paulista (1872) e a Sorocabana (1875), sendo que nas duas primeiras décadas do século XX todo o território paulista já se encontrava interligado pela malha ferroviária, contribuindo não somente com o escoamento da produção, mas também para a expansão das fronteiras agrícolas do estado.

Durante o século XIX observa-se que o café passa a ser o produto mais exportado pelo país, à frente do açúcar, algodão, fumo e cacau. O sistema adotado na produção cafeeira, conhecido como plantations, baseava-se na monocultura de mão de obra escrava. Os cafeicultores compravam escravos do Nordeste, de Minas Gerais ou diretamente da África. A partir da segunda metade do século XIX, a campanha abolicionista passa a ser um entrave à manutenção da mão de obra escrava das fazendas: tendo início com a Lei Feijó, em 1831, que considerava livres todos os africanos que chegassem ao Brasil a partir daquela data; passando pela Lei do Ventre Livre, de 1871, segundo a qual todos os filhos de escravos nascidos a partir de então são livres; seguida pela Lei dos Sexagenários (ou Lei Saraiva-Cotegipe) de 1885, que concedia a liberdade aos escravos de mais de 65 anos de idade; até culminar na abolição da escravatura, em 1888, com a Lei Áurea. Com a extinção do sistema escravista, a crise da mão de obra se agrava na região pela escassez de homens livres disponíveis, que partiram em direção do sertão além do fato da compra de cativos ser dispendiosa e arriscada, pois muitas vezes os escravos vindos do Norte chegavam à região sem condições de trabalhar, além da taxação de tributos pela transferência de escravos de outras províncias, instalada no ano de 1881.

Desta forma, a partir de 1840, o senador Nicolau Vergueiro, proprietário da Fazenda Ibicaba, em Limeira, começou a introduzir imigrantes portugueses, alemães e suíços, principalmente, para trabalhar em sua 
lavoura em sistema de parceria, onde o lucro líquido da venda do café seria dividido com os colonos. Estes, porém, precisavam saldar suas dívidas com os fazendeiros relativas às despesas de viagem e compras eventuais nos armazéns da própria fazenda, sobrando pouco ou nenhum dinheiro para o imigrante. A situação dos colonos em Ibicaba torna-se degradante e acaba em uma revolta no ano de 1857, que chega à Europa e culmina com alguns países proibindo a vinda de imigrantes para o Brasil (OLIVEIRA, 2001).

Diante desta situação, somada às restrições à entrada de escravos na província, as pressões por parte dos fazendeiros dão origem a um programa de financiamento por parte do estado para a introdução de imigrantes destinados à lavoura de café paulista, que incluía o pagamento de passagens da Europa até o porto de Santos, e a infraestrutura necessária para recebê-los, por meio da construção de uma hospedaria para os imigrantes no bairro do Brás, em São Paulo.

\footnotetext{
Ao aportarem, os vapores recebiam a visita de um funcionário do serviço de imigração que fazia as verificações necessárias - sobretudo em relação às exigências legais - e depois acompanhava os imigrantes até a Estrada de Ferro Inglesa para embarcá-los com destino à Hospedaria do Brás, na capital. Desembarcados, eram registrados, alojados e aguardavam até serem contratados por algum fazendeiro. O embarque para o interior da província, com passagem paga pelo governo, realizava-se na própria estação da hospedaria (GONÇALVES, 2009, p. 10).
}

A década de 1880 ficaria marcada pelo incremento da ação da política imigratória paulista, especialmente após o ano de 1887 (Gráfico 1).

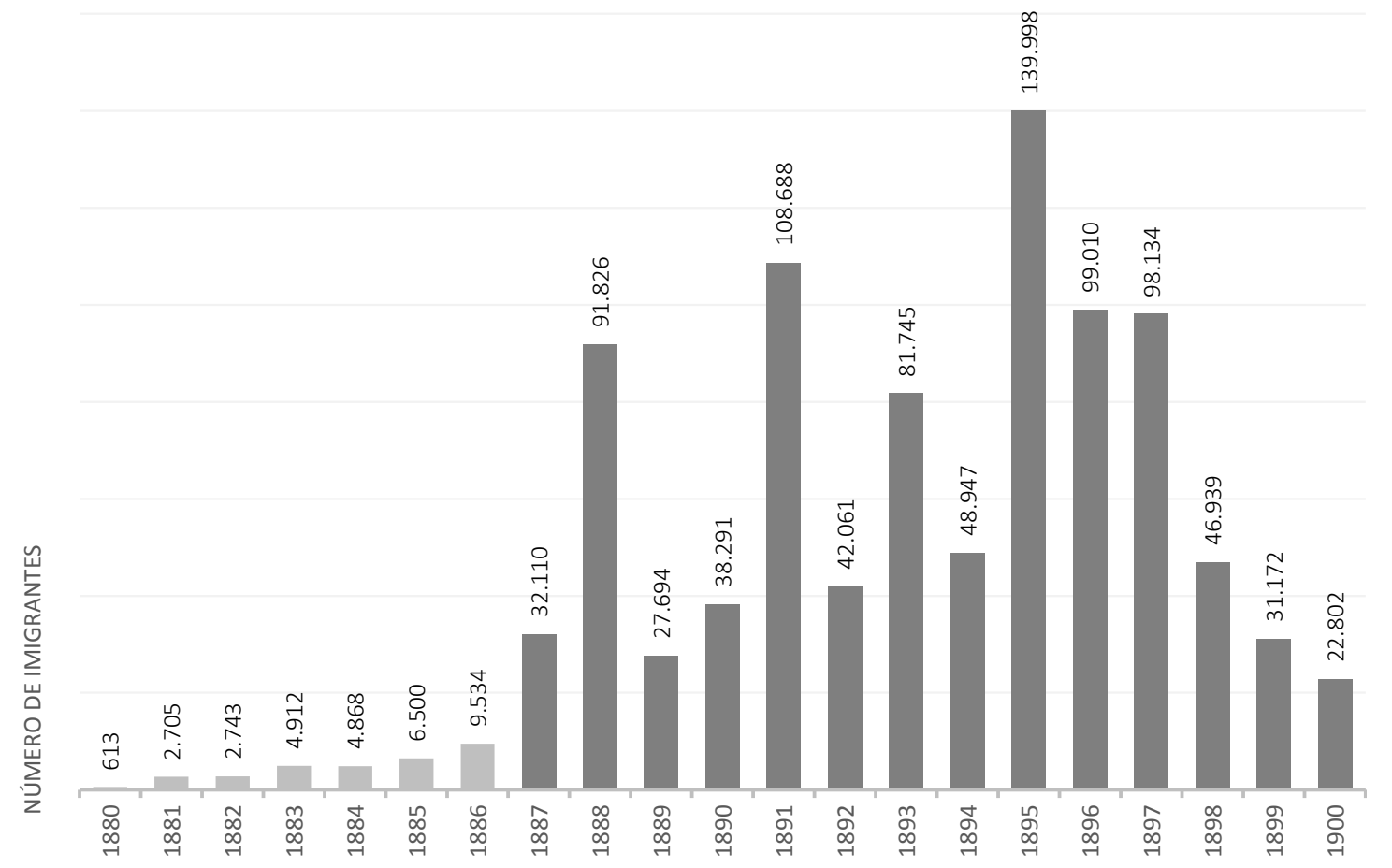

Gráfico 1. Imigração na província de São Paulo (1880-1900). Elaborado pela autora em 2015 (dados extraídos de VASCONCELOS, 1994, p. 227).

Do imenso contingente de centenas de milhares de imigrantes europeus que aqui desembarcaram neste período, a imensa maioria era de origem italiana:

O incrível "boom" cafeeiro na passagem do século é a melhor prova de que a imigração subsidiada, combinada ao sistema de colonato, foi bem sucedida em resolver o problema da mão-de-obra. Estima-se que no período entre 1884 e 1914 cerca de um milhão de homens e mulheres, agora de origem predominantemente italiana, entraram e São Paulo para trabalhar principalmente nas plantações de café (STOLCKE, 1994, p. 78). 
Outro fator fundamental neste processo foi a criação da Sociedade Promotora de Imigração por parte dos cafeicultores paulistas, que estabelecia as condições para a imigração, como, por exemplo, só aceitar imigrantes em grupos familiares, excluindo os trabalhadores desacompanhados, o que iria caracterizar um tipo de agrupamento social nas colônias fundamentado nos valores da família.

As famílias de imigrantes encaravam duras condições de trabalho somadas a uma dívida inicial para com os fazendeiros relativa à moradia e ferramentas de trabalho recebidas, que deveria ser paga com parte de seu trabalho. Todos os membros da família deveriam trabalhar - incluindo mulheres e crianças-, distribuídos em um número determinado de pés de café pelos quais receberiam o dinheiro. O contrato de trabalho incluía a casa e o quintal, onde poderiam criar algum animal para consumo, juntamente com uma pequena horta, bem como utilizar os espaços entre os pés de café para plantio de milho e feijão. O excedente deste plantio, se houvesse, era comercializado em troca de outros gêneros como sal e arroz.

As oportunidades de acumular algum capital eram raras, muitas famílias casavam seus filhos na intenção de maximizar sua capacidade produtiva e assim conseguir saldar sua dívida com o fazendeiro e almejar a compra de uma pequena propriedade, de certo em terras não férteis, desvalorizadas e de pouco aproveitamento (STOLKE, 1994).

Ao mesmo tempo, os caipiras, lavradores nômades que ocupavam as terras onde a lavoura cafeeira se desenvolveu, viram-se expulsos para as franjas de sertão sem dono ou absorvidos como mão de obra em sistema de parceria. Antes mesmo dos colonos imigrantes, os caipiras sofreram as pressões dos grandes donos de terras por não deterem a posse daquelas áreas ocupadas. Diante do poder dos fazendeiros e de uma justiça tendenciosa aos patrões, sua única alternativa se resumia em aceitar as condições de trabalho que thes eram impostas, nos moldes da exploração que ocorria com os italianos e demais imigrantes ou partir para as áreas não cultivadas do estado.

Brandão (1983) nos traz os conflitos ocorridos na antiga Penha do Rio do Peixe, hoje Itapira, entre moradores pioneiros, caipiras, e os senhores, tardios donos das terras. Após a promulgação da Lei Áurea e com a saída dos escravos das plantations, os moradores caipiras trabalharam lado a lado com imigrantes italianos que haviam chegado à região mesmo antes de 1888. Porém, nos anos seguintes com a expansão do plantio de café e posteriormente da cana-de-açúcar, tornou-se vantajoso o uso de toda a terra para as monoculturas. Deste modo, estes caipiras livres, "revestidos como agregados, colonos, camaradas, começaram a ser expulsos das fazendas de café que anos antes expulsaram os seus pais e avós de suas próprias terras" (BRANDÃO, 1983, p. 14). Décadas depois, com a decadência do café, muitos destes caipiras voltam para seu lugar de origem para trabalhar como camaradas e posteriormente como trabalhadores volantes, como se pode ver nos dias de hoje.

Os relatos do autor sobre os conflitos entre os moradores pioneiros e os senhores tardios na Penha do Rio do Peixe é um exemplo do fenômeno que ocorreu em quase todos os municípios de São Paulo, alguns antes, muitos depois.

Queiroz (1973) propõe que se identifique a civilização caipira como um gênero de vida próprio de uma camada social, de roceiros e sitiantes, que sobreviveu à civilização do café, mas que, pertencendo a uma camada social diferente das dos fazendeiros, foi obscurecida por estes, nunca tendo desaparecido. A autora sentencia: "decadentes os cafeicultores, volta-se a constatar a existência da civilização caipira" (QUEIROZ, 1973, p. 30). 
Descendentes de dois povos diferentes em origem, formação e história, a população que dá origem à base da sociedade em São Paulo nas primeiras décadas do século passado, tem muito em comum: é composta por homens livres e pobres, ligados à terra por necessidade e não por direito, explorados por aqueles detentores de poder e posse. De um lado os caipiras errantes, parceiros e agregados; do outro, os colonos italianos, imigrantes expatriados, fixados nos grandes núcleos das plantations, lutando por prosperar nos corredores da cultura cafeeira.

\subsection{Cultura caipira}

Graças a estudos da sociologia e da antropologia, como aqueles desenvolvidos por Cândido (1987) e Brandão (1983), é possível compreender a cultura caipira em sua sutileza e distinção.

Antonio Candido (1987), no final da década de 1940, inicia uma pesquisa sobre as relações entre literatura e sociedade e vai investigar como a poesia popular se manifesta no Cururu, dança cantada típica de algumas regiões do interior paulista. Porém, logo percebe a relação da cantoria com as mudanças ocorridas na sociedade caipira com o passar do tempo. Diante disso, vê-se obrigado a alargar o conhecimento da realidade social em que se inscrevia o Cururu, até culminar numa pesquisa sobre a sociologia dos meios de vida, que mais tarde dará origem ao livro Os parceiros do Rio Bonito, uma das obras mais significativas sobre a cultura caipira, seus hábitos e costumes.

Durante os anos de 1947 a 1954, o autor coletou material em diferentes regiões do estado, chegando a residir no município de Bofete por alguns meses em três períodos distintos. Por meio de suas pesquisas em meio a um agrupamento caipira, descreveu um processo e uma realidade humana característicos do fenômeno geral de urbanização no estado de São Paulo. O autor pode observar como era o modo de vida daqueles pequenos sitiantes, agregados ou parceiros num cenário de povoamento disperso, voltado para o trabalho na lavoura de subsistência e na troca dos excedentes no comércio das vilas próximas aos bairros rurais, baseado na produção de mínimos vitais, ou seja, um mínimo de alimento necessário para não se morrer de fome.

A cultura caipira pode ser assim caracterizada pela solidariedade dos mutirões vicinais nos quais, nos períodos de plantio ou de colheita, trabalham sem remuneração em terras vizinhas, num sistema de ajuda tacitamente instituída pelo hábito e pela necessidade: em troca do trabalho na roça que chega a durar diversos dias, o dono daquela terra oferece comida e cachaça ao final do turno. Desta maneira, vizinhos e familiares se revezam na lida enquanto entoam modas e cantam trovas. "As relações de vizinhança [...] constituem, entre a família e o povoado, uma estrutura intermediária que define o universo imediato da vida caipira, e em função da qual se configuram as suas relações sociais básicas" (CANDIDO, 1987, p. 58).

Vivendo em regime de autossuficiência nos povoamentos dispersos dos bairros rurais, ou nos adensamentos dos povoados, mantém com a vila mais próxima uma situação de dependência social, uma vez que o morador da fazenda, sítio ou casebre distante é o mesmo que converge periodicamente para o povoado, em ritmos variáveis, que vão da semana ao ano, em situações associadas às trocas de excedentes da produção e às celebrações de datas religiosas. 
Mas no imaginário social, o caipira é considerado culturalmente e socialmente um ser inferior, à margem dos processos de desenvolvimento pelos quais passou a região Sudeste nos últimos dois séculos. Inezita Barroso, a comendadora da chamada música sertaneja de raiz e professora de folclore, observa que o termo caipira, empregado como um adjetivo, "passou a ser pejorativo, sinônimo de brega, malvestido, idiota, velho" enquanto que, em sua opinião, simplesmente o "caipira é aquele que se conserva ligado à terra, à cultura original" (NEPOMUCENO, 1999, p. 24).

Examinemos algumas acepções do termo caipira. O Dicionário do Folclore Brasileiro de Câmara Cascudo (2002) apresenta-nos o caipira como um morador de área não urbana, de práticas culturais características.

Homem ou mulher de pouca instrução que não mora em centros urbanos. Trabalhador rural, de beira-rio ou beiramar, ou de sertão. [...] Como a terra [província de São Paulo] é aqui abundante e toca a todos esses homens a que se chama no lugar de caipiras, cultivam a ferro e fogo o torrão que possuem. [...] Esse caipira camponês-meeiro tem sua cultura analisada por meio de sua música, dança, festas, culinária, religiosidade, crendices, vestimentas, objetos de uso caseiro, enfim, sua maneira de viver em comunidade, seus usos e costumes (CASCUDO, 2002, p. 97-98).

O Dicionário Houaiss (2001) define caipira como um ser de pouco convívio social de hábitos e modos rudes.

1. que vive no interior, fora dos centros urbanos, no campo ou na roça; roceiro; 2 . que leva uma vida campestre rústica, tem pouca instrução, pouco convívio social e hábitos e modos rudes; 3. indivíduo natural ou habitante de parte das regiões Sudeste e Centro-Oeste brasileiras, especialmente São Paulo, de origem rural, caracterizados pela agricultura de subsistência, pela cultura itinerante e por não terem a posse da terra (HOUAISS, 2001, p. 563).

A definição do termo dada por Cornélio Pires ${ }^{4}$, o Poeta caipira, na década de 1930, constitui um marco para os estudos sobre a cultura caipira. O escritor colocou o caipira como personagem central de suas obras e fez uso da variante linguística regional para narrar suas histórias, expressas em dialeto caipira ${ }^{5}$. Em virtude disso, suas obras são dotadas de glossários. Vejamos o que diz sobre o caipira:

Por mais que rebusque o "etymo" de "caipira", nada tenho deduzido com firmeza. Caipira seria o aldeão; neste caso encontramos no tupy guarany "Capiabiguára". Caipirismo é acanhamento, gesto de occultar o rosto; neste caso, temos a raiz "caí" que quer dizer: "Gesto do macaco occultando o rosto". "Capipiara", quer dizer o que é do mato. "Capia", de dentro do mato: faz lembrar o "capiáu mineiro. "Caapi", - "trabalhar na terra, lavrar a terra" - "Caapiára", lavrador. E o "caipira" é sempre lavrador. Creio ser este último caso mais acceitavel, pois, "caipira" quer dizer "roceiro", isto é, lavrador.

Sinonimos de "caipira" conheço apenas os seguintes - "Capiáu", em Minas; "quejeiro", em Goyaz; "matuto", Estado do Rio e parte de Minas; "mandy", sul de S. Paulo; guasca ou gaúcho no Rio Grande do Sul; "tabaréo", Districto Federal e alguns outros pontos do paiz; "caiçara", no litoral de S. Paulo e em todo o paiz, "sertanejo" (PIRES, 1985, p. 139).

Cornélio Pires (1985) ainda desdobra o camponês paulista em tipos étnicos e, assim, "uma mesma categoria de sujeito de trabalho e cultura camponesa, constitui desiguais segundo a raça ou a mistura delas: o branco, o negro, o caboclo e o mulato" (BRANDÃO, 1983, p. 30). O caipira branco é o descendente de

4 O músico, poeta e folclorista Cornélio Pires (1884-1958) é considerado um dos maiores compiladores dos costumes, das crenças, das superstições e das tradições caipiras. Escreveu, entre os anos 1910 e 1945, mais de 20 livros de contos cujos temas residem no universo cultural do homem do interior paulista. Destacam-se entre eles, Conversas ao Pé do Fogo (1921), As Estrambóticas Aventuras do Joaquim Bentinho - o queima campo (1924), Quem Conta um Conto (1916) e Mixórdia (1927). Fez palestras, montou caravanas de violeiros, criou monólogos para apresentações de cantadores e humoristas, levando-os para palcos e picadeiros do interior do estado. Em 1929, Pires prensou o primeiro disco de música e humor caipira com anedotas, desafios, declamações e cateretês (OLIVEIRA, 2001).

5 Amadeu Amaral dedica O Dialeto Caipira (1955) ao primo Cornélio Pires, ao escritor regionalista Valdomiro Silveira, e ao estudioso do folclore Alberto Faria. 
povoadores portugueses ou migrantes europeus; o caipira caboclo, tipo próximo ao índio, descende direto dos bugres; o caipira negro é o tipo formado por pretos velhos e negros jovens, e finalmente o caipira mulato, do cruzamento português com o africano.

Do ponto de vista histórico, como descrito anteriormente, esse tipo de cultura e vida social foi condicionada inicialmente pelo fenômeno da mobilidade resultante do período da expansão geográfica dos vicentinos por meio das bandeiras dos séculos XVI, XVII e XVIII, que incorporaram o território às terras da Coroa portuguesa na América, capturaram escravos e descobriram jazidas de minério de grande valor. A vida social do caipira assimilou e conservou os elementos condicionados pelas suas origens nômades.

A combinação dos traços culturais indígenas e portugueses obedeceu ao ritmo nômade do bandeirante e do povoador, conservando as características de uma economia largamente permeada pelas práticas de presa e coleta, cuja estrutura instável dependia da mobilidade dos indivíduos e dos grupos. Por isso, na habitação, na dieta, no caráter do caipira, gravou-se para sempre o "provisório da aventura" (CANDIDO, 1987, p. 37).

A figura do caipira rude considerado "biologicamente degenerado, seja pela descendência de maus cruzamentos raciais, seja pela associação da fome crônica com as doenças do sertão" (BRANDÃO, 1983, p. 6) pode ser identificada em diferentes períodos da história.

O viajante francês Augusto de Saint-Hilaire, entre 1816 e 1822, percorreu de Goiás ao Rio Grande do Sul passando por São Paulo, em função de suas pesquisas na área da botânica. De volta à França escreve uma série de livros sobre suas expedições e descreve os hábitos do povo das localidades por onde passou. Em Viagem à Província de São Paulo, escrito em 1851, Saint-Hilaire narra sua experiência com os caipiras:

Enquanto descrevia e examinava as plantas, aproximou-se um homem do rancho, permanecendo várias horas a olhar-me, sem proferir qualquer palavra. Desde Vila Boa até Rio das Pedras, tinha eu quiçá cem exemplos dessa estúpida indolência. Esses homens, embrutecidos pela ignorância, pela preguiça, pela falta de convivência com seus semelhantes e, talvez, por excessos venéreos primários, não pensam: vegetam como árvores, como as ervas do campo. Obrigado pela ventania a deixar o rancho, fui procurar abrigo numa das cabanas principais, mas admirei-me da desordem e da imundície reinantes na mesma. Grande número de homens, mulheres e crianças desde logo rodeou-me. Os primeiros só vestiam uma camisa e uma calça de tecido de algodão grosseiro; as mulheres, uma camisa e uma saia simples. Os goianos e mesmo os mineiros de classe inferior vestem-se com muito pouco apuro, mas pelo menos, são limpos; a indumentária dos pobres habitantes de Rio das Pedras era tão imunda quanto suas cabanas. A primeira vista, a maioria deles parecia ser constituída por gente branca; mas, a largura de suas faces e a proeminência dos ossos das mesmas traía, para logo, o sangue indígena que Ihes corre nas veias, mesclado com o da raça caucásica... Pode-se acrescentar, ao demais, que à indolência juntam eles, geralmente, a idiotice e a impolidez... (SAINT-HILAIRE, 1972, p. 45).

À imagem depreciativa do caipira muito contribuiu Monteiro Lobato, ao criar a figura de Jeca Tatu em dois artigos publicados no jornal O Estado de São Paulo, em 1914: "Velha Praga", onde denuncia o hábito pernicioso das queimadas das matas pelos caboclos vizinhos de sua fazenda, herdada do avô no município de Taubaté, e "Urupês" (transformado em livro de contos homônimo em 1918). Lobato reduz o caipira ao um sujeito de cócoras.

Porque a verdade nua manda dizer que entre as raças de variado matiz, formadoras da nacionalidade e metidas entre o estrangeiro recente e o aborígine de tabuinha no beiço, uma existe a vegetar de cócoras, incapaz de evolução, impenetrável ao progresso. Feia e sorna, nada a põe de pé. [...] Nada o esperta. Nenhuma ferrotoada o põe de pé. 
Social, como individualmente, em todos os atos da vida, Jeca, antes de agir, acocora-se. [...] Para comer, negociar uma barganha, ingerir um café, tostar um cabo de foice, fazê-lo noutra posição será desastre infalível. Há de ser de cócoras. [...] Seu grande cuidado é espremer todas as consequências da lei do menor esforço - e nisto vai longe. [...] Sua casa de sapé e lama faz sorrir aos bichos que moram em toca e gargalhar ao joão-de-barro. Pura biboca de bosquímano. Mobília, nenhuma. A cama é uma espipada esteira de peri posta sobre o chão batido. Às vezes se dá ao luxo de um banquinho de três pernas - para os hóspedes. Três pernas permitem equilíbrio; inútil, portanto, meter a quarta, o que ainda o obrigaria a nivelar o chão." Para ao final sentenciar "Seus netos não meterão quarta perna ao banco. Para quê? Vive-se bem sem isso (LOBATO, 1994, p. 92).

A repercussão dos textos de Lobato aumenta quando Rui Barbosa, então candidato à presidência da república em 1919, época em que a ideia de atraso nacional estava vinculada à degeneração racial fruto da mestiçagem, faz um discurso no Teatro Lírico, no Rio de Janeiro, e se vale do personagem de Lobato em nome das chamadas questões sociais, como um exemplo de trabalhador que é resultante do sistema de oligarquias a serem combatidas.

Conheceis por ventura o Jeca Tatu do 'Urupês' de Monteiro Lobato, o admirável escriptor paulista? Tivestes, algum dia, ocasião de ver surgir, debaixo desse pincel de uma arte rara na sua rudeza, aquele typo de uma raça que 'entre as formadoras de nossa nacionalidade' se perpetua a vegetar de cócoras, incapaz de evolução ou impenetrável ao progresso? [Para à frente indagar] Não seria o povo brasileiro mais do que esse espécimen do caboclo mal desasnado, que não se sabe ter de pé, nem mesmo se senta, conjunto de todos os estigmas da calaçaria e da estupidez, cujo voto se compre com um rolete de fumo, uma andaina de sarjão e uma vez d'aguardente? (BARBOSA, 1983, p.77).

Com o avanço das campanhas higienistas e das pesquisas no campo da saúde pública, a ciência demonstrava que o atraso do país poderia estar relacionado às doenças e a falta de saneamento, e não à miscigenação. Lobato publica outro artigo, desta vez para a Revista do Brasil, da qual era um dos fundadores junto com Amadeu Amaral, justamente um folclorista, intitulado "A tropa de Tremembé", onde ensaia uma retratação.

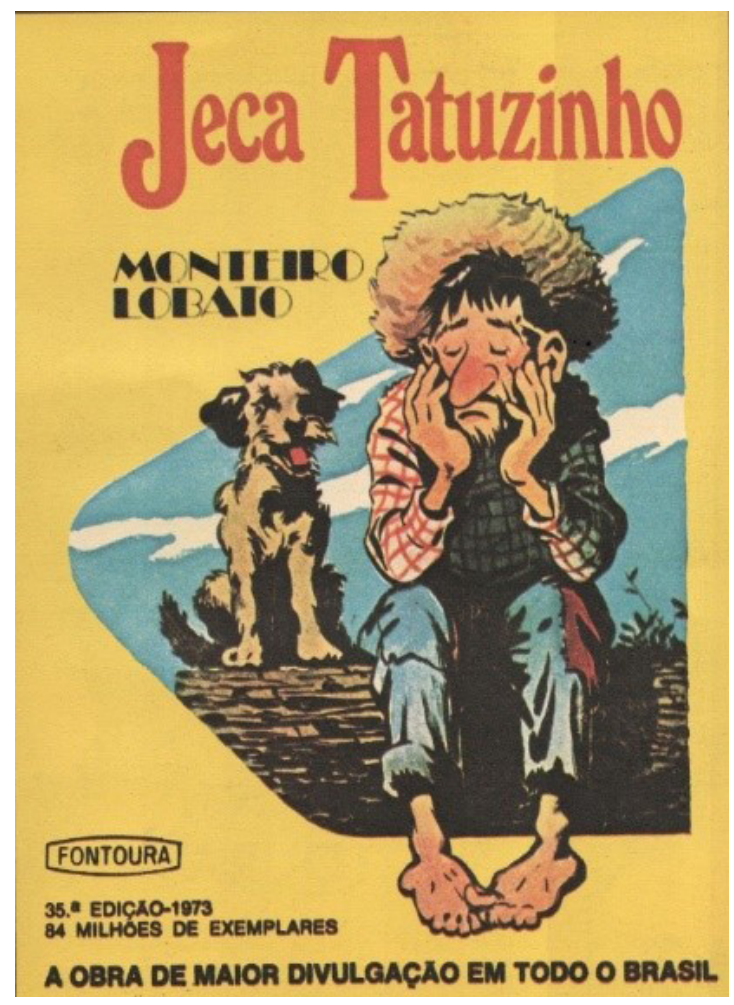

Figura 5. Capa do Almanaque Jeca Tatuzinho, 35. ed., 1973 (ALMANAQUE, 2000).

\begin{abstract}
A nossa gente rural possui ótimas qualidades de resistência e adaptação. É boa por índole, meiga e dócil. O pobre caipira é positivamente um homem como o italiano, o português, o espanhol. Mas é um homem em estado latente. Possui dentro de si grande riqueza em forças. Mas força em estado de possibilidade. E é assim porque está amarrado pela ignorância e falta de assistência às terríveis endemias que lhe depauperam o sangue, caquetizam o corpo e atrofiam o espírito. O caipira não é assim. Está assim. Curado, recuperará o lugar a que faz jus no concerto etnológico (LOBATO, 1964, p. 34).
\end{abstract}

Ainda na década de 1920, o escritor, que era amigo de Candido Fontoura, fabricante do Biotônico Fontoura, cria o personagem Jeca Tatuzinho (Figura 5): um caipira que ensinava noções de higiene a crianças e à população em geral por meio de um panfleto distribuído em farmácias, numa campanha sanitarista a serviço da divulgação de um país progressista. 
Por trás das ideias de "progresso" e "civilização" que assolavam o Brasil neste período, havia a crença de que grupos inferiores da sociedade impediam o país de seguir o rumo à civilização.

Park comenta sobre o caráter discriminatório destas ações:

Seria necessário tirar o cheiro da terra e dos excrementos que acompanha o habitante do campo, limpando e arejando suas residências, organizando os espaços, regularizando relações, abrindo caminho da casa do camponês até a casa do futuro operário (Park, 1999, p. 145).

Impulsionado pelo sucesso do Jeca Tatuzinho, Fontoura lança seu Almanaque elaborado e ilustrado por Monteiro Lobato, com uma tiragem inicial de 50 mil exemplares.

Espécie de revista publicitária de distribuição gratuita, também utilizada nas escolas como material de leitura e educação, o Almanaque possuía cerca de 40 páginas com informações que iam de horóscopo à higiene e saúde, além de trazer propaganda dos produtos Fontoura, como o remédio para amarelão Ankilostomina Fontoura (Figura 6). Para se ter uma ideia do alcance da publicação, desde a primeira edição até os anos 1970, o Laboratório Fontoura recebeu diariamente uma média de 30 cartas de leitores interessados em seu almanaque, que atravessou praticamente todo o século XX, e atingiu uma tiragem superior a 100 milhões de exemplares em 1982, quando deixou de ser impresso (PARK, 1999).

Se por um lado, o Jeca Tatuzinho do Almanaque Fontoura vivia cabisbaixo acometido de doenças como o amarelão, o Jeca Tatu que Mazzaropi leva ao cinema é uma figura simplória, mas ao mesmo tempo esperta, maliciosa, capaz de enganar os outros com uma falsa ingenuidade a seu proveito (Figura 7).

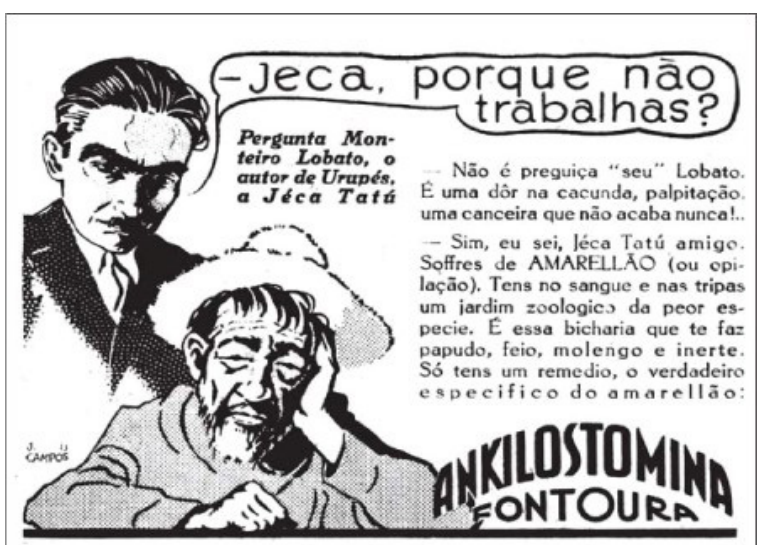

Figura 6. Propaganda de remédio para amarelão. llustração de J. U. Campos, Almanaque do Biotônico, 1935 (OLIVEIRA, 2011).

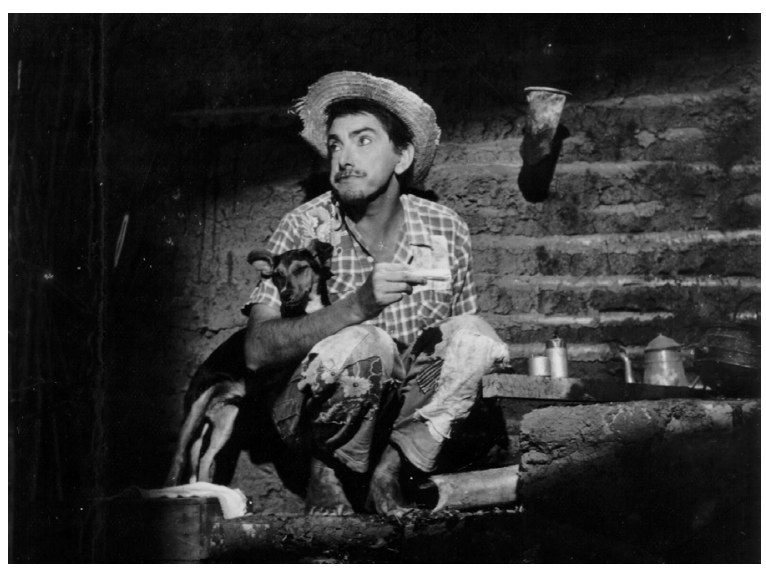

Figura 7. Jeca Tatu de Mazzaropi, 1959 (O "GRANDE AMIGO", 2012).
O cineasta, ator, produtor, roteirista, cantor e empresário Amécio Mazzaropi faria enorme sucesso abordando um tema já saudoso por milhares de espectadores que deixaram a zona rural e migraram para as cidades nas décadas de 1940 e 1950 do século passado.

Essa enorme massa de trabalhadores anteriormente rurais, historicamente vinculada ao trabalho independente, assustadoramente ameaçada em sua sobrevivência pelo modelo capitalista excludente planejado e executado para o campo, viria a integrar, em potência, a já tradicional legião de fãs de Mazzaropi, agora, porém, em um outro momento da história da economia e da sociedade brasileiras, em que os "novos citadinos" e "também novos consumidores de cinema" encontravam-se completamente desestruturados em relação ao "modus vivendi" que deveriam assumir, necessitando recuperar de algum modo sua identidade [...]. O caipira de Mazzaropi, no plano simbólico, preencheria, como nenhuma outra personagem, tal carência (BARSALINI, 2002, p. 95). 
Contrariando o projeto de modernidade nacional do Estado Novo, o caipira Jeca Tatu pode ser entendido como uma resistência daquele Brasil autêntico e marginalizado, por meio de seus códigos de identificação que Mazzaropi sabia como utilizar. Em meio a um acelerado movimento de modernização e urbanização desde a Revolução de 1930, e o crescimento da indústria cinematográfica no Brasil, surge aquela figura rústica para competir com a malandragem urbana de Oscarito e Grande Otelo, no gênero popular de comédia com acento regional, já que o caipira não seria aquele a se vincular uma ideia de identidade nacional, estando esta reservada à cultura urbana e carioca.

\begin{abstract}
A primeira imagem que temos de Mazzaropi no cinema nacional, ou seja, o primeiro plano do ator (após os planos dos créditos iniciais) no seu primeiro filme, lançado em 1952 pela Vera Cruz, Sai da frente, apresenta a personagem dormindo numa cama, e logo um despertador vem interromper-lhe o sono. De súbito, o relógio para de funcionar, soltando todas as peças, e observamos Mazzaropi despertar lentamente. O corpo do caipira, ao levantar, é bastante pesado, lento e desengonçado. O caipira desperta e, 'ingenuamente', conserta o relógio, colocando desordenadamente todas as peças de volta à caixa. Se por um lado esse caipira deve ser conduzido ao mundo do trabalho, abandonando as atrasadas práticas rurais de sua rusticidade cultural, a inércia do corpo de Mazzaropi promove um confronto com este novo ritmo moderno que se desdobra numa recusa a estas novas regras impostas pela ética do trabalho capitalista. O relógio que o desperta é precário e a maneira como o conserta mostra-nos que ele jamais voltaria a funcionar, o que denota e reforça mais uma vez a tensão entre estes dois mundos, o do trabalho e do ritmo da cidade, e o da 'indolência' caipira. O riso que a cena provoca, ao mostrar o caipira 'consertando' o relógio, mostra-nos o deboche com que a personagem trata este 'tempo urbano', subvertendo suas marcas e ridicularizando suas demandas (BRAGANÇA, 2009, p. 111, grifo do autor).
\end{abstract}

Estava delineada a imagem do caipira que sobrevive até os dias de hoje no imaginário popular graças, em grande parte, às campanhas higienistas da década de 1930 e à figura propagada pela indústria cultural na década de 1960: este misto de indolente e preguiçoso, cômico e malicioso.

\footnotetext{
A indústria cultural lida com homogeneizações, estereotipias e padronizações, e o caipira de Mazzaropi, ainda que traduzisse todo um imaginário ligado à cultura rústica do interior paulista, também adotava mecanismos de pasteurização. A partir de Jeca Tatu, filme dirigido por Milton Amaral em 1959, seu figurino tornaria-se invariável: a calça acima da botina, deixando aparecer uma parte da canela, o chapéu de palha, o fumo de rolo, a camisa xadrez, e o andar desengonçado, com os braços ligeiramente abertos, ombros levemente suspensos, o que fazia encolher seu pescoço e lhe conferia um ar extremamente caricatural (BRAGANÇA, 2009, p. 110).
}

Ficam deste modo impregnados no termo caipira os estereótipos criados pela indústria cultural, coexistindo com a realidade sobre sua origem, costumes e valores, isto é, um tipo rústico, de hábitos simples, herdados de um tipo de vida nômade devido à falta de propriedade da terra, que sobrevive graças ao plantio de pequenas culturas e cujas relações sociais se escoram nas práticas vicinais de camaradagem, nas idas ocasionais ao centro mais próximo nas datas santas do calendário para a quermesse e os festejos, e nas horas de lazer regadas à cachaça, embaladas pelas modas de viola. 


\subsection{Folclore, mercantilização e inter-relações culturais}

"Folclore é uma palavra que já nasceu entre parênteses"

(BRANDÃO, 1982, p. 27)

Desde sua concepção, em 1846, quando William John Thom cria o termo folk-lore a partir da junção de folk (que significa povo) e lore (saber) para designar sua área de estudos, até os dias de hoje, sua acepção sempre gerou controvérsias entre pesquisadores e folcloristas. Compreender folclore como os "saberes do povo" suscita no mínimo duas questões relevantes: o que se entende por povo e a que tipo de saber se refere.

Segundo Ortiz (1985), os estudos sociológicos sobre o povo brasileiro têm início com autores do século XIX como Sílvio Romero, Euclides da Cunha e Nina Rodrigues que iniciam o debate em torno do caráter brasileiro baseados na ideia de raças, conceito que se insere na corrente evolucionista em voga naquele momento, profundamente influenciados pelo crescente processo de miscigenação entre índios, negros e brancos.

Nas primeiras décadas do século XX, com o incremento da industrialização que vai transformar as relações na sociedade, bem como o aprofundamento dos estudos por parte dos intelectuais, há um deslocamento da ideia de raça para a noção de cultura. Os folcloristas estão interessados em buscar o "registro antes que acabe" de modo a configurar um "espírito do povo".

Décadas depois, observa Benjamin (2011, p. 1) "a inserção da ideia de sociedade de classes, implícita no conceito de folclore, atrai para a discussão intelectuais marxistas, com análises, posições, ideias e teorias próprias, em geral divergentes do que se havia estabelecido, aumentando a controvérsia".

Inicia-se uma nova fase onde a visão politizada sobre o tema precede a investigação acerca das manifestações populares em si. O embate se dá uma vez que as abordagens anteriores dos estudos em folclore não consideravam a cultura popular no interior na sociedade, e sim "como uma outra cultura ao lado (ou no fundo) da cultura dominante" (CHAUÍ, 1986, p. 16); além disso, estes estudos relacionavam o termo popular às camadas subalternas das sociedades rurais, o que excluía a possibilidade de um folclore urbano, por exemplo, e a exclusão do operariado, do assalariado de serviços e da pequena burguesia de sua condição de povo.

Com relação à definição de "saberes", para alguns estudiosos à época, estariam aí incluídos somente os imateriais, excluindo-se o artesanato ou a culinária, por exemplo. Para outros, a cultura material só estaria ligada ao folclore quando fizesse parte do rito folclórico em questão, como um estudo sobre uma determinada festa popular que incluiria suas vestimentas.

Um dos pioneiros nos estudos do folclore no Brasil, o poeta e escritor Amadeu Amaral (1976), faz um discurso à Academia Brasileira de Letras em 1931, defendendo a criação da Sociedade Demológica de São Paulo, primeira proposta no sentido de se consolidar uma associação para os estudos do folclore, inicialmente localizada em São Paulo, e que poderia no futuro se expandir para o restante do país. Em sua fala pode-se perceber que, já àquele tempo, a definição do campo do folclore não encontrava consenso. 
Não se deve entrar nestas contendas teóricas a respeito da delimitação do domínio do campo do folclore já que o que não deixa dúvidas é que o folclore tem o seu domínio, que não se confunde com o de nenhuma outra sciéncia; se não é fácil reconhecer-lhe exatamente as divisas, é em troca facílimo verificar que existe um núcleo de coisas e de factos sôbre o qual ninguém Ihe contesta a soberania (AMARAL, 1976, p. 52).

Em Tradições populares, livro que traz uma série de artigos e conferências do escritor publicados no jornal O Estado de S. Paulo entre os anos de 1926 e 1928, Amaral (1976) coloca de modo anacrônico e abrangente a sua definição para o campo, ao dizer que "o folclore estuda os produtos da mentalidade popular" (AMARAL, 1976, p. 52) afirmando que o povo tem uma ciência a seu modo, uma arte, filosofia, literatura, direito, religião e moral "que se distinguem dos que lhe são impostos pela cultura da escola ou the vêm por infiltração natural de influências ambientes" (AMARAL, 1976, p. 52).

O autor afirma que "tudo isso pode se melhor encontrar, naturalmente nas populações rurais [...] terreno onde as personalidades mais visivelmente se dissolvem nas feições da coletividade, pensando sentindo e agindo por conta desta" (AMARAL, 1976, p. 53). Com isso, reforça a ideia do folclore enquanto produto da população rural pelo caráter coletivizado destes grupos, referindo-se ao hábito dos mutirões nos bairros caipiras que Candido (1987) mais tarde vai estudar em profundidade. Pondera, no entanto, que não há um limite intransponível entre o que se entende por zona rural ou os subúrbios das zonas urbanas ou urbanizadas, e que certas manifestações folclóricas não respeitam estas barreiras geográficas virtuais, apontando para o fato posteriormente aceito nos estudos da área, acerca da maleabilidade dos contornos do folclore (AMARAL, 1976).

Amaral apresenta um plano para servir de guia para o coletor de materiais e a catalogação destes materiais. Divide seu plano em onze categorias, subdivididas em diversas seções: (I) Poesia, música e dança; (II) Narrações; (III) Linguagem popular; (IV) Técnicas e artes; (V) A casa e a indumentária; (VI) Atos coletivos; (VII) Alimentação e bebidas; (VIII) Crenças e observâncias; (IX) Direito popular; (X) Saber popular; (XI) Escritos (AMARAL, 1976).

Observando a categoria (V), A casa e a indumentária, na primeira seção intitulada a casa, o autor sugere incluir móveis, utensílios, adornos, o jardim, a horta, o pomar, a criação miúda e os brinquedos. Nota-se aqui que, além da inquestionável materialidade presente na proposta, o autor já imaginara o universo pesquisável doméstico, incluindo não só os equipamentos e utensílios, mas também o jardim e a pequena criação. Detalha todas as categorias e observa: o principal defeito do quadro que propõe é que mais de uma divisão entra pela esfera da outra, cruzando limites. Isto pode ser observado na categoria Técnicas e artes (IV), onde a seção Artefatos traz como exemplo tecidos, chapéus, calçados, arreios, cerâmica, rendas e bordados, instrumentos e aparelhos de caça, joias etc. Deste modo vê-se que cerâmicas podem ser utensílios da casa, mas também artefatos. Sobre esta sobreposição de categorias, o autor se redime ao afirmar ser impossível obedecer divisões estanques neste domínio (AMARAL, 1976).

Amaral estava à frente de seu tempo, uma vez que, no final do século XIX, início do século XX, a maioria dos estudiosos considerava folclore apenas as produções orais (ou espirituais) do saber popular. Para os antropólogos em geral, folclore compreendia o equipamento mental de um povo. Brandão (1982) nos traz alguns exemplos que confirmavam esta vertente, dentre eles a de Arthur Ramos, um dos pioneiros do estudo sistemático do folclore brasileiro, que definia folclore "como uma divisão da antropologia cultural que estuda os aspectos da cultura de qualquer povo, que dizem respeito à literatura tradicional: mitos, contos, 
fábulas, adivinhas, música e poesia, provérbios, sabedoria tradicional e anônima" (BRANDÃO, 1982, p. 30). Porém, este conceito evoluiu e sua definição alargou-se entre as décadas de 1930 e 1950. Apesar da Sociedade Demológica de São Paulo não ter sido instituída, Amaral deixou aos seus contemporâneos e às gerações futuras, uma contribuição metodológica pioneira nos estudos do folclore, além da visão abrangente do campo: "a abordagem sociológica como uma nova maneira de focalizar os fatos folclóricos, estimando que o significado destes só poderia ser plenamente compreendido quando fossem estudados mergulhados no contexto sociocultural de que fazem parte" (QUEIROZ, 1996, p. 51).

Florestan Fernandes (1989) vai dizer que, "Mario de Andrade está para a música assim como Amadeu Amaral está para a poesia e a literatura" (FERNANDES, 1989, p. 43). Isso se deve não só às pesquisas individuais destes dois intelectuais do começo do século XX, mas a sua atuação política nas questões relativas à cultura popular. Do ponto de vista das políticas públicas, foi Mário de Andrade quem obteve as primeiras realizações no campo do folclore, com a criação, em 1937, da Sociedade de Etnografia e Folclore, assumindo a direção do recém-inaugurado Departamento de Cultura do Município de São Paulo. Paralelamente, é inaugurado o curso de Ciências Sociais da Universidade de São Paulo (USP) iniciando uma aproximação entre os folcloristas e os acadêmicos, principalmente por meio do contato do professor Claude Lévi-Strauss (recém-chegado ao Brasil para assumir um posto na cátedra de Sociologia da USP, onde vai lecionar de 1935 a 1938) com o poeta Mário de Andrade. Neste contexto começa efetivamente a surgir o movimento folclórico no Brasil.

Em 1946, em resposta a uma solicitação da UNESCO, o governo brasileiro cria o Instituto Brasileiro de Educação, Ciência e Cultura (IBECC) junto ao Ministério das Relações Exteriores, atendendo a folcloristas de quase todo o país, por meio das Comissões Estaduais. Segundo Golovaty (2005), o instituto dará origem à Comissão Nacional de Folclore (CNFL), órgão que irá extrapolar o âmbito local das iniciativas até então realizadas, conectando pesquisadores de todo o país.

Por meio das Subcomissões Estaduais de Folclore,

a rede de pesquisas se estendeu ao interior de cada estado, propiciando uma capacidade de registro/coleta de materiais nunca realizada no Brasil. A partir desta mobilização organizaram-se várias semanas de folclore (no nível estadual), quatro Semanas Nacionais de Folclore, quatro congressos nacionais (1951, 1953, 1957 e 1963, respectivamente Rio de Janeiro, Curitiba, Bahia e Porto Alegre) e uma assembleia internacional, em São Paulo, nas comemorações do quarto centenário da cidade (1954), com participação de folcloristas de renome [...]. Em 1951, no I Congresso Nacional de Folclore, surge a Carta do Folclore Brasileiro, tida como a diretriz científica do movimento, base para os pesquisadores de todo o país (GOLOVATY, 2005, p. 31).

A carta evidencia a inclusão do fator material nos estudos folclóricos, e, apesar de ainda colocar a tradição como uma característica do fato folclórico, reconhece as manifestações populares não tradicionais, com base na aceitação coletiva. Estabelece o seguinte:

Reconhece o estudo do Folclore como integrante das ciências antropológicas e culturais, condena o preconceito de só considerar como folclórico o fato espiritual e aconselha o estudo da vida popular em toda sua plenitude, quer no aspecto material, quer no aspecto espiritual.

Constituem o fato folclórico as maneiras de pensar, sentir e agir de um povo, preservadas pela tradição popular e pela imitação e que não sejam diretamente influenciadas pelos círculos eruditos e instituições que se dedicam ou à renovação e conservação do patrimônio científico e artístico humanos ou à fixação de uma orientação religiosa e filosófica. 
São também reconhecidas como idôneas as observações levadas a efeito sobre a realidade folclórica, sem o fundamento tradicional, bastando que sejam respeitadas as características de fato de aceitação coletiva, anônima ou não, e essencialmente popular (BENJAMIN, 2011, p. 1-2).

A partir daí os estudos folclóricos alargaram seu foco, não se restringindo mais às produções orais e à cultura imaterial. Porém, apesar dos objetos terem conquistado um lugar importante na definição do campo, reforçando a relevância dos estudos em cultura material, a atitude paternalista dos agentes culturais em relação ao folclore continuou a suscitar críticas como a de Lina Bo Bardi (1994) ao falar sobre os objetos expostos na inauguração do Conjunto do Unhão, na Bahia, em 1963, com a Exposição "Civilização do Nordeste". Lina propunha inclusive que não se usasse o termo folclore, preferindo arte popular, uma vez que, em sua opinião, a palavra folklore trazia "uma herança estática e regressiva amparada paternalisticamente pelos responsáveis pela cultura" (BARDI, 1994, p. 37) enquanto que, em sua opinião, "arte popular melhor define a atitude progressiva da cultura popular ligada a problemas reais" (BARDI, 1994, p. 37). A autora usa aqui a palavra arte não somente no sentido artístico, mas também no de fazer tecnicamente. Trataremos adiante de outros aspectos da relação entre cultura popular e as esferas de poder da sociedade.

A ideia de folclore vinculado à tradição popular preservada estendeu-se a outras dimensões mais atuais, associadas à vida do povo, à sua capacidade de criar e recriar.

Tudo aquilo que, existindo como forma peculiar de sentir e pensar o mundo, existe também como costumes e regras de relações sociais. Mais ainda, como expressões materiais do saber, do agir, do fazer populares. Não apenas a legenda do herói ancestral, o mito (aquilo que muitas vezes explica, tanto a camponeses quanto a índios, a origem do mundo e de todas as coisas), mas também o rito, a celebração coletiva que revive o mito como festa, com suas procissões, danças, cantos e comilanças cerimoniais. Não apenas a celebração, o rito, o ritual, mas a própria vida cotidiana e os seus produtos: a casa, a vestimenta, a comida, os artefatos do trabalho, os instrumentos da fiadeira [...]. Mais do que isso, o seu trabalho, o processo de fazer a colcha com o saber próprio de uma cultura típica (BRANDÃO, 1983, p. 45).

A materialidade passa a ser elemento chave nas questões do folclore uma vez que se compreende necessário considerar os significados inerentes aos objetos produzidos naquela determinada manifestação popular. Nesta mesma direção Câmara Cascudo (1984) nos apresenta sua acepção para o termo no Dicionário do Folclore Brasileiro. O autor fala da habilidade do objeto projetar interesse humano além da sua finalidade ou funcionalidade, referindo-se à capacidade simbólica dos objetos folclóricos, carregados de significados emocionais.

Folclore: é a cultura do popular, tornada normativa pela tradição. Compreende técnicas e processos utilitários que se valorizam numa ampliação emocional, além do ângulo do funcionamento racional.[...] Qualquer objeto que projete interesse humano, além de sua finalidade imediata, material e lógica, é folclórico (CASCUDO, 1984, p. 334-335).

Bosi (1992) reforça esta concepção holística quando afirma que "uma teoria da cultura brasileira" deveria ter como matéria prima "o cotidiano físico, simbólico e imaginário dos homens que vivem no Brasil", de onde se buscaria teores e valores, sem distinção entre as esferas material ou simbólica.

No caso da cultura popular, não há uma separação entre uma esfera puramente material da existência e uma esfera espiritual ou simbólica. Cultura popular implica modos de viver: o alimento, o vestuário, a relação homem- mulher, a habitação, os hábitos de limpeza, as práticas de cura, as relações de parentesco, a divisão das tarefas durante a jornada e, simultaneamente, as crenças, os cantos, as danças, os jogos, a caça, a pesca, o fumo, a bebida, os provérbios, os modos de cumprimentar, as palavras tabus, os eufemismos, o modo de olhar, o modo de sentar, o modo de andar, 
o modo de visitar e ser visitado, as romarias, as promessas, as festas de padroeiro, o modo de criar galinha e porco, os modos de plantar feijão, milho e mandioca, o conhecimento do tempo, o modo de rir e de chorar, de agredir e de consolar... A enumeração é acintosamente caótica passando do material ao simbólico e voltando do simbólico para o material, pois o intento é deixar bem clara a indivisibilidade, no cotidiano do homem rústico, de corpo e alma, necessidades orgânicas e necessidades morais" (BOSI, 1992, p. 324).

Passados mais de quarenta anos da edição da Carta do Folclore de 1951, realiza-se em Salvador o VIII Congresso Brasileiro de Folclore, no ano de 1995, onde é feita a releitura da Carta para a sua atualização, de modo a se adequar às transformações da sociedade brasileira ocorridas neste período, bem como refletir as contribuições dos estudos das Ciências Humanas e Sociais ao campo e o alinhamento com as Recomendações da UNESCO sobre Salvaguarda do Folclore. Na sua introdução enfatiza-se a relação entre o folclore a identidade cultural dos povos: "A importância do folclore como parte integrante do legado cultural e da cultura viva, é um meio de aproximação entre os povos e grupos sociais e de afirmação de sua identidade cultural" (CARTA, 1995, p. 1-5).

Não se discute mais a pertinência da materialidade nos estudos folclóricos; outras características como tradicionalidade e dinamicidade são incorporadas. O primeiro capítulo apresenta a definição para o campo:

Folclore é o conjunto das criações culturais de uma comunidade, baseado nas suas tradições expressas individual ou coletivamente, representativo de sua identidade social. Constituem-se fatores de identificação da manifestação folclórica: aceitação coletiva, tradicionalidade, dinamicidade, funcionalidade. Ressaltamos que entendemos folclore e cultura popular como equivalentes, em sintonia com o que preconiza a UNESCO. A expressão cultura popular manter-se-á no singular, embora entendendo-se que existem tantas culturas quantos sejam os grupos que as produzem em contextos naturais e econômicos específicos (CARTA, 1995, p. 1).

Nos quinze capítulos que compõem a carta, nota-se que certas características atribuídas ao folclore até então deixam de ser obrigatórias ou passam a ser relativizadas. Roberto Câmara Benjamin (2011), Presidente da Comissão Pernambucana de Folclore, diante desta nova perspectiva, faz algumas considerações sobre estes aspectos revisitados.

Primeiramente, com relação ao anonimato no folclore, ou seja, da autoria desconhecida, característica que tem sido relativizada uma vez que deixa de fora, por exemplo, certas manifestações do artesanato ou composições de repentistas identificadas no ato de sua criação. O conceito de anonimato tem sido reinterpretado graças à ideia de aceitação coletiva.

Segundo o autor, "para alguns folcloristas, a criação de um autor conhecido passa a ser folclórica quando há aceitação coletiva, quando passa a ser considerada patrimônio comum do grupo e ocorrem adições, variações e reinterpretações" (BENJAMIN, 2011, p. 1). Outro fator decorrente da aceitação coletiva é possibilitar que fatos originários da cultura de elite, aceitos e reinterpretados pelo povo, possam ser considerados folclore.

A transmissão oral é outra característica que deve ser entendida de modo simbólico e não literal. De outro modo, corre-se o risco de se excluir alguns processos de transmissão de saberes relacionados a técnicas populares, ao artesanato ou mesmo à literatura de cordel, mantidos por meio da escrita.

A ideia de antiguidade relacionada ao fato folclórico tem sido descartada uma vez que sua aceitação subtrai do povo sua capacidade criativa. $O$ autor instiga-nos a refletir: "certamente, ninguém duvidará que um escritor erudito crie um conto ou um poema novo. Ao criador popular, se deveria negar tal possibilidade?" 
(BENJAMIN, 2011, p. 2). Porém, para que se coloque uma linha divisória entre o popular urbano, como, por exemplo, as canções populares que tocam no rádio, e o fato folclórico, o autor enfatiza o que considera a característica básica do folclore, a tradicionalidade. A isto o autor associa a ideia de dinamicidade.

\footnotetext{
Quando se coloca o que é tradicional em oposição ao que é novo, chega-se à negação da dinamicidade. A dinâmica cultural, a evolução constante a que todos os fatos culturais estão sujeitos não permite a admissão do entendimento do folclore meramente como uma sobrevivência do passado. Há fatos novos no folclore, pela criação contemporânea do povo e folclorização de fatos ou manifestações eruditos que estão merecendo a aceitação coletiva. [...]. A tradicionalidade é entendida hoje como uma continuidade, onde os fatos novos se inserem sem uma ruptura com o passado, mas que se constroem sobre esse passado - são, por exemplo, materiais novos com que se refazem peças de vestuário cuja matéria prima tornou-se escassa ou inacessível; são gírias que se agregam a velhos contos; são lendas reinterpretadas; é o automóvel e o avião substituindo o cavalo e a carruagem em narrativas tradicionais; é a fotografia substituindo a escultura do ex-voto etc (BENJAMIN, 2011, p. 2, grifo do autor).
}

Benjamin ainda enumera as seguintes características: a espontaneidade, à medida que os fatos folclóricos não são institucionalizados por meio de decretos e portarias, mas nascem na comunidade onde seu aprendizado se dá por meio da convivência, "de forma quase inconsciente e progressiva" ao contrário do que se aprende nas escolas de forma sistemática.

A funcionalidade do fato folclórico tem a ver com a noção de que estas manifestações exercem uma função nos sistemas culturais que integram, não constituindo fatos isolados, devendo ser entendidas dentro de um contexto social, econômico e político.

Finalmente, a ideia de regionalidade, uma vez que a manifestação folclórica é localizada, isto é, própria de uma comunidade, localidade, vila ou povoado. Ainda que um mesmo tipo de manifestação possa ser encontrado em diferentes localidades muitas vezes distantes, se analisarmos suas ocorrências, veremos que se trata de uma variante e que suas origens são comuns. "É regional e atualizado na ocorrência das variantes, que são o resultado da criatividade do portador do folclore e de sua comunidade" (BENJAMIN, 2011, p. 2).

Apesar dos avanços na definição do campo e melhor caracterização do que se entende por folclore nos dias de hoje, a materialidade nos estudos na área continua vinculada em sua maioria, aos eventos de cunho religioso ou festivo, ritos, danças e celebrações. A vida cotidiana, "a casa e a indumentária", colocados por Amaral $(1976$, p. 57) como uma categoria específica de sua classificação para os fatos folclóricos, ainda é pouco abordada pelos acadêmicos com interesse em cultura popular. Tomemos como exemplo o XVI Congresso Brasileiro de Folclore realizado em Florianópolis (ANAIS eletrônicos, 2013) em 2013 (Gráfico 2).

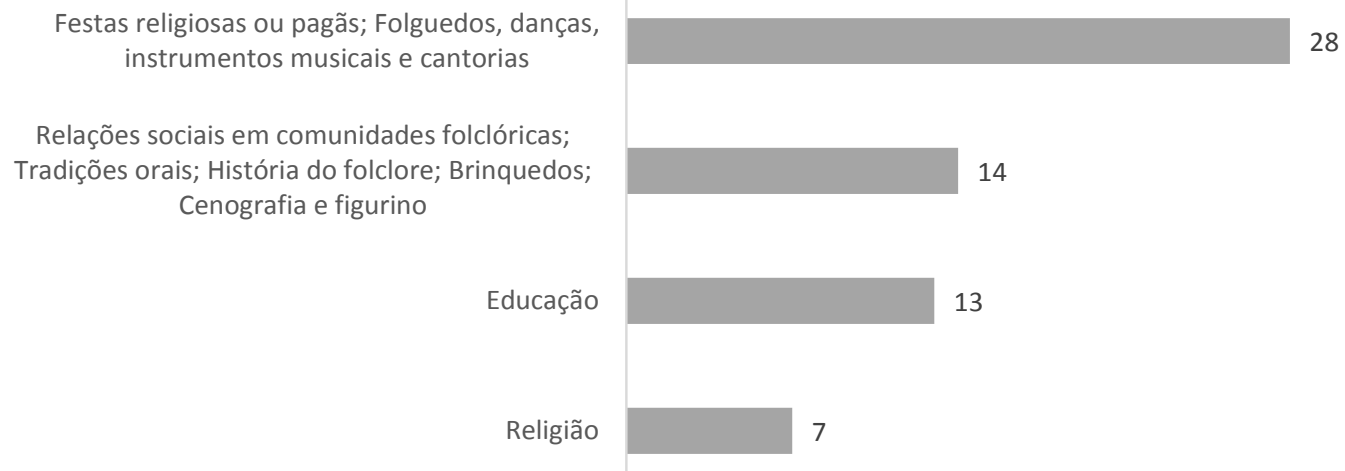

Gráfico 2. Temas dos trabalhos apresentados no XVI Congresso Brasileiro de Folclore, 2013. Elaborado pela autora em 2015. 
Dentre os trabalhos apresentados, festas religiosas ou pagãs, folguedos, danças, instrumentos musicais e cantorias associados a estas celebrações foram os temas predominantes, abordados 28 vezes; relações sociais em comunidades folclóricas, tradições orais, história do folclore, brinquedos, cenografia e figurino no teatro de folclore aparecem 14 vezes; a relação do folclore com a educação também ganha atenção dos pesquisadores, aparecendo em 13 trabalhos; religião é o tema de 7 artigos. Nenhum trabalho trata da casa ou do cotidiano, seus objetos e significados.

Além das discussões acerca da caracterização do folclore, duas outras questões persistem ao redor das manifestações da cultura popular: a primeira diz respeito aos vetores de forças aos quais se submete a cultura popular, tanto do ponto de vista político quanto econômico, em relação ao seu processo de mercantilização; a segunda diz respeito às abordagens sobre cultura popular, historicamente situadas entre uma visão romântica do folclore e a tendência a estigmatizá-lo como resíduo de uma sociedade.

Com relação à primeira questão, retomemos a Carta do Folclore Brasileiro de 1995 que, dividida em quinze capítulos, trata, como dito anteriormente, de definir o campo e estabelecer critérios e recomendações para a os estudos da área além de ressaltar a importância da documentação sobre o folclore, sua preservação e disponibilidade.

O capítulo VII, Evento, traz a questão da divulgação e promoção de eventos em relação ao calendário das localidades onde estes acontecem, e recomenda "respeitar os interesses dos representantes da cultura popular nas decisões relacionadas à dinâmica de suas manifestações, sem atitudes paternalistas nem imposição de modelos alheios ao próprio folclore" (CARTA, 1995). Mais à frente, no Capítulo XIV Hierarquias, recomenda que se atue "junto às autoridades religiosas, políticas, policiais e educacionais no sentido do reconhecimento, prestígio e respeito às várias formas populares de expressão cultural" (CARTA, 1995, p. 5).

Observando estas duas recomendações, fica clara a relação conflituosa entre os agentes das manifestações populares, pertencentes às camadas sociais subalternas e as autoridades representantes das esferas de poder da sociedade na qual se inserem, a ponto de se ter que recomendar respeito às formas de expressão popular.

Não se pode negar que "a diferença de classes implica a existência de concepções de mundo que se contrapõem" (AYALA, 1987, p. 51). O ponto em questão é que esta contraposição se dá de modo desequilibrado, entre classe dominante e dominada, com o autoritarismo da primeira sobre a segunda, entre governo e povo ou ainda elite e povo, numa relação desigual de poder (CHAUí, 1986).

Ao se recomendar que não sejam impostos modelos alheios ao próprio folclore, a Carta evidencia a desigualdade na relação entre aqueles que dominam, ou seja, instituições religiosas, políticas, policiais e educacionais, e aqueles dominados, o povo.

No capítulo VIII, a Carta se refere à relação entre folclore e turismo, e afirma:

Reconhece-se que a relação folclore e turismo é uma realidade. O turismo pode atuar como divulgador do folclore e como fonte de recursos para o crescimento da economia local, o que pode significar melhoria da qualidade de vida das camadas populares. Esta relação, porém, precisa ser avaliada no sentido de resguardar os agentes da cultura popular das pressões econômicas e políticas (CARTA, 1995, p. 4).

Neste ponto é possível identificar outro vetor de força sobre as classes subalternas, que se dá pelo viés econômico, não somente pelo cultural. Parece-nos indissociável o produto da cultura popular, ora artesanal 
e autônomo, das pressões políticas e econômicas das poderosas ferramentas do mercado globalizado. Não se pode falar em produção da cultura popular sem se pensar também em circulação e consumo, componentes da estratégia de mercado (CANCLINI, 1983).

A relação dos fatos folclóricos com as forças socioeconômicas do contexto capitalista no qual estão inseridos revela uma relação desigual de poder. As manifestações da cultura popular, tanto do ponto de vista econômico, quanto simbólico, tendem a trazer "valores estranhos ao status quo dos setores hegemônico da sociedade" em que se inserem. Mas são prontamente absorvidas e vinculadas à estrutura de classes, à cultura e à ideologia dominantes (AYALA, 1987, p. 51).

Canclini (1983), na introdução de seu estudo sobre as culturas populares e o capitalismo, pontua a problemática da mercantilização da cultura onde a visão estratégica do mercado enxerga os produtos produzidos pelo povo e não quem os produz. Para o autor, "o popular é o outro nome do primitivo: um obstáculo a ser suprimido ou um novo rótulo pertencente a mercadorias capazes de ampliar as vendas a consumidores descontentes com a produção em série" (CANCLINI, 1983, p. 11).

O autor cita as práticas dos turistas que, ao comprar para decorar seu apartamento um artefato de uma cerimônia selvagem, por exemplo, está na verdade, em sua opinião, evidenciando a superioridade de sua sociedade por meio da aquisição daquele souvenir, fruto da possibilidade que tem, graças ao seu poder aquisitivo, de viajar a lugares exóticos (CANCLINI, 1983, grifo do autor).

A tese de Canclini está fundamentada na concepção de que o capitalismo se apropria das culturas populares, reestruturando-as, reorganizando o significado e a função dos seus objetos e das suas crenças e práticas. Segundo ele, as classes dominantes desestruturam as culturas étnicas, nacionais e de classe, reorganizando-as num sistema unificado de produção simbólica que é correlata à multinacionalização do capital. Sobre isso Bosi cita: "O consumidor culto é um voyeur enfastiado, um perverso" (1982, p. 330, grifo do autor).

A segunda questão reside nas abordagens sobre cultura popular, historicamente situadas entre a "romantização", uma visão romântica do folclore, e a "fossilização", a tendência a estigmatizá-lo como resíduo de uma sociedade. (BOSI,1992, p. 323). O autor explicita o fenômeno de imposição de valores da cultura de massa sobre a cultura popular e as diferentes posturas dos eruditos em relação aos fenômenos populares.

Considerando o termo cultura como "uma herança de valores e objetos compartilhada por um grupo humano relativamente coeso" (BOSI, 1982, p. 309), o autor faz um registro analítico das diversas formas de culturas que não podem ser entendidas como isoladas, a saber, a cultura erudita, a cultura criadora, a cultura de massas e a cultura popular.

A cultura erudita (universitária) brasileira é aquela centralizada no sistema educacional, na academia. A cultura criadora (extrauniversitária) é individualizada de escritores, compositores, artistas plásticos, dramaturgos, cineastas, enfim, intelectuais que não vivem dentro da universidade. A cultura de massas ou cultura para as massas - que, pela sua íntima imbricação com os sistemas de produção e mercado de bens de consumo, acabou sendo chamada pelos intérpretes da Escola de Frankfurt de indústria cultural ou cultura de consumo-, pode ser entendida como o consumo de bens simbólicos através dos meios de comunicação de massa. Finalmente a cultura popular, basicamente iletrada, corresponde aos mores 
materiais e simbólicos do homem rústico, sertanejo ou interiorano, e do homem pobre suburbano ainda não de todo assimilado pelas estruturas simbólicas da cidade moderna, ao que ele chama de Folclore (BOSI, 1992).

O autor traça algumas relações entre a cultura popular e as culturas de massa e erudita, indicando combinações de aspectos que operam entre si. Refere-se à cultura de massas que, com o poder econômico dos meios de comunicação, parece ter reduzido as manifestações da cultura popular em folclore para turismo. Devido à crescente penetração de certos programas de rádio e TV junto às classes pobres com suas reportagens popularescas, o autor reflete: "tal é a aparência de modernização que cobre a vida do povo em todo o território brasileiro, que, à primeira vista, parece não ter sobrado mais nenhum espaço próprio para os modos de ser, pensar e falar, em suma, viver, tradicional-populares" (BOSI, 1992, p. 328).

Atualizando o argumento de Alfredo Bosi para os dias atuais, o mesmo fenômeno acontece em relação à internet, sobretudo às redes sociais, confirmando o que autor designa por uma "investida técnico-econômica violenta do sistema capitalista". O que se observa é que "o povo assimila, a seu modo, algumas imagens da televisão, alguns cantos e palavras do rádio, traduzindo os significantes no seu sistema de significados" (BOSI, 1992, p. 328), dando origem quem sabe, a uma nova situação de cultura, apropriando-se do termo utilizado por Brandão (1982) para configurar a interpenetração de influências de outras formas de cultura.

Aquilo que vimos existir como folclórico não existe em estado puro. Existe no interior de uma cultura, de culturas que se cruzam a todo momento e que representam categorias sociais de produtores dos modos de "sentir, pensar e fazer". Talvez mais certo do que dizer até que folclore é um tipo de cultura, [...] seja dizer que o folclore é uma situação de cultura. É um momento que configura formas provisoriamente anônimas de criação: popular, coletivizada, persistente, tradicional e reproduzida através dos sistemas comunitários não-eruditos de comunicação do saber. (BRANDAO, 1982, p. 56).

Com respeito à relação da cultura erudita com a cultura popular, Alfredo Bosi afirma que isto se dá de duas maneiras distintas: ou a cultura erudita ignora ou se debruça interrogativa e encantada sobre a cultura popular "diversa e oposta à frieza, secura e inibição peculiares ao intelectualismo ou à rotina universitária" (BOSI, 1992, p. 330).

A respeito dessa relação, pondera que podem nascer frutos muito diferentes entre si, "que vão do mais cego e demagógico populismo, [...] à mais bela obra de arte elaborada em torno de motivos populares, como a música de Villa- Lobos, o romance de Guimarães Rosa, a pintura de Portinari e a poesia negra de Jorge de Lima" (BOSI, 1992, p. 331). E acrescenta: "só há uma relação válida e fecunda entre o artista culto e a vida popular: a relação amorosa" (BOSI, 1992, p. 331).

Sobre a relação dos estudos sociológicos no campo das culturas populares, tanto Alfredo Bosi (1992), quanto Chauí (1986) e Canclini (1983), seguem a mesma direção. Identificam-se duas tendências igualmente perniciosas nesta relação, ou seja, de um lado os estudos convencionais que rotulam as manifestações populares de residuais, e estigmatizam a cultura popular como "fóssil correspondente a estados de primitivismo, atraso, demora, subdesenvolvimento" cujo futuro é o "desaparecimento desses resíduos, e a integração de todos os seus sujeitos nas duas formas institucionais mais poderosas: a cultura para as massas e a cultura escolar" (BOSI, 1992, p. 323). Em outro extremo, os trabalhos da vertente românticonacionalista (ou romântico-regionalista, ou romântico-populista) que tomam por valores eternamente válidos os transmitidos pelo folclore, recusando seus vínculos com a cultura de massa e a cultura erudita, e 
identifica as expressões grupais com o que ele chama de "mítico espírito do povo".

Canclini (1983) repudia o que chama de "armadilha da idealização romântica" que "concebe o povo como uma totalidade hegemônica e autônoma, cuja criatividade espontânea seria a mais alta expressão dos valores humanos e o modelo de vida ao qual deveríamos regressar" (CANCLINI, 1983, p. 44).

Chauí (1986) também nos aponta o perigo em incorrer no que chama de perspectivas Romântica ou Ilustrada do conceito de cultura popular e reforça a origem do problema na herança histórica de uma sociedade de classes.

\footnotetext{
A perspectiva romântica supõe a autonomia da cultura popular, a ideia de que, para além da cultura ilustrada dominante, existiria uma outra cultura "autêntica", sem contaminação e sem contato com a cultura oficial e suscetível de ser resgatada por um Estado novo e por uma Nação nova. A perspectiva llustrada, por seu turno, vê a Cultura Popular como resíduo morto, como museu e arquivo, como o 'tradicional' que será desfeito pela 'modernidade', sem interferir no próprio processo de 'modernização'. Românticos e llustrados pensam a cultura Popular como totalidade orgânica, fechada sobre si mesma, e perdem o essencial: as diferenças culturais postas pelo movimento históricosocial de uma sociedade de classes (CHAUí, 1986, p. 24, grifo da autora).
}

Os estudos em folclore, independentemente da intenção do pesquisador, sempre haverão de pontuar as diferenças culturais, uma vez que a cultura é um conceito que só existe a partir do olhar do outro. No entanto, atendamos ao chamado de Bosi que nos conclama a "cavar uma teoria da aculturação que exorcize os fantasmas elitista e populista, ambos agressivamente ideológicos e fonte de arraigados preconceitos" (BOSI, 1992, p. 324).

\subsection{Identidade, memórias afetivas e objetos do cotidiano}

\footnotetext{
Como todos nós sabemos, a identidade de qualquer pessoa é constituída a partir de vivências afetivas e culturais: das músicas e das estórias que ela escuta em criança; dos jogos que aprende nas ruas e na escola; do contato com a natureza que tem a sua volta; sua luz, sua temperatura, seu cheiro; do nível de cordialidade que permeia a relação das pessoas com quem convive; da forma como se dá com as várias etnias que compõem o seu povo; da língua que escuta dentro e fora de casa, melhor dizendo, das formas de apropriação do código comum, tal como ele se apresenta em suas muitas variações (ESCOREL, 2000, p. 26).
}

Um seminário sobre a noção de identidade, coordenado por Lévi-Strauss em 1977, trazia a seguinte conclusão: "a identidade é uma entidade abstrata sem existência real, muito embora fosse indispensável como ponto de referência" (ORTIZ, 1985, p. 137).

Pollak (1992, p. 204) recorrendo à psicologia, define três elementos essenciais na construção da identidade: 1) a unidade física, isto é, o próprio corpo no nível individual, ou o pertencimento a um grupo no nível coletivo; 2) a continuidade no tempo físico, moral e psicológico; 3) o sentimento de coerência que unifica os diferentes elementos que formam o indivíduo.

Na concepção sociológica, Hall (2000) conceitua a identidade como aquela "formada na 'interação' entre o eu e a sociedade. O sujeito ainda tem um núcleo ou essência interior que é o 'eu real', mas este é formado e modificado num diálogo contínuo com os mundos culturais 'exteriores' e as identidades que esses mundos oferecem." Argumenta que esta espécie de sutura "estabiliza tanto os sujeitos quanto os mundos culturais 
que eles habitam" (HALL, 2000, p. 11, grifos do autor).

Entretanto, graças a profundas alterações sociais e políticas ocorridas no século XX, devido à aceleração do processo de "globalização", surge o que o autor chama de sujeito pós-moderno, conceitualizado como não tendo uma identidade fixa, essencial ou permanente.

\footnotetext{
A identidade torna-se uma 'celebração móvel': formada e transformada continuamente em relação às formas pelas quais somos representados ou interpelados nos sistemas culturais que nos rodeiam. [...] O sujeito assume identidades diferentes em diferentes momentos, identidades que não são unificadas ao redor de um 'eu' coerente. Dentro de nós há identidades contraditórias, empurrando em diferentes direções, de tal modo que nossas identificações estão sendo continuamente deslocadas. [...] À medida em que os sistemas de significação e representação cultural se multiplicam, somos confrontados por uma multiplicidade desconcertante e cambiante de identidades possíveis, com cada uma das quais poderíamos nos identificar - ao menos temporariamente (HALL, 2000, p. 13, grifo do autor).
}

As alterações estruturais de tempo e espaço que alteram o cenário mundial e por consequência o sujeito, como resultado das tensões entre identidades "global" e "local", levantam as discussões em torno da "crise da identidade" nas ciências sociais uma vez que o sujeito pós-moderno parece ter rompido com a noção de continuidade e coerência citadas por Pollak (1992).

Outro ponto colocado por Hall (2000) diz respeito à noção de identidade nacional, onde o autor argumenta que isto não é alguma coisa com a qual nascemos, e sim uma ideia formada e transformada no "interior da representação. [...] A nação não é apenas uma entidade política mas algo que produz sentidos - um sistema de representação cultural" (HALL, 2000, p. 49, grifo do autor).

Independentemente de se tratar de um país de dimensões continentais e formação multicultural, onde, portanto, a ideia de identidade nacional já se coloca improvável devido a sua condição plural, a principal questão em relação à criação de uma identidade nacional - ou identidades regionais - no caso do Brasil, reside na fatalidade de um discurso que se dá de modo impositivo por setores hegemônicos da sociedade e do Estado, da Igreja e da mídia, na formulação de símbolos alheios à realidade popular. Segundo Ortiz (1985, p. 138) este é um "discurso de segunda ordem" pois não se dá no "nível da vivência" e sim no "nível da ideologia".

Os agentes sociais e econômicos no comando da sociedade se apropriam de elementos da sua criação para resignificá-los de acordo com interesses estranhos à coletividade. Um exemplo disto é o que se observa em relação às festas de peão de boiadeiro no interior do estado de São Paulo, onde as antigas disputas de finais de semana entre peões de fazendas foram convertidas em espetáculos esportivos midiáticos com premiações e patrocínios milionários. A "identidade híbrida" citada por Hall (2000), neste caso, se dá em relação a uma imagem fabricada pelo negócio dos rodeios paulistas, responsável pela criação de uma nova cultura com a qual se identificam milhares de jovens em São Paulo, por meio de suas músicas, sua indumentária e um determinado modo de agir e falar, símbolos criados pela indústria cultural.

Por outro lado, o fenômeno da identidade pode ser observado em manifestações espontâneas que ocorrem no interior de uma determinada população, ou seja, fatos folclóricos que emergem da criação popular anônima ou coletivizada, menos influenciados - ainda que temporariamente - das pressões políticas, ideológicas ou econômicas impostas pelas esferas dominantes. Os fatos folclóricos operam aqui como dispositivos de identificação, gerando um sentimento de pertencimento. Em uma passagem de seu livro O que é folclore, Brandão (1982) ilustra esta ideia ao relatar a fala de um estrangeiro assistindo a uma 
festividade folclórica em Pirenópolis, interior de Goiás: "as pessoas, parece que estão se divertindo [...] mas elas fazem isso para não esquecer quem são" (BRANDAO, 1982, p. 11).

O fato folclórico, portanto, pode ser compreendido como a manifestação da memória submersa de uma sociedade, com o que o sujeito pós-moderno constrói uma identidade possível.

A noção de identidade enquanto uma celebração móvel dialoga com a definição de folclore enquanto "situação de cultura" (BRANDÃO, 1982, p. 45), especificamente em relação à continuidade de uma tradição, onde novos fatos se inserem sem que haja uma ruptura com o passado. Novas representações são formuladas, construídas sobre este passado.

Para que se tenha acesso ao passado de um grupo social, os indivíduos daquele grupo recorrem à sua memória coletiva. Compreende-se memória como "a capacidade humana de reter fatos e experiências do passado e retransmiti-los às novas gerações através de diferentes suportes empíricos (voz, música, imagem, textos etc.)" (SIMSON, 2003, p. 14).

Segundo Halbwachs (1990), existe uma memória individual, onde as lembranças podem se organizar em torno de uma pessoa definida, que as considera de seu ponto de vista, e a memória coletiva onde as memórias individuais distribuem-se "no interior de uma sociedade grande ou pequena, de que elas são outras tantas imagens parciais" (HALBWACHS, 1990, p. 55). O conceito de memória coletiva de Halbwachs (1990) traz a ideia de "pontos de contato entre diversas memórias individuais de um grupo que, concordando entre si, reconstrói a lembrança sobre um fundamento comum" (HALBWACHS, 1990, p. 34). Nota-se um predomínio do social sobre o individual na obra do autor, que vai estudar a memória como um quadro social e não psíquico. Enquanto a história é uma, as memórias coletivas são várias. "Toda memória coletiva tem por suporte um grupo limitado no espaço e no tempo" (HALBWACHS, 1990, p. 86). A história se atém ao diferente, ao marcante, ao fato pontual; já a memória se atém às similitudes. "O grupo, no momento em que considera seu passado, sente acertadamente que permaneceu o mesmo e toma consciência de sua identidade através do tempo" (HALBWACHS, 1990, p. 87).

Pollak (1989) traz a noção de memórias subterrâneas para se referir às memórias reprimidas das camadas populares em oposição à memória oficial ou nacional. Segundo o autor, as memórias subterrâneas são memórias marginalizadas que foram reprimidas, que "prosseguem seu trabalho de subversão no silêncio e de maneira quase imperceptível afloram em momentos de crise em sobressaltos bruscos e exacerbados." (POLLAK, 1989, p. 4). É importante notar que, diferentemente do esquecimento, que é a contrapartida da lembrança, as memórias subterrâneas são latentes, operam como mecanismos de resistência à repressão das forças de controle social ou político.

Essas memórias subterrâneas geralmente se encontram muito bem guardadas no âmago de famílias ou grupos sociais dominados nos quais são cuidadosamente passadas, de geração a geração, através de relatos, músicas, quadras poéticas, ocasiões em que os membros do grupo se auxiliam mutuamente na tarefa de relembrar, cada um contribuindo com detalhes que detonam processos rememorativos dos outros participantes. É o que denominamos uma construção compartilhada da memória (SIMSON, 2003, p. 15).

Na construção compartilhada da memória surgem as formas coletivas de criação e recriação, compõe-se um processo de identificação daquele grupo social que se configura e reconfigura cada vez que se conta um conto, que se canta uma cantiga, que se acende um fogão para o preparo da refeição. A memória, assim como a identidade, não é rígida nem tampouco imutável. Trata-se de um contínuo que se modifica 
em constante processo de transformação.

A lembrança é em larga medida uma reconstrução do passado com a ajuda de dados emprestados do presente, e além disso, preparada por ouras reconstruções feitas em épocas anteriores e de onde a imagem de outrora manifestou-se já bem alterada (HALBWACHS, 1990, p. 71).

Outro ponto relevante sobre a memória diz respeito ao seu caráter de fuga, evasão de um presente que solicita intensamente o sujeito pós-moderno, como ilustra Éclea Bosi (1994) em seu livro Memória \& sociedade: lembrança de velhos, no qual a autora entrevista homens e mulheres idosos que hoje não trabalham mais e que dedicam um tempo "socialmente permitido" para rememorar e reconstruir suas histórias. A este quadro, segundo a autora, contrapõe-se o adulto ativo, que, demasiadamente ocupado pelas tarefas do dia a dia, vê o ato de rememorar como uma fuga.

Entretido nas tarefas do presente, não procura habitualmente na infância imagens relacionadas com sua vida cotidiana; quando chega a hora da evocação, esta é, na realidade, a hora do repouso, o relaxamento da alma, desejo breve mas intenso de evasão. O adulto ativo não se ocupa longamente com o passado; mas quando o faz, é como se este lhe sobrevivesse em forma de sonho. Em suma, para o adulto ativo, vida prática é vida prática, e memória é fuga, arte, lazer, contemplação (BOSI, E., 1994, p. 60).

Desta maneira, podemos destacar alguns pontos de convergência entre os conceitos de folclore, identidade e memória popular: seus limites são maleáveis e imprecisos; reescrevem-se a cada ocorrência em processos contínuos de criação e recriação; operam como mecanismos de continuidade e coerência ainda que em constante mutação; trazem em seu interior a ideia de pertencimento e referência diante de uma situação de marginalidade bem como uma noção de fuga frente às pressões a que se submete o sujeito pós-moderno.

Bergson afirma que "é do presente que parte o chamado ao qual a lembrança responde" (BERGSON, 1959, p. 886), a que Halbwachs complementa: "a lembrança é uma imagem construída pelos materiais que estão, agora, à nossa disposição, no conjunto de representações que povoam nossa consciência atual" (HALBWACHS, 1990, p. 55). Diante disso podemos afirmar que os objetos do cotidiano desempenham um papel relevante na construção das identidades, nas vivências afetivas e nos relatos de memória.

Halbwachs ressalta a relação simbólica entre o sujeito e as sociedades, visíveis ou não, por meio dos objetos: "nossa cultura e nossos gostos aparentes na escolha e na disposição desses objetos se explicam em larga medida pelos elos que nos prendem sempre a um grande número de sociedades, sensíveis ou invisíveis" (HALBWACHS, 1990, p. 132).

O autor cita a capacidade dos objetos de carregarem nossa marca e das pessoas com que convivemos no passado, reforçando a relação do indivíduo e suas memórias com as coisas que o cercam.

\footnotetext{
Por que nos apegamos aos objetos? Por que desejamos que não mudem, e continuem a nos fazer companhia? Afastamos toda consideração de comodidade ou de estética. Nosso entorno material leva ao mesmo tempo nossa marca e a dos outros. Nossa casa, nossos móveis e a maneira segundo a qual estão dispostos, o arranjo dos cômodos onde vivemos, lembram-nos nossa família e os amigos que víamos geralmente nesse quadro (HALBWACHS, 1990, p. 131).
}

Baudrillard (2008) vai estudar o simbolismo dos objetos por meio de uma análise de "como os objetos são vividos", ou seja, a que necessidades, além das funcionais, estes objetos atendem, "que estruturas mentais misturam-se às estruturas funcionais e as contradizem, sobre que sistema cultural, infra ou transcultural, é fundada a sua cotidianidade vivida" (BAUDRILLARD, 2008, p. 10). De acordo com sua tese, os objetos 
estão ligados diretamente aos indivíduos uma vez que são portadores de significados que operam como mediadores das relações humanas. Ao autor não interessa analisar os objetos de acordo com sua função, mas por meio dos "processos pelos quais as pessoas entram em relação com eles e da sistemática das condutas e das relações humanas que desses resulta" (BAUDRILLARD, 2008, p. 10). Com relação ao aspecto funcional dos objetos, o autor compreende o termo não apenas por sua finalidade prática, mas também pelo seu caráter simbólico dentro de um determinado sistema cultural.

O primeiro sistema cultural do qual faz parte o indivíduo é composto pela família e o espaço habitado por ela, o que configura os códigos que vão perdurar em sua memória ainda que, com o tempo, estes sejam resignificados.

Aquilo que faz a profundidade das casas de infância, sua pregnância na lembrança, é evidentemente esta estrutura complexa de interioridade onde os objetos despenteiam diante dos nossos olhos os limites de uma configuração simbólica chamada residência (BAUDRILLARD, 2008, p. 23).

Sobre o simbolismo dos objetos do cotidiano presentes no interior das residências, e seu papel na vida dos indivíduos, outro trabalho a nos chamar a atenção é a pesquisa desenvolvida pelo psicólogo Mihaly Csikszentmihalyi e o sociólogo Eugene Rochberg-Halton, na década de 1980, na região de Chicago, que buscava investigar o valor dos objetos de arte na vida das pessoas. Cerca de oitenta residências foram visitadas, porém os pesquisadores se depararam com um resultado inesperado ao perceberem que a arte tinha um papel insignificante em suas vidas, enquanto a maioria dos entrevistados demonstrou forte apego a artefatos domésticos sem qualquer valor estético. Além de carregados de significados, estes artefatos pareciam trazer propósito a suas vidas. Os resultados demonstraram que cada casa tinha um "ecossistema simbólico", ou uma rede de objetos ligados a significados que traziam sentido à vida de seus moradores.

Uma velha xícara, um vaso de flor, um anel ou um retrato de família tem um poder simbólico uma vez que produz um senso de ordem em nossa mente. O sentido de nossas vidas privadas está edificado nos objetos domésticos (CSIKSZENTMIHALYI, 1991, p. 34, tradução nossa).

A pesquisa de Damazio (2005) também aponta na direção da relevância dos objetos como símbolos na vida das pessoas, mas o que interessa à pesquisadora são os artefatos que fazem bem lembrar, a que chama de artefatos de memória. A autora parte de relatos de memórias individuais contendo determinados objetos, em função de acontecimentos dos quais estes fizeram parte, argumentando que os artefatos participam das relações humanas. Para Damazio, os atributos dos artefatos de memória não estão na qualidade estética, mas na qualidade dos acontecimentos dos quais participam (DAMAZIO, 2005). Em seu estudo, investiga os artefatos de memória e suas relações afetivas com os entrevistados, organizandoos em categorias de ações promovidas por estes artefatos, bem como pela natureza das vivências que testemunham, para posteriormente traduzir esses temas em conceitos para novos designs de produtos memoráveis em seu laboratório de pesquisas na Pontifícia Universidade Católica do Rio de Janeiro, PUC-RJ, a partir da ideia de que "por meio de suas particularidades físicas os artefatos se materializam e participam de nossas vidas [...] e são reconhecidos" (DAMAZIO, 2005, p. 3).

Desta forma, é possível afirmar que os artefatos são símbolos de uma cultura e carregam significados inerentes a ela, uma vez que participam ativamente de nossas experiências e habitam nossas memórias ao lado dos fatos de que tomaram parte um dia. 


\begin{abstract}
Mais que um sentimento estético ou de utilidade, os objetos nos dão um assentimento à nossa posição no mundo, à nossa identidade. Mais que da ordem e que da beleza, falam à nossa alma em sua doce língua natal. $O$ arranjo de sala cujas cadeiras preparam o círculo das conversas amigas, como a cama prepara o repouso e a mesa de cabeceira os instantes prévios, o ritual antes do sono. A ordem desse espaço povoado nos une e nos separa da sociedade: é um elo familiar com sociedades do passado, pode nos defender da atual revivendo-nos outra. Quanto mais voltados ao uso cotidiano, mais expressivos são os objetos: os metais se arredondam, se ovalam, os cabos de madeira brilham pelo contato com as mãos, tudo perde as arestas e se abranda. [...] Daí vem a timidez que sentimos ao entrarmos em certos quartos em que os objetos nos revelam quem é seu dono (BOSI, E., 1994, p. 441).
\end{abstract}

Os critérios que uma determinada pessoa utiliza para escolher os objetos que a rodeiam bem como o modo como dispõe estes objetos à sua volta, falam muito sobre ela, sobre sua história e sobre sua identidade.

\title{
1.5 As questões da identidade na prática do design
}

Na contramão do processo de imposição cultural advinda dos mercados dominantes, ou em resposta a ele, nota-se recorrente na história do design no Brasil o interesse por parte de designers nas questões acerca das identidades brasileiras. Bonsiepe (2011, p. 45) confirma esta percepção ao afirmar que "identidade e globalização ocupam uma posição central no discurso atual do design".

Voltemos à década de 1960 e a Aloísio Magalhães. Um dos maiores nomes do design brasileiro do século XX, Aloísio defendeu a cultura do país como o ponto de partida para se criar uma identidade do design brasileiro, além de uma referência para seu desenvolvimento econômico e social. Trabalhou pela preservação de um acervo material representativo da identidade nacional, pois acreditava que se os bens culturais brasileiros fossem preservados e estivessem disponíveis para fruição e consulta, certamente serviriam como base para a construção do nosso futuro, na linha de uma proposta alternativa e original, que evidenciasse os traços distintivos da nação no confronto com outras culturas (ESCOREL, 2000).

Nas discussões acerca do design de produtos para exportação, Magalhães defendia a criação de um produto autêntico, criticando, à época, a política de se criar um design de exportação. Ele afirmava ser necessário criar-se um sentimento global dentro do país, pois, a partir daí, o produto estaria carregado de autenticidade, com capacidade de competir no cenário mundial. E para tanto, sugeria a formação de quadros e estímulos dentro da realidade brasileira de nossas necessidades (REDIG, 1989).

Nessa mesma época, outra personalidade na arquitetura e no design no Brasil fez da valorização da cultura brasileira uma marca em seu trabalho. Com foco no repertório popular, Lina Bo Bardi, italiana e ícone modernista da arquitetura, torna-se uma colecionadora de objetos de arte popular e defensora dos valores da cultura nativa brasileira. Sua relação com o assunto remonta ao período que ela passaou na Bahia, onde conhece profundamente o artesanato brasileiro. Valorizando a cultura nativa brasileira em detrimento da herança europeia, confere brasilidade ao seu design de mobiliário: "Nós temos esta convicção e estamos persuadidos de que uma cadeira caipira de grumixaba e taboa é mais moral e importante do que um divã de babados de estilo francês" (BARDI, 1949, p.37).

Por meio de sua convicção, que permeia seu trabalho, Lina nos incita a reexaminar a história recente do país de modo a fazer um balanço da civilização brasileira popular, mas alerta que "este balanço não é do 
folklore, sempre paternalisticamente amparado pela cultura elevada; é o balanço visto do outro lado, o balanço participante" (BARDI, 1994, p. 12, grifo da autora). Nota-se que a autora critica o caráter romântico da relação da cultura erudita, ou elevada, que ampara de modo paternal as manifestações da cultura popular, e nos convida de outro modo, a participar do fenômeno popular. E continua:

Procurar com atenção as bases culturais de um país (sejam quais forem: pobres, míseras, populares) quando reais, não significa conservar as formas e os materiais, significa avaliar as possibilidades criativas originais. Os materiais modernos e os modernos sistemas de produção tomarão depois o lugar dos meios primitivos, conservando, não só as formas, mas a estrutura profunda daquelas possibilidades (BARDI, 1994, p. 21, grifo da autora).

Mais recentemente, em 2009, a questão da identidade e da cultura popular como referência no design pode ser observada novamente na $9^{a}$ Bienal de Design Gráfico da Associação dos Designers Gráficos do Brasil - ADG/Brasil, onde, inserida entre as nove categorias do evento, destacou-se uma categoria intitulada "Popular, Vernacular e Regional", que procurara contemplar projetos inspirados nesse universo.

No catálogo da Bienal, Finizola (2009) conceitua os termos popular, vernacular e regional e apresenta suas diferentes características:

O popular abrange o universo de produtos industriais e culturais consumidos ou gerados pela grande massa da população. Não descartando também aqueles hábitos que foram inicialmente impostos pela cultura dominante e mais tarde incorporados na cultura local. [...] A utilização do termo vernacular é empregada para definir aqueles artefatos autênticos da cultura de determinada região, geralmente produzidos à margem do design oficial. [...] Assim, o design com influência do vernacular é aquele que provém diretamente das tradições culturais de cada povo, que são passadas adiante, de geração em geração, de maneira informal. [...] O regional configura especificamente uma tradição vinculada a um território que possui forte identidade cultural (FINIZOLA, 2009, p. 120).

Isoladamente, a palavra "vernáculo" designa uma língua nativa.

Antes do aparecimento da cultura impressa, as linguagens europeias eram consideradas línguas vernáculas, em contraste ao Latim e ao Grego oficial, usadas pelas classes instruídas. O termo vernacular sugere a existência de linguagens visuais e idiomas locais, que remetem a diferentes culturas (DONES, 2004, p. 2).

Vários termos são utilizados para se caracterizar o design vernacular: design alternativo, design improvisado, design popular, design espontâneo, design étnico. Independente da terminologia empregada, além do caráter não erudito ou não profissional do design vernacular, esse universo representa a inventividade de um povo frente as suas reais necessidades e às circunstâncias precisas de sua condição sócio cultural, por meio de soluções que podem ser vistas como fonte de referência para compreendermos as reais necessidades da sociedade e como ela lida com suas demandas. Neste sentido, conceitua Santos (2000), associando o termo à ideia de necessidades vitais:

Design espontâneo é a prática criativa de encontrar soluções funcionais, aplicáveis para resolver problemas concretos, num contexto de grave falta de recursos. É um tipo de design impulsionado exclusivamente pela necessidade vital para a sobrevivência (SANTOS, 2000, p. 2, tradução nossa).

Cristofaro acrescenta a ideia do design vernacular atuar como um instrumento de subjetivação e identidade, na produção de sentido.

Design Vernacular designa uma forma não-ortodoxa de Design e refere-se a soluções materiais ou visuais presentes no cotidiano que indicam uma profunda relação com a cultura local. Este termo tem origem na junção da palavra 
Design, no sentido de desenho, projeto ou desígnio, com a palavra Vernáculo que designa uma língua nativa. Deste modo, o Design Vernacular relaciona-se com a questão do gosto como faculdade humana e como instrumento ativo de subjetivação e identidade, devendo ser compreendido como um fenômeno social e cultural com capacidade de atuar na produção de sentido (CRISTOFARO, 2013, p. 1).

Voltemos à $9^{a}$ Bienal de Design Gráfico. Dentre os trabalhos desta categoria, é possível observar três abordagens diferentes sobre o tema: primeiramente, aqueles trabalhos que se apropriam ou fazem releituras de elementos da linguagem gráfica presentes neste universo, propondo novas aplicações e utilizações.
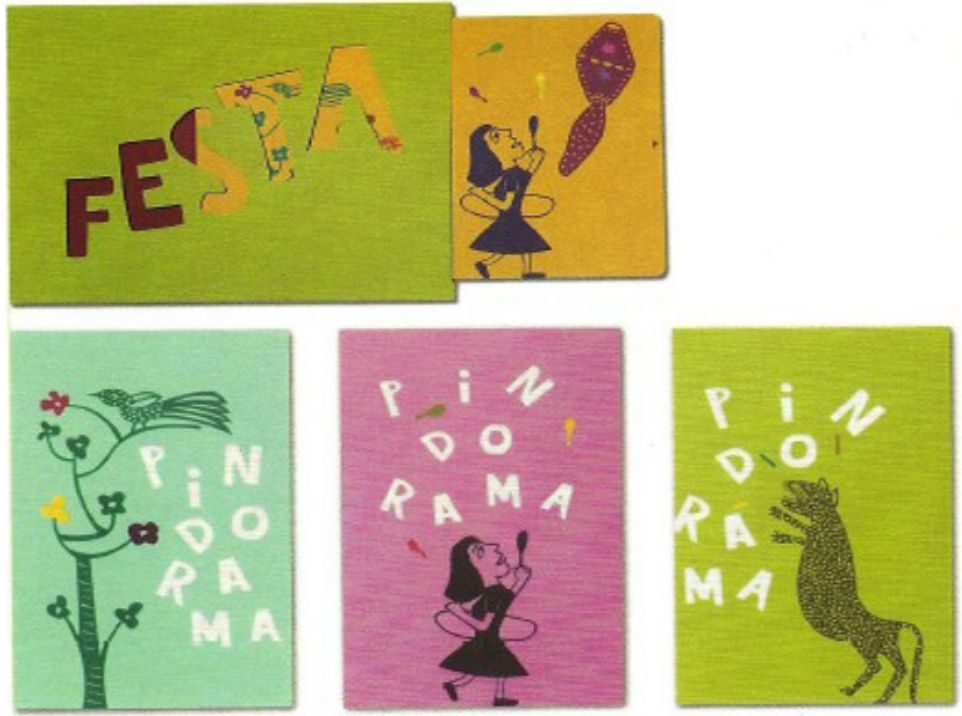

Figura 8. Identidade visual do Espaço Pindorama de Festas Infantis. Design: Rex Design. (Reproduzido de CONSOLO, 2009, p. 132)
Por exemplo, um cardápio que incorpora uma tipografia típica dos letreiramentos populares encontrados nos subúrbios das cidades; ou um projeto de identidade visual que se utiliza da estética dos cordéis resultante da técnica rudimentar da xilogravura (Figura 8), mas que incorpora novos elementos com um tratamento cromático incomum, ou mesmo uma janela vazada na capa do convite, na palavra "festa", de modo a se deixar entrever a ilustração embaixo.

Ainda nesse grupo de trabalhos é possível encontrarmos peças gráficas que se apropriam de materiais e técnicas de reprodução advindos do universo popular, como um suporte de impressão rústico como o papel kraft e outros similares, ou a técnica de impressão lambe-lambe por exemplo.

Num segundo grupo, aparecem trabalhos que se utilizam de registros de imagens, cores, texturas e formas, fragmentos de ambiente à nossa volta, como um acervo visual da materialidade cultural do nosso ambiente.

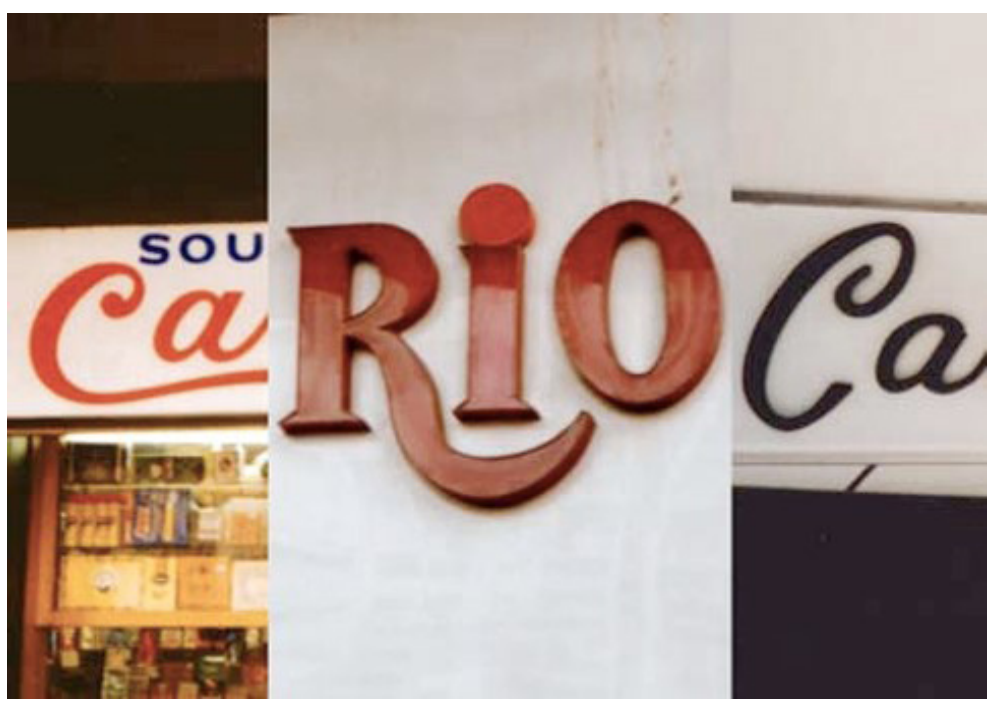

Figura 9. Postal Carioca, design de Bruno Porto. (Reproduzido de CONSOLO, 2009, p. 125)
Aqui podem ser vistos registros da produção efêmera do povo, ameaçada de extinção pela metamorfose das grandes cidades como, por exemplo, o postal Carioca (Figura 9), composto por fotografias de letreiros de fachadas do bairro de Copacabana e sua diversidade tipográfica, ameaçados de extinção pela prática recorrente nas grandes cidades de substituição do tradicional por novos modelos. 


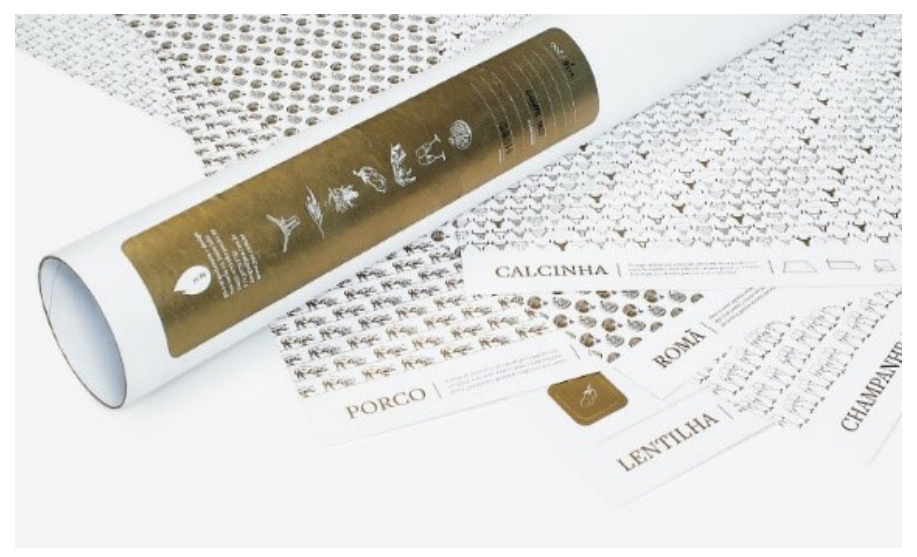

Figura 10. Brinde PS.2 2007/2008. Design ps.2 arquitetura + design. (Reproduzido de CONSOLO, 2009, p. 131)
E por último, aqueles projetos que não fazem referência visual à identidade, mas que a tratam conceitualmente, fazendo uma leitura de hábitos e comportamentos presentes em cada região, sem necessariamente se utilizar das linguagens visuais legitimamente populares (FINIZOLA, 2010). Neste sentido, temos o brinde autopromocional de final de ano da PS.2 arquitetura + design (Figura 10), cuja linguagem visual

é claramente distante do universo popular que o inspirou. A aproximação com o popular se dá por meio de sua temática: o brinde é composto por um kit contendo pôster, adesivos, envelopes e demais peças gráficas estampadas com motivos relacionados a hábitos populares como comer lentilha e carne de porco, usar roupa íntima colorida ou mandar oferendas para lemanjá, tradições típicas da noite de Réveillon.

Finizola (2009) comenta diante dos trabalhos selecionados para a 9a Bienal, que o design gráfico se inspira cada vez mais na cultura popular e cita o olhar atento do designer em captar a linguagem visual anônima das ruas.

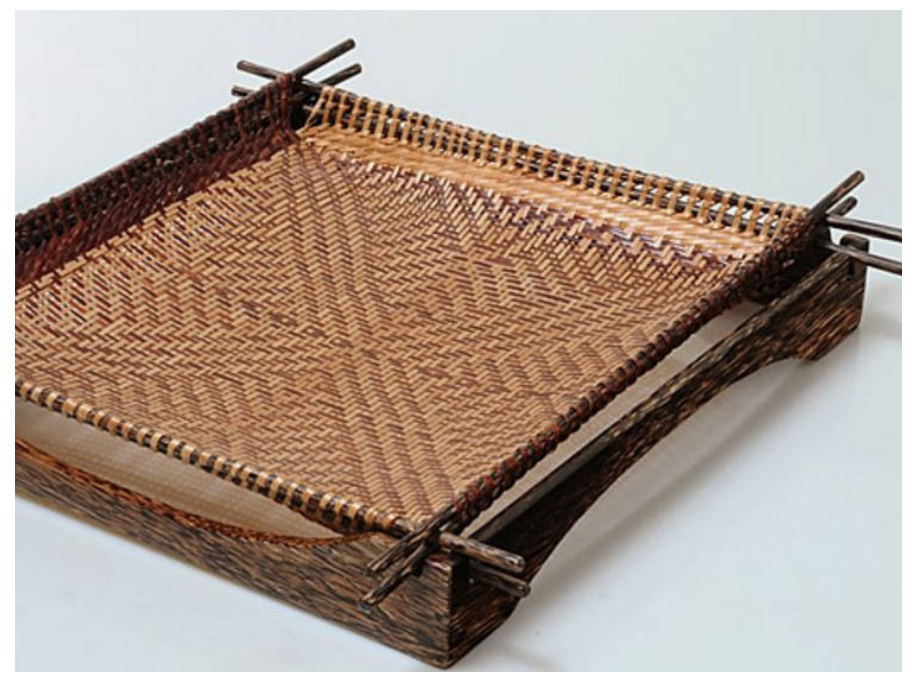

Figura 11. Cesta de pães do designer Luiz Galvão (FUCAPI, s/d.).
Ainda sobre a questão do interesse dos designers pela busca das raízes populares, Queluz (2008) nos chama atenção para iniciativas como a desenvolvida pelo Serviço Brasileiro de Apoio às Micro e Pequenas Empresas (Sebrae) que, através de programas que unem design e artesanato "tem feito um mapeamento do país buscando estimular, desenvolver e promover o artesanato brasileiro, apontando as vantagens e possibilidade futuras na aproximação entre essas duas áreas - design e artesanato" (2008, p. 25).

Nesta mesma direção podemos citar o Projeto Setorial desenvolvido em parceria pela Associação Brasileira de Exportação de Artesanato (Abexa) e pela Agência Brasileira de Promoção de Exportações e Investimentos (Apex-Brasil), que tem como objetivo promover as exportações e contribuir para melhorar e aumentar a inserção do artesanato brasileiro no mercado internacional; e a recente premiação da cesta de pães (Figura 11) do designer Luiz Galvão do Núcleo de Design Tropical da Amazônia da Fundação Centro de Análise, Pesquisa e Inovação Tecnológica (Fucapi) ${ }^{6}$ no prêmio Les Découvertes (As Descobertas) dedicado ao design ético na Feira Maison \& Objet, em 2013, em Paris, que explora a temática rústica regional por meio de seu desenho e materiais. Entrevistas temáticas "são entrevistas que se referem a experiências ou processos.

6 Vide site da instituição, cf. as referências bibliográficas deste trabalho. 


\section{Métodos para investigação da cultura visual e material caipira}


Por se tratar de um estudo interdisciplinar, que une design e folclore por meio da sua materialidade, os objetos do cotidiano das casas populares, a metodologia adotada possibilitou a união de diferentes áreas do conhecimento, de modo a elucidar este fenômeno cultural.

De modo geral, o procedimento utilizado nesta pesquisa baseou-se em ampliar o olhar do indivíduo para a sociedade, passando da memória individual à coletiva para, em seguida, organizar as informações de modo a traduzi-las em termos semióticos a fim de se caracterizar uma determinada identidade cultural por meio de sua materialidade. Para tanto, foram utilizados diferentes instrumentos de pesquisa: na fase inicial, pesquisas documentais e iconográficas contextualizaram o universo estudado. Após uma seleção dos respondentes através de questionários, utilizou-se o método da história oral, por meio de entrevistas temáticas ${ }^{7}$ para obtenção de informações sobre experiências vividas e memórias dos entrevistados, tendo em vista a materialidade presente nas lembranças. A partir daí, iniciou-se a pesquisa de campo, na qual foram novamente realizadas entrevistas temáticas não estruturadas, observação direta, anotações e registros fotográficos, além de gravações em áudio.

\subsection{Contextualização do universo material}

A fim de caracterizar a materialidade do ambiente doméstico dos sítios, fazendas e bairros rurais de São Paulo das últimas décadas do século XIX e primeiras décadas do século XX, foram realizadas diferentes abordagens metodológicas de pesquisa: primeiramente, foi realizada uma pesquisa documental em obras de reconhecido teor regionalista, romances e livros de contos de autores consagrados; em seguida, foi feito um levantamento iconográfico por meio da análise de obras de arte e fotografias da época; em paralelo, foram realizadas visitas a museus e exposições de objetos do período.

\section{Pesquisa documental}

Com o olhar na cultura paulista rural do começo do século XX, foi feito um levantamento de termos e artefatos típicos do ambiente doméstico presente nos glossários das seguintes obras literárias: Musa Caipira e As Estrambóticas Aventuras do Joaquim Bentinho, de Cornélio Pires (1985); Os caboclos, Mixuangos e Leréias: histórias contadas por eles mesmos, de Valdomiro Silveira ${ }^{8}$ (1975) e O Dialeto Caipira, de Amadeu Amaral (1955). Este levantamento resultou em uma lista com 59 artefatos que, além de caracterizarem o universo material caipira, serviram como referência em termos materiais e culturais para as análises dos objetos encontrados nas residências visitadas na pesquisa de campo.

\footnotetext{
7 Entrevistas temáticas "são entrevistas que se referem a experiências ou processos específicos vividos ou testemunhados pelos entrevistados" (NEVES, 2003, p. 33).

8 Valdomiro Silveira (1873-1941) é considerado um precursor da literatura regionalista, de acurado rigor no registro da fauna, da flora e do homem interiorano de São Paulo entre o final do século XIX e o princípio do século XX. Sua obra é composta por: Os caboclos (1920); Nas serras e nas furnas (1931); Mixuangos (1937); Leréias (1945); Mucufos (livro inédito, reúne 24 contos escritos entre 1894 e 1938, publicados em jornais paulistas).
} 
Algumas interpretações puderam ser feitas sobre estes artefatos: notou-se uma forte herança indígena no universo caipira, principalmente em relação ao uso da cerâmica, de objetos feitos a partir de cascas de plantas cucurbitáceas, como a cabaça e o cuietê, e das cestarias com trama de taquara ou cipó. Também foi possível perceber uma predominância de utensílios ligados ao trato com os animais ou ao preparo de alimentos.

A fé religiosa se mistura às crenças pagãs e às superstições e atribui ao sobrenatural poderes de proteção. É o caso do patuá, bentinho ou arrelique9:

Patuá: pequeno invólucro [de pano] contendo orações, relíquias e pedras sagradas que os caipiras caboclos e pretos trazem ao pescoço [pendurado em um cordão]

Bentinho: papel contendo uma oração escrita, e que se dobra muitas vezes, encapando-o em pano, e assim se traz pendurado ao pescoço por um fio, depois de o fazer benzer por um padre; medalha com imagem benzida pelo padre romano

Arrelique: breve, patuá, saquinho de pano que se põe ao pescoço, com algum remédio

Ainda com relação à caracterização deste universo material, foi realizada uma pesquisa no acervo de utensílios encontrado no Fichário Ernani Silva Bruno dos Equipamentos, Usos e Costumes da Casa Brasileira (ACAYABA, 2000), que reúne 28 mil registros recolhidos a partir de relatos de cronistas e viajantes, inventários e testamentos, além de literatura ficcional, em quatro séculos de história. Este material encontrase disponível para consulta no site do Museu da Casa Brasileira (EQUIPAMENTOS, s/d.).

\section{Pesquisa iconográfica}

Como subsídio para a caracterização do universo material da época citada, foram realizadas pesquisas iconográficas, por meio da análise de obras de arte e de fotografias da época, além de visitas a museus e a exposições de objetos do período.

Para auxiliar a caracterização do universo caipira no final do século XIX, foram analisadas seis obras do pintor Almeida Júnior ${ }^{10}$ que pertencem ao acervo da Pinacoteca do Estado de São Paulo: O violeiro (1899); Amolação interrompida (1894); Apertando o lombilho (1895); Estudo para cabeça de caipira (1893); Caipira picando fumo (1893) e Cozinha caipira (1895) (Quadro 1). Observou-se que estas representações confirmam aspectos descritos por Brandão (1983) em relação à vida simples do caipira, sua herança indígena, a viola nas horas de lazer e suas habitações precárias com poucos móveis, decorrentes de um tipo de vida nômade devida à falta de propriedade da terra e ao hábito das queimadas para o preparo do terreno antes do plantio, danificando o solo a ponto de expulsá-los após algumas colheitas. A precariedade de suas moradias sem conservação, exibindo a estrutura de pau a pique sem o barreado, também apontam para um caráter provisório de habitação.

\footnotetext{
9 Os termos foram extraídos dos glossários encontrados em AMARAL (1955); SILVEIRA (1975a, b e c); e PIRES (1985).

10 O desenhista e pintor José Ferraz de Almeida Júnior (1850 - 1899) ficou conhecido por sua temática caipira e sua pintura de gênero. De caráter realista, suas telas retratam o caipira em seu ambiente pobre e simples, em sua vida calma e triste, sem nunca ridicularizá-lo ou transformá-lo em personagem pitoresco (ALMEIDA Júnior, s/d.).
} 

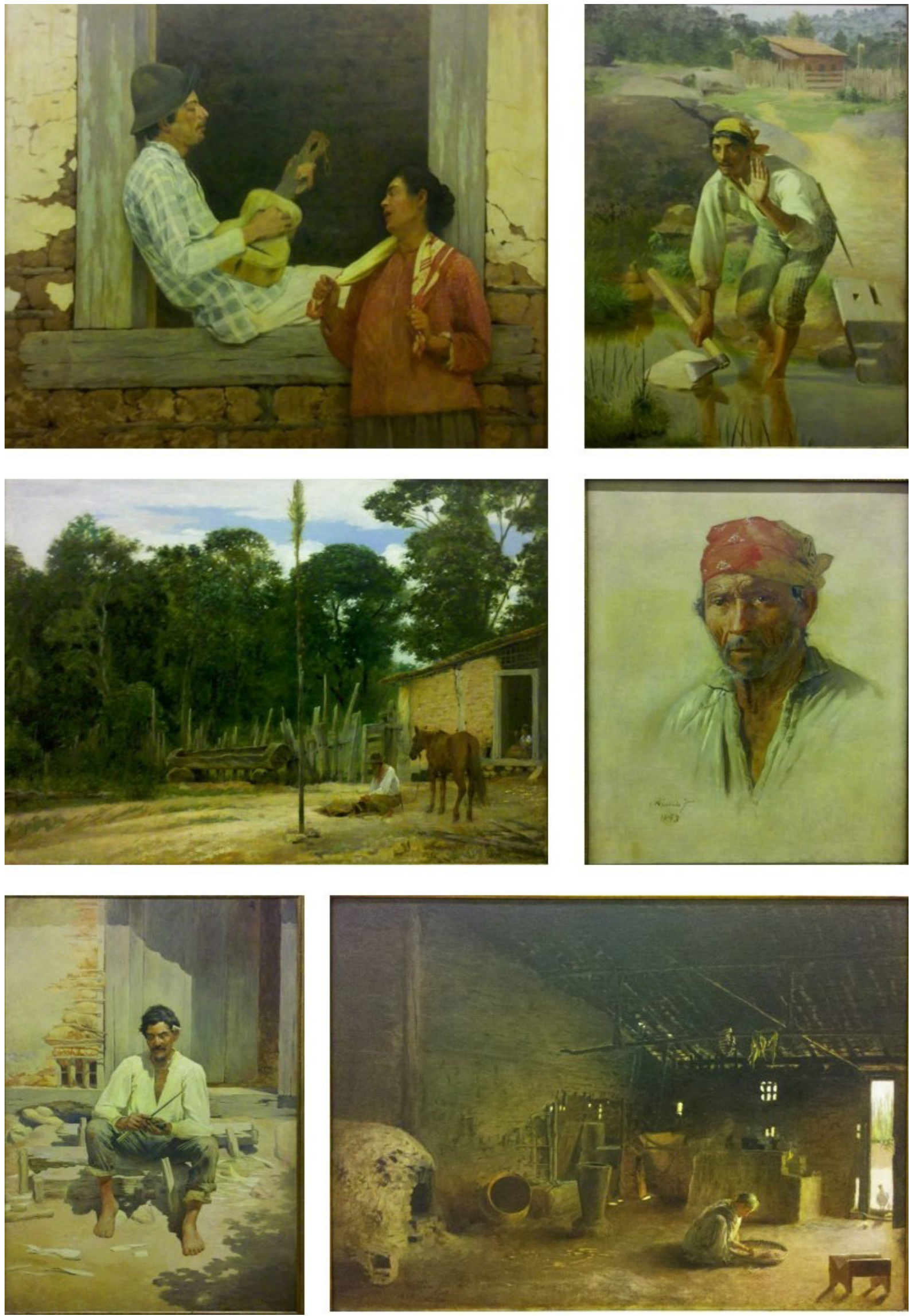

Quadro 1. Representações do universo caipira nas telas do pintor Almeida Júnior. Acervo da Pinacoteca do Estado de São Paulo. Registro fotográfico da autora, 2013.

Da esquerda para a direita e de cima para baixo: O violeiro (1899), Amolação interrompida (1894), Apertando o lombilho (1895), Estudo para cabeça de caipira (1893), Caipira picando fumo (1893), Cozinha caipira (1895). 


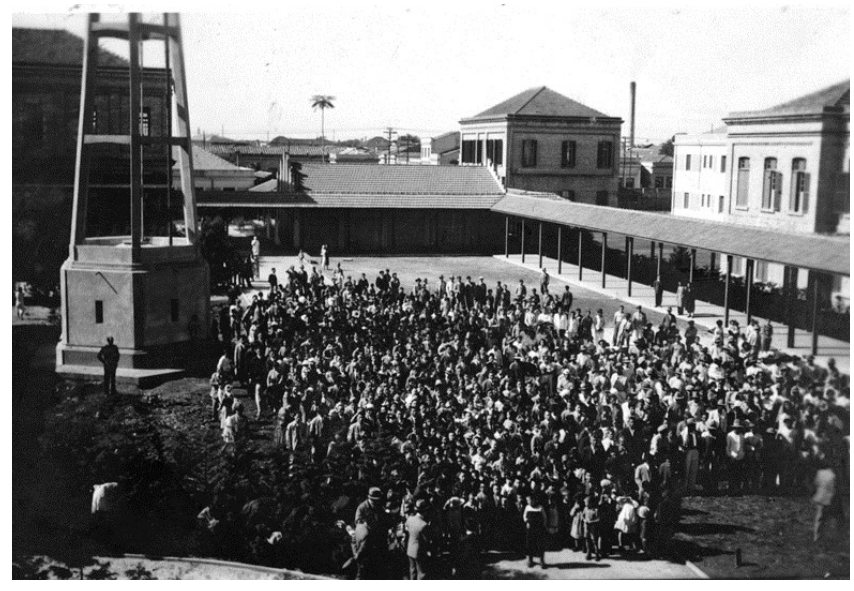

Figura 12. Imigrantes aguardando exame médico no pátio da Hospedaria, década de 1930 (MUSEU DA IMIGRAÇÃO DO ESTADO DE SÃO PAULO, s/d.)

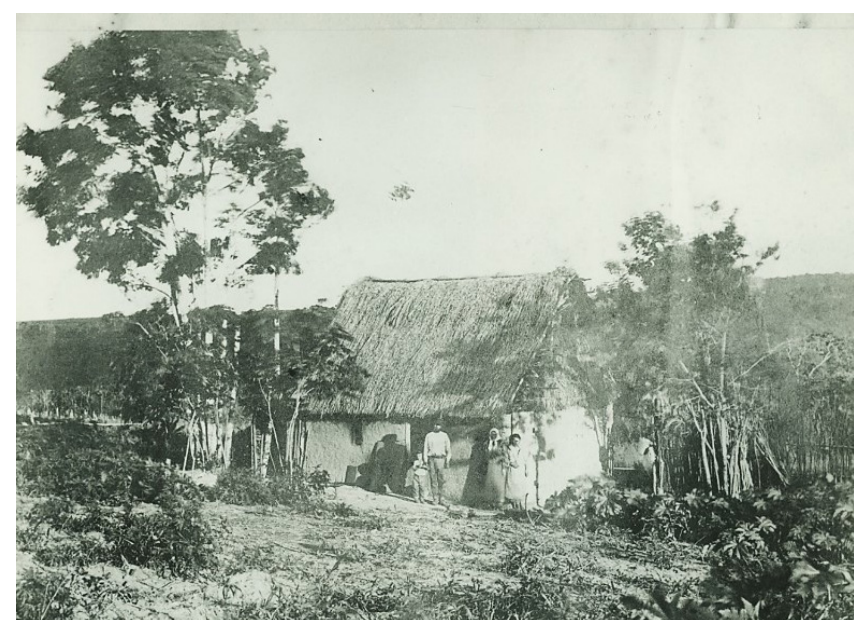

Figura 13. Alojamento e família de imigrante russo, Nova Odessa, 1906 (MUSEU DA IMIGRAÇÃO DO ESTADO DE SÃO PAULO, s/d.).
Para caracterizar o universo dos imigrantes, que vieram ao país para trabalhar nas fazendas paulistas como colonos, a pesquisa iconográfica se concentrou nos acervos virtuais do Museu da Imigração do Estado de São Paulo (MUSEU DA IMIGRAÇÃO DO ESTADO DE SÃO PAULO, s/d.), antiga Hospedaria dos Imigrantes.

A partir dele, foi possível notar a situação de pobreza das famílias, tanto ao chegar ao Brasil - ainda nas dependências da hospedaria, em São Paulo (Figura 12), aguardando pelo exame médico antes de seguir viagem para o seu destino ainda desconhecido - quanto em suas moradias nas fazendas - como retratado na fotografia da casa coberta de palha do núcleo colonial de Nova Odessa em 1906 (Figura 13). A festa da colheita do café na Fazenda Quilombo, município de Limeira, ilustra ainda a imensa quantidade de trabalhadores imigrantes empregados na cultura cafeeira de uma das maiores plantations da época (Figura 14).

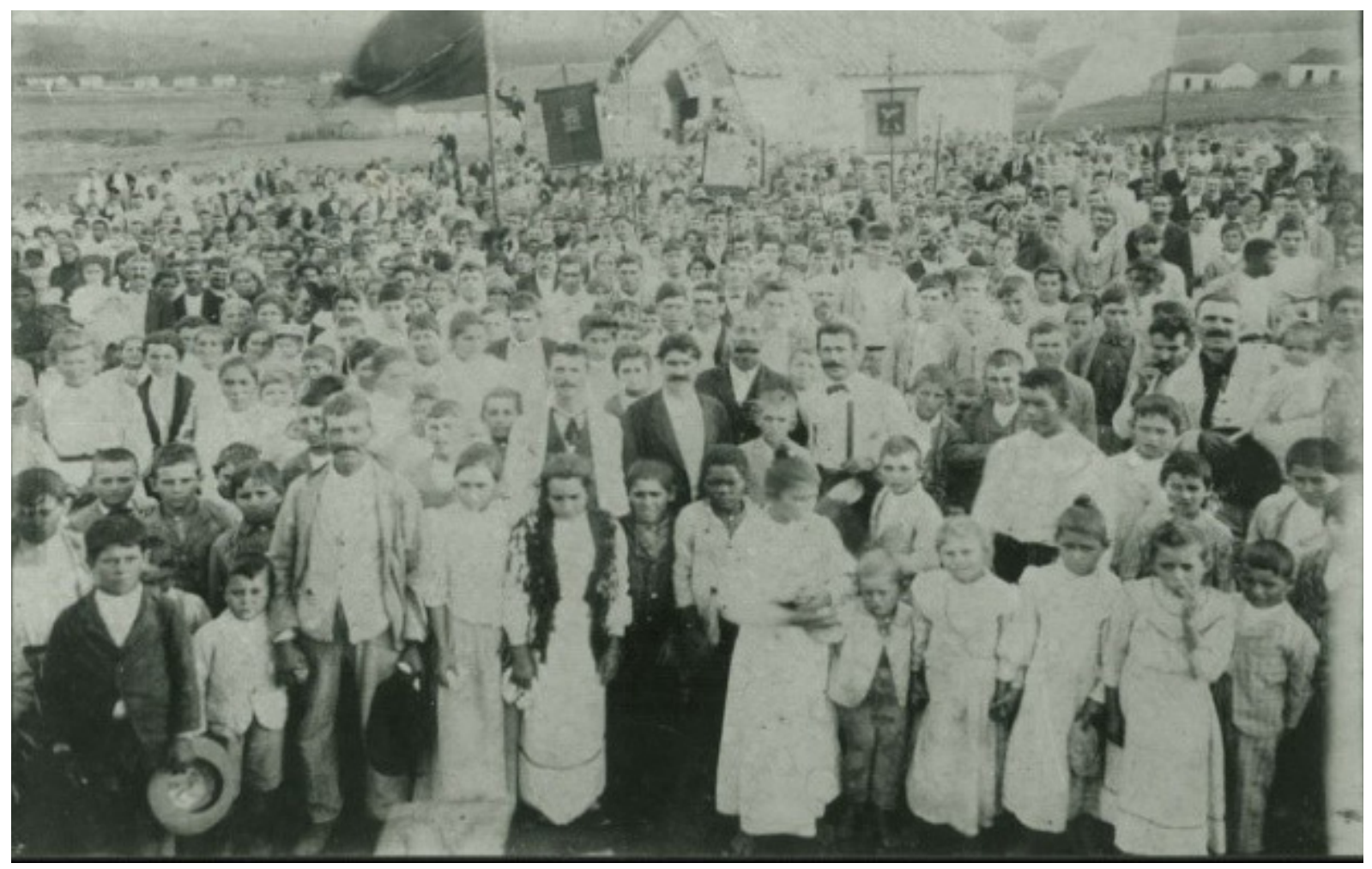

Figura 14. Festa da colheita na Fazenda Quilombo, Limeira, 1909 (MUSEU DA IMIGRAÇÃO DO ESTADO DE SÃO PAULO, s/d.) 


\section{Visitas a museus e exposições}

Por se tratar de um estudo sobre artefatos, identificou-se a necessidade do contato físico da pesquisadora com aqueles típicos do universo estudado para a percepção de seus aspectos sintáticos e materiais. Desta forma, foram realizadas algumas visitas a museus e exposições pertinentes como relatado a seguir. Por se tratar de uma pesquisa de abordagem semiótica e não histórica, o critério de seleção dos locais visitados se baseou na sua representatividade sob a ótica da tradição.

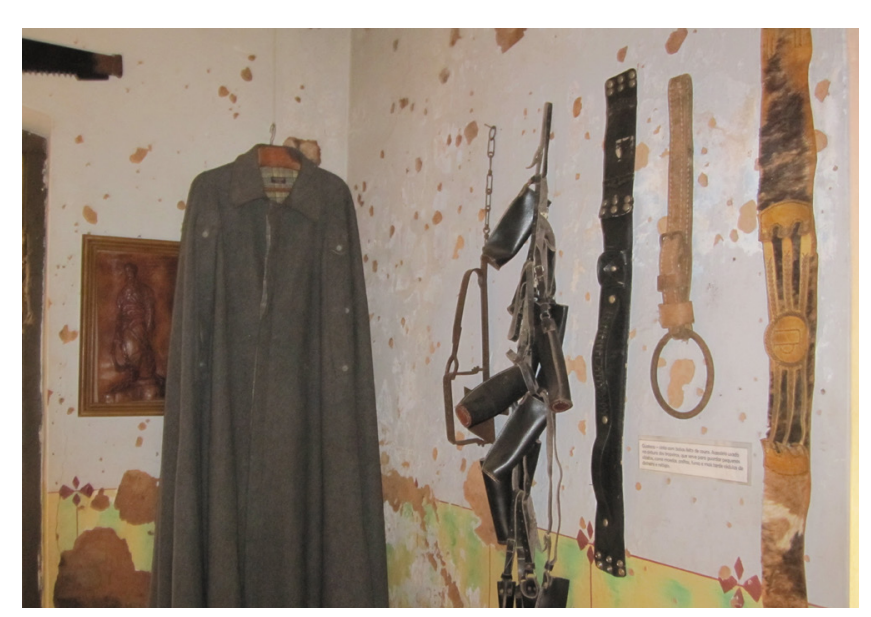

Figura 15. Indumentária dos tropeiros. Acervo do Museu de História e Folclore Maria Olímpia. Registro fotográfico da autora, 2013.

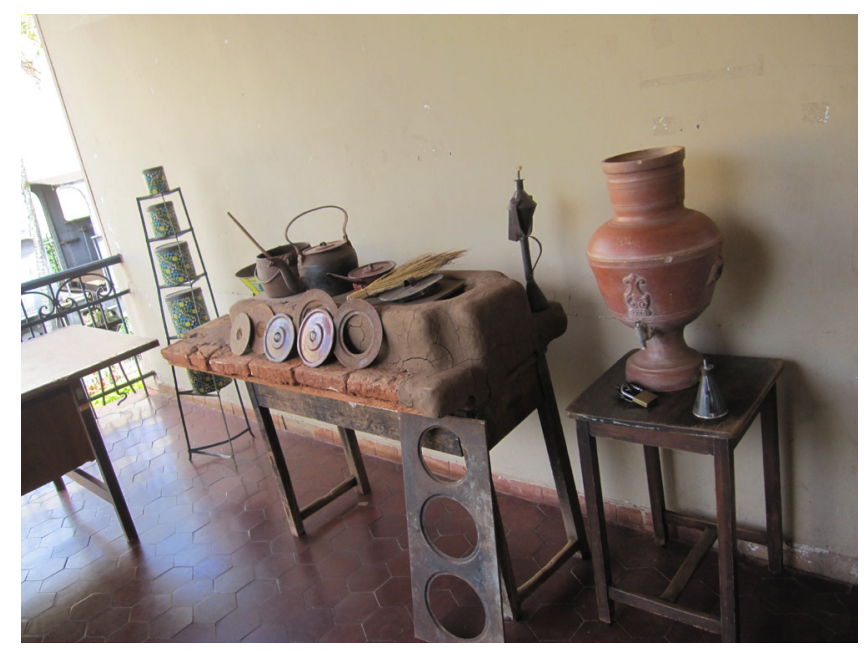

Figura 16. Forno a lenha e utensílios domésticos. Acervo do Museu de História e Folclore Maria Olímpia. Registro fotográfico da autora, 2013.
A primeira visita se deu ao Museu de História e Folclore Maria Olímpia, visitado em dezembro de 2013. Localizado na cidade de Olímpia, São Paulo, o museu é considerado um dos mais completos do gênero no Brasil.

Seu acervo possui cerca de 10 mil peças, entre indumentárias diversas de danças, folias e ritos (como a Folia de Reis e as Congadas, entre outros); instrumentos musicais; peças de hábitos tradicionais; indumentárias (Figura 15); esporas; luminárias; serras; ferros de passar; equipamentos rudimentares agrícolas; utensílios domésticos (Figura 16) compostos por peças de barro, bambu, madeira, couro, ágata; toalhas com abrolhos; trançados em palha; crochê; pinturas e demais objetos representativos dos mitos brasileiros, além de uma biblioteca especializada nas tradições da cultura popular.

Tendo completado quarenta anos de existência, está localizado no palacete Giosué Tonanni, concluído em 1916, cartão postal da cidade, e exibe em suas dependências externas uma locomotiva inglesa de 1892 tipo

Maria Fumaça, que trafegara pelos trilhos da Mogiana nos tempos áureos do café. Foi possível observar a predominância de certos aspectos formais nos objetos relacionados ao universo rural paulista: rudimentares em sua maioria, apresentam soluções simples, materiais aparentes como cerâmica, ferro, couro, palha, cestaria e ágata, com poucos detalhes decorativos, prezando pela funcionalidade. O acervo relativo a São Paulo está inserido na sala dedicada à região sudeste, portanto, não podemos considerá-lo sem ressalvas. Mas, considerando-se que a cultura caipira se relaciona com uma área que vai do norte do Paraná ao sul de Minas Gerais, foi possível deste modo, considerar os objetos como símbolos da cultura caipira embora não especificamente paulistas.

Na mesma época, realizamos a visita ao Museu Casa do Caipira, uma casa de colono localizada dentro 
da Fazenda Chocolate, em Itu, recuperada e remobiliada há cerca de quinze anos com a finalidade de se transformar em atrativo turístico e educativo pelos seus proprietários. Apesar de não ser um museu reconhecido pelo Instituto Brasileiro de Museus (Ibram), a visita à Casa do Caipira, serviu-nos para ilustrar como a sua cultura é retratada sem o rigor acadêmico e o que se pôde ver é muito fiel, em termos materiais, ao pesquisado na literatura e no Museu de História e Folclore Maria Olímpia.

Com o auxílio de livros sobre a cultura caipira e relatos dos antigos moradores, os donos da fazenda reconstituíram uma antiga construção da colônia com objetos e móveis de época de uso cotidiano dos caipiras e dos antigos imigrantes italianos que substituíram a mão de obra escrava da fazenda cafeeira no fim do século XIX, garimpados em fazendas vizinhas, baseados em histórias locais e nos livros de Cornélio Pires (Figura 17).

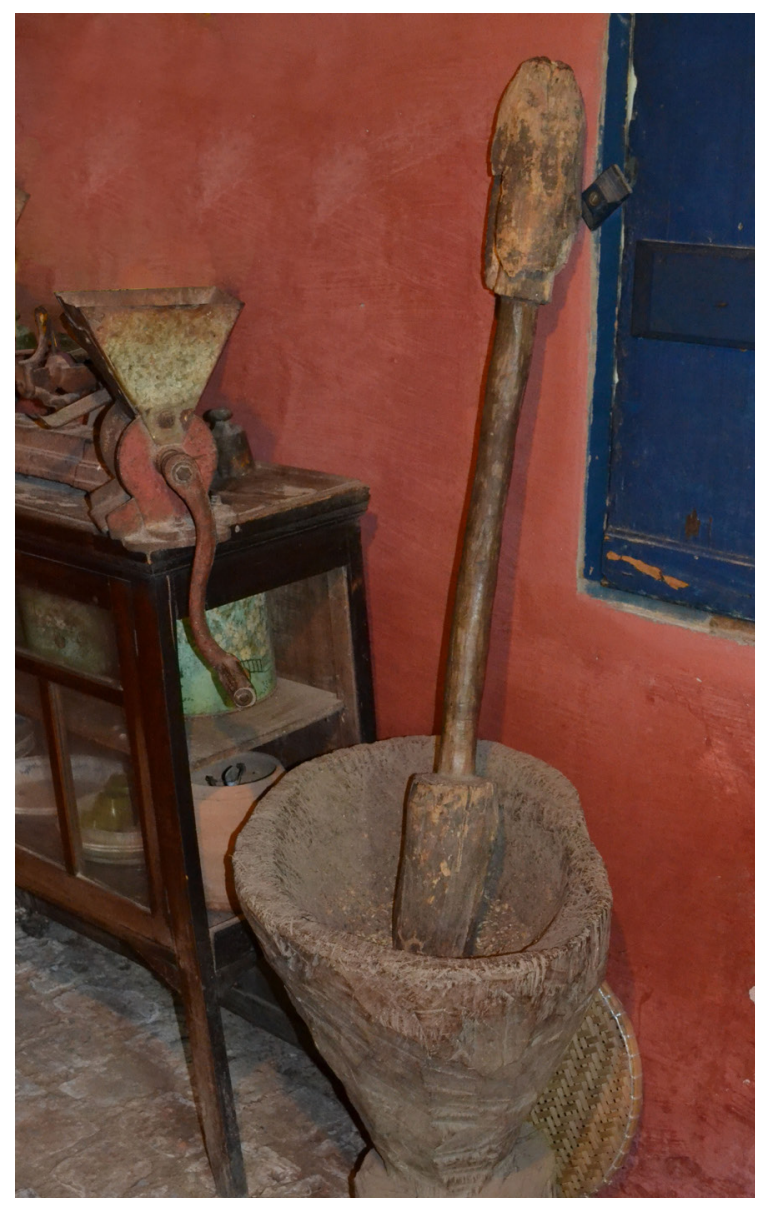

Figura 17. Interior da Casa do Caipira. Fazenda Chocolate, Itu. Registro fotográfico da autora, 2014.

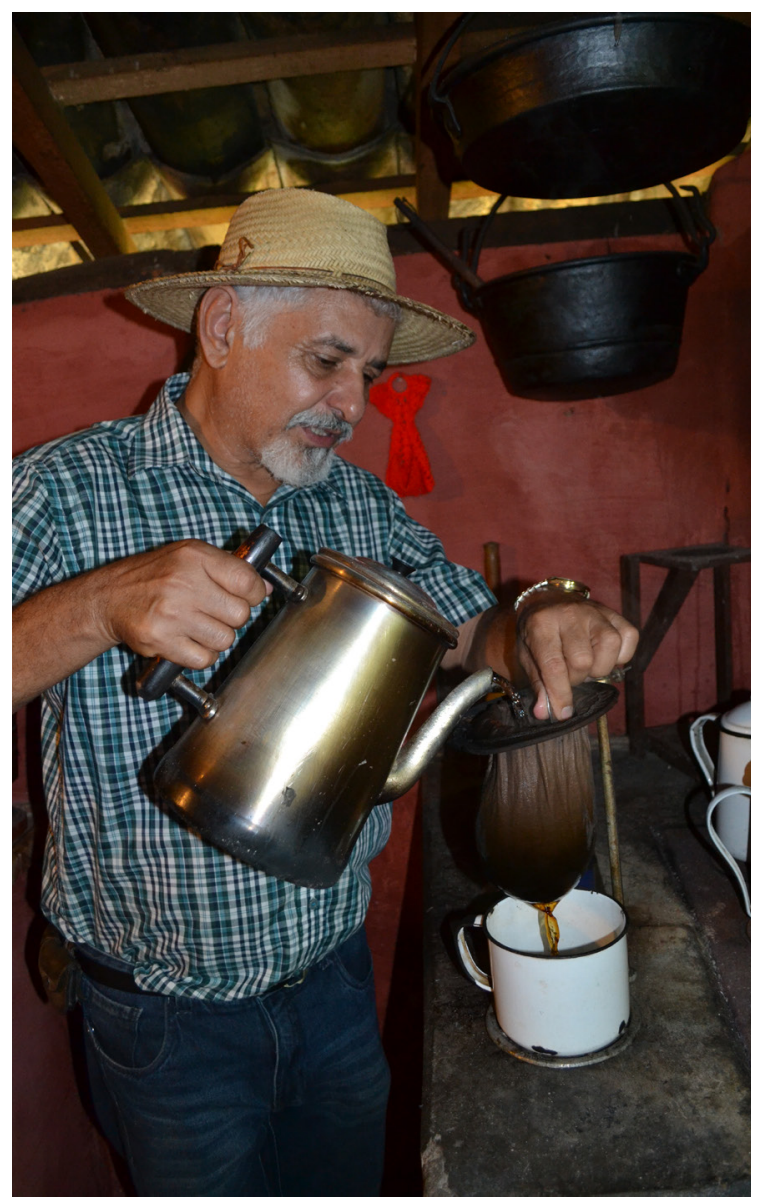

Figura 18. Compadre Timóteo passando café. Fazenda Chocolate, Itu. Registro fotográfico da autora, 2014.

A visita guiada é feita por "compadre Timóteo" (Figura 18), um artista de teatro amador que trabalhou no Museu Mazzaropi, em Taubaté, de onde extrai as falas e trejeitos típicos do caipira para encanto dos turistas. Ainda foi possível visitar a casa-grande, a senzala e uma pequena capela do ano de 1925 recémrestaurada.

Em contraponto às visitas anteriores, cujos acervos possuem caráter respectivamente folclórico e turístico, realizamos uma visita ao Solar da Marquesa de Santos, em São Paulo, onde foi possível conhecer parte da Coleção de Bens Móveis Históricos, com cerca de oitocentos objetos de madeira, couro, barro, porcelana e metal que compõem o mobiliário de imóveis rurais de taipa remanescentes dos séculos XVII ao XIX. 
Os objetos foram reunidos por ocasião da comemoração do IV Centenário da cidade de São Paulo, em 1954, vindos de regiões do interior do estado e de Minas Gerais, principalmente do Vale do Paraíba, incorporados por meio de aquisição, doação ou custódia. São centenas de peças de mobiliário, utensílios de cozinha, ferramentas, adornos domésticos, imagens religiosas e outros objetos que teriam ocupado imóveis rurais dos séculos XVII, XVIII e XIX de famílias paulistas, as quais não poderiam ser chamadas de caipiras devido à sua condição social.

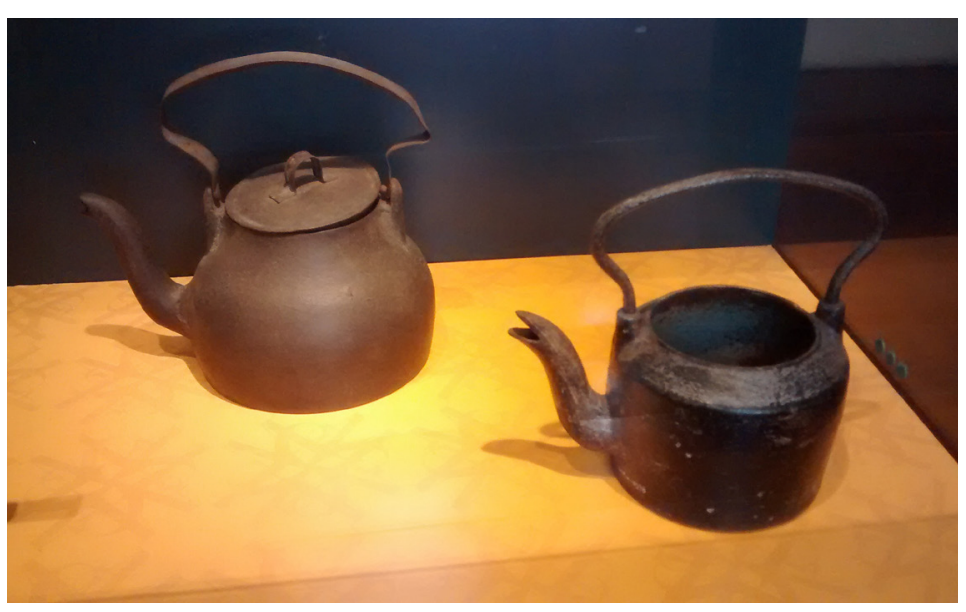

Figura 19. Simplicidade nos objetos de serviço. Coleção de Bens Móveis Históricos do Solar da Marquesa de Santos, São Paulo. Registro fotográfico da autora, 2014.
Pode-se notar duas classes distintas de objetos: na cozinha ou nas áreas de serviço da casa, a predominância pela funcionalidade nos objetos rústicos e simples, como o tacho de cobre e o filtro de pedra (Figura 19). Por outro lado, as louças e pratarias expostas são ricamente decoradas, confirmando a condição socioeconômica daquelas famílias em diferentes épocas contempladas (Figura 20).

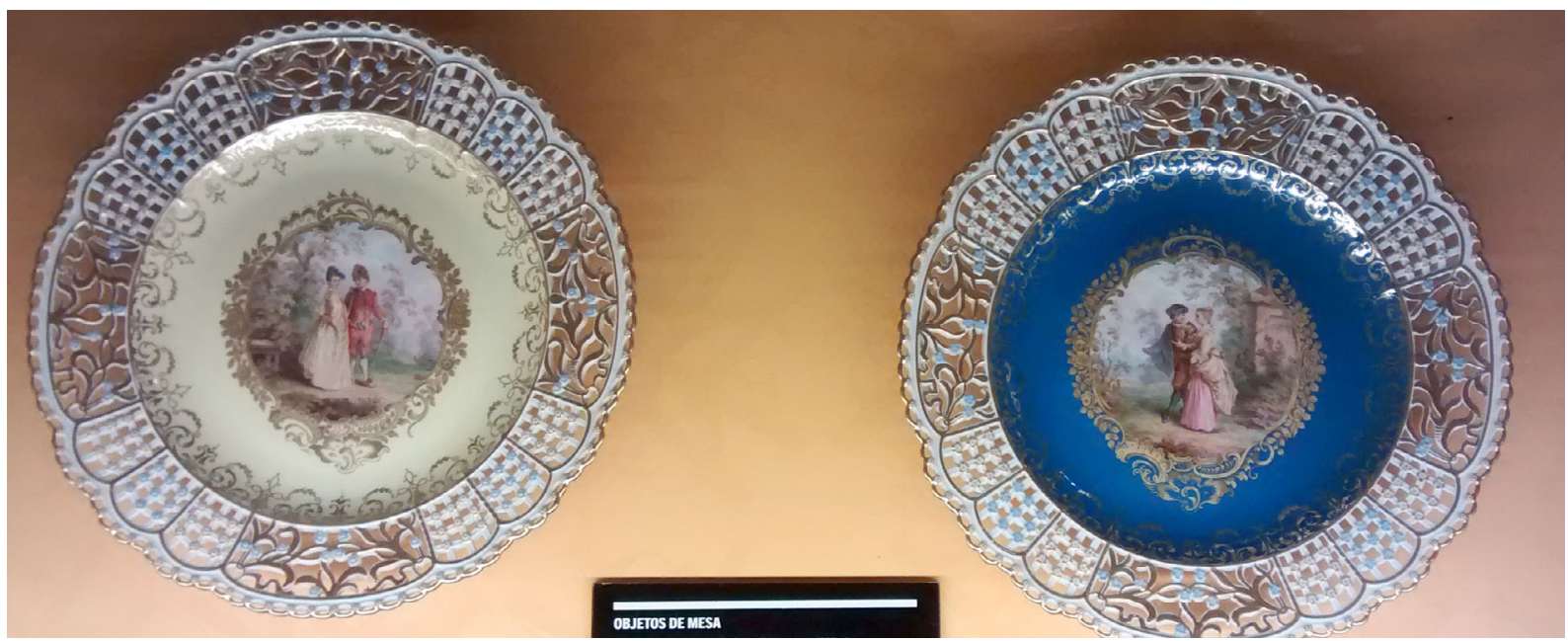

Figura 20. Objetos ricamente decorados, símbolo de status. Coleção de Bens Móveis Históricos do Solar da Marquesa de Santos, São Paulo. Registro fotográfico da autora, 2014.

A próxima visita efetuada teve como foco o universo dos imigrantes, neste caso específico, uma comunidade de tradição tirolesa no estado de São Paulo, preservada por descendentes de imigrantes da região do Trento, na Itália. Visitamos o Centro Histórico-Cultural de Santa Olímpia, localizado na cidade de Piracicaba, no bairro rural de mesmo nome que surgiu a partir da Fazenda Santa Olímpia, de propriedade de quatro famílias da região do Tirol que emigraram para trabalhar na lavoura de café da Fazenda Sete Quedas na região de Campinas. Terminado seus contratos, mudaram-se para a região de Piracicaba e, posteriormente, adquiriram as terras em Santa Olímpia, dando origem, em 1892, àquele que seria posteriormente o bairro de mesmo nome.

Conhecida na região como "um pequeno pedaço do Trentino no Brasil", província italiana da região do Tirol que até a Primeira Guerra Mundial fazia parte do império Austro-húngaro, Santa Olímpia mantém viva a 


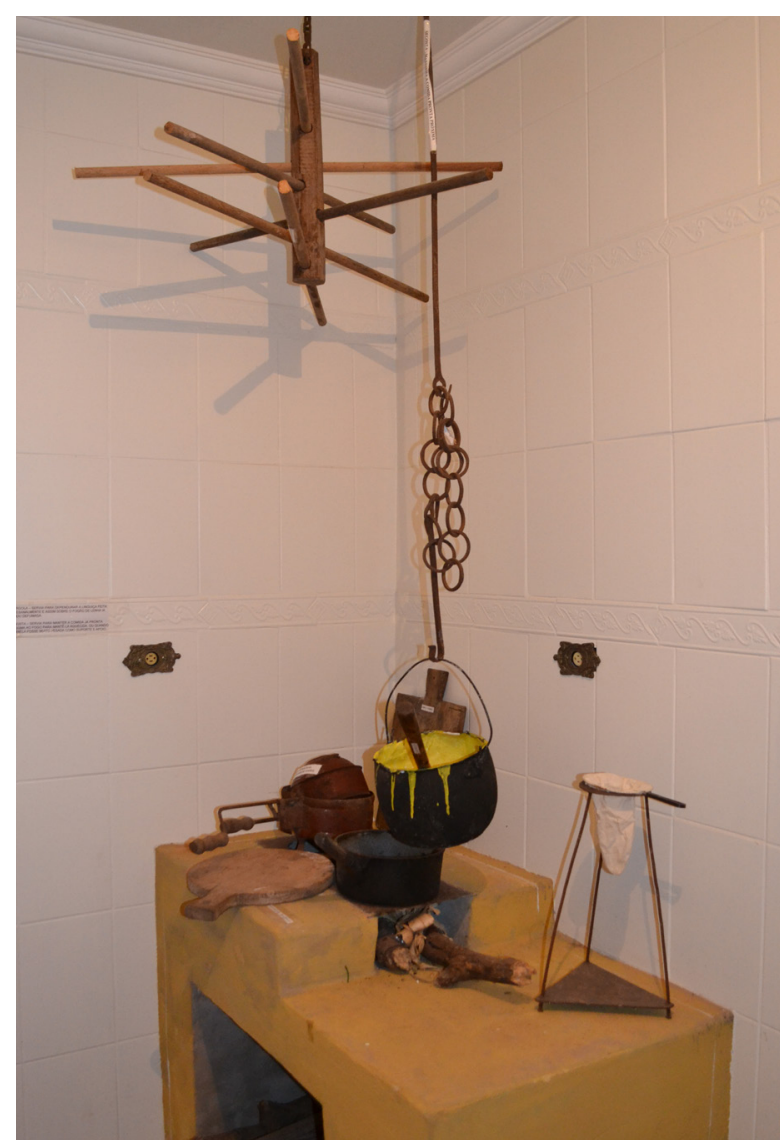

Figura 21. "Spergola". Acervo do Centro Histórico-Cultural de Santa Olímpia, Piracicaba. Registro fotográfico da autora, 2014.

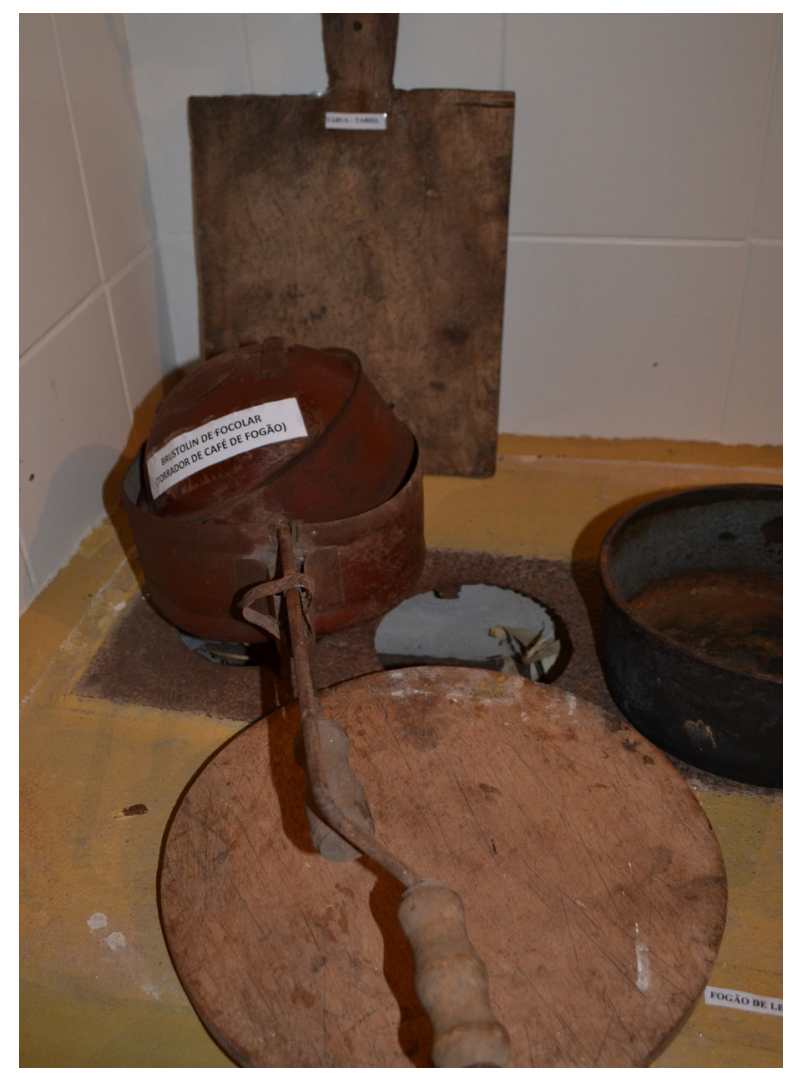

Figura 22. "Brustolin de focolare". Acervo do Centro Histórico-Cultural de Santa Olímpia, Piracicaba. Registro fotográfico da autora, 2014. memória e as tradições dos pioneiros através do folclore, da gastronomia, das festas típicas e do modo de viver e falar de seus moradores.

Junto à sede da Associação de Moradores, situada na mais antiga casa colonial do bairro, datada do início do século XX, funciona o Centro Histórico-Cultural, um pequeno museu com objetos pertencentes aos pioneiros do bairro, onde é possível perceber o modo de vida dos primeiros colonos trentinos.

A visita ao bairro em julho de 2014 se deu em função da pesquisa de campo, para entrevistar e fotografar a residência de um morador, membro de uma das famílias fundadoras. Na ocasião, pudemos conhecer o Centro Cultural e verificar que muitos dos objetos e hábitos relacionados aos artefatos encontrados atualmente nas residências visitadas, também faziam parte da cultura italiana daquela região. É o caso da spergola, um tipo de cabide feito de madeira que servia para pendurar a linguiça sobre o fogão a lenha para defumar (Figura 21) ou o torrador de café para fogão a lenha, chamado de brustolin de focolare (Figura 22).

A última visita feita pela pesquisadora foi à exposição "Modos de morar dos paulistas: 18401940", em outubro de 2014, no Espaço Cultural Engep, em Limeira. A exposição teve curadoria de historiadores da Universidade Estadual de Campinas (Unicamp) e apoio da Pinacoteca do Estado. Nela, foi possível observar o modo de morar dos paulistas e as transformações significativas nas vivências e no cotidiano doméstico de famílias do interior do estado, em um período de cem anos compreendido entre 1840 e 1940.

Notou-se, através dos objetos e da disposição dos espaços da habitação, uma fusão de tradições rurais e costumes coloniais com os novos ares que se espalhavam pelo Brasil do século XIX devido à presença da Corte no Rio de Janeiro 
a partir de 1808 e, posteriormente, com as influências europeias sobre a aristocracia do café.

Distribuída pelo antigo casarão construído na década de 1850 pelo então proprietário da Fazenda Quilombo e, posteriormente, senador do estado de São Paulo após a proclamação da República, que hoje abriga o Espaço Cultural Engep, a mostra dividia-se em três ambientes: a primeira sala foi dedicada à arquitetura e a detalhes de construção, técnicas e materiais da época; na sala principal, pudemos vislumbrar o interior das casas, ambientes típicos de quarto e salas de estar, cristaleiras exibindo ricas porcelanas francesas e alemãs (Figura 23), móveis de palhinha, retratos dos antepassados em molduras ovais pendurados na parede (Figura 24); um terceiro espaço era dedicado à religiosidade presente nos ambientes domésticos, predominantemente católica, com imagens de santos, oratórios e crucifixos (Figura 25), além de vitrines com apetrechos de serviço, equipamentos domésticos e demais utensílios de cozinha (Figura 26).

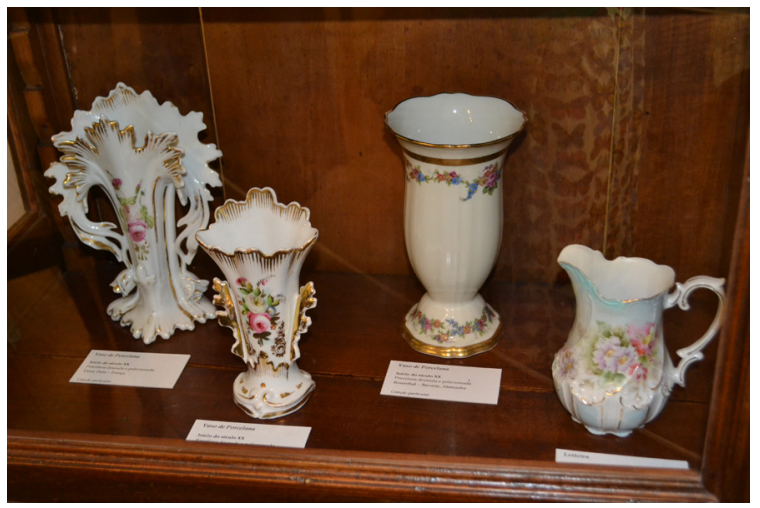

Figura 23. Porcelanas vindas da Europa. Exposição "Modos de morar dos paulistas: 1840-1940", Espaço Cultural Engep, Limeira. Registro fotográfico da autora, 2014.

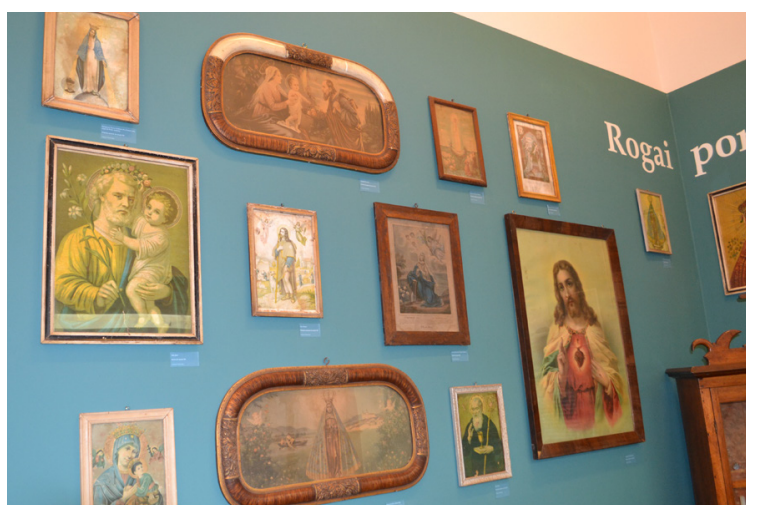

Figura 25. Religiosidade no ambiente doméstico. Exposição "Modos de morar dos paulistas: 1840-1940", Espaço Cultural Engep, Limeira. Registro fotográfico da autora, 2014.

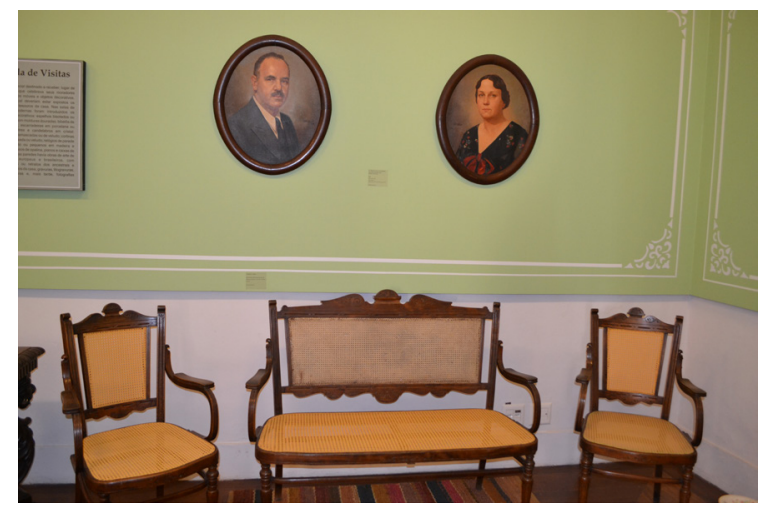

Figura 24. Retratos de parede e móveis de palinha. Exposição "Modos de morar dos paulistas: 1840-1940", Espaço Cultural Engep, Limeira. Registro fotográfico da autora, 2014.

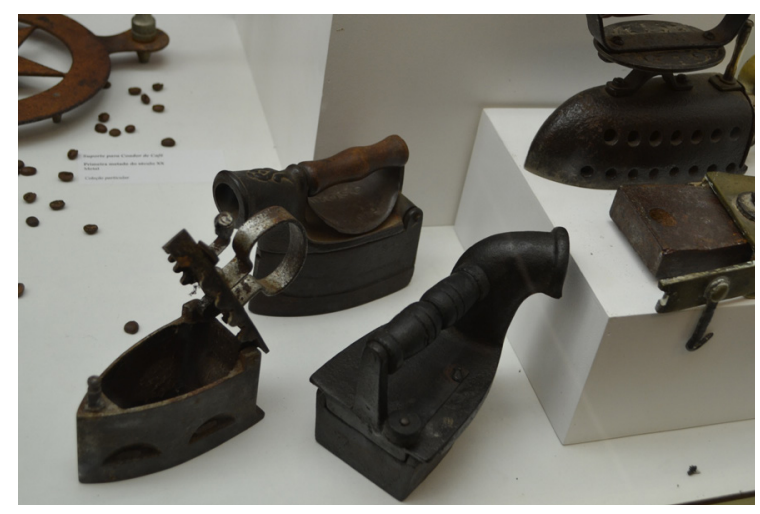

Figura 26. Apetrechos domésticos de serviço. Exposição "Modos de morar dos paulistas: 1840-1940", Espaço Cultural Engep, Limeira. Registro fotográfico da autora, 2014.

É importante salientar que a exposição retratava o ambiente das residências de grandes cafeicultores paulistas, abastados fazendeiros portugueses ou seus descendentes, proprietários de grandes extensões de terras. Mesmo não sendo a classe social na qual se insere este estudo, ligado aos pequenos produtores caipiras e colonos, foi interessante notar alguns hábitos comuns como, por exemplo, a questão da religiosidade doméstica e da presença dos antepassados por meio de seus retratos nos principais ambientes da casa, além de algumas referências de status como exibir a porcelana decorada em cristaleiras. 


\subsection{Identificação, localização, análise e confronto dos artefatos}

Os objetos desse estudo são uma resultante do cruzamento de algumas variantes: primeiramente, podemos citar como característica tratarem-se de artefatos populares, uma vez que representam a cultura popular, entendendo o popular como "uma lógica de práticas dispersas, temporal e localmente determinadas" (CHAUÍ, 1986, p. 90). Podemos olhar para estes artefatos ainda por serem representativos das camadas economicamente menos favorecidas da população, o que, contextualizando-os em relação à história da formação da sociedade paulista e seu passado rural, significa falarmos a respeito de famílias de brasileiros, descendentes de portugueses sem posses, ou colonos imigrantes que vieram a São Paulo para trabalhar nas grandes lavouras monocultoras, especialmente de café, ou ainda descendentes de escravos libertos ou indígenas que habitavam o estado de São Paulo nos tempos da colônia.

Segundo, são artefatos memoráveis, ou seja, que participam da memória afetiva de uma determinada parcela da população adulta, paulista, nos dias atuais, cujas famílias se enquadram na definição acima.

Terceiro, são artefatos ordinários, que participam da vida privada e do cotidiano de famílias com as características acima citadas, que se pode notar nos dias atuais, em visita às suas residências durante a pesquisa de campo, ao que se dará o nome de artefatos notáveis.

Para fins metodológicos, foram adotados os termos artefatos memoráveis e artefatos notáveis para diferenciação dos objetos em função das fases da pesquisa. Por artefatos memoráveis, compreendemse os objetos que participam das memórias afetivas dos adultos relatadas em entrevistas temáticas e depoimentos espontâneos. Por artefatos notáveis, entendem-se os artefatos memoráveis que podem ser notados, isto é, localizados, nas residências de pessoas idosas em cidades de tradição rural ou em zonas rurais no interior paulista, na fase da pesquisa de campo.

\section{O método da história oral em pesquisas sobre memória e identidade}

O método da história oral foi utilizado por se caracterizar pela utilização da memória como fonte principal, a qual provê material em forma de narrativa, a fim de dar origem à produção de um documento (NEVES, 2003).

\footnotetext{
A história oral é uma metodologia de pesquisa que consiste em realizar entrevistas gravadas com pessoas que podem testemunhar sobre acontecimentos, conjunturas, instituições, modos de vida ou outros aspectos da história contemporânea. [...] As entrevistas de história oral são tomadas como fontes para a compreensão do passado, ao lado de documentos escritos, imagens e outros tipos de registro. Caracterizam-se por serem produzidas a partir de um estímulo, pois o pesquisador procura o entrevistado e lhe faz perguntas, geralmente depois de consumado o fato ou a conjuntura que se quer investigar (CENTRO DE PESQUISA E DOCUMENTAÇÃO..., s/d.)
}

Outra característica do método é relativa à temporalidade. O documento produzido irá conter o tempo passado, percorrido pela trajetória de vida dos entrevistados, bem como o tempo presente, que orienta e estimula tanto o entrevistador quanto as respostas do entrevistado (NEVES, 2003).

Para identificar os artefatos domésticos memoráveis recorrentes, foram utilizados dois instrumentos de pesquisa, os depoimentos informais e as entrevistas temáticas. A partir da definição dos parâmetros que 
caracterizaram o objeto do estudo, o primeiro passo para a coleta de dados foi falar com o maior número possível de pessoas adultas de diferentes classes sociais, idades e profissões, desde que fossem paulistas, pedindo sugestões de objetos que, em sua opinião fossem característicos deste contexto da pesquisa, ou seja, populares domésticos vinculados ao ambiente rural das cidades do interior.

Foram coletadas dezenas de depoimentos informais de pessoas que se identificaram com o contexto da pesquisa e que, ao tomarem consciência do tema, passaram a relatar suas memórias de infância em casas de familiares e sugerir objetos que, em sua opinião, deveriam fazer parte da pesquisa por serem considerados "típicos". Estas sugestões foram registradas por um período de cerca de seis meses e deram origem a uma lista com 58 itens do que se chamou de artefatos típicos sugeridos (Tabela 1).

\begin{tabular}{|c|c|}
\hline \multicolumn{2}{|c|}{ Depoimentos informais - Lista de artefatos típicos sugeridos } \\
\hline Anão de jardim & Panela de barro \\
\hline Bacia de alumínio & Panela de ferro \\
\hline Bomboniere bico de jaca com guloseima & Paneleiro de chão \\
\hline Caixinha de costura/aviamento & Paneleiro de parede \\
\hline Calendário - folhinha & Paneleiro de teto \\
\hline Caneca de ágata & Pano de prato pintado à mão com barra de crochê \\
\hline Caneca de porcelana de brinde de festa & Pato de porcelana \\
\hline Canivete com cabo de madre-perola & Pé de Romã \\
\hline Capa de botijão de gás & Peneira de taquara \\
\hline Carrinho de feira & Porta papel higiênico pendurado no banheiro \\
\hline Canteiro com ervas e tempeiros no jardim & Prendedor de roupa de madeira \\
\hline Coador de café de pano & puxa-saco \\
\hline Copo americano pra tomar café & Relicário/Oratório de santo \\
\hline Cortina de renda & Retrato de família com moldura oval na parede \\
\hline Colher de pau & Rolo de macarrão \\
\hline Espelho de banheiro com moldura abóbora & Roseira \\
\hline Ferro à carvão & Sacola de feira \\
\hline Flor artificial & Samambaia pendurada na garagem \\
\hline Fogão à lenha & tacho de cobre \\
\hline Gaiola com passarinho & Talha de barro \\
\hline Gamela de madeira & Tapetinho de croché \\
\hline Garrafa dágua de plástico (abacaxi) & Toalha de mesa de pl'stico decorada \\
\hline Garrafa térmica com café sobre a mesa da cozinha & Toalhinha de crochê \\
\hline Lamparina & Varal suspenso por bambu \\
\hline Lista telefônica & Vaso com árvore da felicidade \\
\hline Máquina de costura & Vaso com comigo-ninguém-pode \\
\hline Máquina de escrever & Vaso com espada de São Jorge \\
\hline Moedor de café & Vassoura de palha \\
\hline Moringa de barro & Violeta no peitorial da janela \\
\hline
\end{tabular}

Tabela 1. Lista dos 58 artefatos típicos sugeridos. Elaborada pela autora em 2014.

Paralelamente aos depoimentos informais, foi feita uma pesquisa piloto por meio de um questionário enviado a sessenta indivíduos adultos indagando sobre suas origens familiares e memórias da infância.

Do total de 42 respondentes, 18 foram descartados em função de não se enquadrarem no recorte social 


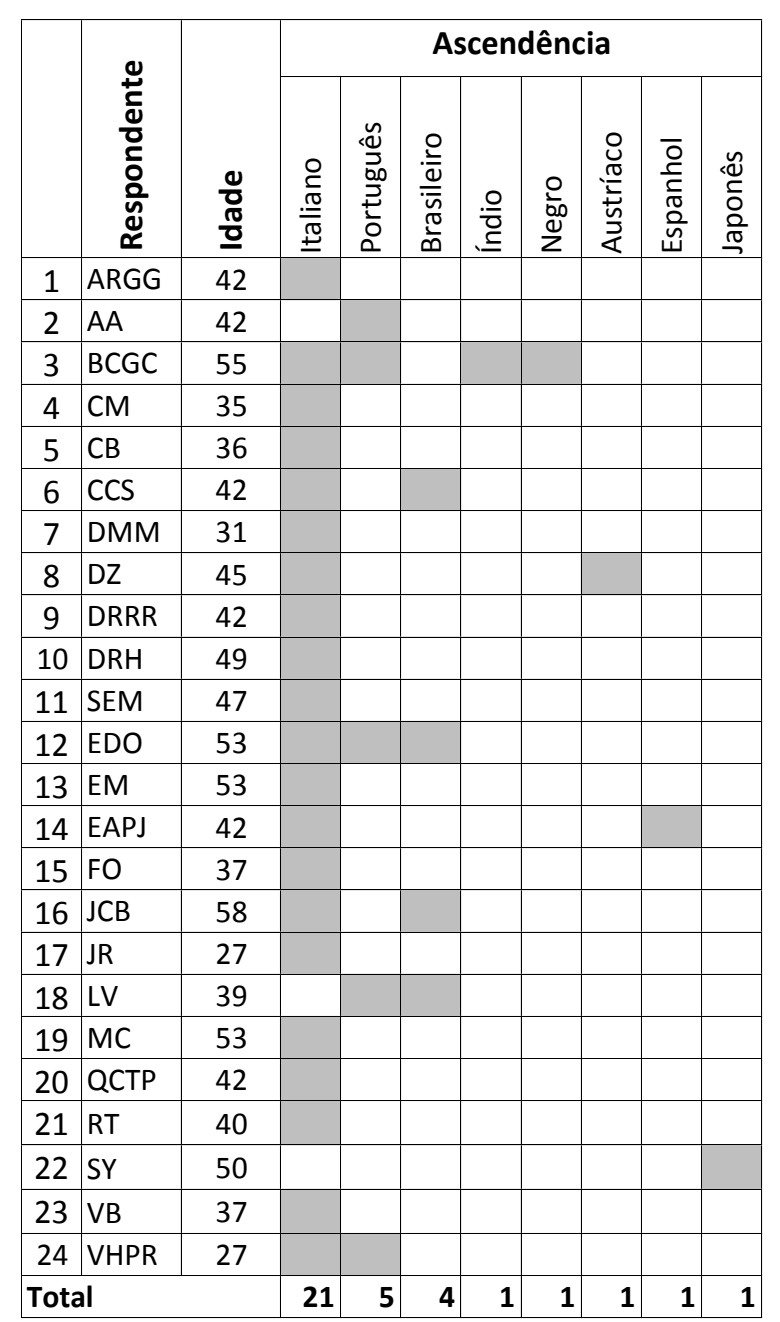

Tabela 2. Ascendência e idade dos entrevistados.

Elaborada pela autora em 2014. da pesquisa, por seus antepassados não serem de origem rural ou popular, ou ainda por serem de outras regiões do país.

Os demais 24 questionários foram considerados válidos e seus respondentes, em sua maioria, descendentes de italianos, cuja faixa etária varia entre 27 e 58 anos, foram posteriormente entrevistados (Tabela 2). Por intermédio de entrevistas semiestruturadas gravadas, foi possível levantar histórias de infância presentes nas memórias destes respondentes e, principalmente, uma série de artefatos que participaram dessas experiências vividas em casa de familiares, bem como os sentimentos atribuídos a eles, permitindo sua caracterização do ponto de vista simbólico.

Esta caracterização auxiliou na formulação das questões a serem investigadas na fase posterior da pesquisa de campo, em busca dos valores simbólicos dos artefatos notáveis.

Tomemos algumas passagens para exemplificar a questão:

\footnotetext{
Tenho na memória afetiva os quadros de parede com fotos antigas e no formato ovalado, em tom amarelo e com moldura em madeira marrom. Sentimento religioso, pois eram imagens de pessoas desconhecidas, mas próximas pelo lastro familiar. As fotos eram dos antepassados e remetiam a um tempo desconhecido. As imagens despertavam curiosidade, incertezas e a sensação de pertencimento. (B. C. G. C., 55 anos)
}

Xícaras de porcelana manchadas de café pelo uso... Eu sentia a sensação de fazer parte de uma família, de um grupo, de não estar só. (E. M., 53 anos)

Nos dois casos acima, nota-se a sensação de pertencimento a um grupo ou família, através da relação com objetos do cotidiano.

Em outras passagens, identifica-se o capricho da dona da casa com o lar, o ato de enfeitar, independentemente da situação financeira da família:

Vasinhos de flores de plástico, com poeira impregnada... tristeza, pela associação à pobreza, mas também demonstração de capricho, por querer enfeitar a casa, mesmo que de maneira simples. (E. M., 53 anos)

Ah, eles eram muito simples, não digo pobre, porque não tinha pobreza na roça, tinha fartura de comida. Mas não tinham dinheiro, era gente muito simples. A casa da minha avó era toda arrumadinha, enfeitada, chei de almofada, paninho florido. (M. C., 53 anos) 
A casa da minha vó era cheia de toalhinhas de crochê impecáveis, lindas... despertou em mim a vontade de aprender a fazer crochê. (C. B., 36 anos)

Eu tinha vontade de ter uma casa bonita quando "fosse grande" e me casasse. (E. M., 53 anos)

Também podemos observar como a comida, tanto o fazer quanto o comer, está impregnada nas lembranças e é rememorada com prazer. Percebe-se que a refeição era um momento de socialização, em volta do qual se reunia a família.

Panelas enormes de ferro, tachos de cobre, onde costumavam fazer pamonhas de milho e assim nos reuníamos com frequência. (V. B.,37 anos)

Na casa da minha avó tinha um fogão a lenha que ficava dentro da cozinha. Lá saíam as melhores comidas, nas panelas de barro, e o cheiro da comida dava pra sentir da rua. Aí a gente entrava correndo, eu e as minhas primas. (D. M. M., 31 anos)

A relação com o tempo aparece em dois momentos diferentes. A respondente Q. C. T. P., ao falar sobre os retratos da avó e tios-avôs na casa de sua avó em Valinhos, ressalta a capacidade do artefato de representar a passagem do tempo.

Lembro também dos quadros de fotos antigas dela e dos meus tios. Sempre achei bonito e gostava de observar como as pessoas mudam ao longo do tempo. (Q. C. T. P., 42 anos)

Por outro lado, o respondente que mora na cidade grande, Campinas, percebe outro ritmo de passagem do tempo em relação às pequenas cidades do oeste do estado, onde vivem seus parentes, como Monte Aprazível, cidade com cerca de 20 mil habitantes, e comenta:

Parece que o tempo na casa dos meus tios e tias tem uma outra velocidade, passa muito mais devagar do que no ambiente em que vivo e trabalho. (M. C., 53 anos)

Algumas falas ilustram como os respondentes, quando crianças, se encantavam com as "engenhocas" encontradas apenas nas casas dos parentes, como os moedores de café ou carne, ou mesmo as ferramentas dos avôs, objetos que não faziam parte do cotidiano em suas casas e que adquiriam um caráter lúdico.

O tio que morava em Botucatu na mesma rua que eu tinha uma verdadeira marcenaria em casa com todas as ferramentas. Eu adorava, pois ele fazia brinquedos pra mim (o meu carrinho de rolemã) e eu ajudava. (J. C. B., 58 anos) Lembro de um galinho que ficava na cozinha da minha tia-avó. Ele mudava de cor de acordo com o clima. (A. R. G. G., 42 anos)

Eu gostava de moer o café, mexer no moedor, tinha a manivela e aquela borboleta, ele ficava preso numa mesa de madeira. Toda hora tinha café, a água ficava quente no bule de metal, no fogão a lenha. Aí moía o café na hora. Era um objeto comum, muito usado. (J. C. B., 58 anos) 
Com base nestes 24 depoimentos, elaborou-se uma segunda lista, intitulada relatos de memória, com 35 itens (Tabela 3).

\begin{tabular}{|l|l|}
\hline \multicolumn{2}{|l|}{ Resultado dos questionários - Relatos de memória } \\
\hline Antigos equipamentos de fazenda & Porcelana decorada \\
\hline Bibelôs de louça, cristal ou vidro & Porta retratos \\
\hline Cabeça de galinha de crochê para bico do bule & Quadros de parede com retratos antigas \\
\hline Caneca de louça de brinde de festa & Rádio \\
\hline Coador de café de pano & Retratos de Cristo de parede \\
\hline Colcha de crochê & Retratos de santos de parede \\
\hline Coleção de garrafinhas de bebida & Tapetes coloridos \\
\hline Ferramentas de marcenaria & Tapetinhos de crochê \\
\hline Ferro de passar roupa à brasa & Terço da avó \\
\hline Filtro de barro & Toalhinhas de crochê \\
\hline Fogão a lenha & Varais suspensos por bambu \\
\hline Frutas de gesso & Vasinhos de flores de plástico \\
\hline Galinho português de previsão do tempo & Vaso feito de pneu velho cortado pintado \\
\hline Imagens de santos (gesso) & Vasos de porcelana decorados (flores) \\
\hline Lembrancinhas de viagens & Vidros com bolachinhas \\
\hline Máquina de costura & Xícara de chá de porcelana decorada \\
\hline Panelas de barro & Xícaras de porcelana manchadas de café \\
\hline Pano de prato decorado com barrado de crochê & \\
\hline
\end{tabular}

Tabela 3. Lista dos 35 artefatos presentes nos relatos de memória. Elaborada pela autora em 2014. 
O passo seguinte foi confrontar a lista dos relatos de memória com a dos artefatos típicos sugeridos, eliminando duplicidades, filtrando possíveis erros de nomenclatura e mantendo todos os artefatos coletados nos dois momentos, o que deu origem ao que se chamou de lista de artefatos memoráveis, com um total de 77 itens (Tabela 4).

\begin{tabular}{|c|c|}
\hline \multicolumn{2}{|l|}{ Artefatos memoráveis } \\
\hline Antigos equipamentos de fazenda & Moedor de café \\
\hline Arranjo de flor artificial & Moedor de carne \\
\hline Bacia de alumínio/galvanizado & Moedor de milho \\
\hline Bíblia & Moringa de barro \\
\hline Bule de café & Panela de barro \\
\hline Calendário - folhinha & Panela de ferro \\
\hline Caneca de ágata & Paneleiro \\
\hline Caneca de alumínio & Pano de prato pintado à mão $\mathrm{c} /$ crochê \\
\hline Caneca de louça de brinde de festa & Pé de Romã \\
\hline Canivete com cabo de madre-perola & Peneira de taquara \\
\hline Canteiro com ervas/temperos & Peneira para grãos \\
\hline Capa de botijão de gás & Penico \\
\hline Carrinho de feira & Pilão \\
\hline Coador de café de pano & Porcelanas decoradas desparceiradas \\
\hline Cobre-prateleira & Potes de vidros decorados (bomboniere) \\
\hline Cobre-talha & Prato porcelana enfeite \\
\hline Colcha /almofada de retalho & Puxa-saco \\
\hline Colcha de crochê & Rádio \\
\hline Comigo-ninguém-pode & Ralador de galvanizado \\
\hline Copo pra café & Relicário/Oratório de santo \\
\hline Copo "bico de jaca" & Retratos antigos de parede \\
\hline Cortina de renda & Retratos de santos/ Cristo \\
\hline Crucifixo & Roseira \\
\hline Espelho de banheiro com moldura abóbora & Samambaia suspensa \\
\hline Ferro à carvão & Santa ceia \\
\hline Filtro de água de barro (talha) & Sapateira \\
\hline Fogão a lenha & Tacho de cobre \\
\hline Gaiola com passarinho/papagaio & Tapetinhos \\
\hline Galinho português de previsão do tempo & Toalha de plástico decorada \\
\hline Gamela de madeira & Toalha de plástico transparente \\
\hline Garrafa d'água de plástico/jarra & Toalhinha de crochê \\
\hline Garrafa de vidro bico de jaca & Torrador de café \\
\hline Garrafa térmica com café & Varal suspenso por bambu \\
\hline Imagens de santos (gesso) & Vaso com árvore da felicidade \\
\hline Jarra de leite & Vaso com espada de São Jorge \\
\hline Lamparina & Vaso de porcelana decorados motivo floral \\
\hline Lista telefônica & Vassoura de palha \\
\hline Máquina de costura & \\
\hline
\end{tabular}




\section{Localização do objeto de pesquisa}

De posse da lista de artefatos memoráveis, a próxima etapa consistiu em uma pesquisa de campo com a finalidade de localizar estes objetos, bem como sua relação simbólica com seus usuários. Nesta etapa, foram feitas vinte visitas a residências de idosos de origem familiar rural, paulistas e de condição social compreendida dentro do contexto da pesquisa. O principal critério de seleção das residências a serem visitadas foi a relação com a tradição rural de seus moradores, que deveriam ter nascido ou vivido no sítio, independentemente de hoje viverem na zona urbana, tanto das pequenas cidades quanto de uma grande região metropolitana como Campinas, por exemplo. As visitas foram feitas em oito cidades do interior do estado, a saber: Monte Aprazível, Rio Claro, Piracicaba, Botucatu, Limeira, Campinas, Laranjal Paulista e São Luís do Paraitinga.

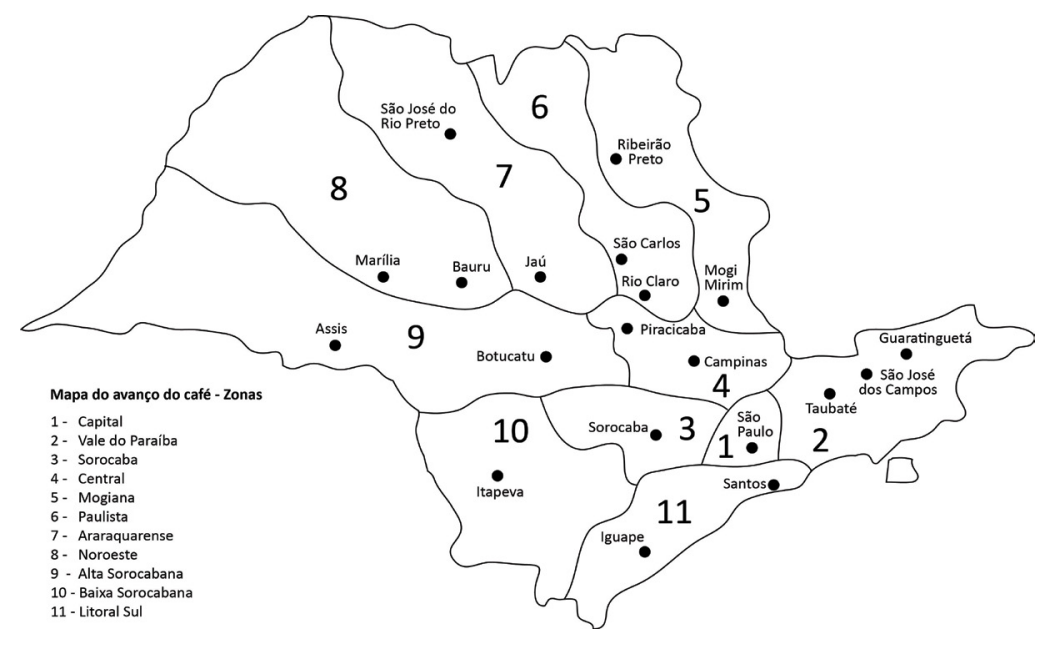

Figura 27. Mapa do avanço do café. (Reproduzido de HOLLOWAY, 1984, p. 64)

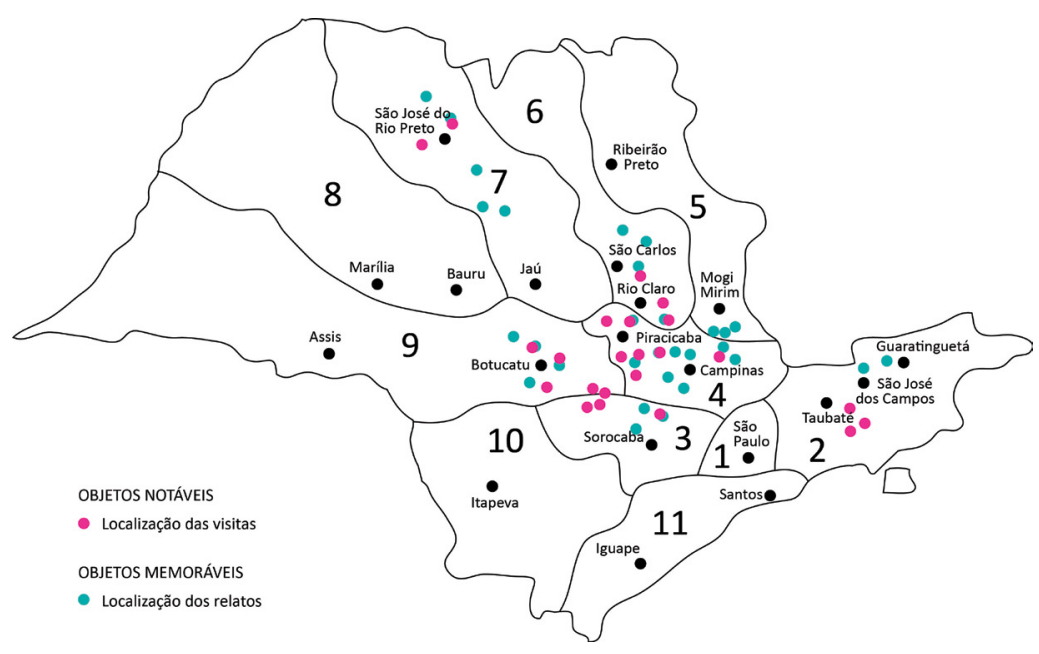

Figura 28. Distribuição das visitas na pesquisa de campo. Elaborado pela autora em 2014.
A amostragem da pesquisa de campo foi definida de modo a atingir regiões representativas do desenvolvimento do estado de São Paulo de acordo com os eixos de expansão da lavoura de café, segundo Halloway (1984), impulsionado pelo desenvolvimento da malha ferroviária no início do século $\mathrm{XX}$ (Figura 27).

Desta forma, procurou-se dividir a pesquisa pelas regiões representativas da história rural do estado de São Paulo, levando-se em consideração também a incidência dos relatos de memória (Figura 28). Das vinte residências visitadas, três estão localizadas em distritos (antigos bairros rurais), seis são propriedades rurais (pequenos sítios) e as onze demais se localizam em áreas

urbanas de cidades que variam de cerca de 20 mil habitantes, como Monte Aprazível, até Campinas, com uma população de cerca de 1 milhão de pessoas. A variedade na amostragem foi para que não se caracterizasse a amostra pelo ambiente onde se encontra a residência.

Dentre as residências visitadas, em oito delas morava o casal de idosos além de algum filho. Em onze, apenas a idosa, viúva ou divorciada, sozinha ou acompanhada pela irmã, filho ou neta. E em apenas uma, encontramos um senhor, divorciado, morando só com um filho há menos de um ano, após sua mãe 
ter falecido, sem, portanto, a presença constante de uma mulher em casa, mas com uma empregada doméstica regular.

A maioria dos entrevistados se declarou descendente de mais de uma nacionalidade - por exemplo, avós paternos espanhóis e maternos italianos, com pai e mãe brasileiros -, declarando-se assim netos de imigrantes. Alguns disseram ser descendentes de brasileiros, mas, na verdade, tratam-se de portugueses já há muito estabelecidos no Brasil e, portanto, já "abrasileirados". Vale notar que dois dos entrevistados declararam-se descendentes de escravos, não se referindo à nacionalidade de seus antepassados e sim à sua condição social (Tabela 5).

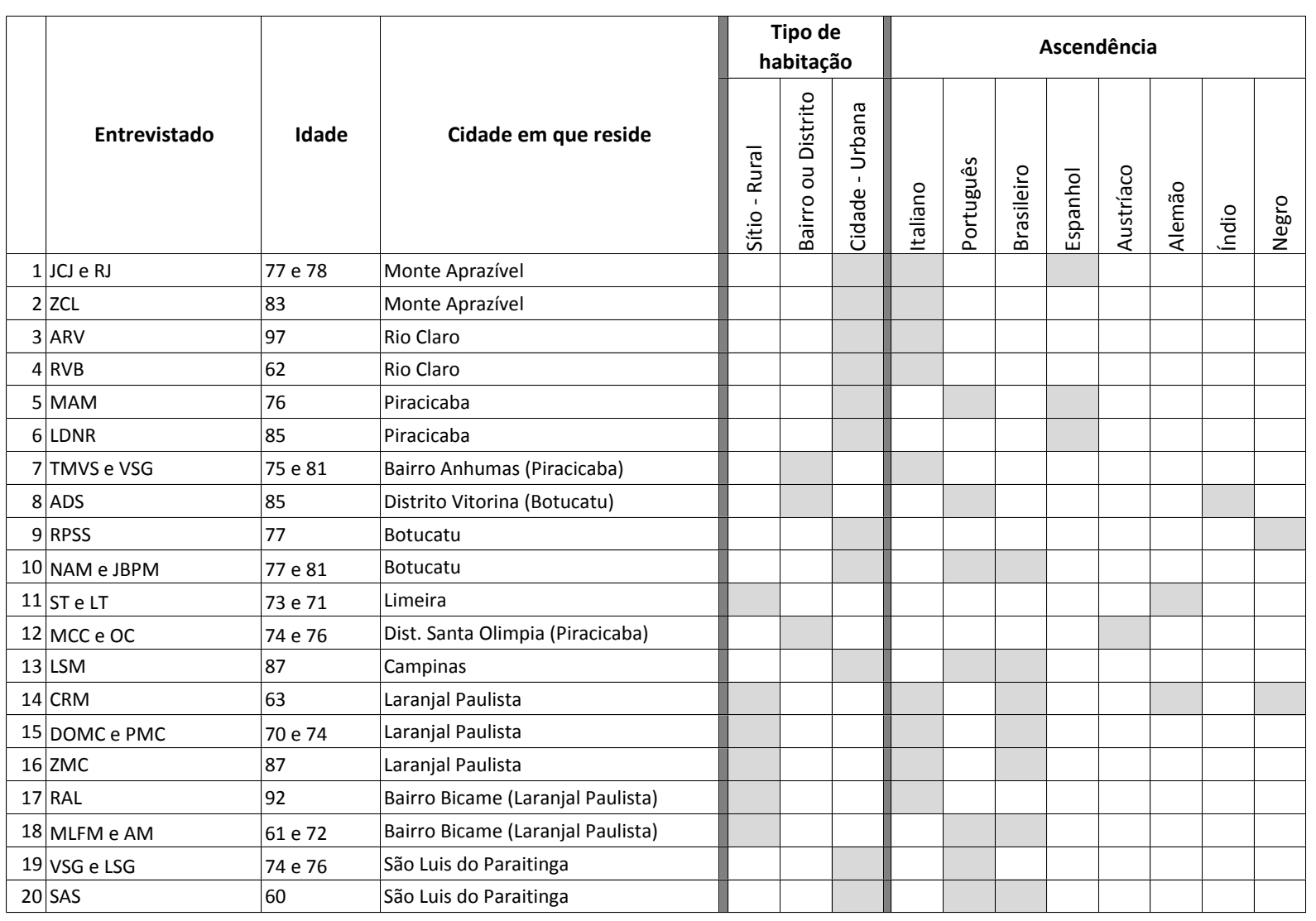

Tabela 5. Idade, local de residência e ascendência dos respondentes. Elaborada pela autora em 2014.

Nas visitas às residências, pudemos observar 71 dos 77 artefatos presentes na lista de artefatos memoráveis, os quais objetos foram fotografados em seu contexto e, através de entrevistas e observação direta, obtivemos alguns dados sobre a relação dos moradores com eles, seus significados para aquelas famílias e possíveis detalhes relevantes para a posterior análise por parte da pesquisadora.

Para tanto, foram elaboradas previamente indagações exploratórias, a fim de guiar as questões feitas aos entrevistados, de modo a compreender a relação dos mesmos com os artefatos. Exemplos de perguntas feitas diretamente aos entrevistados ou questões investigadas através de observação da pesquisadora: qual é a disposição destes artefatos no ambiente doméstico?, quais as características funcionais dos artefatos, como é utilizado, é simples de usar?, qual a origem deste objeto na casa?, foi comprado, presente, herança?, no caso de produtos artesanais, foram feitos por algum membro da família?, qual é a função destes artefatos para os seus usuários?, qual é a relação emocional dos usuários com estes artefatos notáveis?, existe uma noção de status atribuída a estes objetos?, aspectos econômicos são relevantes na escolha destes objetos 
pelos usuários?, estes artefatos têm relação com algum ritual religioso ou de superstição?, estes artefatos têm relação de tradição com o ambiente rural ou urbano? Em alguns casos, foi necessário repetir a visita por falta de alguma informação crucial não coletada da primeira vez.

É importante frisar que foram feitas coletas de depoimentos dos usuários, sendo estes paulistas, idosos e de origem familiar rural, juntamente com o registro fotográfico dos artefatos em seu contexto, sem manipulação do entorno, muitas vezes comprometendo a qualidade da fotografia em detrimento da veracidade do registro.

\section{Seleção dos dados para análise}

De posse do levantamento dos objetos no campo, optou-se por levar para a próxima etapa do estudo, ou seja, para a análise dos dados, apenas aqueles encontrados em três ou mais residências, descartando os objetos encontrados em apenas um ou dois casos, pela não representatividade da ocorrência, resultando um total de 54 artefatos (Tabela 6). 


\begin{tabular}{|c|c|c|c|c|c|c|c|c|c|c|c|c|c|c|c|c|c|c|}
\hline & & & & & & & & & & Visite & s/Res: & pond & entes & & & & & \\
\hline Objetos memoráveis & Observaçžes / Disposiç̧̃o especial & 1 & 2 & 3 & 4 & 5 & 6 & 7 & 8 & 9 & 10 & 11 & 12 & 13 & 14 & 15 & 16 & 17 \\
\hline & & sa & $z \mathrm{CL}$ & ARV & RVB & MAM & LONR & TMvs & ADS & RPSS & NAM & ST & McC & LSM & СRM & Domc & ZMc & RAL \\
\hline Arranjo de flor artificial & & $\mathrm{x}$ & $\mathrm{x}$ & $x$ & & $\mathrm{x}$ & $\mathrm{x}$ & $\mathrm{x}$ & $\mathrm{x}$ & $\mathrm{x}$ & $\mathrm{x}$ & $\mathrm{x}$ & & $\mathrm{x}$ & $\mathrm{x}$ & $\mathrm{x}$ & $\mathrm{x}$ & $\mathrm{x}$ \\
\hline Toalhinha de crochê & Sobre os móveis & $\mathrm{x}$ & $\mathrm{x}$ & $\mathrm{x}$ & $\mathrm{x}$ & $\mathrm{x}$ & $\mathrm{x}$ & $\mathrm{x}$ & $\mathrm{x}$ & $\mathrm{x}$ & $\mathrm{x}$ & & $\mathrm{x}$ & $\mathrm{x}$ & $\mathrm{x}$ & $\mathrm{x}$ & $\mathrm{x}$ & 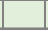 \\
\hline Calendário - folhinha & Atrás da porta da cozinha ou na parede (vários) & & $\mathrm{x}$ & & & $\mathrm{x}$ & $\mathrm{x}$ & $\mathrm{x}$ & $\mathrm{x}$ & $\mathrm{x}$ & $\mathrm{x}$ & $\mathrm{x}$ & & $\mathrm{x}$ & $\mathrm{x}$ & $\mathrm{x}$ & $\mathrm{x}$ & $\mathrm{x}$ \\
\hline Vassoura de palha & & $x$ & $\mathrm{x}$ & $\mathrm{x}$ & & & $\mathrm{x}$ & $\mathrm{x}$ & $\mathrm{x}$ & & & $\mathrm{x}$ & & $\mathrm{x}$ & $\mathrm{x}$ & $\mathrm{x}$ & $\mathrm{x}$ & $\mathrm{x}$ \\
\hline Vaso de porcelana decorados motivo floral & & $\mathrm{x}$ & $\mathrm{x}$ & $\mathrm{x}$ & & $\mathrm{x}$ & $\mathrm{x}$ & & & $\mathrm{x}$ & & & & $\mathrm{x}$ & & $\mathrm{x}$ & $\mathrm{x}$ & $\mathrm{x}$ \\
\hline Imagens de santos & & $x$ & $\mathrm{x}$ & & & & $\mathrm{x}$ & $\mathrm{x}$ & $\mathrm{x}$ & & $\mathrm{x}$ & & $\mathrm{x}$ & & $\mathrm{x}$ & $\mathrm{x}$ & $\mathrm{x}$ & 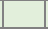 \\
\hline Garrafa térmica com café & Sobre a mesa da cozinha, na bandeja & $\mathrm{x}$ & & $x$ & & $\mathrm{x}$ & $x$ & $\mathrm{x}$ & $\mathrm{x}$ & & $\mathrm{x}$ & $x$ & & $\mathrm{x}$ & & 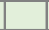 & & $\mathrm{x}$ \\
\hline Porcelanas decoradas desparceiradas & Xicaras ou pratos & $x$ & $\mathrm{x}$ & & & & $\mathrm{x}$ & $\mathrm{x}$ & $\mathrm{x}$ & $\mathrm{x}$ & & $x$ & & - & $\mathrm{x}$ & $\mathrm{x}$ & $\mathrm{x}$ & $\mathrm{x}$ \\
\hline Máquina de costura & Vigorelli ou Singer & $\mathrm{x}$ & & & & $\mathrm{x}$ & $x$ & $\mathrm{x}$ & & $x$ & $x$ & $\mathrm{x}$ & & $\mathrm{x}$ & & $x$ & & $x$ \\
\hline Canteiro com ervas/temperos & No jardim & & $\mathrm{x}$ & $\mathrm{x}$ & & & $x$ & $\mathrm{x}$ & & $x$ & & & $\mathrm{x}$ & $\mathrm{x}$ & $\mathrm{x}$ & & $\mathrm{x}$ & \\
\hline Roseira & No jardim & & $\mathrm{x}$ & $\mathrm{x}$ & & & $\mathrm{x}$ & $\mathrm{x}$ & $\mathrm{x}$ & & & $\mathrm{x}$ & $\mathrm{x}$ & & $\mathrm{x}$ & 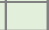 & $\mathrm{x}$ & \\
\hline Pano de prato pintado à mão $\mathrm{c} /$ crochê & Sobre o fogão ou geladeira & $\mathrm{x}$ & & $\mathrm{x}$ & $\mathrm{x}$ & $\mathrm{x}$ & $\mathrm{x}$ & $\mathrm{x}$ & & $\mathrm{x}$ & & & & $\mathrm{x}$ & & 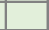 & & 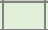 \\
\hline Panela de ferro & & & & & $x$ & & & & $x$ & $x$ & $\mathrm{x}$ & & $\mathrm{x}$ & $\mathrm{x}$ & $\mathrm{x}$ & $\mathrm{x}$ & $x$ & \\
\hline Toalha de plástico decorada & Sobre a mesa da cozinha & $\mathrm{x}$ & $\mathrm{x}$ & 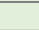 & & $\mathrm{x}$ & & & & $x$ & $x$ & $\mathrm{x}$ & & $x$ & & $x$ & & $\mathrm{x}$ \\
\hline Filtro de água de barro (talha) & Sobre a pia da cozinha & & & $\mathrm{x}$ & & $\mathrm{x}$ & $x$ & & & $x$ & $\mathrm{x}$ & $\mathrm{x}$ & & $\mathrm{x}$ & $\mathrm{x}$ & & - & \\
\hline Cortina de renda & & & & $x$ & & $\mathrm{x}$ & & & & $x$ & $x$ & & $\mathrm{x}$ & $x$ & & 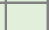 & $\mathrm{x}$ & \\
\hline Bacia de alumínio/galvanizado & Para quarar roupa & $\mathrm{x}$ & & $\mathrm{x}$ & $\mathrm{x}$ & & $\mathrm{x}$ & $\mathrm{x}$ & & $x$ & & $\mathrm{x}$ & & & & 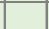 & & $\mathrm{x}$ \\
\hline Retratos de santos/Cristo & Na entrada de casa; na parede & $x$ & $\mathrm{x}$ & $x$ & & $\mathrm{x}$ & $\mathrm{x}$ & $\mathrm{x}$ & $\mathrm{x}$ & & 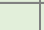 & & & 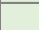 & 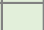 & $x$ & $x$ & \\
\hline Retratos antigos de parede & Formato ovalado ou de moldura trabalhada & & & $\mathrm{x}$ & $x$ & & $x$ & $\mathrm{x}$ & & & $\mathrm{x}$ & $\mathrm{x}$ & & $\mathrm{x}$ & $\mathrm{x}$ & $\mathrm{x}$ & & $\mathrm{x}$ \\
\hline Varal suspenso por bambu & & & & $x$ & $\mathrm{x}$ & $\mathrm{x}$ & $\mathrm{x}$ & & $\mathrm{x}$ & & $\mathrm{x}$ & & & & $\mathrm{x}$ & & & \\
\hline Coador de café de pano & Coa no bule ou no suporte & $x$ & $\mathrm{x}$ & & & & & $\mathrm{x}$ & $x$ & $x$ & $x$ & & 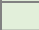 & 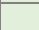 & & $\mathrm{x}$ & & \\
\hline Biblia & Em suporte apropriado de bronze & & & & & & $x$ & $x$ & & $x$ & $\mathrm{x}$ & & $\mathrm{x}$ & $\mathrm{x}$ & & & $\mathrm{x}$ & \\
\hline Caneca de alumínio & & & & & & & $\mathrm{x}$ & & $x$ & $\mathrm{x}$ & $\mathrm{x}$ & $x$ & & & $\mathrm{x}$ & $\mathrm{x}$ & & $\mathrm{x}$ \\
\hline Crucifixo & Sobre a porta/com pedestal & & $\mathrm{x}$ & $\mathrm{x}$ & & & $x$ & $\mathrm{x}$ & & & & & $\mathrm{x}$ & & $\mathrm{x}$ & $x$ & & \\
\hline Comigo-ninguém-pode & Vaso com a planta & $x$ & & $x$ & $\mathrm{x}$ & $\mathrm{x}$ & & $\mathrm{x}$ & & $x$ & & & & $\mathrm{x}$ & & & & \\
\hline Fogão a lenha & & $x$ & & & & & $x$ & & $\mathrm{x}$ & & & & & & $\mathrm{x}$ & $x$ & $x$ & \\
\hline Cobre-talha & Tecido/croché & & & $\mathrm{x}$ & & 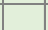 & & & & $\mathrm{x}$ & & $\mathrm{x}$ & & 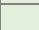 & $\mathrm{x}$ & $\mathrm{x}$ & & $\mathrm{x}$ \\
\hline Relicário/Oratório de santo & & & & & & $\mathrm{x}$ & $\mathrm{x}$ & & & $x$ & $\mathrm{x}$ & & 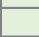 & $\mathrm{x}$ & & & $x$ & \\
\hline Cobre-prateleira & Tecido, com bico de croché, plástico & & $\mathrm{x}$ & & & $\mathrm{x}$ & & 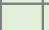 & & $x$ & $\mathrm{x}$ & & $\mathrm{x}$ & & $\mathrm{x}$ & & $\mathrm{x}$ & \\
\hline Tapetinhos & & & & & & & $\mathrm{x}$ & $\mathrm{x}$ & $\mathrm{x}$ & $x$ & & & & & & $\mathrm{x}$ & $\mathrm{x}$ & \\
\hline Potes de vidros decorados (bomboniere) & Com guloseimas & & & $\mathrm{x}$ & & $\mathrm{x}$ & & $\mathrm{x}$ & & $x$ & & & & & 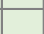 & 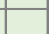 & & $\mathrm{x}$ \\
\hline Bule de café & & & & & & & & & & $x$ & $\mathrm{x}$ & & & & $\mathrm{x}$ & $\mathrm{x}$ & & 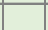 \\
\hline Paneleiro & & & & & & & $x$ & & & $\mathrm{x}$ & $x$ & $x$ & & & & & & $x$ \\
\hline Samambaia suspensa & Em vaso ou xaxim, pendurada na garagem & $\mathrm{x}$ & $\mathrm{x}$ & $\mathrm{x}$ & & & & & & $\mathrm{x}$ & & & & & & & & \\
\hline Tacho de cobre & & $\mathrm{x}$ & & & & & & $\mathrm{x}$ & & $\mathrm{x}$ & & & & $\mathrm{x}$ & & & $\mathrm{x}$ & \\
\hline Rádio & & & & & & & $\mathrm{x}$ & & $x$ & $\mathrm{x}$ & & $\mathrm{x}$ & & & $\mathrm{x}$ & & $\mathrm{x}$ & \\
\hline Caneca de ágata & & & & $\mathrm{x}$ & & & $\mathrm{x}$ & & & $x$ & & & & & $\mathrm{x}$ & $\mathrm{x}$ & & $x$ \\
\hline Copo "bico de jaca" & & $\mathrm{x}$ & & & & $\mathrm{x}$ & & $\mathrm{x}$ & & & $x$ & & & & & & $\mathrm{x}$ & \\
\hline Santa ceia & & $x$ & & $x$ & & & & $\mathrm{x}$ & $\mathrm{x}$ & & & & & & & & & \\
\hline Gaiola com passarinho/papagaio & No beiral do telhado & & & & & & & $\mathrm{x}$ & & & & & $\mathrm{x}$ & $\mathrm{x}$ & $\mathrm{x}$ & & $\mathrm{x}$ & . \\
\hline Prato porcelana enfeite & Desenhos/frases/em suporte & & & & & & & & $x$ & & & & $\mathrm{x}$ & & $\mathrm{x}$ & & & $\mathrm{x}$ \\
\hline Pilão & & & & & & & & & & $\mathrm{x}$ & $\mathrm{x}$ & & & & $x$ & & 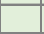 & 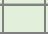 \\
\hline Copo pra café & Junto à garrafa térmica, na bandeja sobre a mesa & $\mathrm{x}$ & & & & & & & $\mathrm{x}$ & $x$ & & & & & & & $\mathrm{x}$ & $\mathrm{x}$ \\
\hline Peneira para grãos & Pendurada do lado de fora da cozinha & $x$ & & & & & & & & $x$ & & $\mathrm{x}$ & & & & $\mathrm{x}$ & & \\
\hline Capa de botijão de gás & Ao lado do fogão (croché/ plástico/ tecido) & & & & & $\mathrm{x}$ & $\mathrm{x}$ & $\mathrm{x}$ & & & & & & & & & & 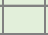 \\
\hline Colcha /almofada de retalho & & & & & & & & & & & $\mathrm{x}$ & & & & & $\mathrm{x}$ & & $\mathrm{x}$ \\
\hline Moedor de café & & $\mathrm{x}$ & & & & & & & & $\mathrm{x}$ & & $\mathrm{x}$ & & & & & & \\
\hline Ferro à carvão & Enfeite & & & & & & $x$ & $\mathrm{x}$ & & $x$ & & & & & & & & \\
\hline Colcha de crochê & & & & & & & $x$ & $x$ & & & & & & $\mathrm{x}$ & & & & \\
\hline Caneca de louça de brinde de festa & Usado como porta-lápis & & $\mathrm{x}$ & & & & & & & & & & $\mathrm{x}$ & & & & & \\
\hline Moedor de carne & & $x$ & & & & & & & & $x$ & & $x$ & & & & & & \\
\hline Galinho português de previsão do tempo & Sobre a geladeira & & & & & $x$ & & & & & & & & & $x$ & & & $x$ \\
\hline Espelho de banheiro com moldura abóbora & & & & & & & & & & $\mathrm{x}$ & & $x$ & & & & & & $x$ \\
\hline Jarra de leite & & & & & & & $\mathrm{x}$ & & & $x$ & & & & $\mathrm{x}$ & & & & \\
\hline Toalha de plástico transparente & Sobre toalha de tecido pra proteger de sujar & & & & & & & $\mathrm{x}$ & & & & & & & & & & $\mathrm{x}$ \\
\hline Vaso com espada de São Jorge & Na entrada de casa & & & & $\mathrm{x}$ & & & & $x$ & & & & & & & & & \\
\hline Torrador de café & Para fogão à lenha & $\mathrm{x}$ & & & & & & & & $x$ & & & & & & & & \\
\hline Ralador de galvanizado & & & & & & & $\mathrm{x}$ & & & & & & & & $x$ & & & \\
\hline Peneira de taquara & Para escolher feijão & & & & & & & & & $x$ & & & & $\mathrm{x}$ & & & & \\
\hline Moringa de barro & & $x$ & & & & & & & & & & & & & $x$ & & & \\
\hline Moedor de milho & & & & & & & & & & $x$ & & $x$ & & & & & & \\
\hline Máquina de fazer macarrão & & $x$ & & & & & & & & & & & & $x$ & & & & \\
\hline Lamparina & & & & & & & & & & $\mathrm{x}$ & & & & & & & & $x$ \\
\hline Garrafa de vidro bico de jaca & Com tampa quadrada & $\mathrm{x}$ & & & & & & $x$ & & & & & & & & & & \\
\hline Sapateira & De pendurar na parede & & & & & & & & & & & & & & & & & $\mathrm{x}$ \\
\hline Puxa-saco & & & & & & $\mathrm{x}$ & & & & & & & & & & & & \\
\hline Penico & & & & & & & & & & & & & & & & & & \\
\hline Garrafa d'água de plástico/jarra & & & & & & $x$ & & & & & & & & & & & & \\
\hline Gamela de madeira & & & & & & & & & & & & & & $\mathrm{x}$ & & & & \\
\hline Carrinho de feira & & & & & & & & & & & & & & & & & $x$ & \\
\hline Canivete com cabo de madre-perola & & & & & & & & & & & & & $x$ & & & & & \\
\hline Vaso com árvore da felicidade & Na entrada de casa & & & & & & & & & & & & & & & & & \\
\hline Péde Romã & No jardim & & & & & & & & & & & & & & & & & \\
\hline Panela de barro & & & & & & & & & & & & & & & & & & \\
\hline Lista telefônica & Na mesinha do telefone & & & & & & & & & & & & & & & & & \\
\hline Antigos equipamentos de fazenda & Enfeites, pendurados & & & & & & & & & & & & & & & & & \\
\hline \begin{tabular}{|l|} 
Anão de jardim \\
\end{tabular} & No jardim & & & & & & & & & & & & & & & & & \\
\hline
\end{tabular}

Tabela 6. Ocorrência dos artefatos na pesquisa de campo. Elaborada pela autora em 2014. 


\section{Análise dos dados}

De posse dos depoimentos e das imagens dos artefatos coletados em campo, a etapa seguinte consistiu no tratamento destes dados de modo a organizá-los para a subsequente análise. Para cada objeto a ser analisado, elaborou-se um painel com os registros fotográficos feitos na pesquisa de campo daqueles espécimes considerados representativos da amostra, de forma a evidenciar seus aspectos constitutivos, bem como outros detalhes específicos de sua materialidade, seu uso ou disposição no ambiente. Junto às imagens, foi acrescentado um texto de apoio, contendo uma breve descrição do objeto e de alguns aspectos formais e plásticos, a função à qual se destina, e algumas particularidades em relação à disposição no ambiente, citações de usuários entrevistados ou outro detalhe relevante para sua análise posterior.

\section{Critérios de análise}

Para a análise dos artefatos, definiram-se critérios que permitissem avaliar o objeto em seu contexto, requisito necessário tanto nos estudos em folclore quanto nos estudos em design, entendendo ambos como fenômenos sociais complexos.

Partindo-se do pressuposto de que estes fenômenos são compostos por códigos com os quais os indivíduos constroem sua rede de significados, optou-se por uma análise com enfoque na semiótica, que "ilumina o processo no qual se dá a construção de um sistema de significação" (NIEMEYER, 2003, p. 14). Considerando-se, portanto, o objeto como signo de uma cultura e o design como formulador de mensagem, baseamos o fundamento teórico em dois autores da semiótica, a fim de compreendermos este processo de atribuição de significados: o semiólogo norte-americano Charles Morris (1970) e o filósofo alemão Max Bense (1971).

Porém, a questão sobre como os indivíduos se relacionam com os objetos ao seu entorno também tem sido amplamente discutida pela psicologia. Desta forma, traçou-se um paralelo com o proposto pelo psicólogo cognitivo Donald Norman (2008) em seu trabalho sobre design emocional e sua classificação dos aspectos do design de acordo com o relacionamento dos indivíduos com os artefatos que os rodeiam em seu cotidiano vivido.

Por fim, interessou-nos olhar a questão sob a ótica do design, enquanto aquele capaz de conduzir as funções dos artefatos em relação aos seus usuários. Entretanto, dentre os objetos analisados, pode-se observar tanto a presença de produtos industriais quanto de objetos artesanais, bem como ao que denominamos design vernacular.

Desta forma, buscamos a classificação do professor de design industrial alemão Bernd Lobach (1981) sobre as funções dos objetos com vistas ao papel do design na interação homem-objeto, considerando que a adoção de um método de análise oriundo do universo do design industrial denota a intenção desta pesquisa em tratar o artefato de design vernacular com a mesma relevância para o campo do design quanto um produto do design industrial.

\section{As dimensões da semiótica}

O semiólogo norte-americano Charles Morris (1970), em Fundations of Theory of Signs (1970), apresenta três níveis de interpretação semiótica largamente adotadas pela linguística e pelo design quando se 
consideram os objetos como portadores de mensagem. A classificação de Morris divide a semiose em três dimensões, de acordo com relações diádicas: a dimensão sintática (relações do signo com outros signos), a dimensão semântica (relações do signo com os seus objetos) e a dimensão pragmática (relações do signo com os interpretantes) (NÖTH, 1995). Esta definição também é adotada por outros autores da semiótica, como Niemeyer (2003), bem como do design, entre eles, Gomes Filho (2006).

A dimensão sintática do objeto pode ser descrita pelo ordenamento de seus elementos constituintes, uma vez que a sintaxe é o conjunto de relações que existe entre as unidades. "É a estrutura do conjunto do produto" (GOMES FILHO, 2006, p. 114).

De acordo com Niemeyer (2003), "a dimensão sintática abrange a estrutura do produto e o seu funcionamento técnico. A estrutura consiste das partes e do modo como elas estão conectadas umas às outras." Para a autora,

a sintaxe inclui tanto a análise da construção técnica do produto quanto a análise de detalhes visuais como juntas, aberturas, orifícios, superposições, texturas, desenhos e cores. Estes detalhes também podem ser descritos como aspectos da composição formal, como simplicidade e complexidade da forma como um todo, simetria, equilíbrio, dinamismo e ritmo (NIEMEYER, 2003, p. 46).

Assim, a dimensão sintática do objeto tem relação com a sua composição e a sua organização físico-estrutural, visual e estético-formal e de suas inter-relações sistêmicas.

Já a dimensão semântica é "a dimensão do próprio objeto e da coisa significada. É a significação do produto" (GOMES FILHO, 2006, p. 115). "As qualidades expressiva e representacional de um produto são os aspectos centrais da dimensão semântica. A dimensão semântica agrega aspectos de referência à dimensão sintática" (NIEMEYER, 2003, p. 49). Assim, compreende-se que a dimensão semântica tem relação com o significado do objeto e o que ele pode significar naquele contexto.

A dimensão pragmática "é a dimensão lógica, são as leis funcionais de utilidade do objeto, envolve sua descrição técnica, construtiva, padrões ergonômicos, tecnológicos, e assim por diante" (GOMES FILHO, 2006, p. 115). Tem relação com a utilidade, o uso e as leis de funcionamento do objeto, bem como sua funcionalidade.

O alemão Max Bense - filósofo com formação em física e matemática e ex-professor da HfG/Höchschule für Gestaltung, a chamada Escola Superior da Forma, em Ulm -, em sua teoria sobre a estética do objeto artístico intitulada Aesthetik, escrita entre 1954 e 1960, retoma a tríade semiótica de Charles Pierce para reformular a análise diádica de Morris e acrescenta uma quarta dimensão ao objeto, a dimensão material. Niemeyer (2003) pontua a correlação entre as classificações de Morris e Bense. Ao que Morris designa dimensão sintática, Bense chama de dimensão técnica ou construtiva; a dimensão semântica, o autor intitula dimensão da forma; a dimensão pragmática é chamada de dimensão de uso; e uma quarta categoria é criada, chamada hílico, ou dimensão material (NIEMEYER, 2003).

Para a autora, a dimensão material não deve constituir uma categoria separada em um estudo de semiótica aplicada ao design, ao que concordamos, argumentando que "as propriedades materiais só são consideradas quando articuladas com as outras dimensões porque não se trata aqui da composição química, durabilidade ou outras características semelhantes do material" (NIEMEYER, 2003, p. 50). A dimensão material refere-se ao material que constitui o produto, sendo, portanto, objetiva e capaz de 
influenciar as demais dimensões, pelo fato de cada material carregar diferentes significados, o que modifica a leitura, conforme o repertório do intérprete.

\section{A psicologia do objeto}

A classificação proposta pelo psicólogo cognitivo Donald Norman (2008) considera que os objetos podem ser avaliados sob três aspectos: visceral, comportamental e reflexivo. O aspecto visceral diz respeito aos atributos físicos do objeto, ao primeiro impacto deste em nós. Por exemplo, a aparência de um objeto que chama a atenção na prateleira da loja. É possível, novamente, estabelecermos um paralelo com a função estética e a dimensão sintática do objeto.

Já o aspecto que o autor chama de comportamental, diz respeito ao uso, objetivamente à sua função e à sua eficácia, como é sua usabilidade do ponto de vista funcional, a facilidade e o prazer de operá-lo, que são as características da dimensão pragmática e da função prática do objeto.

Por fim, o aspecto reflexivo do objeto diz respeito ao caráter subjetivo, à relação de significados que atribuímos ao objeto; abrange particularidades culturais e individuais, memória afetiva e outros aspectos intangíveis (NORMAN, 2008), atributos de sua função simbólica ou da dimensão semântica do objeto.

\section{As funções do objeto}

A terceira classificação da qual nos valemos como referência vem do professor de design industrial alemão Bernd Löbach (1981) que, na década de 1970, abordou os aspectos estéticos e subjetivos do design industrial de maneira didática, criando uma classificação para as funções dos produtos e sua relação com os usuários. O autor propõe que se classifique as funções básicas dos objetos e suas inter-relações com os usuários de acordo com três categorias: função prática, função estética e função simbólica. Esta classificação também é adotada por Gomes Filho (2006).

Compreende-se por função prática "todas as relações entre um produto e seus usuários que se situam no nível orgânico-corporal, isto é, fisiológicas" (LOBACH, 2001, p. 58), ou seja, as funções práticas são todos os aspectos fisiológicos de uso. Esta função está relacionada à adequação do produto às necessidades fisiológicas de uso como, por exemplo, facilidade de uso, conforto, segurança e eficácia de utilização. Entende-se que a função prática tem estreita relação com a dimensão pragmática do objeto, uma vez que está vinculada ao seu uso.

A função estética "é a relação entre um produto e um usuário no nível dos processos sensoriais. [...] A função estética dos produtos é um aspecto psicológico da percepção sensorial durante o seu uso" (LOBACH, 2001, p. 59). "É o aspecto psicológico da percepção multissensorial que tem como atributo principal a fruição da beleza, do prazer e do bem-estar contemplativo em relação a um dado objeto, por parte do usuário" (GOMES FILHO, 2006, p. 43) e está subordinada a aspectos culturais como o repertório, o conhecimento e as vivências do usuário. Está intimamente ligada à função simbólica e às dimensões semióticas do objeto, bem como às noções ergonômicas e aos princípios da organização visual da Gestalt (GOMES FILHO, 2006). Neste sentido, é possível estabelecer um paralelo com a dimensão sintática do produto.

Por fim, a função simbólica é quando "a espiritualidade do homem é estimulada pela percepção deste 
objeto, ao estabelecer ligações com suas experiências e sensações anteriores. [...] A função simbólica dos produtos é determinada por todos os aspectos espirituais, psíquicos e sociais do uso," (LOBACH, 2001, p. 64, grifo do autor). "Envolve fatores sociais, culturais, políticos e econômicos e, também, associa-se a valores pessoais, sentimentais e emotivos" (GOMES FILHO, 2006, p. 44).

É importante acrescentar que, apesar de Löbach (2001) e Gomes Filho (2006) utilizarem esta classificação em relação a objetos industriais, compreendemos que seus critérios de análise possam ser aplicados para quaisquer categorias de objeto, sejam eles objetos artesanais ou mesmo objetos naturais, como um vaso de planta, por exemplo, a partir do momento em que houver uma interação entre o usuário e o objeto em questão.

\section{Cruzando as classificações}

Agrupando-se as dimensões ou aspectos das abordagens citadas, percebe-se afinidades relativas ao uso, ao significado e à percepção dos objetos, termos que serão adotados para nomear as categorias de análise da nossa pesquisa. Ao adotarmos para fins metodológicos uma nomenclatura própria, evidenciamos nosso objetivo de não priorizar nenhuma das classificações estudadas e, sim, abarcar de modo mais abrangente possível os pontos suscitados pelos autores. A Tabela 7 mostra as classificações por autor e as interseções que consideramos pertinentes.

\begin{tabular}{|c|c|c|c|c|c|}
\hline \multirow{4}{*}{ 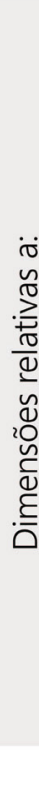 } & $\stackrel{\ominus}{\lrcorner}$ & $\begin{array}{l}\text { Função Prática } \\
\text { - aspectos fisiológicos } \\
\text { de uso } \\
\text { - conforto } \\
\text { - segurança }\end{array}$ & $\begin{array}{l}\text { Aspecto Comportamental } \\
\text { - eficácia } \\
\text { - usabilidade } \\
\text { - prazer e facilidade de } \\
\text { operar }\end{array}$ & $\begin{array}{l}\text { Dimensão Pragmática } \\
\text { - utilidade } \\
\text { - padrões ergonômicos } \\
\text { e tecnológicos } \\
\text { - funcionalidade }\end{array}$ & $\begin{array}{l}\text { Dimensão do uso } \\
\text { - pragmática }\end{array}$ \\
\hline & $\begin{array}{l}\frac{0}{0} \\
\frac{\mathrm{U}}{\mathrm{U}} \\
\frac{\mathrm{U}}{\mathrm{U}} \\
\text { n }\end{array}$ & $\begin{array}{l}\text { Função Simbólica } \\
\text { - aspectos espirituais } \\
\text { e psíquicos de uso } \\
\text { - relações com } \\
\text { experiências e } \\
\text { sensações anteriores }\end{array}$ & $\begin{array}{l}\text { Aspecto Reflexivo } \\
\text { - significados atribuídos } \\
\text { - particularidades } \\
\text { culturaise individuais } \\
\text { - memória afetiva }\end{array}$ & $\begin{array}{l}\text { Dimensão Semântica } \\
\text { • significação } \\
\text { • representação } \\
\text { • expressão }\end{array}$ & $\begin{array}{l}\text { Dimensão da forma } \\
\text { - semântica }\end{array}$ \\
\hline & 过 & $\begin{array}{l}\text { Função Estética } \\
\text { - percepção } \\
\text { - sensorial } \\
\text { - prazer contemplativo }\end{array}$ & $\begin{array}{l}\text { Aspecto Visceral } \\
\text { - aspectos físicos } \\
\text { - aparência }\end{array}$ & $\begin{array}{l}\text { Dimensão Sintática } \\
\text { - estrutura do objeto } \\
\text { - relação entre as } \\
\text { partes e com o todo } \\
\text { - composição formal }\end{array}$ & $\begin{array}{l}\text { Dimensão técnica } \\
\text { ou construtiva } \\
\text { - sintaxe } \\
\text { Dimensão Material } \\
\text { - hílico }\end{array}$ \\
\hline & & Lobach & Norman & Morris & Bense \\
\hline
\end{tabular}

Tabela 7. Critérios para a análise dos artefatos. Elaborada pela autora em 2014

\section{Detalhando as categorias de análise}

As categorias investigadas dentro das três dimensões relativas à percepção, ao significado e ao uso foram definidas, primeiramente, baseando-se em uma análise piloto da amostra e de acordo com os dados coletados nas entrevistas. Observando os painéis dos objetos e as anotações feitas durante as visitas às 
residências, listamos características materiais relativas a formas, cores e acabamentos, por exemplo.

Em relação aos aspectos simbólicos e funcionais, selecionamos termos inseridos nos depoimentos, além de anotações feitas pela pesquisadora observando os entrevistados utilizarem alguns dos artefatos durante as visitas, de forma a criar os campos a serem preenchidos na análise.

Finalmente, acrescentamos algumas características observadas com os levantamentos bibliográficos e iconográficos, bem como as visitas a museus e exposições, realizados com a intenção de se caracterizar o universo material da pesquisa para confrontar os objetos de hoje com os do passado. Exemplo: devido à alta incidência de cestarias e outros objetos feitos de taquara ou cipó encontrados nos glossários das obras de Amadeu Amaral, Cornélio Pires e Valdomiro Silveira, acrescentamos o campo "fibras naturais" na categoria "matéria-prima".

Para caracterizar aspectos de composição formal, utilizamos pares de atributos contrastantes, seguindo os fundamentos da sintaxe visual de Dondis (2007), que classifica o contraste como uma técnica fundamental na composição visual. "O contraste é um instrumento, uma técnica e um conceito [...]. Em termos básicos, nossa compreensão do liso é mais profunda quando o contrapomos ao áspero." (DONDIS, 2007, p. 119). Desta forma, definimos sete pares de atributos contrastantes para submeter nossos artefatos à análise: simplicidade/ complexidade; equilíbrio/ instabilidade; regularidade/ irregularidade; economia/ profusão; minimização/ exagero; unidade/ fragmentação; singularidade/ justaposição.

Com relação aos aspectos relativos ao uso, além das funções desempenhadas pelo artefato na residência, interessou-nos identificar o motivo de se usar aquele objeto para desempenhar aquela função específica. Este questionamento ajuda a compreender algumas questões simbólicas, dada a aproximação da dimensão de uso com a dimensão simbólica do objeto.

Outras duas categorias em relação ao uso foram criadas, a fim de investigarmos características relativas à ergonomia e à usabilidade dos objetos. Para tanto, utilizamos o conceito de manejo definido como

o conjunto de atos físicos que se relaciona com o uso ou a operacionalidade de qualquer produto. Contempla desde operações muito simples às mais complexas (aquelas que exijam ou impliquem séries ou sequências operacionais mais prolongadas) por parte de um usuário ou grupo de usuários. (GOMES FILHO, 2006, p. 74)

Deste modo, classificamos os artefatos em seis categorias, de acordo com o nível de exigência da ação de manejo solicitada para a execução da tarefa: (1) baixíssima, em que a exigência da ação de manejo e controle é muito pequena como, por exemplo, abrir uma porta; (2) baixa, em que a exigência é pequena como, por exemplo, apertar um parafuso; (3) média, em que a exigência é intermediária como, por exemplo, andar de bicicleta; (4) alta, em que a exigência é um pouco maior, como dirigir um automóvel; (5) altíssima, em que a exigência da ação de manejo e controle é muito maior, como pilotar um avião, por exemplo (GOMES FILHO, 2006). Em função de um grande número de artefatos com os quais não há interação na operação, como os enfeites, por exemplo, criamos um campo intitulado não se aplica (7).

Na sequência, buscamos também entender se aquele artefato requer conhecimento prévio para ser utilizado ou se seu uso é intuitivo.

Com relação à análise do significado dos objetos, as categorias foram definidas de acordo com os depoimentos dos entrevistados sobre o que aquele artefato representava ou simbolizava para o depoente. A partir de seus relatos, elaboramos uma lista de conceitos e valores associados aos objetos, organizados 
em dezenove diferentes características conceituais como devoção, fé, crença religiosa, superstição, amor familiar, cuidado/capricho com a casa, proteção, entre outras.

Finalmente, julgamos necessário organizar os dados relativos à forma de aquisição dos artefatos, pois percebemos que, em alguns casos, existia uma relação entre seu significado e o modo como foi adquirido. Assim, elaboramos oito categorias para análise e catalogação das informações a respeito da origem do objeto na casa como, por exemplo, se este foi comprado, presente ou herança, bem como o tipo de local onde $\mathrm{o}$ artefato foi adquirido.

Esta proposta de classificação permitiu-nos olhar de forma detalhada e abrangente o artefato em si, sua materialidade, sua composição como um todo e as partes que o compõe, detalhes visuais e construtivos, bem como as relações com seus usuários, tanto operacionais relativas à sua funcionalidade quanto simbólicas e os significados atribuídos aos objetos.

Lembramos que os aspectos descritos acima não são categorias independentes, pois representam relações sígnicas interligadas.

\section{Fichas de análise dos artefatos}

Para a análise dos artefatos, foram criadas fichas para as três dimensões elucidadas: percepção, significado e uso. Por razões metodológicas, foi preciso dividir a dimensão percepção em duas fichas, deixando os itens cores e texturas em separado, além de criar uma ficha independente para as questões relativas à forma de aquisição dos objetos.

A seguir, apresentamos as cinco fichas, com suas categorias e subcategorias já preenchidas para os 54 artefatos notáveis.

A primeira ficha (Tabela 8) analisou atributos relativos à percepção dos objetos, agrupados por semelhança: identifica-se a matéria-prima de que ele é feito, além dos detalhes plásticos do material, ou seja, seu acabamento. Em seguida, interessou-nos identificar o tipo de produção, se artesanal ou industrial, pressupondo que o processo tenha relação com a estética destes objetos. Por fim, classificamo-los de acordo com sua forma, dividida em duas subcategorias, orgânica ou geométrica, e depois sua composição formal utilizando pares de atributos contrastantes (DONDIS, 2007, p. 119).

A segunda ficha de análise (Tabela 9), também faz parte da dimensão percepção e incluiu a categoria cores e padrões e as subcategorias matiz e textura, estampa e degradê. Esta categoria foi transferida para outra tabela apenas em função de uma melhor organização dos dados.

A terceira ficha de análise (Tabela 10) é da dimensão do uso e, por meio dela, foi possível analisar aspectos comportamentais (NORMAN, 2008) do objeto, reconhecer suas características funcionais e atributos de usabilidade e ergonomia (LOBACH, 2001) (GOMES FILHO, 2006). Para tanto, elencou-se quatro categorias com suas respectivas subcategorias.

A quarta ficha (Tabela 11) analisou os significados dos artefatos para seus usuários, relativos à dimensão semântica dos objetos e aos aspectos reflexivos dos mesmos. Nesta etapa, interessou-nos aspectos simbólicos dos objetos, o que estes representam enquanto valores pessoais ou sociais, bem como a mensagem transmitida por aqueles objetos aos seus usuários ou grupos de pessoas em volta deles. 
Desta maneira, elencou-se dezenove subcategorias.

Finalmente, a última ficha (Tabela 12) organizou as questões relativas à origem do artefato na casa, como foi sua aquisição - se comprado, herdado ou recebido como presente - e ainda o tipo de estabelecimento comercial no caso de ter sido comprado. Como já dito, a intenção desta tabela foi organizar os dados a respeito da origem do objeto na casa, ou seja, sua proveniência, com o intuito de compreender melhor as relações simbólicas dos usuários com os objetos, não tendo a intenção de ser uma análise profunda sobre hábitos do consumidor. 


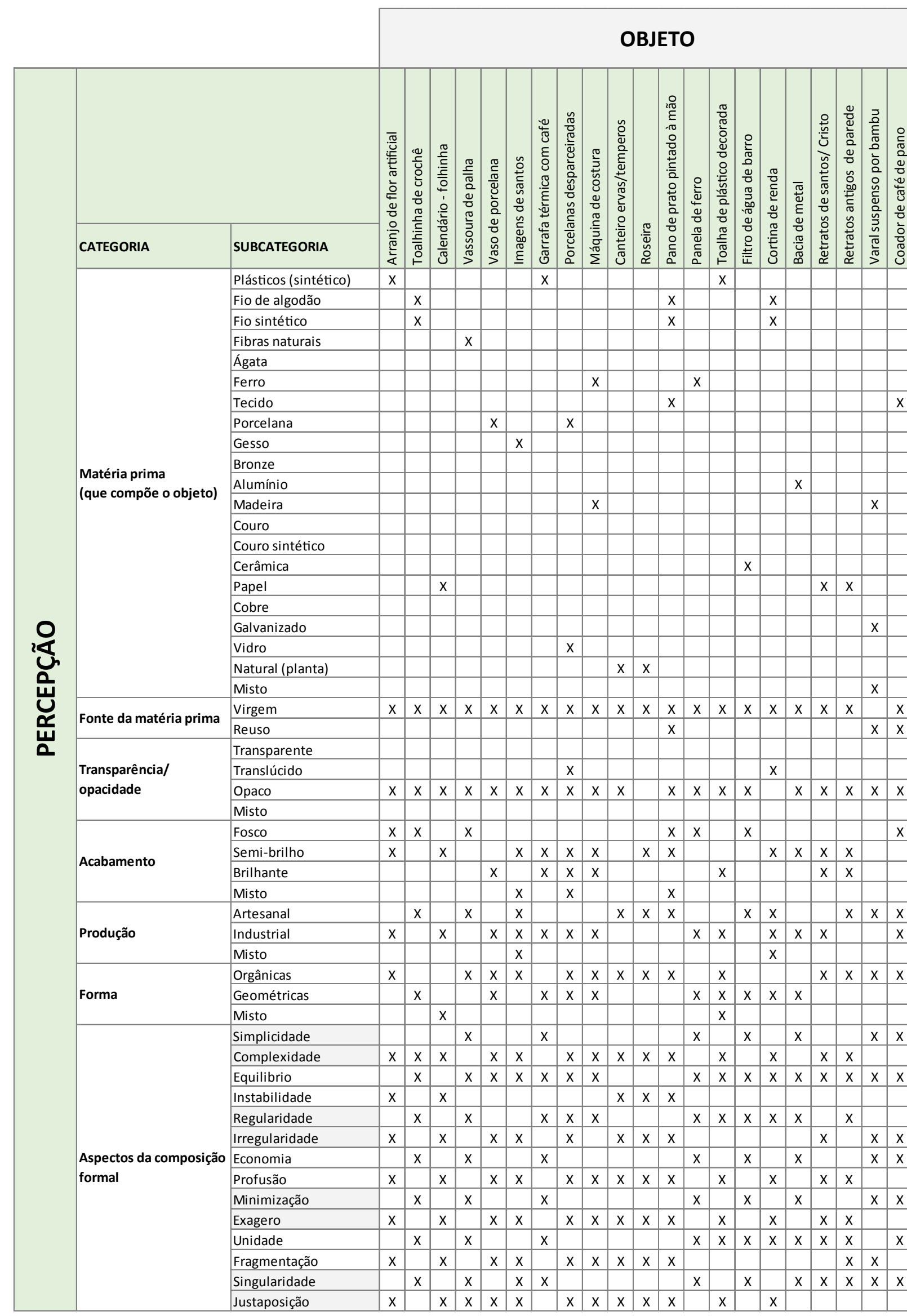

Tabela 8. Ficha de análise da dimensão percepção . Elaborada pela autora em 2014. 
OBJETO

\begin{tabular}{|c|c|c|c|c|c|c|c|c|c|c|c|c|c|c|c|c|c|c|c|c|c|c|c|c|c|c|c|c|c|c|c|c|c|c|}
\hline$\frac{\frac{\sqrt{0}}{0}}{\frac{0}{0}}$ & 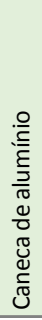 & 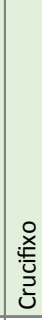 & 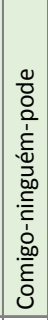 & 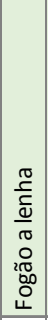 & 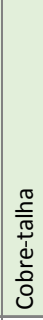 & 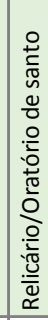 & 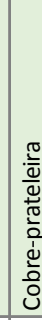 & 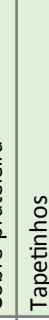 & 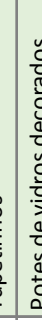 & 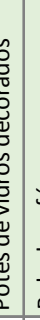 & 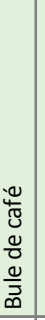 & 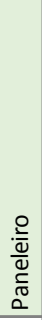 & 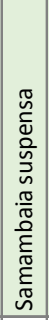 & 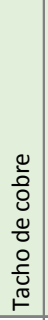 & 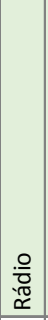 & 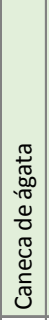 & 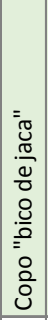 & 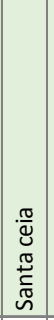 & 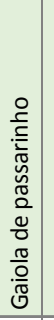 & 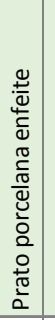 & $\begin{array}{c}0 \\
\frac{20}{2} \\
\frac{20}{2}\end{array}$ & $\begin{array}{l}\frac{\pi}{0} \\
\frac{0}{0} \\
\frac{\pi}{0} \\
\overline{0} \\
\frac{\pi}{0} \\
\frac{0}{0} \\
0 \\
0 \\
0\end{array}$ & 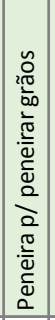 & 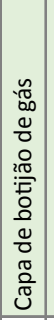 & 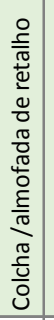 & 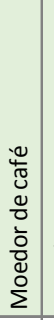 & 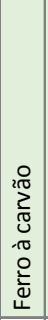 & 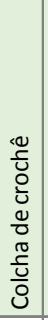 & 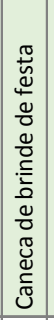 & 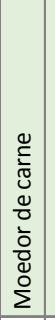 & 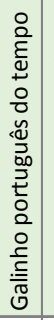 & 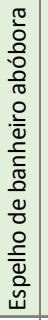 & 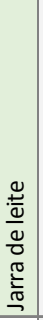 & $\begin{array}{l}\frac{1}{6} \\
\stackrel{\circ}{\circ}\end{array}$ \\
\hline & & $x$ & & & & & $x$ & & & & & & & & $\mathrm{x}$ & & & & & & & & & & & & & & & & $x$ & $x$ & & 8 \\
\hline & & & & & $x$ & & $x$ & $x$ & & & & & & & & & & & & & & & & $x$ & & & & $x$ & & & & & & 8 \\
\hline & & & & & $x$ & & $x$ & $x$ & & & & & & & & & & & & & & & & $x$ & & & & $x$ & & & & & & 8 \\
\hline & & & & & & & & & & & & & & & & & & & & & & & & & & & & & & & & & & 1 \\
\hline & & & & & & & & & & & $X$ & & & & & $x$ & & & & & & & & & & & & & & & & & & 2 \\
\hline & & & & $x$ & & & & & & & $x$ & $x$ & & & & $x$ & & & & & & & & & & $x$ & $x$ & & & $x$ & & & & 9 \\
\hline & & & & & $X$ & & $x$ & $x$ & & & & & & & & & & & & & & & & $x$ & $x$ & & & & & & & & & 7 \\
\hline & & & & & & & & & & & $X$ & & & & & & & & & $X$ & & & & & & & & & $x$ & & & & $x$ & 6 \\
\hline & & $x$ & & & & & & & & & & & & & & & & $x$ & & & & & & & & & & & & & & & & 3 \\
\hline & & $x$ & & & & & & & & & & & & & & & & & & & & & & & & & & & & & & & & 1 \\
\hline & $x$ & $x$ & & & & & & & & & $x$ & $x$ & & & & & & & & & & & & & & & & & & & & & & 5 \\
\hline & & $x$ & & & & $x$ & & & & & & $x$ & & & & & & & $x$ & & $x$ & & $x$ & & & & & & & & & & & 8 \\
\hline & & & & & & & & & & & & & & & & & & & & & & & & & & & & & & & & & & 0 \\
\hline$X$ & & & & & & & & & & & & & & & & & & & & & & & & & & & & & & & & & & 1 \\
\hline & & & & $x$ & & & & & & & & & & & & & & & & & & & & & & & & & & & & & & 2 \\
\hline$X$ & & & & & & & & & & & & & & & & & & $X$ & & & & & & & & & & & & & & & & 5 \\
\hline & & & & & & & & & & & & & & $x$ & & & & & & & & & & & & & & & & & & & & 1 \\
\hline & & & & & & & & & & & & & & & & & & & $x$ & & & & $x$ & & & & & & & & & & & 3 \\
\hline & & & & & & & & & & & & & & & & & $x$ & & & & & $x$ & & & & & & & & & & $x$ & & 4 \\
\hline & & & $x$ & & & & & & & & & & $x$ & & & & & & & & & & & & & & & & & & & & & 4 \\
\hline & & $x$ & & & & & & & $x$ & $x$ & & & & & & & & & & & & & & & & & & & & & $x$ & & & 4 \\
\hline$X$ & $x$ & $x$ & $x$ & $x$ & $x$ & $x$ & $x$ & $x$ & & & $x$ & $x$ & $\mathrm{X}$ & $X$ & $x$ & $x$ & $x$ & $x$ & $x$ & $\mathrm{X}$ & $x$ & $\mathrm{X}$ & $x$ & $X$ & & $x$ & $x$ & $x$ & $X$ & $\mathrm{X}$ & $x$ & $x$ & $X$ & 51 \\
\hline & & & & & & $x$ & & $x$ & $x$ & $x$ & & & & & & & & & & & & $x$ & & $x$ & $x$ & & & & & & & & & 9 \\
\hline & & & & & & & & & $x$ & $x$ & & & & & & & $x$ & & & & & $x$ & & & & & & & & & & & & 3 \\
\hline & & & & & & & $x$ & & $x$ & $x$ & & & & & & & & & $x$ & & & & $x$ & $x$ & & & & $x$ & & & & & & 8 \\
\hline$x$ & $x$ & $x$ & $x$ & $x$ & $x$ & $x$ & $x$ & $x$ & & & $x$ & $x$ & $x$ & $x$ & $x$ & $x$ & & $x$ & & $x$ & $x$ & & & $x$ & $x$ & $x$ & $x$ & $x$ & $x$ & $x$ & $x$ & $x$ & $x$ & 47 \\
\hline & & & & & & & & & $x$ & $x$ & & & & & & & & & & & & & & & & & & & & & & & & 1 \\
\hline$X$ & & & & $x$ & & $x$ & $x$ & $x$ & & & & $x$ & & $x$ & & & & & & & $x$ & & $x$ & $x$ & $x$ & $x$ & $x$ & $x$ & & $x$ & $X$ & $x$ & & 24 \\
\hline & $x$ & & & & & $x$ & $x$ & & $x$ & $x$ & $x$ & & & & & & & $x$ & $x$ & & & & & & & & & $x$ & & & & & & 20 \\
\hline & & $x$ & & & & $x$ & & & $x$ & & $x$ & $x$ & & $x$ & & $x$ & & & & $x$ & & & & & $x$ & & & & $x$ & & & & $x$ & 18 \\
\hline & & $x$ & $x$ & & & $x$ & & & & & & & & & $x$ & & & & & & & & & & & & & $x$ & & & & & & 8 \\
\hline & & & $x$ & $x$ & $X$ & $x$ & $x$ & $x$ & $x$ & & & $x$ & $x$ & $x$ & & & & $x$ & & $\mathrm{x}$ & $x$ & & & $x$ & $x$ & & & $x$ & & & & & & 27 \\
\hline$x$ & $x$ & $x$ & & $x$ & & & & & $x$ & $x$ & $x$ & $x$ & & & $x$ & $x$ & $x$ & & $x$ & $x$ & & $x$ & $x$ & & & $x$ & $x$ & & $x$ & $x$ & $x$ & $x$ & $x$ & 34 \\
\hline & & & & $x$ & & & & & & & & & & & & & & & & & & & & & & & & & & & & & & 3 \\
\hline & & $x$ & $x$ & & $x$ & & & & & & $x$ & & $x$ & & & & & $x$ & & $x$ & & & & $x$ & & & & & $x$ & & $x$ & & & 24 \\
\hline$X$ & $x$ & & & $x$ & & $x$ & $x$ & $x$ & & & $x$ & $x$ & & $x$ & $x$ & $x$ & $x$ & & $x$ & & $x$ & $x$ & $x$ & & $x$ & $x$ & $x$ & $x$ & $\mathrm{x}$ & $x$ & & $x$ & $X$ & 34 \\
\hline & & & & & & & & & & & & & & & & $x$ & & & & & & & & & & & & & $X$ & & & & & 4 \\
\hline$x$ & $x$ & & $x$ & $x$ & $x$ & $x$ & $x$ & & & & $x$ & $x$ & $x$ & $x$ & & $x$ & & & $x$ & & $x$ & $x$ & $\mathrm{x}$ & $x$ & & $x$ & $x$ & & & & & $x$ & & 27 \\
\hline & & $x$ & & & $x$ & $x$ & & $x$ & $x$ & & & & & & $x$ & & $x$ & $x$ & & $x$ & & & & & $x$ & & & $x$ & $x$ & $\mathrm{X}$ & $x$ & & $x$ & 29 \\
\hline$x$ & $x$ & $x$ & $x$ & & $x$ & $x$ & $x$ & $x$ & & & $x$ & $x$ & $x$ & $x$ & $x$ & $x$ & $x$ & $x$ & $x$ & $x$ & $x$ & $x$ & $x$ & $x$ & & & $x$ & $x$ & & & $x$ & $x$ & $x$ & 43 \\
\hline & & & & $x$ & & & & & $x$ & & & & & & & & & & & & & & & & $x$ & $x$ & & & $x$ & $x$ & & & & 11 \\
\hline$X$ & $x$ & & & & $x$ & & $x$ & $x$ & & & & $x$ & $x$ & $x$ & & $x$ & $x$ & & $x$ & & $x$ & $x$ & $x$ & $x$ & $x$ & & & $x$ & & & & $x$ & & 29 \\
\hline & & $x$ & $x$ & $x$ & & & & $x$ & $x$ & $x$ & $x$ & & & & $x$ & & & $x$ & & $x$ & & & & & $x$ & $x$ & $x$ & & $x$ & $x$ & $X$ & & $X$ & 27 \\
\hline$X$ & $x$ & & $x$ & $x$ & $x$ & $x$ & & & & & $x$ & $x$ & $x$ & $x$ & & $x$ & & & $x$ & & $x$ & $x$ & $x$ & $x$ & & $x$ & $x$ & & & & & $x$ & & 27 \\
\hline & & $x$ & & & & & $x$ & $x$ & $x$ & & & & & & $x$ & & $x$ & $x$ & & $x$ & & & & & $x$ & & & $x$ & $x$ & $x$ & $x$ & & $x$ & 27 \\
\hline$x$ & $x$ & & $x$ & $x$ & $x$ & $x$ & $x$ & & & & $x$ & $x$ & $x$ & $x$ & & $x$ & & & $x$ & & $x$ & $x$ & $x$ & $x$ & & $x$ & $x$ & & & & & $x$ & & 28 \\
\hline & & $x$ & & & & & & $x$ & $x$ & $x$ & & & & & $x$ & & $x$ & $x$ & & $x$ & & & & & $x$ & & & $x$ & $x$ & $x$ & $x$ & & & 25 \\
\hline$x$ & $x$ & $x$ & $x$ & $x$ & $x$ & $x$ & $x$ & $x$ & & & $x$ & $x$ & $x$ & $x$ & & $x$ & $x$ & $x$ & $x$ & $x$ & $x$ & $x$ & $x$ & $x$ & & & & $x$ & & & & $x$ & $x$ & 36 \\
\hline & & $x$ & & & & & & $x$ & $x$ & $x$ & & & & & $x$ & & & $x$ & & & & & & & $x$ & $x$ & $x$ & $x$ & $x$ & $x$ & $x$ & & & 23 \\
\hline$x$ & $x$ & $x$ & & $x$ & $x$ & $x$ & & $x$ & & & $x$ & $x$ & & $x$ & & $x$ & & & $x$ & & $x$ & $x$ & $x$ & $x$ & & & & $x$ & & & & $x$ & & 29 \\
\hline & & $x$ & $x$ & & & & & $x$ & $x$ & $x$ & & & $x$ & & $x$ & & & & & $\mathrm{X}$ & & & & & $x$ & $x$ & $\mathrm{X}$ & $x$ & $x$ & $x$ & $x$ & & & 26 \\
\hline
\end{tabular}

Tabela 8 (Continuação). Ficha de análise da dimensão percepção . Elaborada pela autora em 2014. 


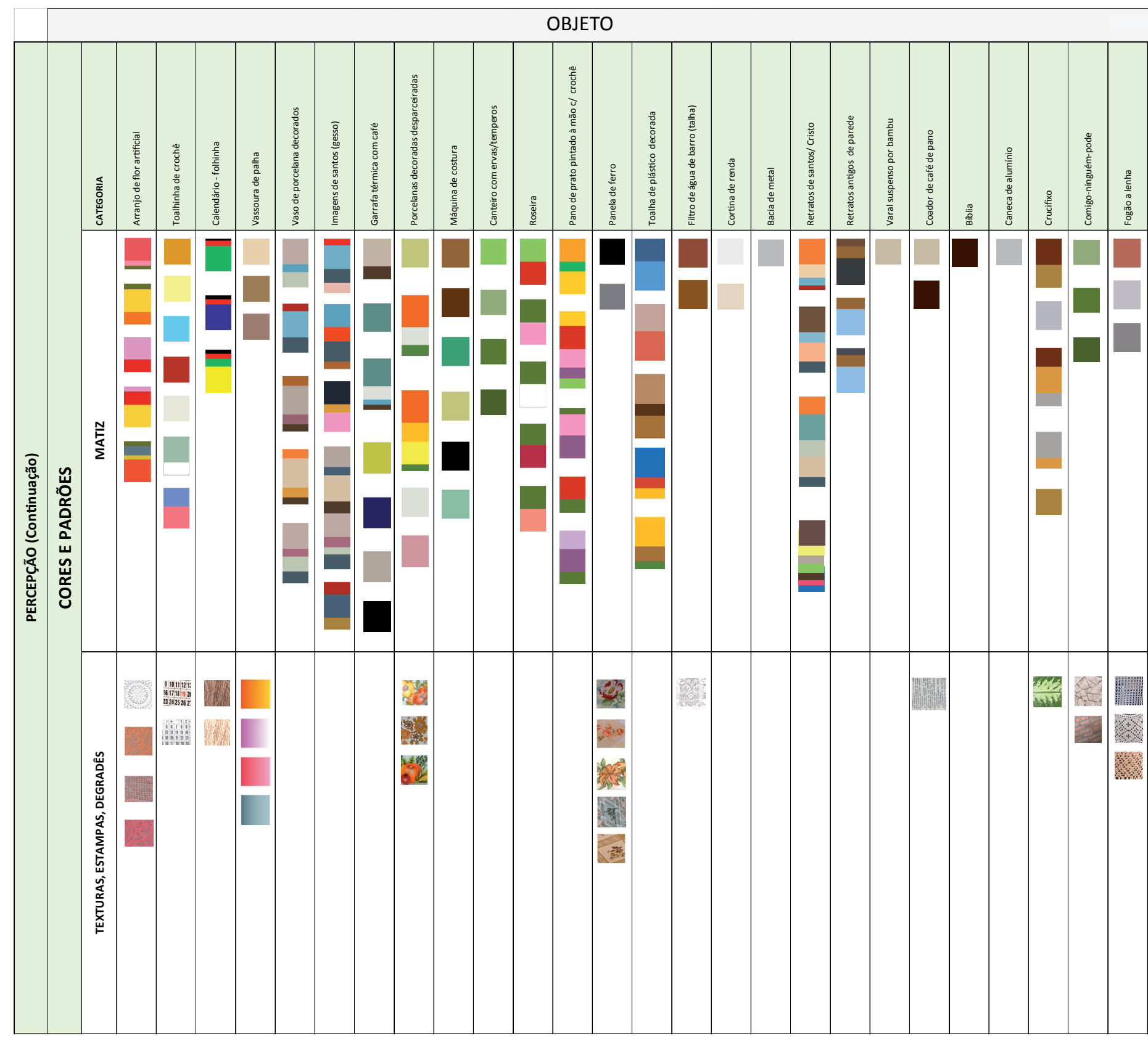

Tabela 9. Ficha de análise da dimensão percepção, para as categorias cores e padrões . Elaborada pela autora em 2014. 


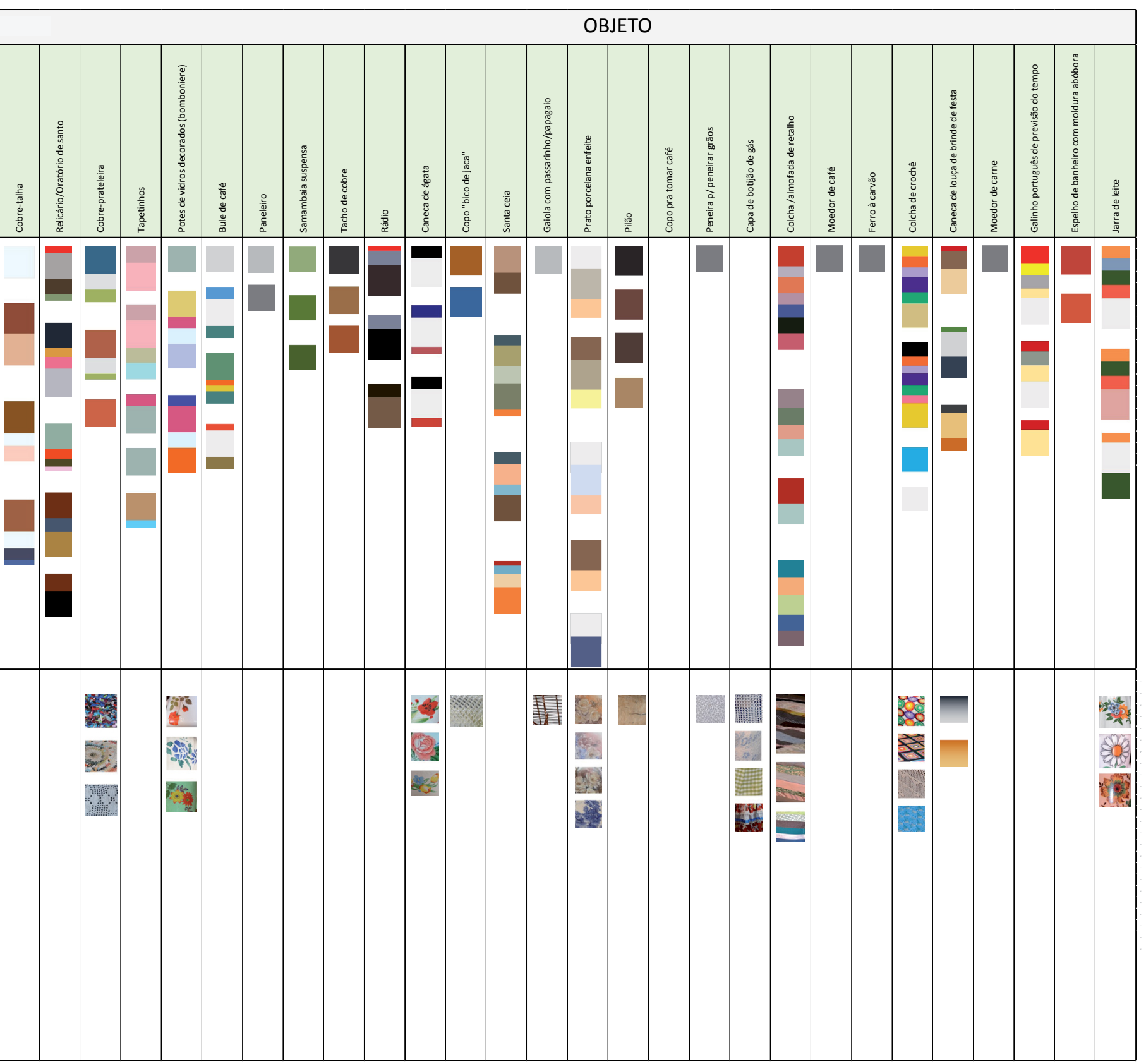

Tabela 9 (Continuação). Ficha de análise da dimensão percepção, para as categorias cores e padrões . Elaborada pela autora em 2014. 


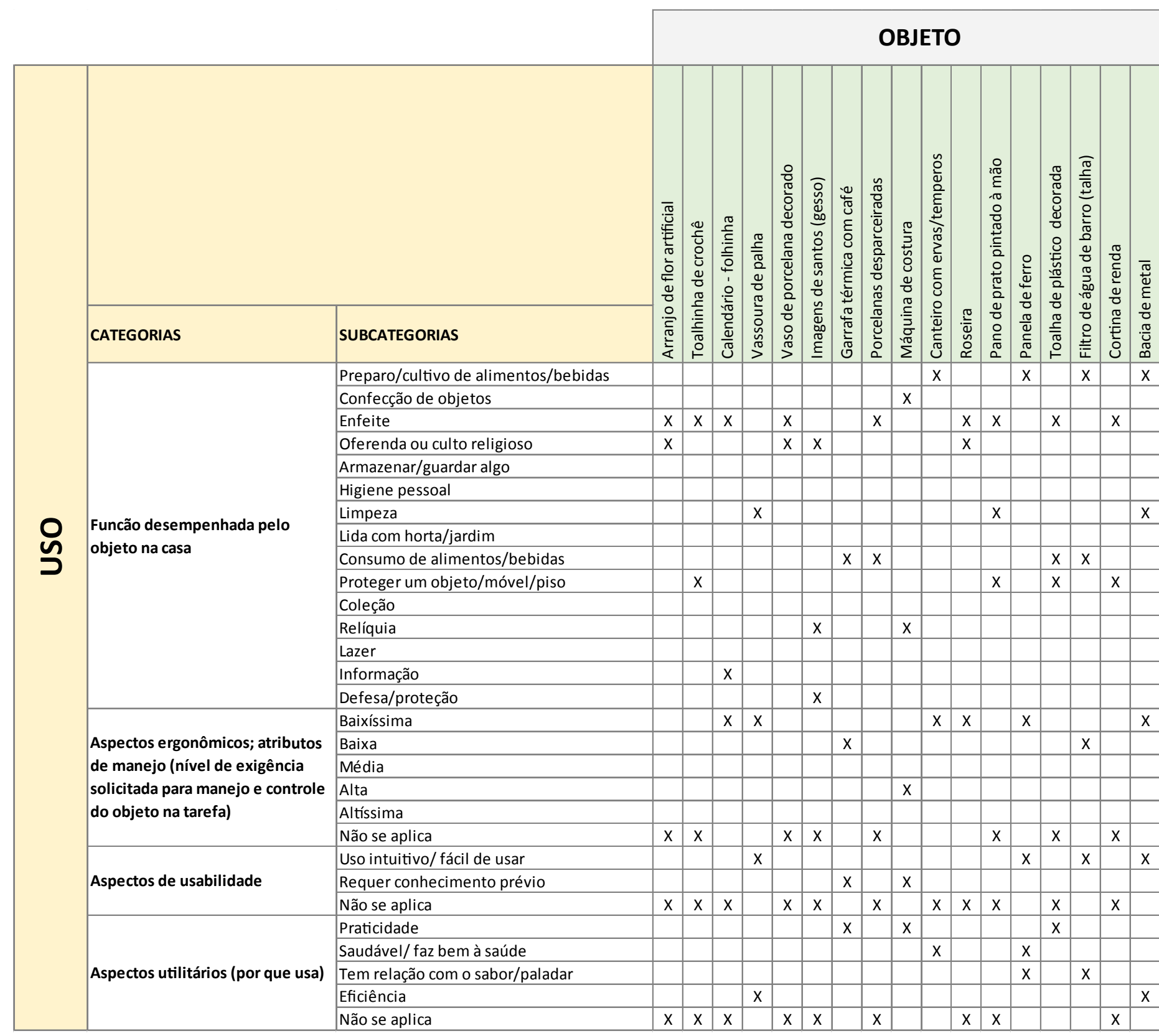

Tabela 10. Ficha de análise da dimensão uso. Elaborada pela autora em 2014. 


\section{OBJETO}

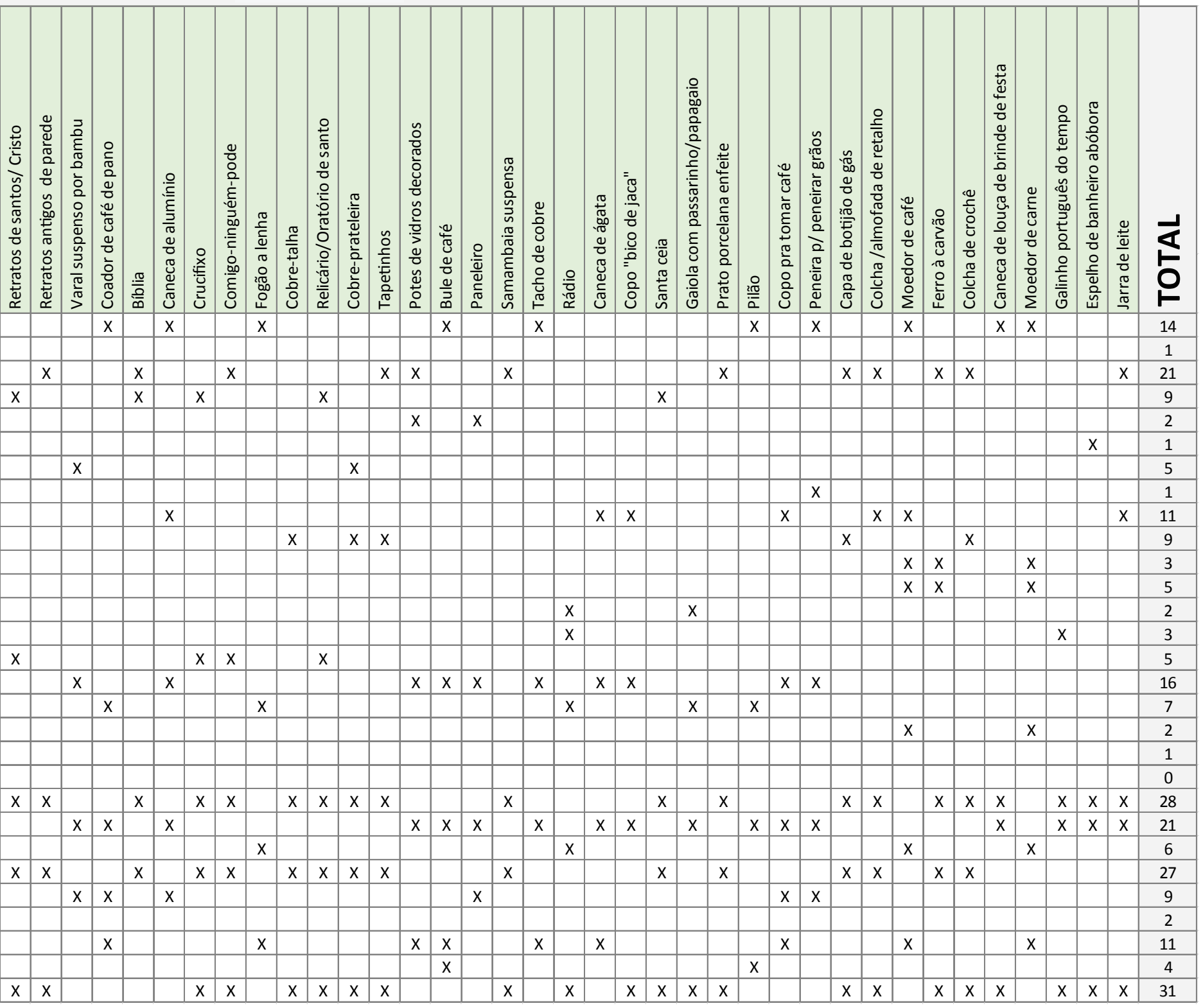

Tabela 10 (Continuação). Ficha de análise da dimensão uso. Elaborada pela autora em 2014. 


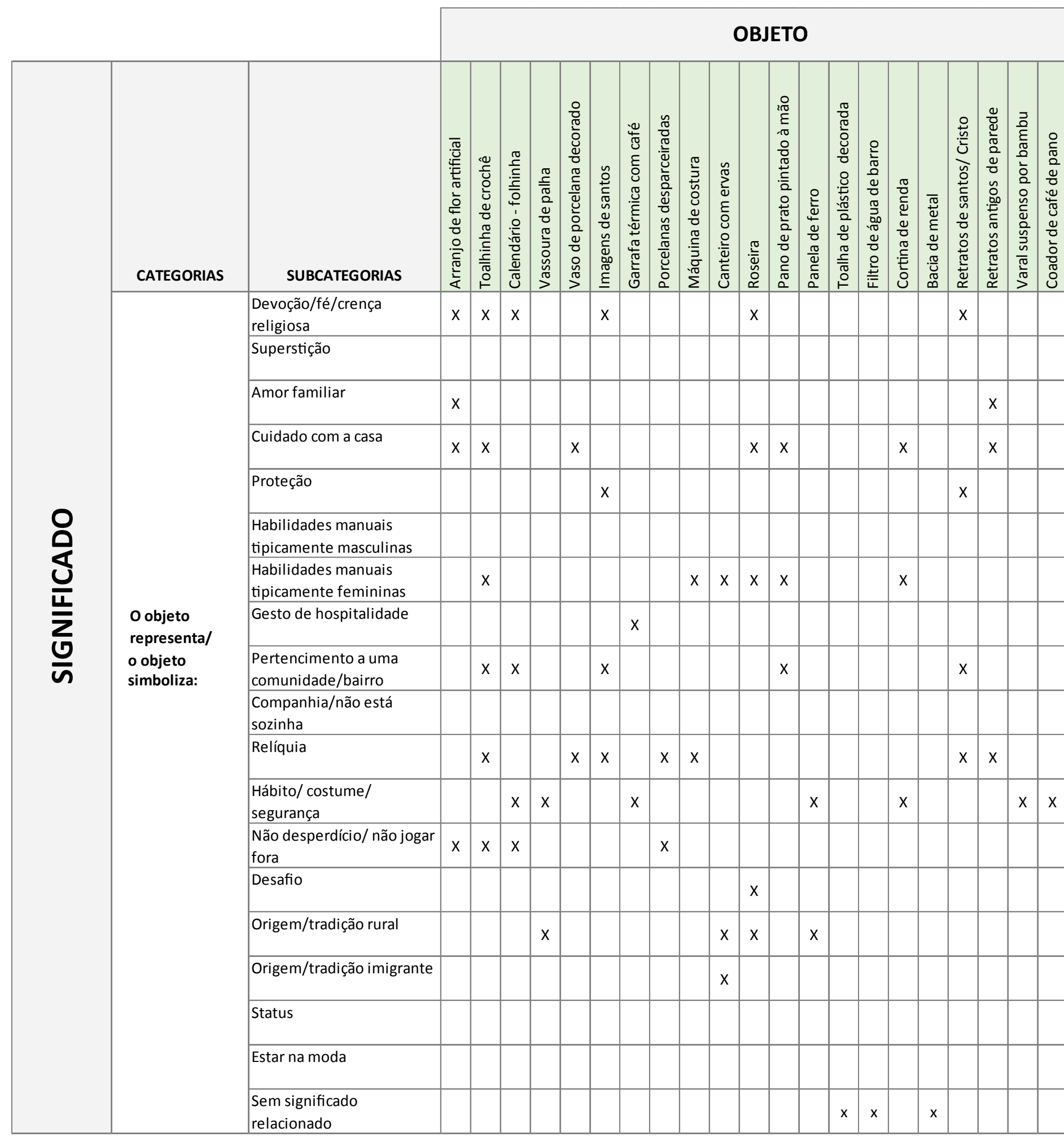




\begin{tabular}{|c|c|c|c|c|c|c|c|c|c|c|c|c|c|c|c|c|c|c|c|c|c|c|c|c|c|c|c|c|c|c|c|c|c|}
\hline & & & & & & & & & & & & & & & OB & JE & TO & & & & & & & & & & & & & & & & \\
\hline$\frac{.00}{\frac{0}{0}}$ & 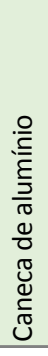 & 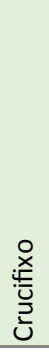 & 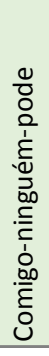 & 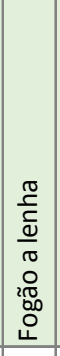 & 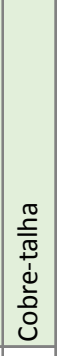 & 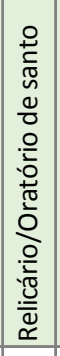 & 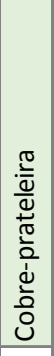 & 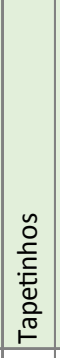 & 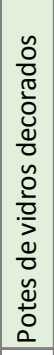 & $\begin{array}{l}\frac{0}{4} \\
\frac{\pi}{0} \\
0 \\
0 \\
\frac{0}{J} \\
\frac{0}{5} \\
\end{array}$ & 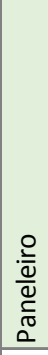 & 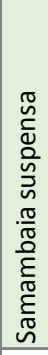 & 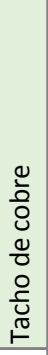 & 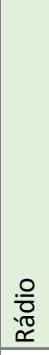 & 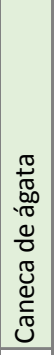 & 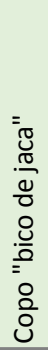 & 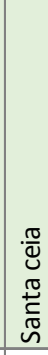 & 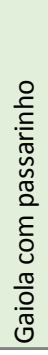 & 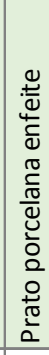 & $\frac{20}{20}$ & $\begin{array}{l}\frac{\pi}{\pi} \\
\frac{\pi}{0} \\
\frac{1}{\sigma} \\
\frac{1}{0} \\
0 \\
0 \\
\frac{\pi}{2} \\
0 \\
0 \\
0 \\
0\end{array}$ & 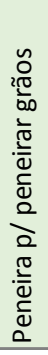 & 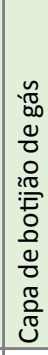 & 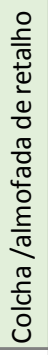 & 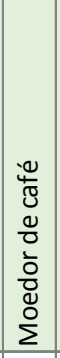 & $\begin{array}{l}0 \\
2 \pi \\
2 \\
2 \\
0 \\
0 \\
-\pi \\
0 \\
0 \\
0 \\
0 \\
4 \\
\end{array}$ & 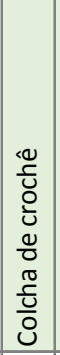 & 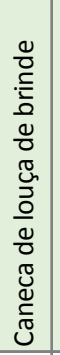 & 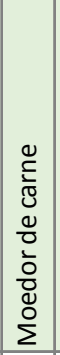 & 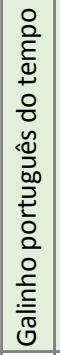 & 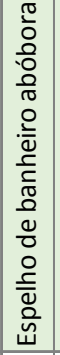 & 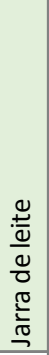 & $\frac{\overrightarrow{1}}{\stackrel{5}{\circ}}$ \\
\hline$x$ & & $x$ & & & & $x$ & & & & & & & & $x$ & & & $x$ & & & & & & & & & & & & & & & & 11 \\
\hline & & & $x$ & & & & & & & & & & & & & & & & & & & & & & & & & & & $x$ & & & 2 \\
\hline & & & & & & & & & $x$ & & & & & & & & & & & & & & & & & & & & & & & & 3 \\
\hline & & & & & $x$ & & $x$ & $x$ & & & $x$ & $x$ & & & & & & & $x$ & & & & $x$ & $x$ & & & $x$ & & & & & & 16 \\
\hline & & & $x$ & & & $x$ & & & & & & & & & & & $x$ & & & & & & & & & & & & & & & & 5 \\
\hline & & & & & & & & & & & & & $x$ & & & & & $x$ & & & & & & & $x$ & & & & $x$ & & & & 4 \\
\hline & & & & & $x$ & & $x$ & $x$ & & & & & $x$ & & & & & & & & & & $x$ & $x$ & $x$ & & $x$ & & & & & & 14 \\
\hline & & & & & & & & & $x$ & & & & & & & $x$ & & & & & & & & & & & & & & & & & 3 \\
\hline$x$ & & & & & & & & & $x$ & & & & & & & & & & & & & & & & & & & $x$ & $x$ & & & & 9 \\
\hline & & & & & & & & & & & & & & $X$ & & & & & & & & & & & & & & & & & & & 1 \\
\hline$x$ & & $x$ & & & & $x$ & & & & & & & & & & $x$ & & & $x$ & & & & & & & $x$ & & & $x$ & & & $x$ & 15 \\
\hline & & & $x$ & $x$ & & & & & & & & $x$ & & & $x$ & & & & & & $x$ & & & & & & & & & & & & 12 \\
\hline & & & & & & & & $x$ & & & & & & & & & & & & & & & & $x$ & & & $x$ & & $x$ & & & $x$ & 9 \\
\hline & & & & & & & & & & & & & & & & & & $x$ & & & & & & & & & $x$ & & & & & & 3 \\
\hline & & & $x$ & $x$ & & & & & & & & & $x$ & & & & & $x$ & & & & & & & $x$ & & & & $x$ & & & & 10 \\
\hline & & & & & & & & & & & & & & & & & & & & & & & & & $x$ & & & & $x$ & $x$ & & & 4 \\
\hline & & & & & & & & & & & & & & & & $x$ & & & $x$ & & & & & & & & & & & & & & 2 \\
\hline & & & & & & & & & & & & & & & & & & & & & & & & & & & & & & & & & 0 \\
\hline & $x$ & & & & & & & & & $x$ & & & & & & & & & & $x$ & & $x$ & & & & & & & & & $x$ & & 8 \\
\hline
\end{tabular}




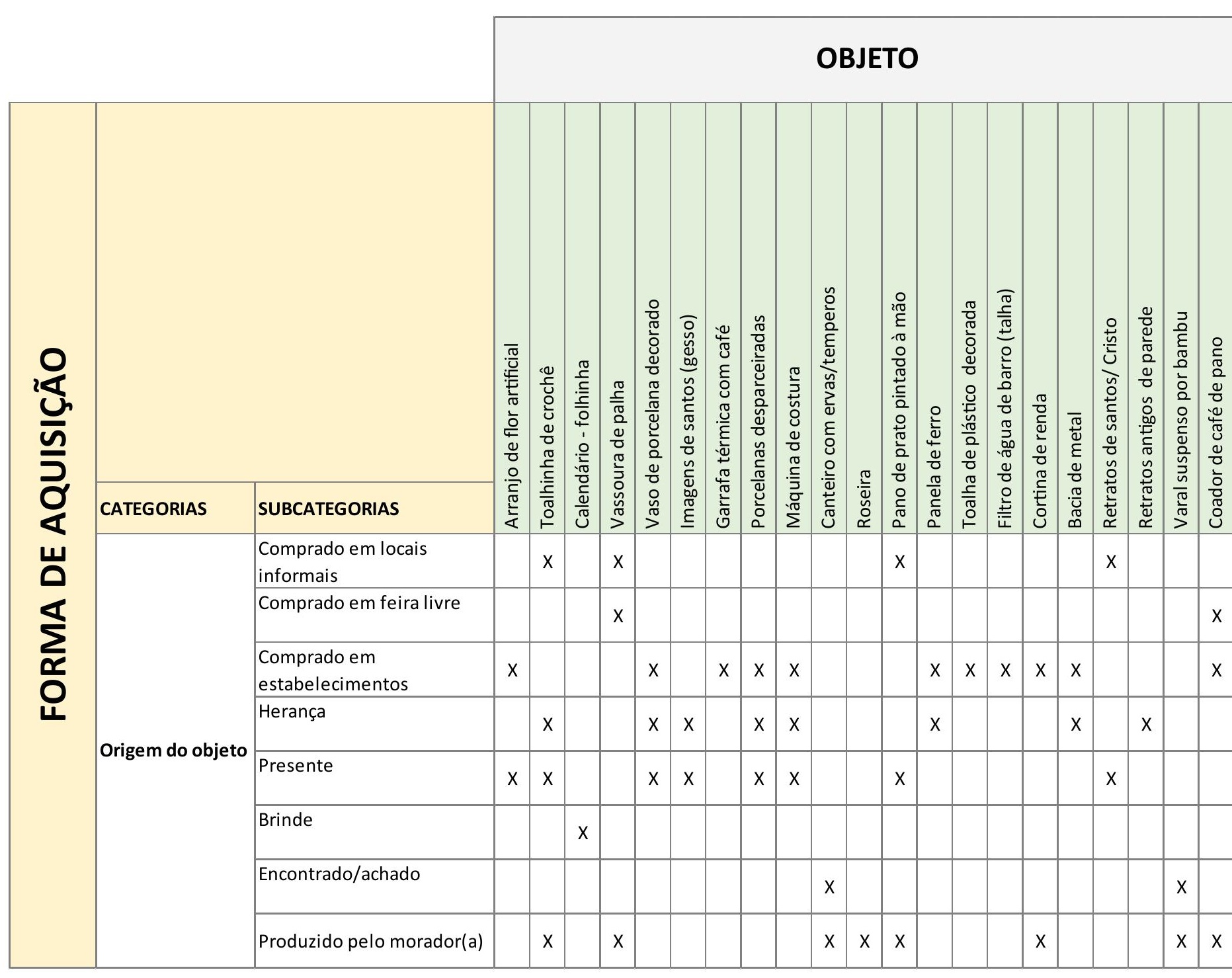

Tabela 12. Ficha de análise da forma de aquisição. Elaborada pela autora em 2014. 


\begin{tabular}{|l|l|l|l|l|l|l|l|l|l|l|l|l|l|l|l|l|l|l|l|l|l|l|}
\hline \multicolumn{2}{|c|}{ OBJETO } \\
\hline
\end{tabular}

Tabela 12 (Continuação). Ficha de análise da forma de aquisição. Elaborada pela autora em 2014 


\section{Confrontação dos artefatos com as memórias}

De posse de imagens fotográficas dos artefatos notáveis encontrados na pesquisa de campo, voltamos aos adultos respondentes, cujas memórias de infância constituíram a base para a pesquisa, a fim de confrontar as imagens daqueles artefatos capturadas na pesquisa de campo com suas lembranças. $O$ resultado desta atividade fala muito sobre a relação dos indivíduos com suas origens e sua identidade, bem como sobre o ato de relembrar. Os achados desta etapa estão detalhados no Capítulo 3, "Análise do confronto dos artefatos com as memórias". 
Capítulo 3
Resultados Capítulo 3
Resultados

\section{Capítulo 3
Resultados \\ Capítulo 3
Resultados

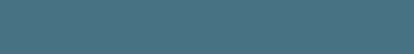

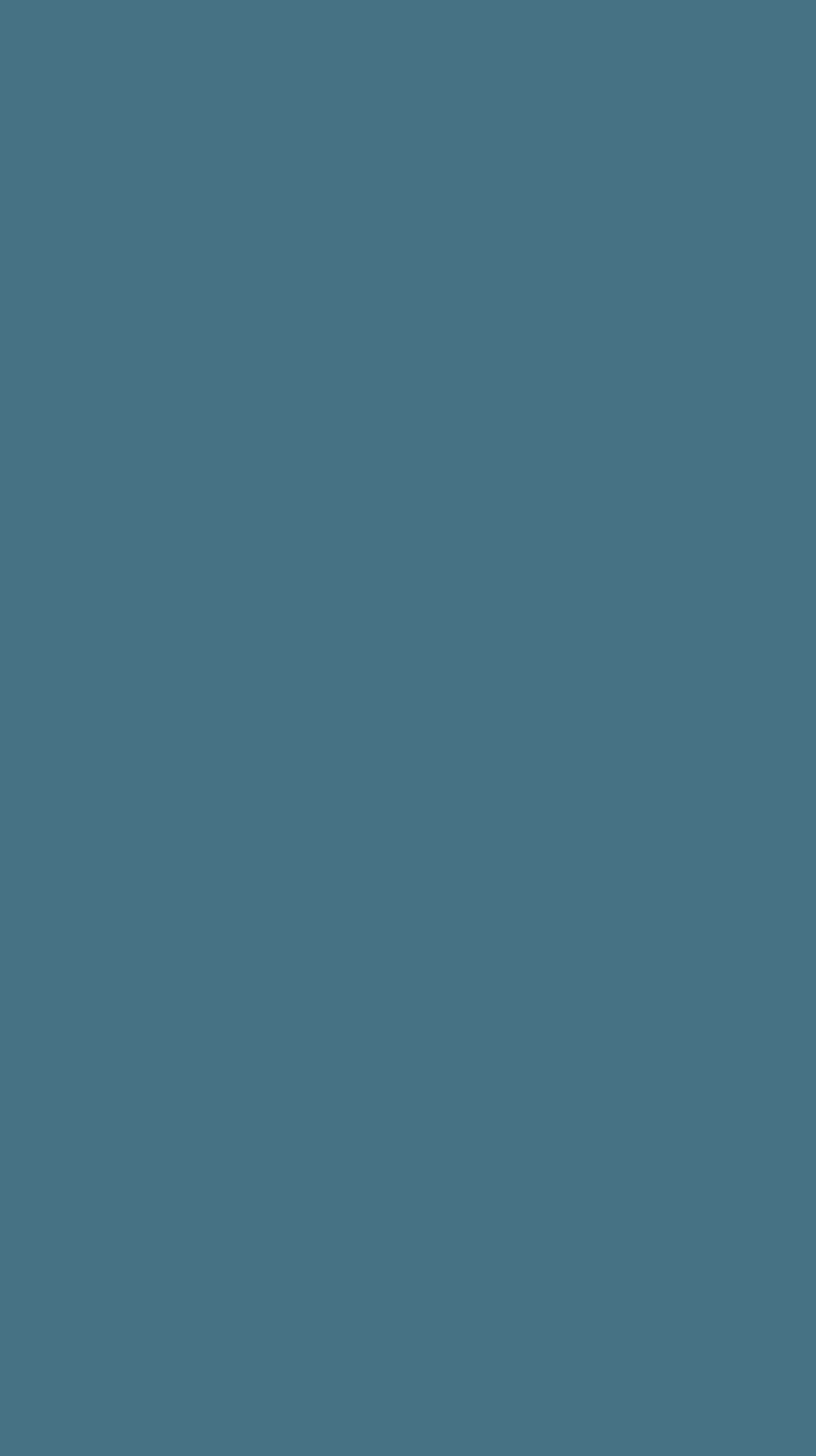


Este capítulo corresponde às interpretações das análises realizadas anteriormente, gerando efetivamente o que se poderá chamar de resultados da pesquisa.

Feitas as análises de acordo com as fichas propostas, pode-se observar certos padrões de ocorrências como se demonstra a seguir. Este processo não tratou simplesmente de levantar estatísticas sobre os artefatos; os números aqui levantados serviram de guia para a investigação dos aspectos que caracterizam os objetos, mas também interessou-nos o detalhe único, as práticas individuais e suas variáveis.

Inclui-se, ainda, o resultado obtido ao confrontarmos as imagens dos artefatos notáveis com as memórias dos respondentes, cujas lembranças deram origem à lista de objetos a serem pesquisados em campo.

\section{Análise da dimensão relativa à percepção}

Os resultados obtidos na compilação dos dados das tabelas em suas categorias permitiram-nos fazer algumas considerações. Em relação aos atributos físicos dos objetos estudados, a primeira constatação foi a respeito das matérias-primas de que são feitos (Gráfico 3).

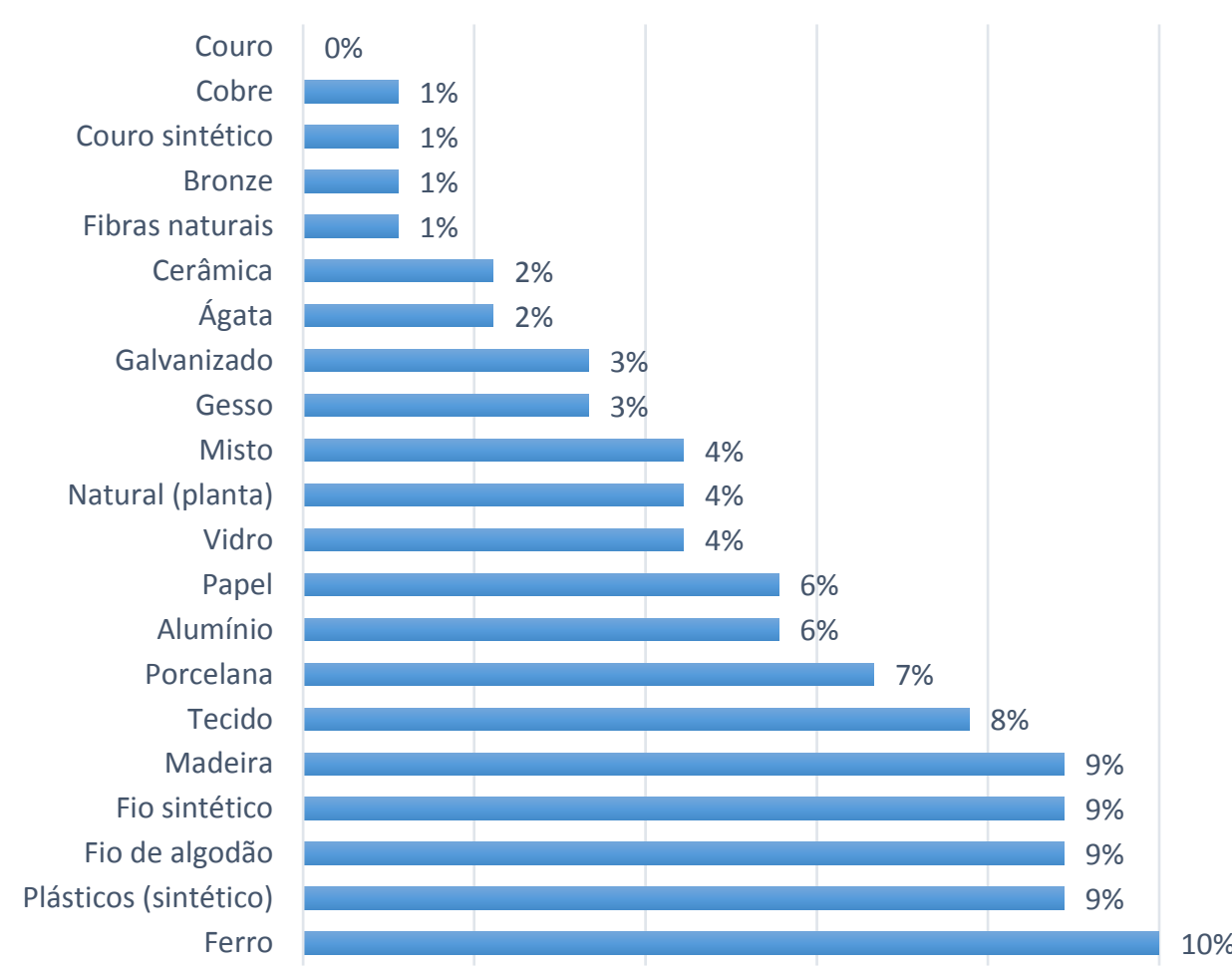

Gráfico 3. Matéria-prima dos artefatos. Elaborado pela autora, 2015.

Pode-se observar a forte presença do ferro, juntamente com os plásticos e a madeira. Isto ilustra uma possível herança da cultura material de seus antepassados, quando este metal aparecia como principal matéria-prima de bens duráveis. Também se observou a forte presença de fios, tanto sintéticos quanto naturais, matéria-prima de todos os objetos confeccionados em crochê encontrados nas residências. 
Outro dado interessante diz respeito à presença de vários artefatos feitos de matéria-prima reutilizada, como é o caso das colchas e almofadas de retalhos de tecidos, dos panos de prato feitos a partir da reutilização de sacos de algodão alvejados ou ainda dos vidros de conserva transformados em potes para balas e outras guloseimas com tampas decoradas à mão (com apliques de crochê, biscuit e tecidos).

As análises de aspectos de composição formal, à exceção do par de contrastes equilíbrio/ instabilidade, mostram valores próximos ou iguais nos pares, como por exemplo, economia/ profusão. (Gráfico 4)

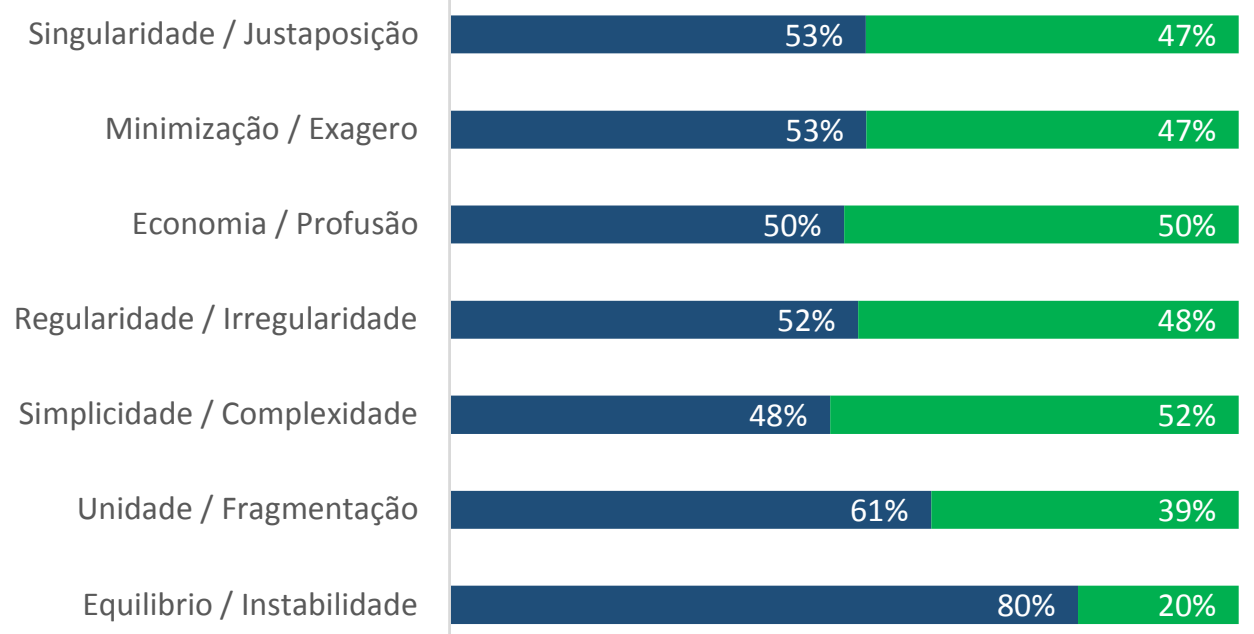

Gráfico 4. Aspectos da composição formal. Elaborado pela autora, 2015.

Estes dados revelam a existência de dois universos formais distintos e equilibrados: de um lado, aparecem os objetos formalmente muito simples, relacionados a atributos como simplicidade, regularidade, economia, minimização, unidade e singularidade. Estes artefatos são essencialmente funcionais e desprovidos de elementos decorativos, como, por exemplo, peneiras, bacias, pilões, vassouras, canecas de ágata e de alumínio (Quadro 2).

Por outro lado, e proporcionalmente, apareceram objetos carregados de informação visual, que se relacionam com atributos como complexidade, instabilidade, irregularidade, profusão, exagero, fragmentação e justaposição. Aqui, enquadram-se artefatos como os arranjos de flores artificiais em vasos de porcelana decorados em tons degradês, cortinas de renda carregadas de pregas e babados, imagens de santos e objetos produzidos pelas moradoras, como potes de balas ou tapetinhos de banheiros pintados à mão (Quadro 3). 


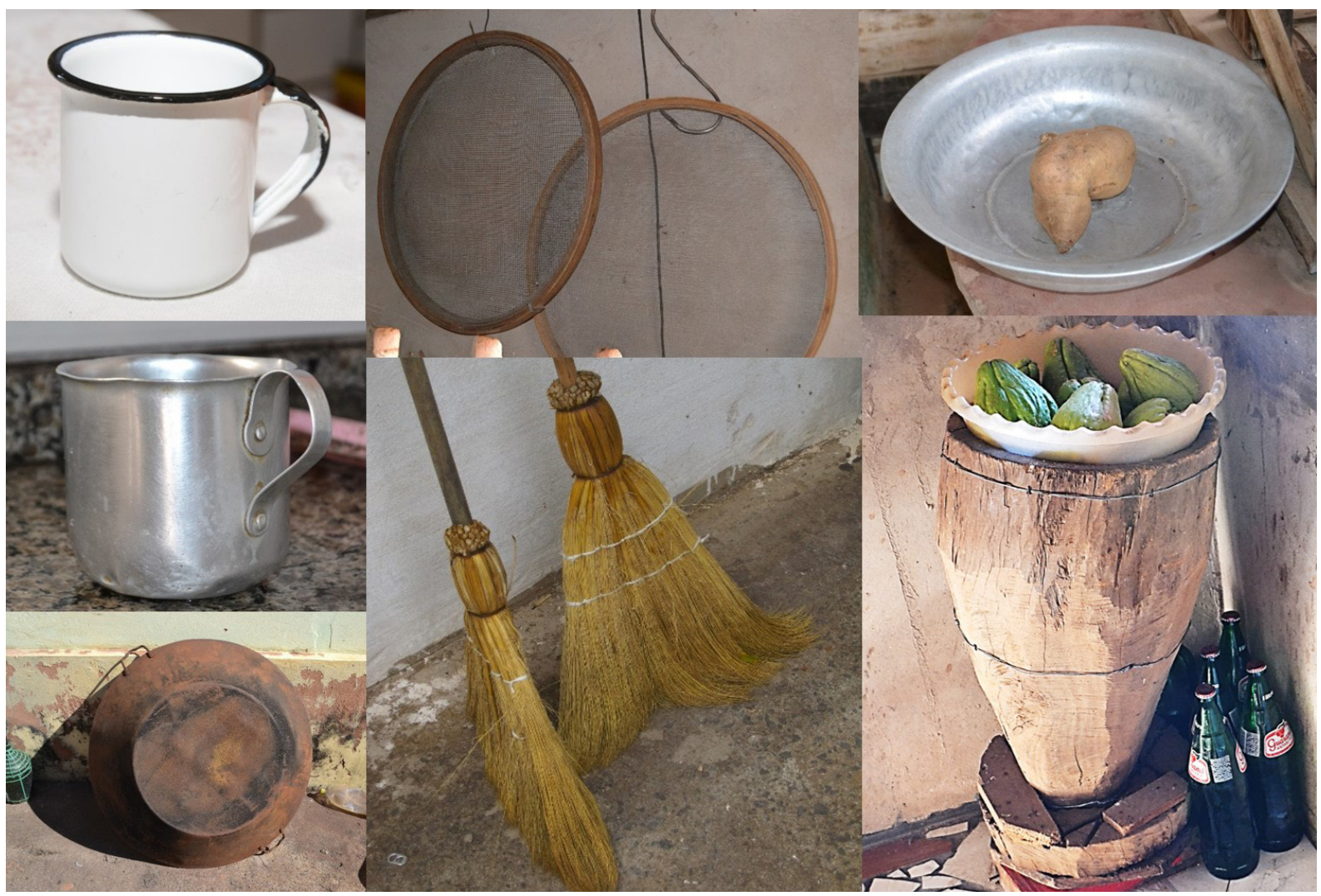

Quadro 2. Artefatos que apresentam simplicidade formal. Registros fotográficos da autora, 2014 (à exceção do pilão, foto: Eliete Soares).

Da esquerda para a direita e de cima para baixo: caneca da ágata, Laranjal Paulista; peneira de grãos, Limeira; bacia de alumínio, Limeira; caneca de alumínio, Botucatu; vassoura de palha, Monte Aprazível; pilão de madeira, Botucatu; tacho de cobre, Monte Aprazível.

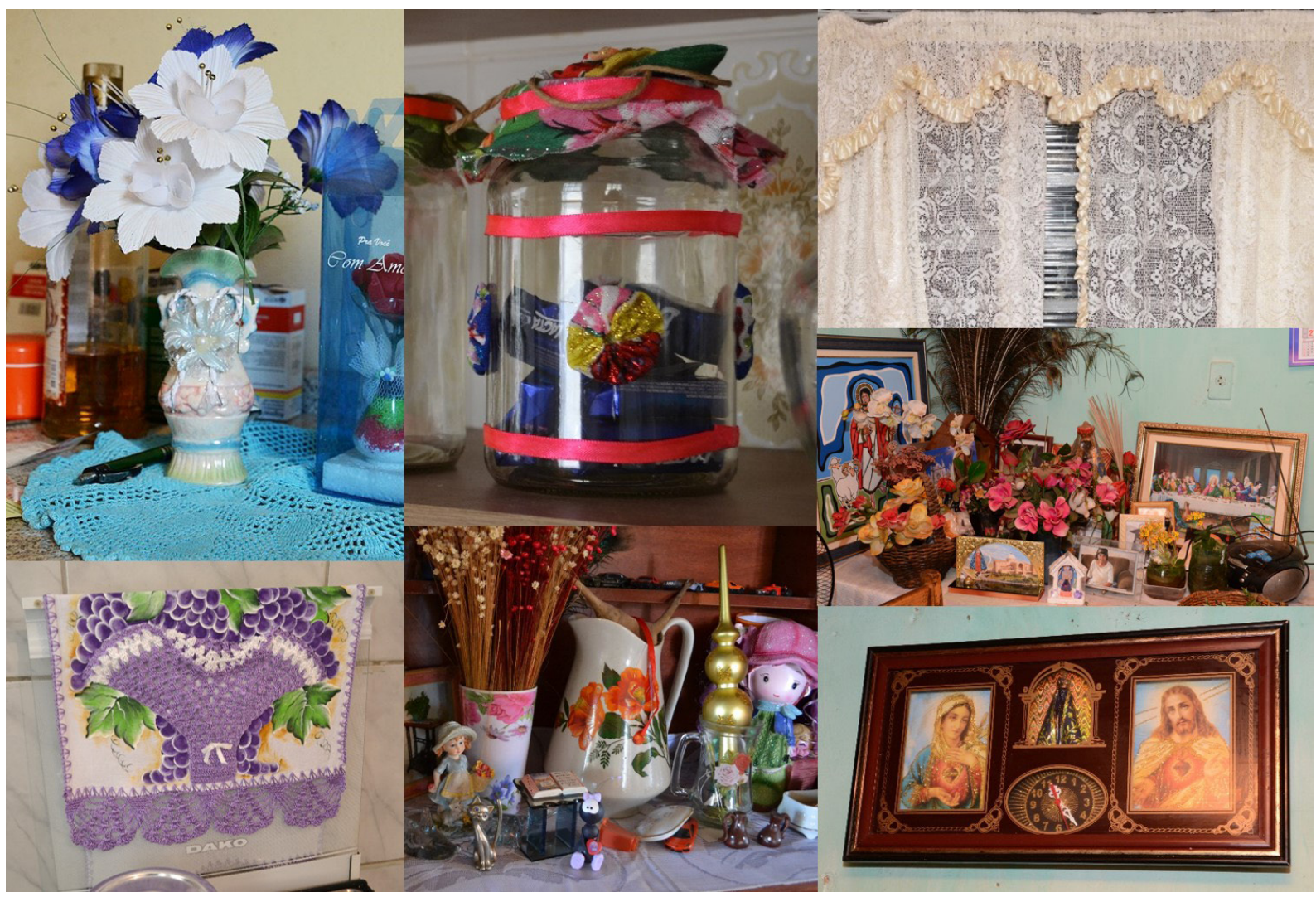

Quadro 3. Artefatos que apresentam complexidade formal. Registros fotográficos da autora (à exceção do quadro de madeira, foto: Eliete Soares), 2014. Da esquerda para a direita e de cima para baixo: vaso de porcelana com flores artificiais sobre toalhinha de crochê, Piracicaba; pote de balas decorado com fitas e apliques, São Luís de Paraitinga; cortina de renda, Rio Claro; pano de prato pintado à mão com apliques de crochê, Piracicaba; vaso com flores secas, jarra de leite e outros bibelôs, Botucatu; flores, enfeites, imagens de santos em pequeno altar, Botucatu; quadro de madeira com imagens de santos e relógio, Botucatu. 
Do ponto de vista cromático, pode-se observar alguns padrões de associação que compõem novamente dois universos distintos, os quais também coabitam lado a lado nas residências, da mesma forma que a simplicidade e a complexidade formais já citadas. Por um lado, pudemos perceber o excesso cromático de tons vibrantes e contrastantes presentes em arranjos florais, altares de santos, tapetinhos e toalhas de plástico estampadas, por exemplo (Quadro 4). Por outro, notou-se uma forte presença de tons esmaecidos, cores que já foram vivas mas que, devido ao tempo de exposição dos objetos à luz, acabaram dando origem a uma paleta mais discreta, de tons amarelados, como os retratos de parede ou alguns pequenos tapetes e almofadas, desbotados pelo sol e encardidos pelo tempo de uso (Quadro 5).

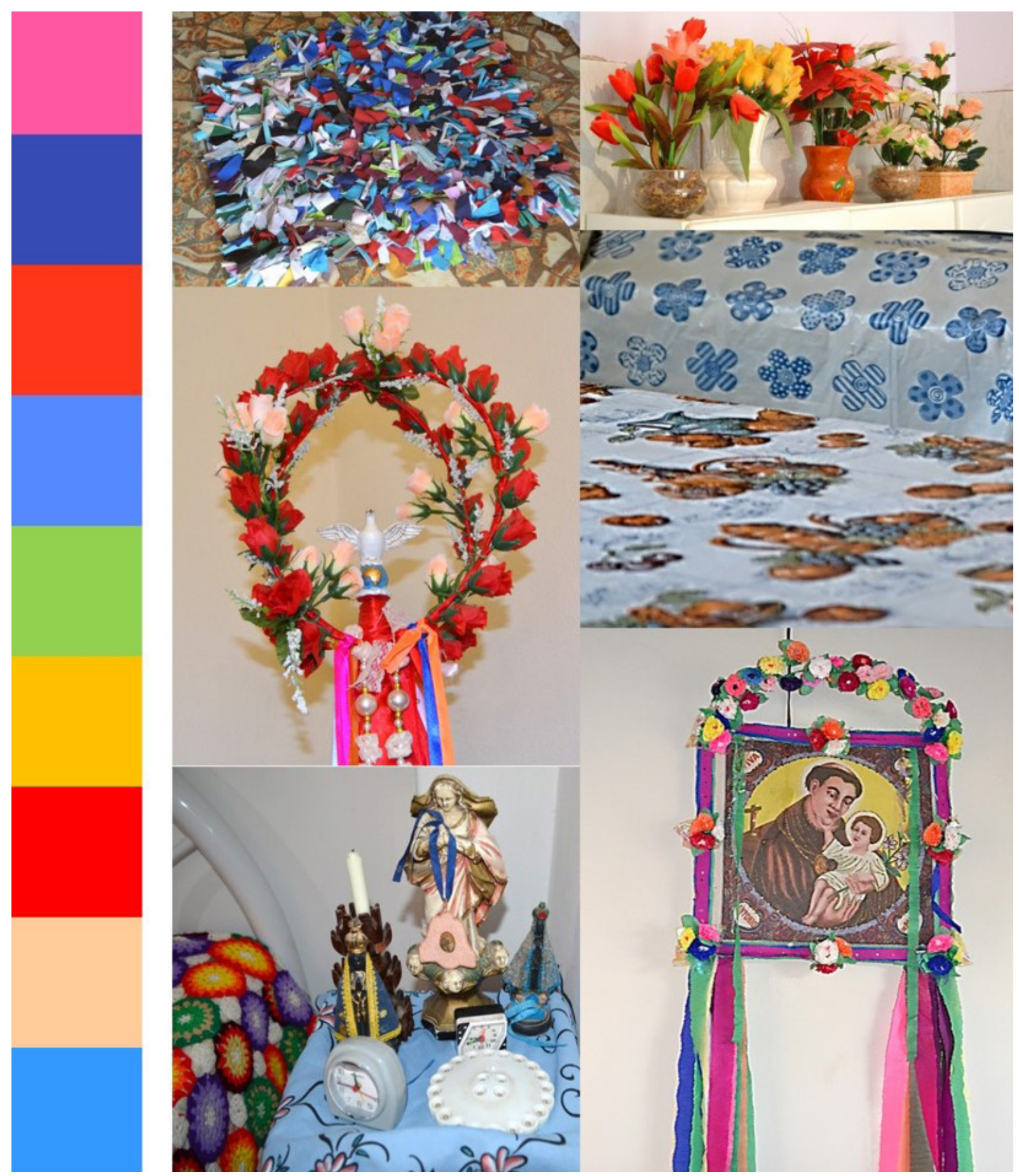

Quadro 4. Paleta de tons vibrantes e contrastantes presentes em determinados artefatos. Registros fotográficos da autora, 2014.

Da esquerda para a direita e de cima para baixo: paleta de cores extraídas das imagens (produzida pela autora); tapete de retalhos, Laranjal Paulista; vasos com flores artificiais, Piracicaba; estandarte do Divino Espírito Santo; São Luís do Paraitinga; toalhas de plástico, Laranjal Paulista; colcha de crochê e imagens de santos sobre toalha bordada, Piracicaba; relicário de Santo Antônio, Monte Aprazível. 


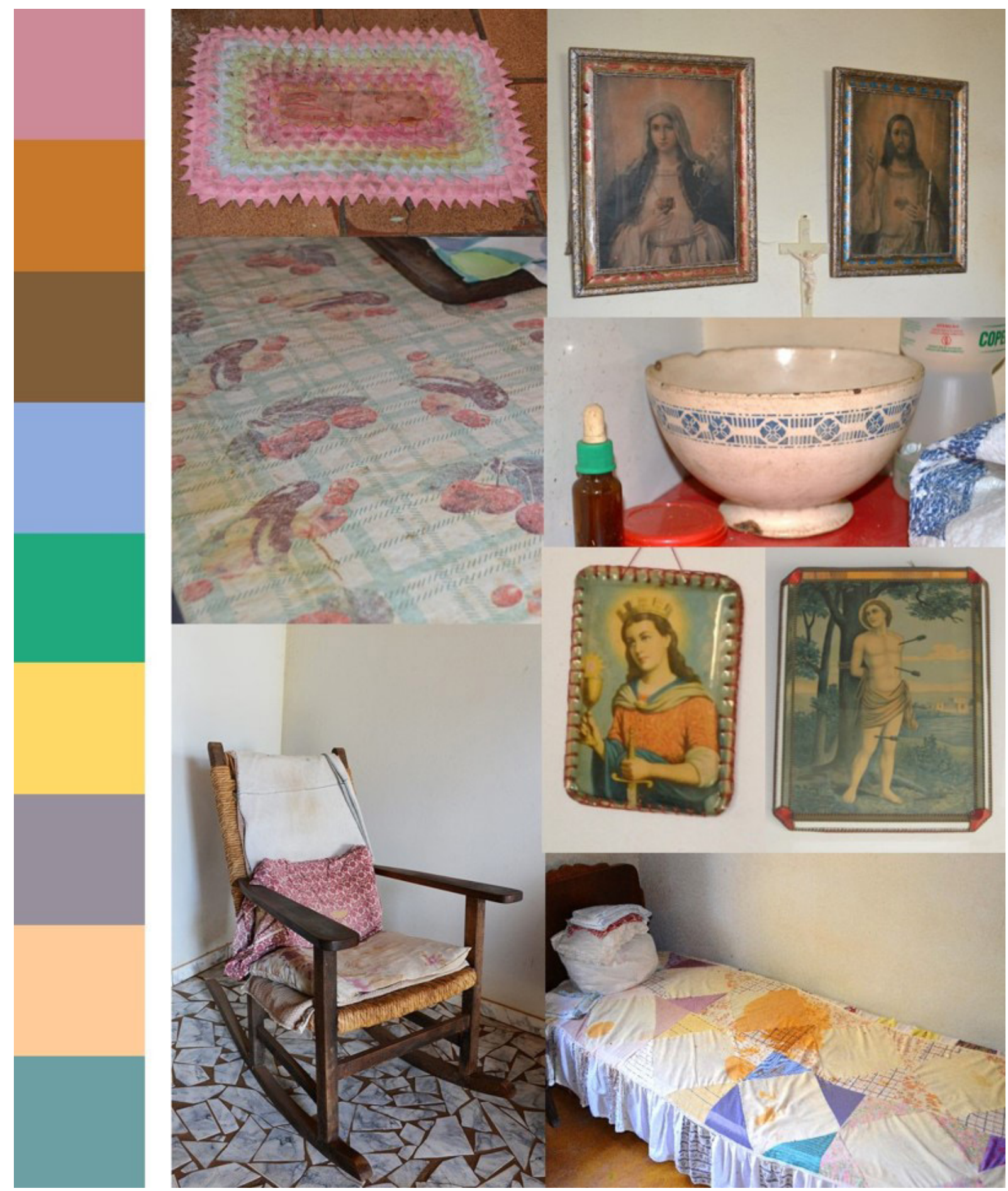

Quadro 5. Paleta de tons esmaecidos, cores desbotadas pelo tempo presentes em determinados artefatos. Registros fotográficos da autora, 2014 (à exceção da cadeira de balanço, foto: Eliete Soares).

Da esquerda para a direita e de cima para baixo: paleta de cores extraídas das imagens (produzida pela autora); tapetinho de retalhos, Laranjal Paulista; imagens de santos, Laranjal Paulista; toalha de plástico, Laranjal Paulista; tigela de porcelana, Limeira; cadeira de balanço com almofada de retalho, Laranjal Paulista; imagem de Santa Bárbara, Piracicaba; imagem de São Sebastião, Piracicaba; colcha de retalho, Botucatu. 


\section{Análise da dimensão relativa ao uso}

A primeira subcategoria diz respeito à função do artefato na casa, para que ele é utilizado (Gráfico 5).

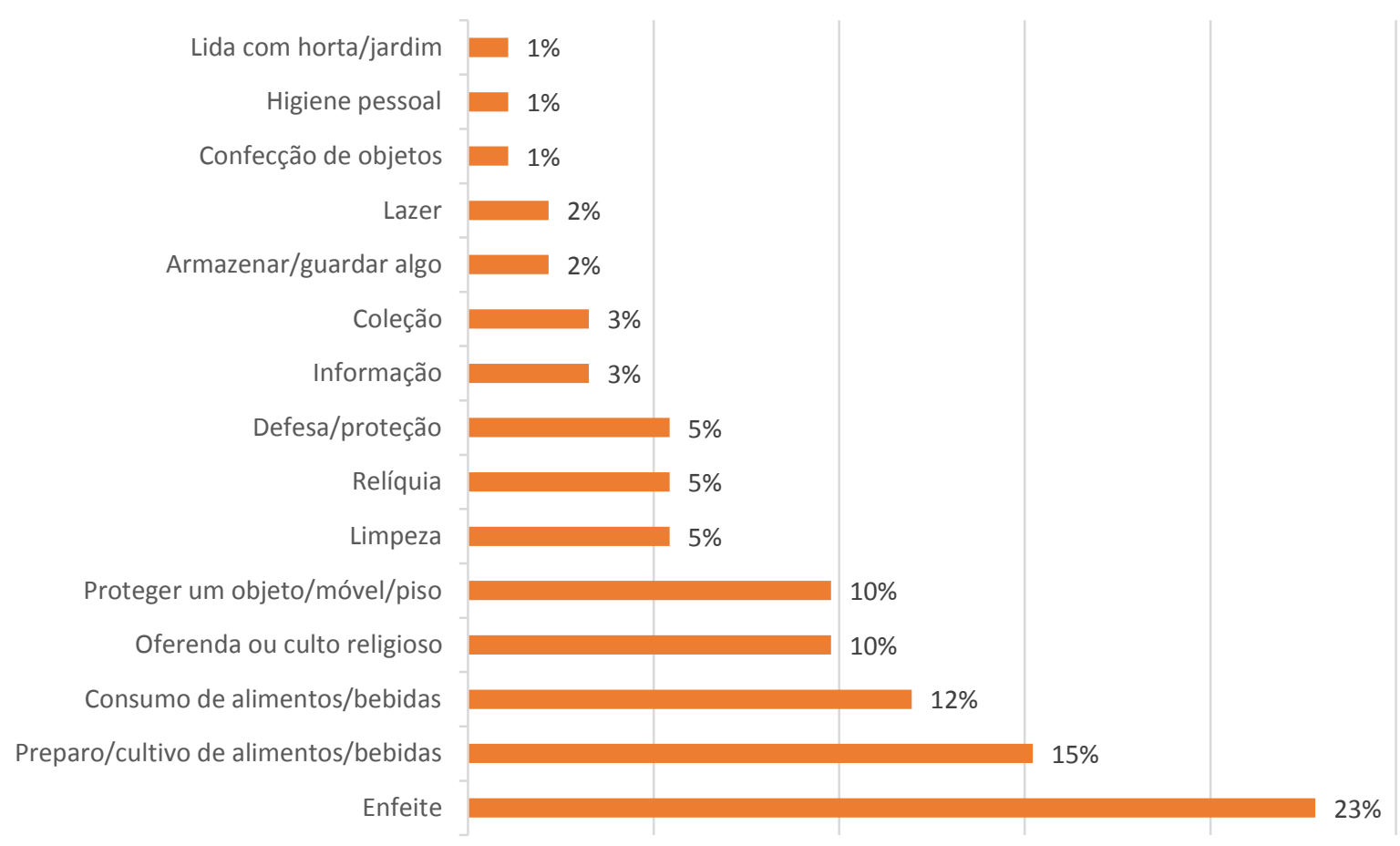

Gráfico 5. Função do artefato na casa. Elaborado pela autora, 2015

Percebe-se que a maioria tem função de enfeite, o que não significa atuar exclusivamente como tal, mas este número expressivo mostra-nos que a preocupação estética traduzida em enfeitar a casa é um valor entre a população estudada.

Outro dado interessante diz respeito a duas subcategorias: preparo/cultivo de alimentos/bebidas e consumo de alimentos/bebidas, que juntas somam $27 \%$ das ocorrências. Estas, respectivamente segunda e terceira funções mais presentes, indicaram a importância destes hábitos dentre a população estudada, para quem preparar a comida ou a bebida é uma atividade cotidiana e rotineira.

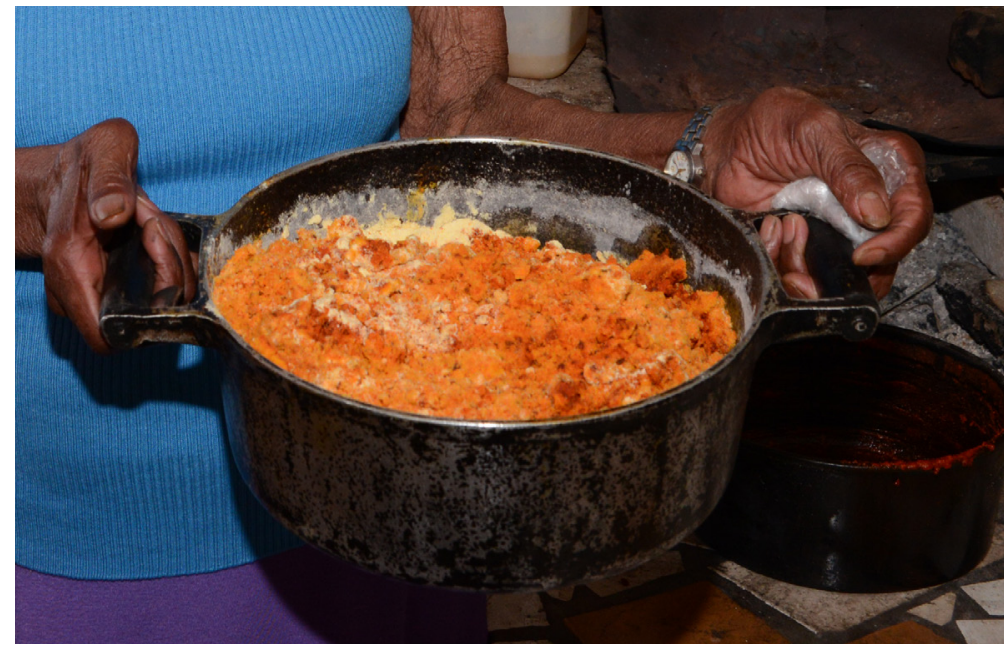

Figura 29. Panela de ferro para preparo diário de alimentos. Botucatu. Foto: Eliete Soares, 2014.
Das vinte famílias entrevistadas, em apenas uma não se prepara a refeição na hora do almoço todos os dias.

Aqui, enquadraram-se artefatos desde a panela de ferro (Figura 29), utilizada diariamente, até o pilão, objeto rústico feito de madeira maciça entalhada, utilizado para triturar certos tipos de grãos no preparo de alimentos sazonais. 


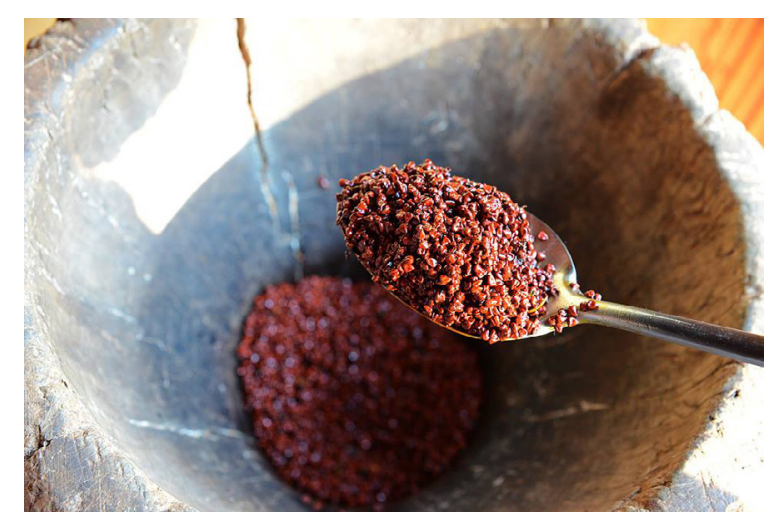

Figura 30. Pilão com semente de urucum para preparo do Colorau. Laranjal Paulista. Foto: Eliete Soares, 2014.

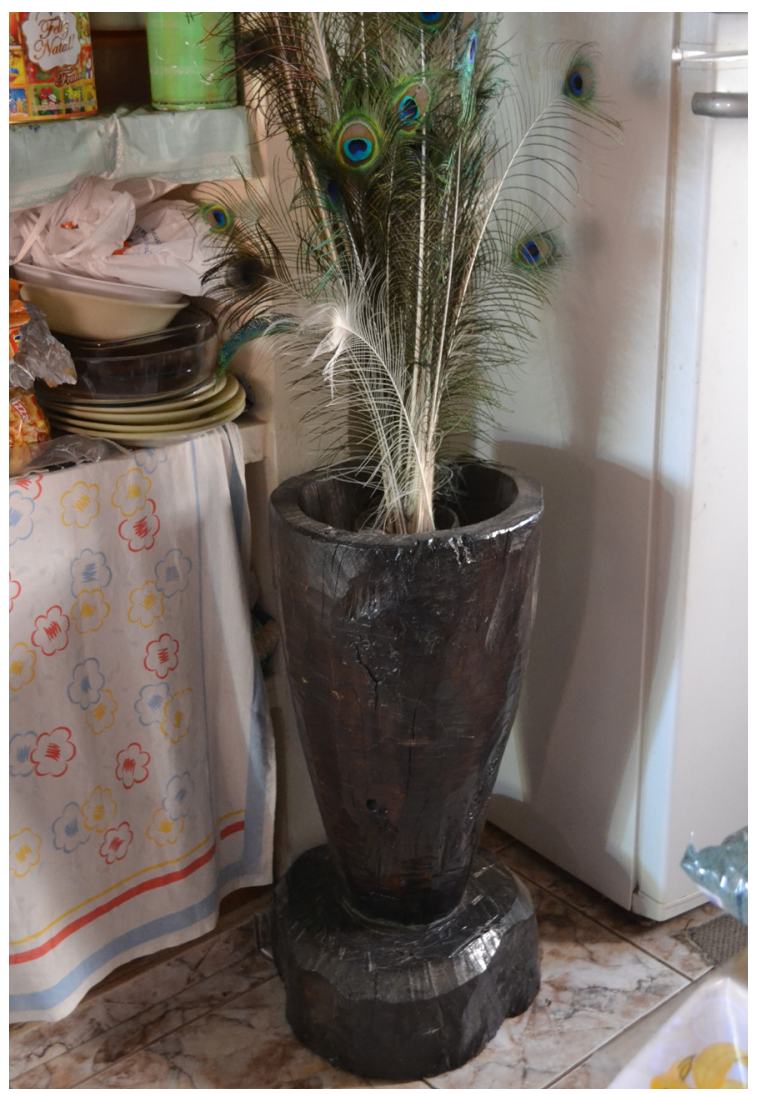

Figura 31. Pilão utilizado como enfeite por não estar em uso. Botucatu. Foto: Eliete Soares, 2014
Durante as visitas a campo no mês de julho, pudemos observar, em duas ocasiões, o uso do pilão para triturar a semente do urucum (Figura 30) a fim de extrair seu sumo vermelho para o preparo do colorau, condimento utilizado para temperar carnes e outros pratos por sua capacidade de realçar a cor dos alimentos. Mesmo pouco utilizado, o pilão não é dispensado. Em alguns casos, enquanto não está em uso, serve de enfeite e se torna um arranjo de penas de pavão, por exemplo (Figura 31). Em outros, faz as vezes de mesinha lateral, tendo sua parte superior côncava utilizada para conter objetos (Figura 32).

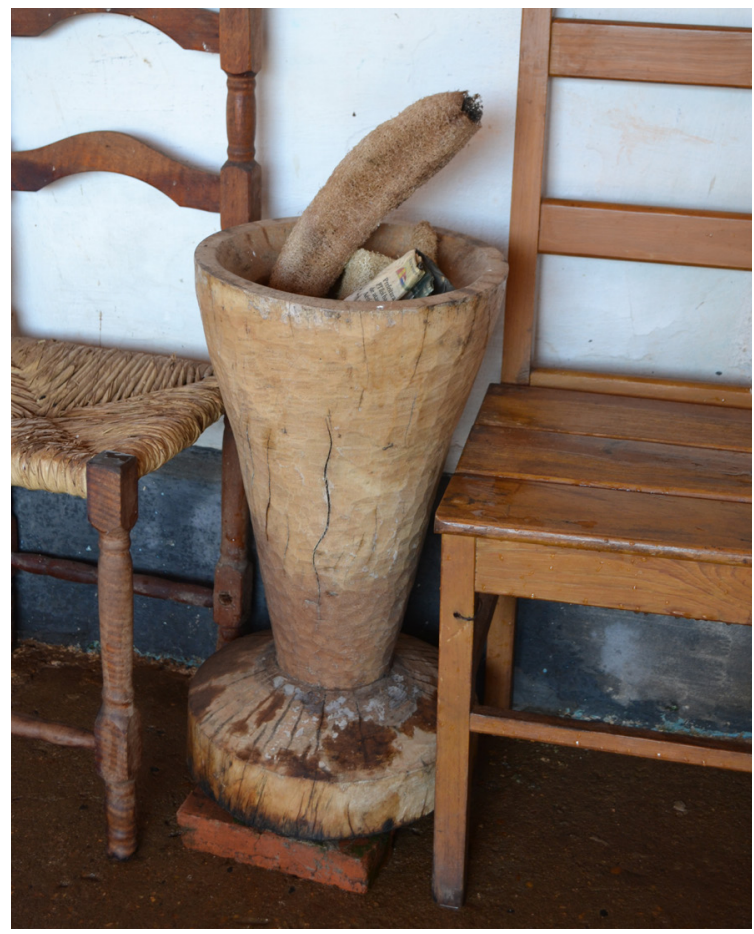

Figura 32. Pilão fora de uso acomoda objetos diversos. Laranjal Paulista. Foto: Eliete Soares, 2014.

Ainda sobre os dados obtidos nesta análise, 10\% dos artefatos estão ligados a cultos ou oferendas religiosas. Neste caso, o dado confirma outro aspecto interessante desta população, a religiosidade. A totalidade da amostra é cristã, de maioria católica; das vinte famílias visitadas, apenas uma se declarou evangélica.

Pudemos observar pequenos altares para culto e devoção de santos católicos em catorze das vinte residências visitadas: neles, sempre presentes uma ou mais imagens de santos (a maior ocorrência é de Nossa Senhora Aparecida) e flores, tanto naturais quanto artificiais, em sinal de devoção. 
Não raro, encontrou-se, junto à imagem sacra, um porta-retratos com a fotografia de algum parente falecido, numa espécie de homenagem, uma vez que nas orações pede-se proteção àqueles que já faleceram (Figura 33).

A Bíblia também estava presente em dez casas; tanto fechadas sobre algum móvel, ao alcance da vista, quanto abertas na página a ser lida, ou expostas num suporte de bronze ou madeira como objeto de valor simbólico e estético (Figura 34).

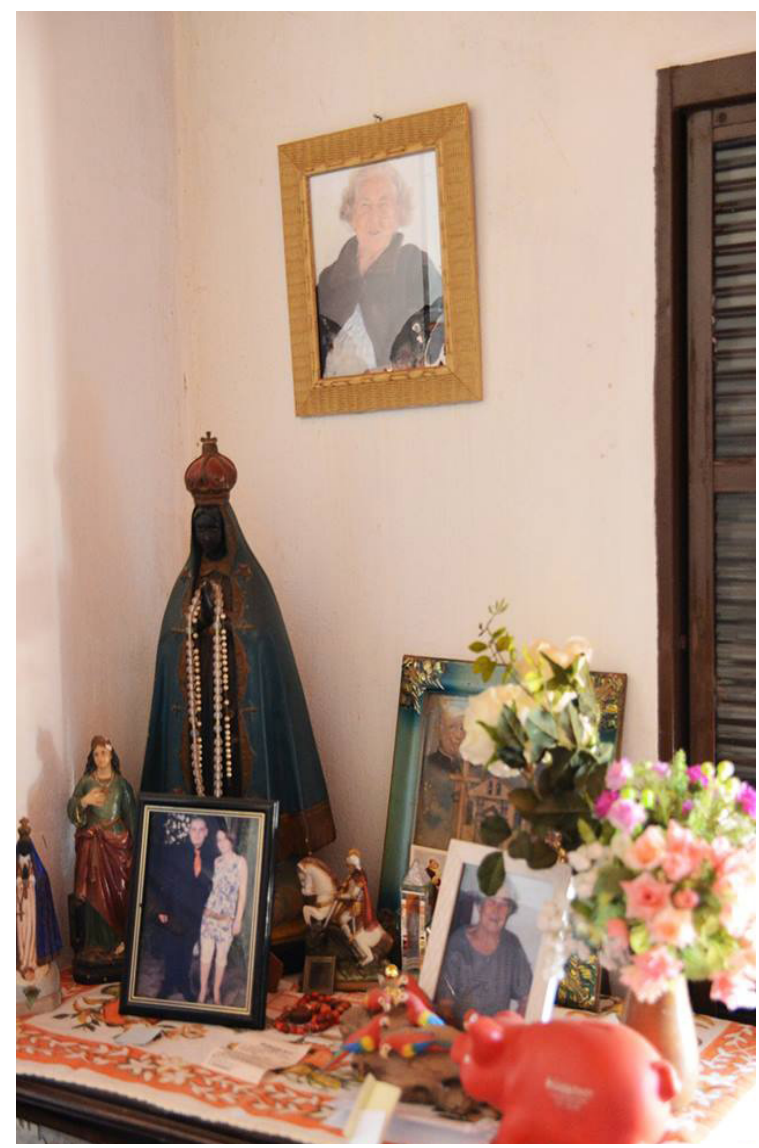

Figura 33. Altar doméstico com imagens de santos, flores e fotografias de parentes falecidos. Laranjal Paulista. Foto: Eliete Soares, 2014.

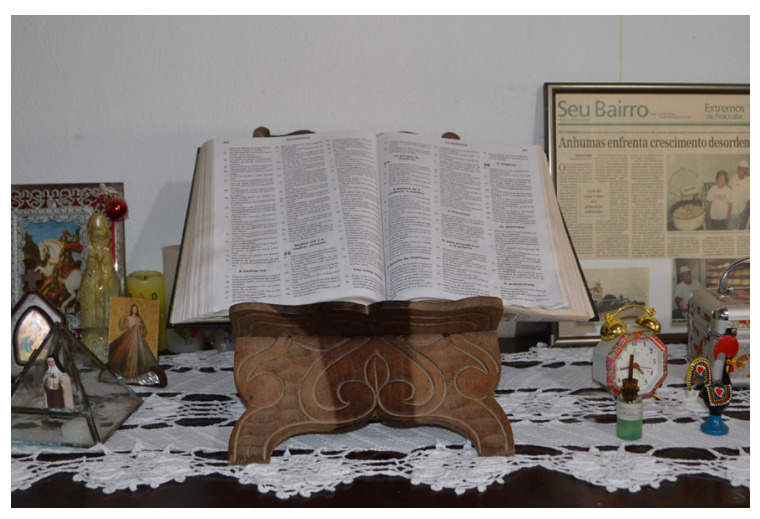

Figura 34. Bíblia no suporte sobre a cômoda no quarto: funcionalidade e preocupação estética. Piracicaba. Registro fotográfico da autora, 2014.

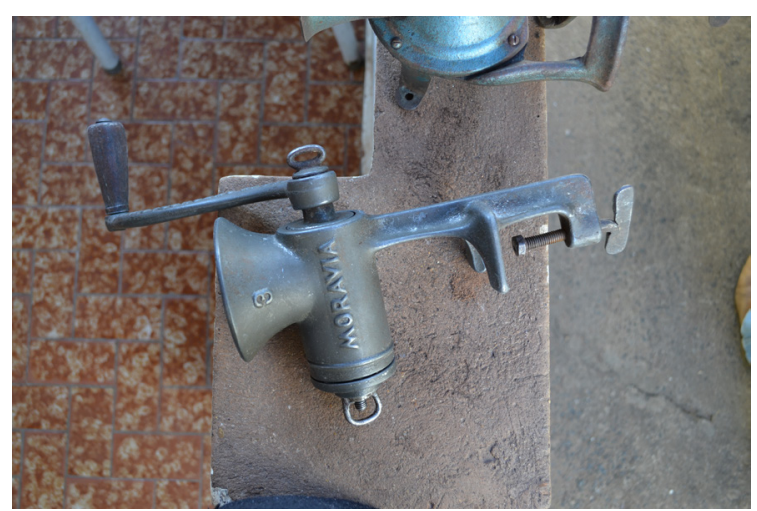

Figura 35. O passado no sítio materializado: moedor de carne guardado como relíquia. Monte Aprazível. Registro fotográfico da autora, 2014.

Vale ainda ressaltar, nesta análise, a incidência de artefatos chamados de "relíquias" pelos moradores (5\%). Esta subcategoria se sobrepõe à categoria "enfeite" em alguns casos, como o ferro de passar a carvão da mãe da entrevistada que virou enfeite sobre o móvel, e tantos outros objetos sem função nos dias de hoje que são mantidos guardados, fora do alcance da vista, simplesmente por "se tratar de uma relíquia", de acordo com a fala do próprio morador ao se referir a um moedor de carne (Figura 35). Este artefato foi largamente utilizado no passado, no preparo de linguiça a partir das sobras do porco abatido no sítio. A relação emocional com o passado materializado naquele objeto não permite que ele se desfaça do mesmo, ainda que não seja mais utilizado.

Finalmente, aparecem nove artefatos (10\%) destinados à proteção, seja de um móvel, do piso ou mesmo de outro objeto: aqui, incluem-se toalhinhas e os chamados "guardanapos" que cobrem toda sorte de objetos como a talha, o botijão de gás, a geladeira, a tampa de vidro do fogão, as prateleiras dentro do armário ou da cristaleira, até mesmo a gaiola do papagaio (Quadro 6). 

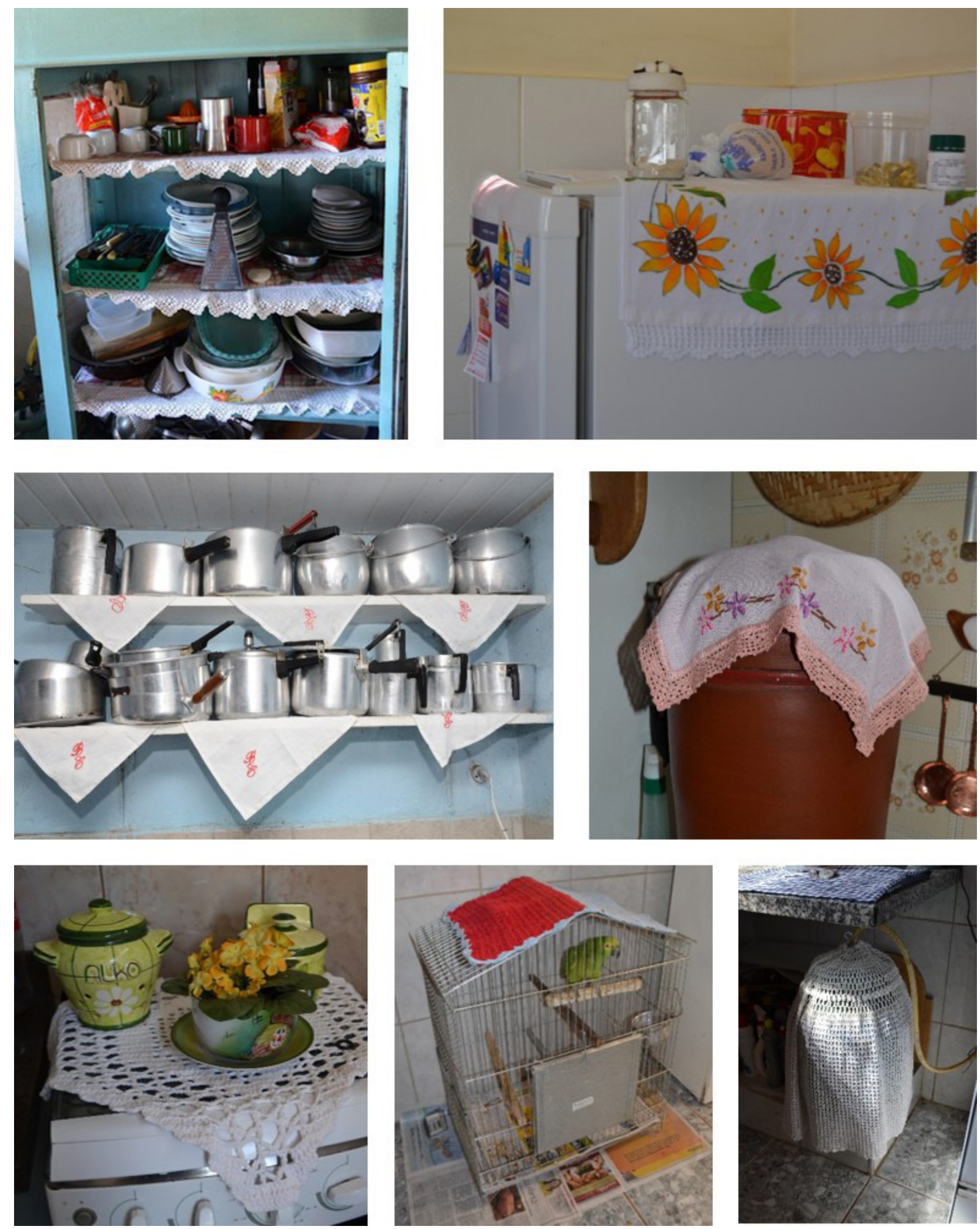

Quadro 6. Toalhinhas e guardanapos protegem objetos e móveis. Registros fotográficos da autora, 2014 (à exceção do paneleiro, foto: Eliete Soares). Da esquerda para a direita e de cima para baixo: toalhinha cobre as prateleiras, Laranjal Paulista; pano de prato sobre a geladeira, Rio Claro; prateleiras do paneleiro cobertas com guardanapos bordados, Botucatu; cobre talha, Campinas; toalha de crochê sobre o fogão, Piracicaba; crochê protege a gaiola e o botijão de gás, Piracicaba.

Em alguns casos, notou-se a intenção legítima de proteger um objeto de poeira cobrindo-o com a referida toalhinha. Por outro lado, ficou a indagação se esta não seria uma justificativa para a prolífica produção das toalhinhas de crochê, um dos passatempos mais citados pelas senhoras entrevistadas. Enquanto uma colcha de crochê leva meses para ser produzida e é, portanto, mais rara de ser encontrada (o que 
justifica o tom de orgulho das três entrevistadas em cujas casas este item foi observado), as toalhinhas consomem pouca linha e são rapidamente confeccionadas. Sendo assim, como dar vazão a esta produção? Tratando de utilizá-las sob vasos, fruteiras, telefones e santos, de modo a proteger o móvel. Notou-se ainda, com relação à prática dos pequenos artefatos de crochê, que existe o hábito de se presentear parentes e pessoas conhecidas com toalhinhas ou tapetinhos de própria autoria, em sinal de consideração e, finalmente, a existência dos bazares da comunidade ou da igreja, onde compra-se para ajudar, o que aumenta sobremaneira a incidência deste artefato nas casas.

Outra subcategoria desta análise refere-se às questões de ergonomia e usabilidade dos objetos. Com relação elas, pudemos observar alguns pontos interessantes: por se tratarem de objetos utilizados no cotidiano de pessoas comuns, são, em sua maioria (39\%), fáceis de usar e não requerem conhecimento prévio para tanto (Gráfico 6).

Porém, devido ao alto índice de objetos utilizados apenas para enfeitar, a análise não se aplicou em metade dos objetos avaliados, pela falta de interação com o usuário.

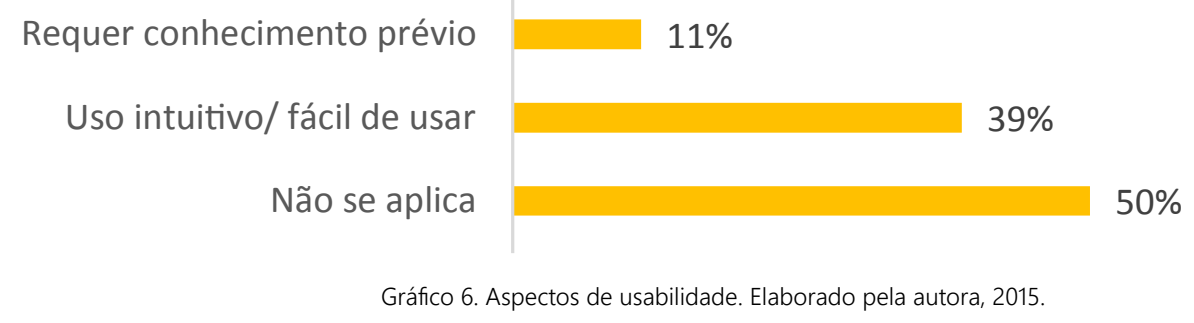

Entre aqueles utilizados em diferentes funções, 30\% apresentaram uma exigência baixíssima de manejo e controle e 13\% uma baixa exigência de manejo e controle. Estes números revelam o quanto estes objetos são, em geral, simples de se operar (Gráfico 7).

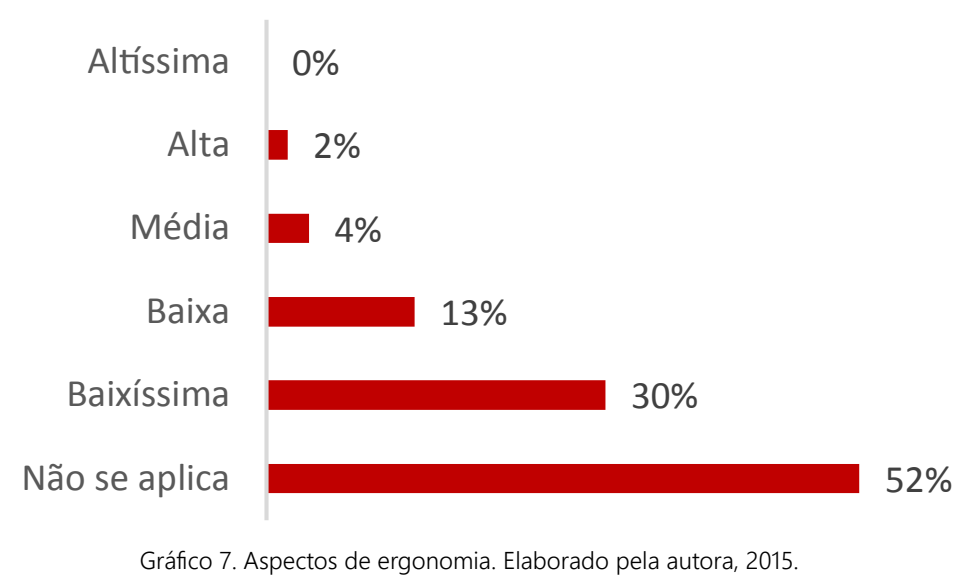


Apenas um único objeto considerado de alta exigência foi identificado: a máquina de costura. Foi interessante observar, porém, que mesmo demandando um conhecimento prévio para ser utilizada, a maioria das respondentes aprendeu a costurar apenas observando alguma pessoa mais velha e experiente, que transmitiu de modo oral este saber aos moldes de qualquer fato folclórico.

Com relação ainda a aspectos de uso relativos à facilidade e ao prazer de operar o produto (NORMAN, 2008), gostaríamos de destacar o caso da vassoura de palha, objeto presente em 14 das 24 residências, considerado, pelos usuários, como mais eficiente e duradoura do que a vassoura de plástico ou de piaçava.

Porém, do ponto de vista dos aspectos fisiológicos de uso, a vassoura de palha, quando nova, é desconfortável para varrer, pois sua palha é rígida e sua base é reta (Figura 36). À medida que é usada, a palha se torna mais maleável e se desgasta de forma irregular, deixando sua base angulada e ligeiramente curva, o que melhora consideravelmente o ato de varrer, ou seja, sua ergonomia é facilitada pelo tempo de uso (Figura 37).

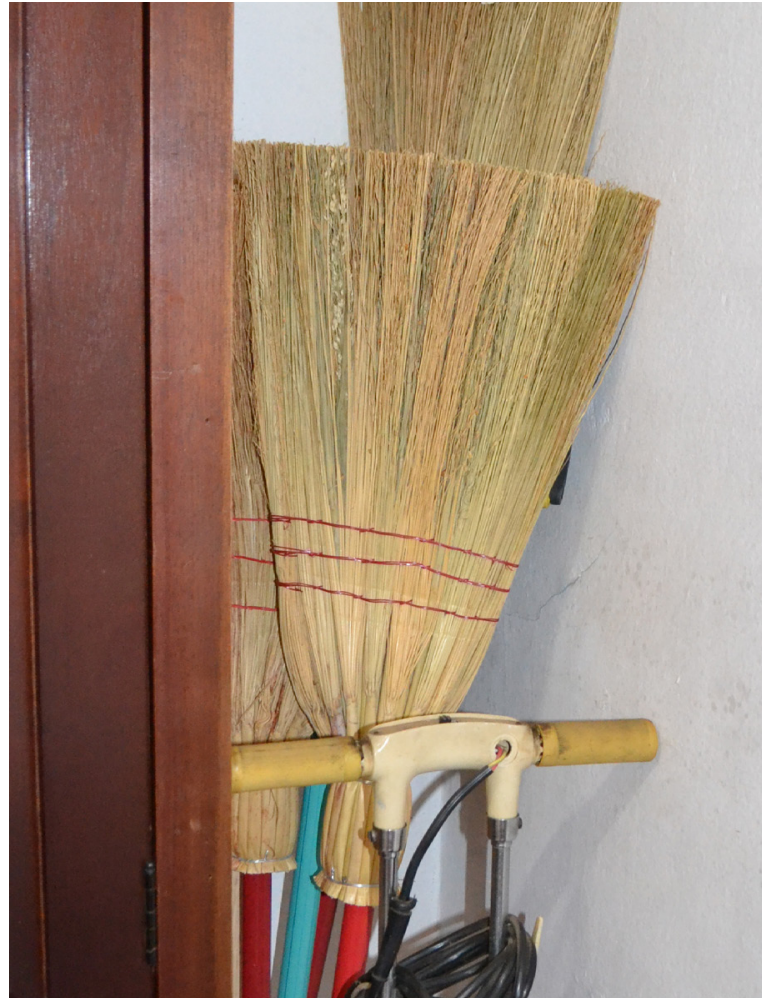

Figura 36. Vassoura de palha nova. Piracicaba. Registro fotográfico da autora, 2014.

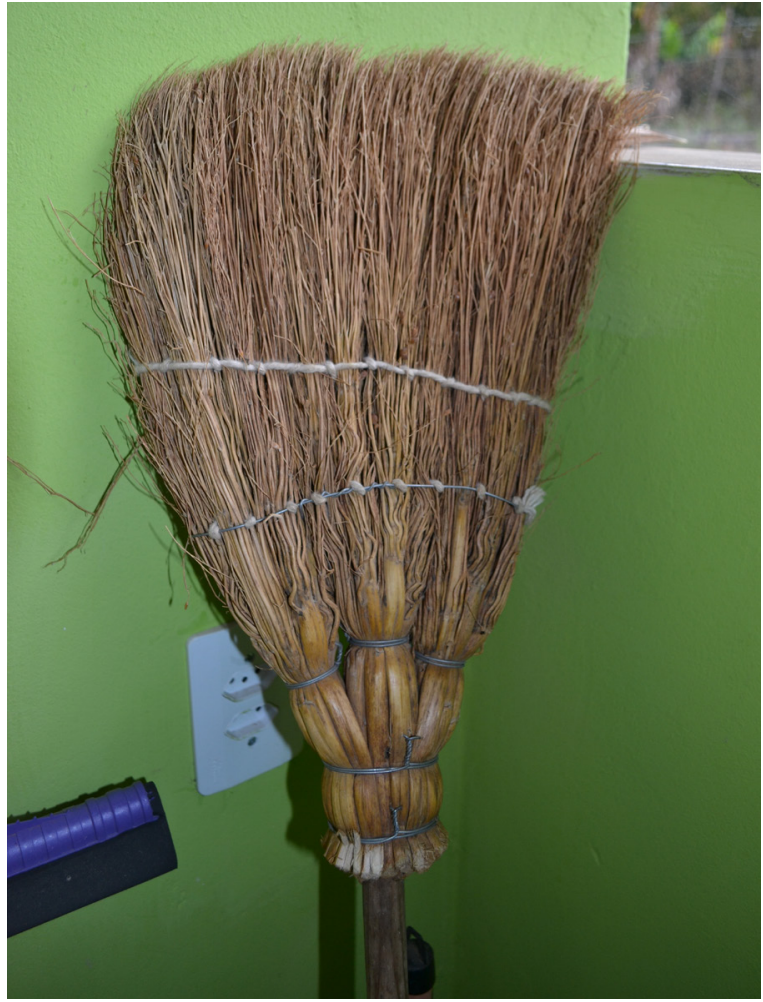

Figura 37. Vassoura de palha usada, com formato arredondado pelo uso. Limeira. Registro fotográfico da autora, 2014. 


\section{Análise da dimensão relativa ao significado}

Antes de pensarmos nos significados dos objetos e seu simbolismo, foi necessário compreender a origem do objeto na casa, sua origem - se foi comprado, herdado, produzido pelos moradores, entre outros (Gráfico 8).

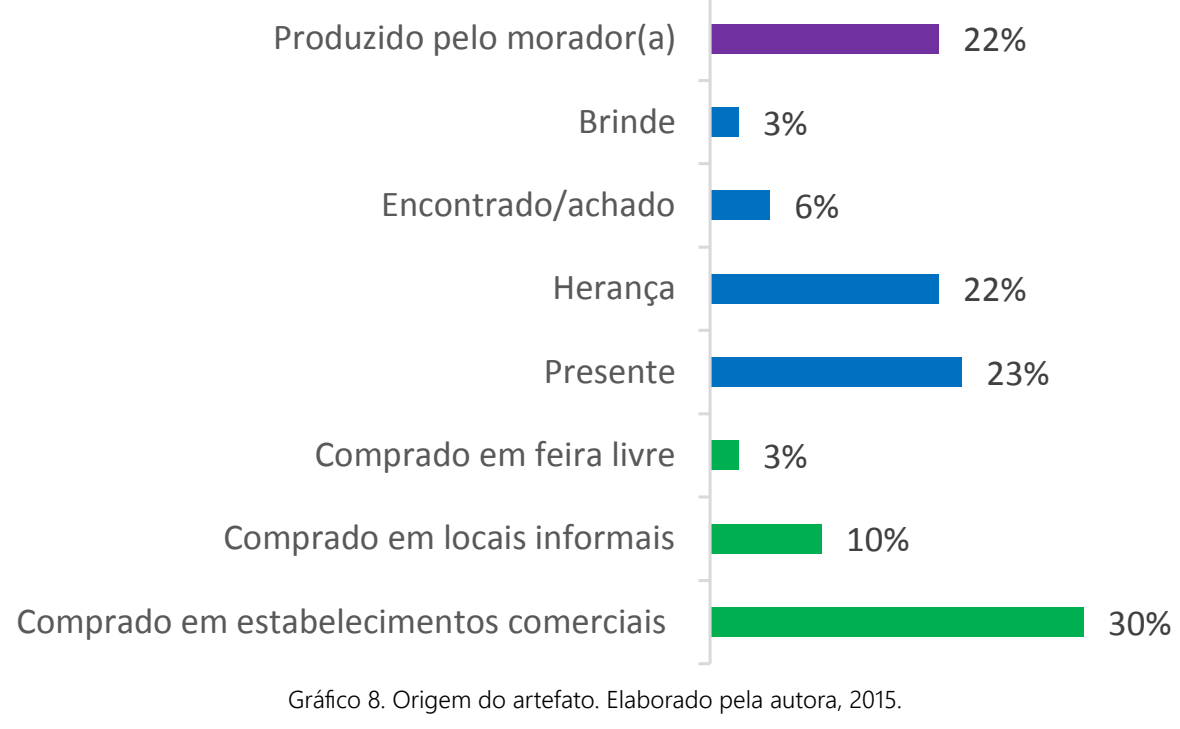

De um total de 96 relatos a respeito da origem dos objetos na casa, em menos da metade dos casos o objeto foi comprado, seja em estabelecimentos comerciais regulares, seja em lojas e mercados, feiras, bazares ou ainda de vendedores porta-a-porta (43\% das ocorrências, barras em verde). Já em $54 \%$ das vezes (barras em azul), o objeto não foi comprado pelo morador: trata-se de presente, herança, brinde ou foi achado em algum local público (na rua, no mato) e o sujeito se apropriou dele. Pudemos inferir, a partir destes números, que não se trata, portanto, de uma população com um viés consumista evidente.

Em 22\% dos casos (em roxo), o objeto foi produzido pelos moradores, o que reforçou a herança histórica e social da família como unidade autônoma de produção, típica dos bairros rurais paulistas (DE QUEIROZ, 1973), onde a distância dos centros das vilas e das cidades obrigava à autossuficiência por uma questão de sobrevivência. Assim, os saberes e as habilidades manuais, desde as costuras de colchas e toalhinhas até os serviços de marcenaria (como a confecção de um relicário para o santo protetor) eram passados de geração a geração de forma inquestionável.

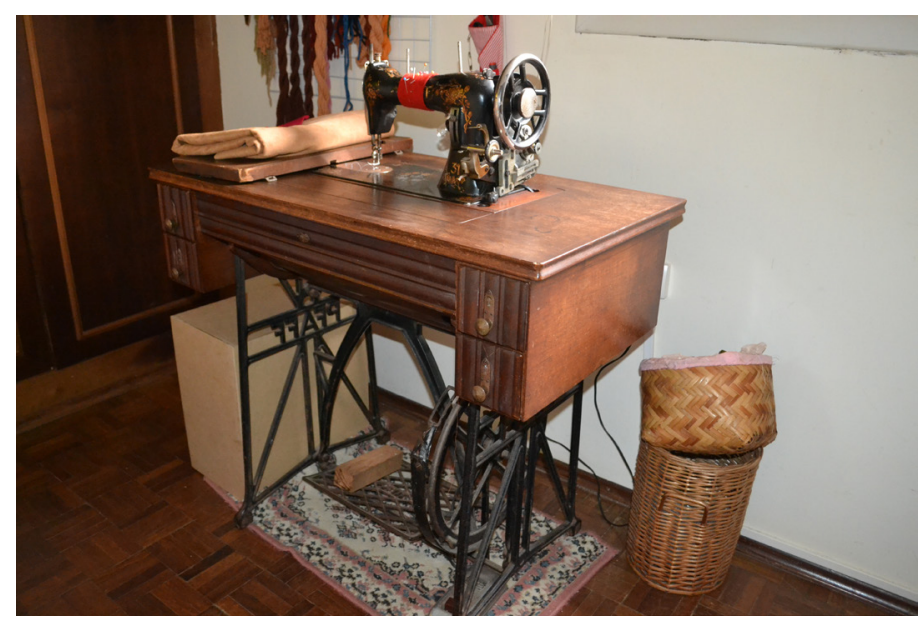

Figura 38. Máquina de costura em uso. Campinas. Registro fotográfico da autora, 2014.
Das vinte residências visitadas, a máquina de costura (Figura 38) estava presente, em uso, em doze delas; em outras duas, a máquina foi doada, pois as moradoras, idosas com problemas de visão, não conseguem mais executar os serviços de costura. Em sua maioria, a máquina de costura foi um presente de casamento ou herança de uma parente idosa nas condições relatadas acima. 


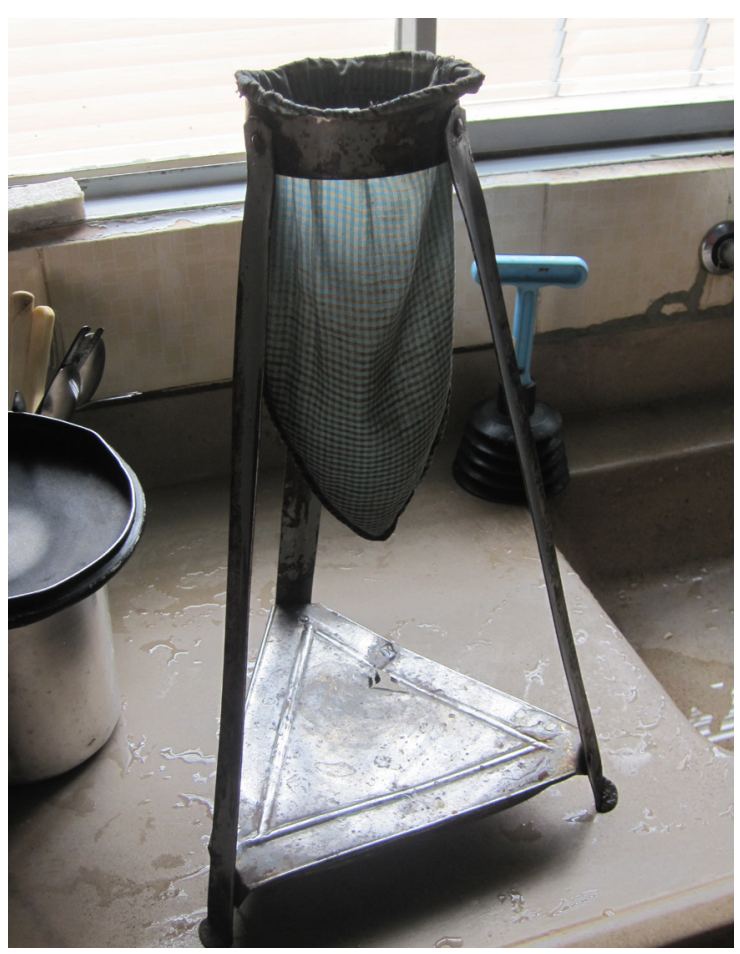

Figura 39. Coador de pano feito pela moradora a partir de sobras de tecido. Monte Aprazível. Registro fotográfico da autora, 2014.
Ainda com relação à casa ser uma unidade autônoma de produção, destacamos a vassoura de palha, produzida por duas irmãs moradoras de um sítio em Limeira, descendentes de colonos alemães, ou o coador de pano para café, cuja parte de tecido se troca com o tempo, à medida que fica demasiadamente encardida ou furada - para tanto, pode ser feita a partir de sobras de tecido sobre a estrutura existente, reaproveitando-a, como se pode observar na Figura 39 onde o tecido utilizado é uma popeline de algodão com uma estampa xadrez verde, sobra de um corte de tecido utilizado na confecção de um vestido da neta da moradora de Monte Aprazível.

Depois de se compreender algumas destas questões, partimos para os dados obtidos na análise dos significados (Gráfico 9).

\begin{abstract}
Estar na moda
Companhia/não está sozinha
\end{abstract}

Status

Superstição

Desafio

Gesto de hospitalidade

Amor familiar

Origem/tradição imigrante

Habilidades manuais tipicamente masculinas

Proteção

Não desperdício/ não jogar fora

Pertencimento a uma comunidade/bairro

Origem/tradição rural

Devoção/fé/crença religiosa

Hábito/ costume/ segurança

Habilidades manuais tipicamente femininas

$$
\text { Relíquia }
$$

$0 \%$

$1 \%$
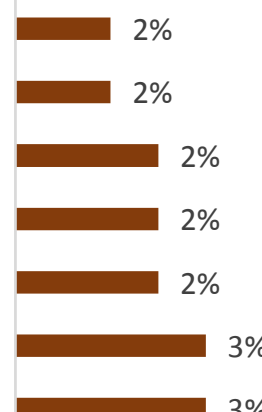

$3 \%$

$4 \%$
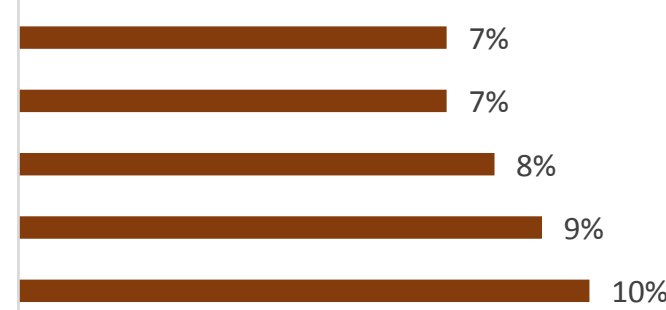

$10 \%$

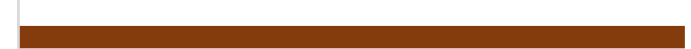

$11 \%$

Gráfico 9. Aspectos relacionados ao significado dos artefatos. Elaborado pela autora, 2015. 
A maioria das situações analisadas indica que os artefatos simbolizam o "cuidar de casa", atividades que se relacionam como papel de mulheres. Estamos, portanto, falando do universo feminino no lar. Pudemos perceber, por exemplo, através de alguns relatos, que estender o pano de prato decorado sobre o fogão ao final da tarefa de arrumar a cozinha após o almoço simboliza o cuidado da mulher com a casa e, por extensão, com a família. Na mesma linha, pudemos entender vários dos objetos destinados a enfeitar a casa, listados na análise pragmática. Muitos são símbolos do cuidado feminino com o lar, como, por exemplo, os paninhos que enfeitam as prateleiras ou os paneleiros expondo panelas competentemente areadas.

Neste, como em outros casos, o significado atribuído aos objetos ou à maneira de expô-los está atrelado a outro item listado na tabela acima, que diz respeito às habilidades manuais tipicamente femininas. $O$ fazer manual das costuras e bordados, as panelas areadas, as toalhinhas de crochê enfeitando os móveis, todos estes objetos transmitiram-nos a mensagem de cuidado pela casa e pela família, mas com um aspecto ainda mais pessoal, por terem sido feitos pela própria moradora.

Outro significado intrínseco ao objeto foi relativo à segurança. Neste item, encontram-se objetos relacionados ao costume ou ao hábito, com relatos do tipo "porque sempre fiz assim"; "foi assim que eu aprendi desde criança"; "porque estou acostumada". Por traz destas observações, pode-se identificar um sentimento de segurança atribuído ao hábito ou ao costume de sempre se fazer de um mesmo modo. Pudemos induzir, por estes dados iniciais, que há um maior apego pelo que se faz há certo tempo do que pelo novo.

Na mesma linha, há os objetos que simbolizam a tradição rural, tanto para aqueles de origem caipira quanto para os descendentes de imigrantes, como o fogão a lenha (Figura 40) ou o tacho de cobre para fazer doce e sabão de cinzas (Figura 41), ou ainda o moedor de carne usado na produção de linguiça de porco. Mesmo que não utilizados, existe um sentimento de pertencimento a um grupo ou uma comunidade associado a eles, exemplificado em alguns relatos: "a gente não usa mais, hoje em dia, compra tudo pronto; mas era do meu pai, fizemos muita linguiça no sítio, era uma festa... distribuía pros vizinhos."

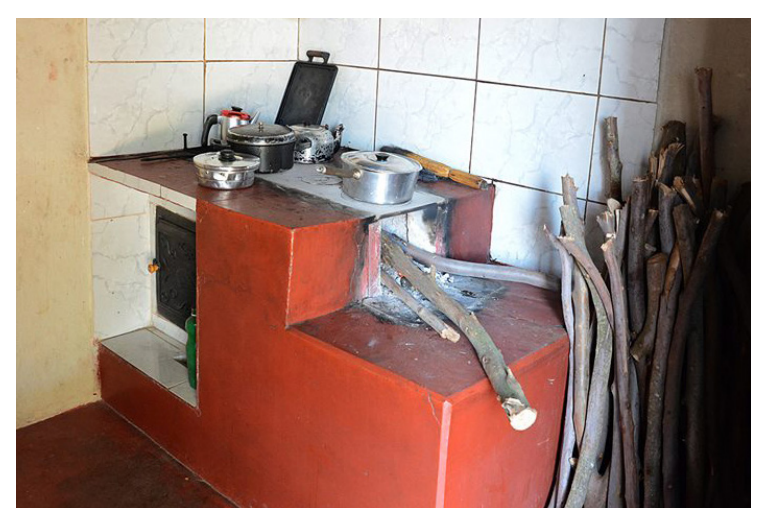

Figura 40. Fogão a lenha. Laranjal Paulista. Foto: Eliete Soares, 2014.

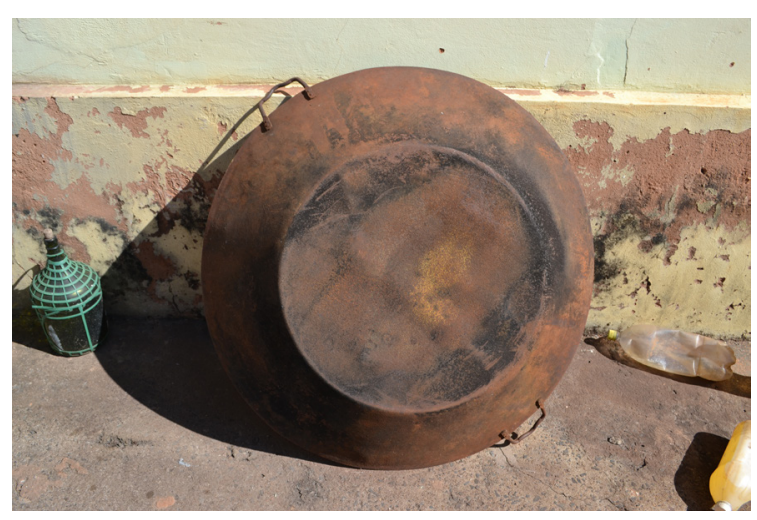

Figura 41. Tacho de cobre para fazer sabão de cinzas. Monte Aprazível. Registro fotográfico da autora, 2014.

Pudemos aludir às práticas vicinais dos mutirões dos caipiras (CANDIDO, 1987) e relacioná-las ao sentimento de pertencimento a um grupo ou uma comunidade, através do relato de senhoras que compram toalhinhas de crochê ou panos de prato para ajudar alguém no bairro. A mesma percepção se tem em relação 
ao uso do pilão no mês de julho, como já citado, para fazer uma grande quantidade de colorau muito superior ao consumo de uma família, que depois se distribui entre parentes e vizinhos; ou ainda pelos vários calendários ganhos no comércio local, pendurados sobrepostos atrás da porta da cozinha, mantidos ali "por consideração" a quem os deu.

Nesta análise, vale ainda ressaltar a mensagem de reaproveitamento explícita em certos objetos ou práticas relacionadas aos artefatos listados, como fazer o colorau mesmo em excesso para não perder as sementes do urucum que só dão uma vez por ano; os tapetinhos, as almofadas e as colchas feitas de retalhos, assim como trocar o paninho do coador de pano; os crochês coloridos com restos de novelos utilizados em outros trabalhos; defumar a banha de porco no calor do fogão a lenha e fazer sabão das cinzas dele.

É importante ressaltar que o conhecimento para se fazer o colorau, o sabão de cinzas, as almofadas ou a defumação da banha de porco foi todo transmitido de modo oral entre pessoas de gerações diferentes, o que reforçou a temática folclórica desta pesquisa.

Um dado interessante desta fase de análise se refere à noção de status: apenas duas vezes pudemos observar esta relação simbólica.

Primeiramente, o copo "bico de jaca". Vale relatar que, em todas as residências visitadas, ofereceram-nos água e café. E, na maioria das vezes, o copo utilizado para a água da visita, no caso, a pesquisadora, era um copo desse tipo (Figura 42), escolhido dentre os vários outros no armário (como copos "americanos" e "de requeijão"). Mais de uma vez, ouvimos o relato sobre o jogo de copos ter sido dado como presente de casamento, "pois naquela época era chic".

O segundo caso foi com pratos de porcelana que enfeitavam paredes. Uma senhora entrevistada tinha vários deles em suportes próprios, enfeitando a estante da sala de jantar e da copa (Figura 43).

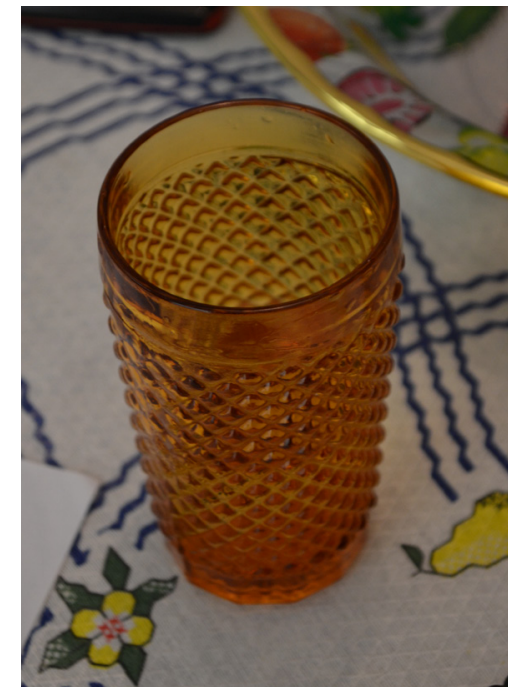

Figura 42. Copo "bico de jaca" para as visitas. Piracicaba. Registro fotográfico da autora, 2014

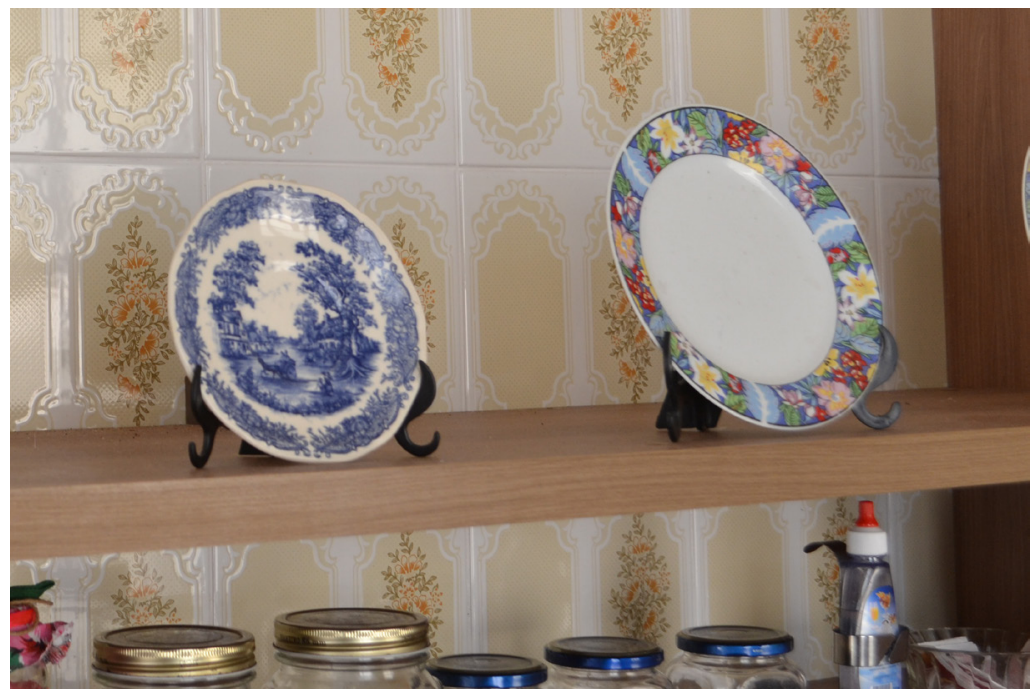

Figura 43. Prato de porcelana industrializado desmerece a coleção. São Luís do Paraitinga. Registro fotográfico da autora, 2014

Durante a visita, ao ser perguntada sobre os pratos, ela se desculpou por alguns não serem pintados à mão e sim decorados industrialmente, expostos junto aos mais "nobres". Neste caso, pode-se ainda associar o fazer artístico àquilo que confere valor ao objeto, portanto, seu status provém do reconhecimento de uma habilidade, a pintura de porcelana. Diferentemente do copo "bico de jaca", cujo valor provem do fato de 
ter sido um objeto muito em moda nas casas especializadas de louças e presentes domésticos nas décadas de 1960 e 1970 e por se tratar de um objeto de herança histórica dos portugueses - que o introduziram no Brasil em 1901 por meio do catalogo da Fábrica de Vidros da Marinha Grande, de Portugal (COPOS, 2009).

\section{Análise do confronto dos artefatos com as memórias}

Alguns fatores puderam ser observados quando apresentamos os objetos, por meio de suas fotografias, aos respondentes, cujas memórias haviam dado origem à lista de artefatos memoráveis a serem pesquisados em campo.

O primeiro ponto interessante foi a observação de que um gatilho no presente, como, por exemplo, a foto de uma caneca de ágata, dispara a memória de fatos do passado, que vêm à tona como uma enxurrada de lembranças traduzidas em uma narrativa desconexa, como se pode perceber na fala de um respondente, transcrita a seguir:

\footnotetext{
A gente usava copo pra tomar café. A outra coisa que isso me faz lembrar, é que era comum, principalmente na casa da minha tia Aparecida, meu tio Vitor colocar um pouco de café pro São Benedito. Eu me lembro que, na minha casa, meu pai e minha mãe chegaram a instituir isso quando eu era pequeno, mas com o tempo isso foi se perdendo. Nem na casa da minha mãe hoje, que ela tá com 80 anos, ela tem esse habito. Assim, principalmente na casa da minha tia Aparecida e tio Vitor em São Carlos... Porque essa minha tia é irmã da minha avó que morreu jovem, e a minha mãe foi meio que protegida pelas tias; como meu avô casou e ela não morou com essa outra família que meu avô foi constituindo, ela [a mãe] foi criada pela avó dela e pelas tias... Então, minha mãe teve muitas mães, relações afetivas, tal, e essa minha tia lá de São Carlos, me lembro muito disso, na casa dela, que eu via as imagens de santo, mas ágata, caneca, não me lembro (B. C. G. C., 55 anos).
}

Também foi-nos possível perceber que lembrar promove uma fuga do presente na qual quem recorda se transporta para momentos que ficaram no passado, muitas vezes perdendo-se no tempo das histórias, esquecendo-se até do motivo daquelas imagens a sua frente e da própria presença da pesquisadora.

Pudemos observar que alguns marcos inesquecíveis estão vinculados intimamente a determinados artefatos, como a lembrança de uma respondente ao ver as fotografias da máquina de costura: "A minha irmã costurou uma unha com a máquina (risos)... Era uma dessas máquinas de pedal, ela aprendeu com a minha avó" (A. R. G. G., 42 anos).

Muitas vezes, o objeto mencionado tem seu uso atrelado a uma espécie de rito que unia a família ou mesmo vizinhos e parentes distantes.

Moedor de carne minha mãe teve quando eu era criança, era bem desses de prender na mesa. A gente curtia muito, era tipo um ritual moer carne, todo mundo queria mexer um pouquinho (C. C. S., 42 anos).

Ainda com relação aos ritos, os objetos religiosos são aqueles que mais facilmente evocaram as memórias ritualísticas. "Olha o ramo do Domingo de Ramos no crucifixo; minha vó colocava. Tá (sic) seco, põe e fica lá. Aí, quando tem alguma tempestade, você queima o galhinho" (A. R. G. G., 42 anos). "Eu tinha medo do crucifixo de metal que ficava em cima da porta" (D. Z., 45 anos).

Ao começar a manusear as imagens, mais de uma vez pudemos observar o entrevistado passar a discorrer sobre suas lembranças, que se alinhavavam com outras e outras, a ponto de se desligar completamente das fotografias e se enveredar em casos e histórias de sua infância, descrevendo locais e situações com visível prazer. 
Eu chegava na casa da minha avó, ela tava (sic) sentada na máquina de costura; eu ficava fascinado com aquelas gavetinhas. A máquina tinha um "compartimento secreto" pra onde ela era recolhida depois de usar pra que ela ficasse disfarçada como uma mesinha e fizesse dupla função. Lembro muito dos móveis da casa da minha vó, ela tinha um sofá de madeira que era preto e com estofado marrom com botões enormes. Ela ficava sentada tricotando toda noite enquanto assistia TV (A. A., 42 anos).

As imagens dos objetos despertaram lembranças que, muitas vezes, vinham à tona de modo desordenado, fazendo o respondente voltar no tempo, reconstruir histórias que eventualmente nem foram vividas por eles mesmos e que constituem uma memória herdada. É o que se pode notar na passagem deste respondente ao ver as imagens de fogão a lenha:

Outra coisa que me lembra também o fogão a lenha é da minha avó fazer sabão. Isso lembra bastante. E também tem a coisa de aquecer também o ambiente. Agora tanto lá em Santa Eudóxia... Porque minha mãe, quando ela nasceu, morreu a mãe dela, 10, 15 dias depois. Minha avó morreu com 27 anos. Aí a minha mãe foi criada pela avó, meu avô casou de novo, ela tinha um irmão e depois meu avô teve mais dois filhos. Mais eu me lembro muito da casa da madrasta da minha mãe, o fogão a lenha. E na casa da minha vó em São Carlos também, mesmo ela morando na cidade, que não é mais enfim uma área rural, na casa dela tinha lá o fogão e o café era feito ali (B. C. G. C., 55 anos).

Também se notou como pode funcionar a memória compartilhada de uma geração para as seguintes, como uma herança preservada, na fala de uma respondente em relação às imagens de santos e à própria história de vida de seu avô:

Meu avô era muito religioso, mas não tinha um preferido, dependendo do santo que tivesse no momento ali... O meu pai, por exemplo, conta muito do tempo do sitio; eu peguei os resquícios do sitio, os hábitos, [o fato de que se] economizava comida... eles vieram [fugindo] da fome na Itália... meu avô foi usar sapato a primeira vez aos quatorze anos (D. R. R. R., 42 anos).

Em certas passagens, observou-se a necessidade de se preservar a memória da família e seus hábitos por meio de um objeto que lhe é tradicional. É o caso do galinho português que a respondente A. R. G. G. citou, na primeira fase do trabalho, como um objeto da casa de sua tia-avó pelo qual era fascinada, por conta das mudanças de cor em função do clima. Agora, ao ser apresentada à sua imagem fotográfica, declarou:

Isso é muito simbólico pra mim, o galinho em cima da geladeira, e eu ficava [pensando]: o galinho é mágico, muda de cor. Agora que eu fui pra Portugal eu comprei um pra minha filha; nossa, amei! (A. R. G .G., 42 anos).

Outro ponto relevante diz respeito à dualidade de sentimentos que se pode identificar em relação a este passado familiar. De um lado, foi possível perceber o orgulho do entrevistado pela origem mais humilde dos antepassados se comparada a sua situação sociocultural atual, denotando uma melhoria de vida na família ao longo do tempo, como ilustra a fala do respondente sobre sua avó, ao ver as fotos da máquina de costura: "Ela costurava, dava um duro danado, criou sete filhos... A gente deve tudo a ela" (J. C. B., 58 anos).

Por outro lado, também foi possível perceber a crítica a alguns hábitos e valores dos antepassados, como a do respondente D.Z. em relação ao vaso de porcelana com flores artificiais:

Minha mãe adora uma flor artificial e eu consegui "limar" muito do que ela adora... Nós substituímos por flores de palha, artificial ainda, mas um pouco melhor (D. Z., 45 anos).

Ainda sobre as flores artificiais, a respondente A. R. G. G declarou enfática: "Ah, isso eu sempre achei super brega!", para depois se redimir: "Mas tem algumas coisas que são cafonas que eu acho super legal." 
Diante da imagem das porcelanas "desparceiradas" e seu comentário, pudemos observar um fenômeno de apropriação cultural.

É muito legal. Eu fui num restaurante em Portugal que era assim: um prato de cada jeito, cada xícara de um modelo.

A gente acha lindo, né. Mas eles (os avós) não acham, é meio que demonstrar pobreza (A. R. G. G., 42 anos).

Sua declaração suscitou-nos uma constatação sobre a ressignificação de um objeto e suas inter-relações culturais. Primeiramente, há uma atitude de resistência de alguns indivíduos em relação à cultura de massa (neste caso, um dono de um restaurante em Portugal) chamados de alternativos, que se apropriam de certas referências populares inicialmente consideradas bregas pelo mainstream, como uma alternativa à moda e aos padrões impostos pela massificação. Porém, no momento seguinte, a própria indústria cultural se apropria desta proposta, reapresentando-a como um fenômeno novo e criativo, aplicando-o o rótulo de cult, para associá-la a um ideal de exclusividade àqueles que querem se diferenciar da cultura de consumo das grandes lojas e mídias. Aquilo que antes se considerava brega, agora é descolado e chic, porém, o que se pode notar a seguir é uma nova ressignificação do objeto. Incorporado ao sistema de reprodução em larga escala do capitalismo, tão logo sua distribuição atinja as massas, aqueles primeiros consumidores alternativos deixarão de desejar o objeto por não pertencer mais à categoria do exclusivo, como se este perdesse sua aura benjaminiana.

Desta forma, aquilo que para os idosos daquela camada popular não tinha valor estético, pois denotava uma situação de pobreza, transforma-se em mito cult para, em seguida, voltar a ser desprezado novamente quando passa a denotar outro sentido do popular, o da massa, num processo de circularidade cultural.

O mesmo pode-se observar com relação à roseira e à samambaia.

Roseira, era tão bonito, hoje em dia ninguém tem. É que nem samambaia...Toda casa tinha. Teve uma época que era chic ter, né, samambaia de metro, quanto mais comprida mas chic. Agora ninguém mais tem (D. Z., 45 anos).

Em sua opinião, "ninguém mais tem", pois sua referência trata de um universo socioeconômico mais elevado que de seus antepassados, em que estes dois elementos passaram a ser considerados "fora de moda" ou "antiquados", ou mesmo pejorativamente "populares" pelos profissionais paisagistas e pela mídia especializada, como revistas e blogs de decoração e paisagismo, por exemplo.

Se a respondente dirigisse seu olhar para os quintais e os jardins das casas existentes nos bairros de gente antiga e tradicional de sua cidade, provavelmente veria que as samambaias e roseiras continuam lá, num misto de conformismo e resistência. 
Conclusões 
Ao pesquisarmos os artefatos domésticos presentes nas casas de gente simples de origem rural no estado de São Paulo, que fazem parte das memórias de adultos, cujas lembranças da infância estão vinculadas a este contexto, foi possível identificar aspectos que acreditamos caracterizar a identidade do objeto popular paulista. Vários indícios nos permitem afirmar que os artefatos encontrados representam a herança da cultura caipira miscigenada com a cultura dos imigrantes que conviveram, e ainda convivem, lado a lado, nas residências.

Os aspectos estudados, ou seja, as características de uso e de percepção destes artefatos, bem como os significados a eles atribuídos, apontaram-nos uma determinada identidade no design intimamente ligada à sua origem sociocultural, portanto histórica, como descreveremos adiante.

Do ponto de vista da utilização de materiais, foram encontrados tanto artefatos rústicos e artesanais como uma peneira de taquara ou um pilão de madeira provenientes da cultura indígena e, posteriormente, caipira -, como objetos de ferro fundido, herança dos europeus - como panelas e moedores de grãos ou de carne e o ferro a brasa para passar roupa.

A escassez de recursos e de bens materiais característica da cultura dos caipiras nômades e da maioria dos imigrantes que veio trabalhar nas lavouras de café, privados da posse das terras e obrigados a sobreviver com o que Candido (1987) chamara de mínimos vitais, pode ser reconhecida em duas circunstâncias. Primeiramente, notou-se uma confirmação desta situação em relação à economia de certos recursos, ao hábito segundo o qual não se joga nada fora, não se desperdiçam materiais ou sobras, reaproveitam-se velhos objetos ou sobras para a produção de novos. Em segundo lugar, percebeu-se uma negação daquela condição vivida por seus antepassados, como um tipo de compensação por tempos difíceis enfrentados por seus parentes: em oposição ao "mínimo vital", encontramos fartura, principalmente em relação às atividades e utensílios voltados à preparação de alimentos. Estas tarefas são consideradas compensadoras e repletas de significados extrínsecos, vistas como um sinal de amor tanto pelos idosos entrevistados quanto pelos relatos das memórias dos adultos respondentes. As lembranças trouxeram de volta cheiros de alimentos cozidos, famílias em torno da mesa de refeição, bolos e guloseimas feitas pelas avós.

A família continuou a justificar a noção de unidade autônoma de produção, herança dos bairros rurais caipiras, distantes do centro e das vilas. Ainda se produz dentro das casas uma grande variedade de objetos e alimentos, desde vassouras de palha até toalhas de crochê, e as habilidades manuais são passadas para as gerações futuras de modo a garantir a transmissão destes saberes.

A maioria das tarefas domésticas continua, também aos moldes de seus antepassados, a cargo das mulheres. A dedicação e a competência com que executam-nas, apesar de reconhecidas entre as próprias mulheres por meio de elogios e mesmo com uma certa reverência - como a determinadas receitas que só a avó sabe fazer ou um ponto de crochê de difícil execução - não são traduzidas como um valor no núcleo familiar. Esta situação, relatada por Stolcke (1994) em seus estudos sobre os sistemas de trabalho e a estrutura familiar dos imigrantes italianos nas fazendas do café em São Paulo no início do século XX, pode ser verificada quase um século depois.

Estes saberes, que incluem lidar com certos utensílios como moedores de grãos ou uma máquina de costura, são naturalmente passados à frente de geração em geração entre as mulheres, que devem aceitálos e perpetuá-los sem questionamento, por serem considerados um ato de amor. Por vezes, foi possível 
notar inclusive certo ressentimento das mulheres mais velhas em relação às moças das gerações seguintes, netas e sobrinhas, que não cozinham mais ou que não querem aprender a costurar. Como seguir o costume está atrelado à ideia de segurança, pois replica práticas conhecidas e herdadas, o risco de ruptura com a tradição também evidenciou preocupações quanto ao futuro de seus descendentes, com relação a uma possível perda da identidade daqueles grupos.

A casa como uma unidade autônoma também pode ser percebida em relação à religiosidade: a manutenção do ritual religioso doméstico com altares e relicários dedicados a santos, orações e familiares também reflete a herança da casa caipira nos bairros distantes da vila, onde se localizava a paróquia mais próxima. As práticas vicinais de mutirões dos caipiras podem ser observadas, mas não mais na lida com a terra, uma vez que o trabalho no campo passou a ser assalariado. Porém, a ajuda mútua entre mulheres de uma determinada comunidade, comprando toalhinhas de crochê no bazar da igreja apenas com a intenção de ajudar a arrecadar fundos para esta ou aquela causa que consideram válida, foi um bom exemplo do espírito comunitário que resistiu ao tempo, se conectando com as práticas vicinais de camaradagem dos caipiras.

Chamou-nos a atenção, com relação aos atributos relativos à percepção dos objetos, a dualidade da linguagem do universo pesquisado. Enquanto os utensílios essencialmente funcionais eram simples e resistentes, feitos com materiais brutos e sem acabamento, os artefatos destinados às funções estéticas ou ritualísticas eram carregados de informação visual, cobertos de estampas, cores vibrantes e contrastantes, com motivos florais em sua maioria. Mas esta dualidade de linguagem não esteve restrita aos lares do sitiante, do caipira ou do imigrante. Nas visitas ao Solar da Marquesa de Santos e à exposição Modos de morar dos paulistas: 1840-1940, realizadas para contextualização do universo material estudado, pode-se verificar a mesma disparidade de linguagem entre os objetos funcionais e os estéticos presentes nos ambientes das casas abastadas da classe alta naquele período. Pode-se inferir, portanto, que o valor estético para esta população, ligada aos hábitos e costumes herdados, é distinto do aspecto funcional dos objetos, sendo que ela aparentemente desconhece a noção de estética funcionalista defendida pelo design moderno.

Finalmente, vale mencionarmos a evidente disparidade entre o que foi encontrado em campo e o que era visto nas lojas, revistas, sites, concursos de design de objetos domésticos, algo que poderíamos caracterizar como um choque entre culturas. Tendo-se em conta que esta pesquisa se desenvolveu na primeira década do século XXI, período no qual publicações especializadas em design do ambiente doméstico destacam a existência de tendências como cozinhas contemporâneas com linhas retas, eletrodomésticos inteligentes dotados de painéis eletrônicos e cooktops, o que pudemos observar em campo foi a presença de fogões a lenha e utensílios de alumínio areados expostos em paneleiros. Em tempos de máquinas automáticas de café Nespresso, o que se viu sobre a pia das cozinhas foi o bule de alumínio e o coador de pano surrado, com o café pronto na garrafa térmica disposta sobre a toalha de plástico estampado, algumas xícaras de porcelana com motivos e modelos diversos e alguns copos "americanos".

Por questões metodológicas, restringimos a extensão geográfica desta pesquisa ao estado de São Paulo. Mas é preciso compreender que o foco do estudo se deu pelo viés sociológico, por meio da cultura caipira, e não pelo cartográfico. Deste modo, acreditamos ser possível assumir que esta materialidade típica do paulista também se encontra presente em grande parte do sul do estado de Minas Gerais bem como no 
norte do Paraná, onde a cultura caipira também é, historicamente, muito presente. Para comprovarmos esta hipótese, seria necessário replicarmos o método aqui empregado nas regiões acima citadas, o que poderia caracterizar uma continudade deste estudo.

Acreditamos que esta materialidade foi resultante da herança histórica dos povos e do processo de formação da sociedade rural em São Paulo. Para isso, contribuíram: a pobreza da capitania de São Vicente no início da colonização do Brasil; o bandeirantismo e a miscigenação de portugueses e índios; o nomadismo e a falta de posse da terra; os caipiras, seus hábitos e valores; e a convivência com os imigrantes europeus vindos para trabalhar nos latifúndios de café. Deste modo, instiga-nos replicar o método aqui empregado também em outras regiões do país, cujas sociedades sejam oriundas de outros povos e processos de formação, o que poderia resultar em um novo glossário visual típico destes locais. Quem sabe, assim, seria possivel tecermos uma grande colcha de retalhos de identidades regionais, chegando a uma compreensão mais ampla e profunda do artefato popular brasileiro. 
Referências bibliográficas

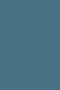 \\ Referências bibliográficas Referencias bibliograficas}

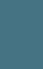

(2) 
ACAYABA, M. M. Equipamentos, usos e costumes da Casa Brasileira. Fichário Ernani Silva Bruno. São Paulo: Museu da Casa Brasileira, 2000.

ALENCAR, J. Til. 2. ed. São Paulo: Martin Claret, 2012.

ALMANAQUE (blog), set. 2000. Disponível em: <http://almanaque.blog.br/tag/jeca-tatu/>. Acesso em: 8 nov. 2015.

ALMEIDA Júnior. In: Enciclopédia Itaú Cultural. Disponível em: <http://enciclopedia.itaucultural.org.br/ pessoa18736/almeida-junior>. Acesso em: 2 jul. 2014.

AMARAL, A. Poesia da Viola. O Estado de S. Paulo, São Paulo, 21 nov. 1921.

O dialeto caipira: gramática, vocabulário. São Paulo: Anhembi, 1955.

Tradições populares. 2. ed. São Paulo: Hucitec; Secretaria da Cultura, Ciência e Tecnologia, 1976.

ANAIS eletrônicos do Congresso Brasileiro de Folclore, v.1, n.1, 2013. XVI Congresso Brasileiro de Folclore - "Comunidades tradicionais populares, folclore e sustentabilidades", 14 a 18 de outubro de 2013, Universidade Federal de Santa Catarina - UFSC, Florianópolis, SC. Disponível em: < http://www.labpac.faed.udesc. br/congresso\%20brasileiro\%20de\%20folclore_anais_edic_atual.htm>. Acesso em: 2 nov. 2014.

ARANTES, A. A. O que é cultura popular. 3. ed. São Paulo: Brasiliense, 1982.

AYALA, M; AYALA, M. I. N. Cultura Popular no Brasil, perspectiva de análise. São Paulo: Ática, 1987.

BARBOSA, R. A Questão Social e Política no Brasil. Conferência pronunciada no Teatro Lírico do Rio de Janeiro em 20 de março de 1919. Introdução de Evaristo de Moraes Filho. Ed. anotada. São Paulo: L Tr Ed; Rio de Janeiro: Casa de Rui Barbosa, 1983.

BARSALINI, G. Mazzaropi - o Jeca do Brasil. São Paulo: Editora Átomo, 2002.

BARDI, L. Uma cadeira de grumixaba e taboa é mais moral do que um divã de babados. Diário de São Paulo, São Paulo, 13 nov. 1949.

Tempos de grossura: o design no impasse. São Paulo: Instituto Lina Bo e P. M. Bardi, 1994.

BAUDRILLARD, J. O Sistema dos Objetos. 5. ed. São Paulo: Perspectiva, 2008.

BENJAMIN, R. Conceito de folclore. Texto publicado pelo Projeto Folclore. São Paulo: Unicamp, 2011. Disponível em: <http://www.unicamp.br/folclore/Material/ extra_conceito.pdf>. Acesso em: 22 out. 2014. 
BERGSON, Henri. Oeuvres. Paris: PUF, 1959.

BOSI, A. Dialética da colonização. São Paulo: Companhia das Letras, 1992.

BOSI, E. Memória e sociedade: lembrança de velhos. 3. ed. São Paulo: Companhia das Letras, 1994.

BUCAILLE, R; PESEZ, J. M. Cultura material. Enciclopédia Einaudi, Lisboa, IN-CM, v. 16, Homo - Domesticação - Cultura Material, p. 11-47, 1989.

BRAGANÇA, M. A tradução do Jeca Tatu por Mazzaropi: um caipira no descompasso do samba. Ipotesi, Juiz de Fora, v. 13, n. 1, p. 103-116, jan./jul., 2009.

BRANDÃO, C. R. O que é folclore. São Paulo: Brasiliense, 1982.

Os caipiras de São Paulo. São Paulo: Brasiliense, 1983.

CANCLINI, N. As culturas populares no capitalismo. São Paulo: Brasiliense, 1983.

CANDIDO, A. Os parceiros do Rio Bonito. 7. ed. São Paulo: Livraria Duas Cidades, 1987.

CARDOSO, R. Design, cultura material e o fetichismo dos objetos. Arcos, v. 1, 1998.

CARTA do Folclore Brasileiro. Publicada pela Comissão Nacional de Folclore, em dezembro de 1995. Disponível em: <http://www.fundaj.gov.br/geral/folclore/carta.pdf>. Acesso em: 15 nov. 2014.

CASCUDO, L. C. Dicionário do folclore brasileiro. 11. ed. São Paulo: Global, 1994.

CASTRO, V. S. Revisitando Amadeu Amaral. Estudos Lingüísticos XXXV, p. 1937-1944, 2006.

CENTRO DE PESQUISA E DOCUMENTAÇÃO DE HISTÓRIA CONTEMPORÂNEA DO BRASIL (CPDOC). História Oral. Fundação Getúlio Vargas. Disponível em: <http://cpdoc.fgv.br/acervo/historiaoral>. Acesso em: 24 jul. 2015.

CENTRO NACIONAL DE FOLCLORE E CULTURA POPULAR (CNFCP). Disponível em: <http://www.cnfcp.gov. br>. Acesso em: 2 jul. de 2013.

CHAUÍ, M. Conformismo e resistência, aspectos da cultura popular no Brasil. São Paulo: Brasiliense, 1986.

COPOS e jarro Marinha Grande. Up Magazine, TAP Portugal, 1 jul. 2009. Disponível em: <http://upmagazine-tap.com/pt_artigos/copos-e-jarro-marinha-grande>. Acesso em: (2 jul. 2014). 
CRISTOFARO, V. F. O design vernacular no comércio tradicional de Juiz de Fora. Disponível em: < http:// www.apesjf.org.br/comunicacao/artigos/design-vernacular-no-comercio-tradicional-de-juiz-de-fora>. Acesso em: 27 jun. 2013.

CSIKSZENTMIHALYI, M. Design and Order in Everyday Life. Design Issues, Cambridge, v. 8, n. 1, p. 26-34, outono, 1991. Disponível em: <http://www.jstor.org/stable/ 1511451>. Acesso em: 12 abr. 2013.

DAMAZIO, V. Artefatos de Memória da Vida Cotidiana: um olhar interdisciplinar sobre as coisas que fazem bem lembrar. Tese de Doutorado em Ciências Sociais - UERJ, Rio de Janeiro, 2005.

DE BONI, L. A. (Org.). A presença italiana no Brasil. Porto Alegre: EST, 1987.

DE QUEIROZ, M. I. P. Bairros rurais paulistas, dinâmica das relações bairro rural- cidade. São Paulo: Duas Cidades, 1973.

DONES, V. L. As apropriações do vernacular pela comunicação gráfica. NP 17 - Folkcomunicação, IV Encontro dos Núcleos de Pesquisa da Intercom, p. 2, 2004

DONDIS, D. A. Sintaxe da linguagem visual. São Paulo: Martins Fontes, 2007.

EGAS, O. Maurício Azeredo: uma obra sem avesso. São Paulo: Instituto Arte na Escola, 2005.

ESCOREL, A. L. O Efeito multiplicador do design. 1. ed. São Paulo: Senac, 2000.

EQUIPAMENTOS da Casa Brasileira: usos e costumes. Arquivo Ernani Silva Bruno. Disponível em: <http:// antigo.mcb.org.br/ernMain.asp>. Acesso em: 29 set. 2014.

FAUSTO, B. História concisa do Brasil. São Paulo: Edusp, 2008.

FERNANDES, F. O folclore em questão. São Paulo: Hucitec, 1989.

FINIZOLA, F. Tipografia vernacular urbana: uma análise dos letreiramentos populares. São Paulo: Blucher, 2010

Popular, regional, vernacular. In: CONSOLO, C (Org.). Anatomia do Design: Uma análise do design gráfico brasileiro. São Paulo: Blucher, 2009. p. 114-137.

FREITAS, S. M. E chegam os imigrantes... (o café e a imigração em São Paulo). São Paulo: Edição da autora, 1999.

FREITAS NETO, J. A. História geral e do Brasil. São Paulo: Harbra, 2011. 
FUCAPI - Fundação Centro de Análise, Pesquisa e Inovação Tecnológica. Disponível em: <http://www.fucapi.br/blog/2013/09/design-amazonico-ganha-premio-em-feira-internacional-na-franca/>. Acesso em: 3 ago. 2014.

GOLOVATY, R. V. Cultura popular: saberes e práticas de intelectuais, imprensa e devotos de Santos Reis, 1945-2002. Tese de Doutorado em História - Universidade Federal de Uberlândia, Uberlândia, 2005.

GOMES FILHO, J. Design do objeto: bases conceituais. São Paulo: Escrituras, 2006.

GONÇALVES, P. C. A cidade de São Paulo: um entreposto de braços para a lavoura cafeeira. Revista Cordis: Revista Eletrônica de História Social da Cidade, São Paulo, n. 2, 2009.

O "GRANDE AMIGO" Jeca Tatu. MAZZAROPI para mais cem anos, 22 out. 2012. Disponível em: <http:// www.centenariomazzaropi.org.br/o-grande-amigo-jeca-tatu/>. Acesso em: 8 nov. 2015.

HALBWACHS, M. A memória coletiva. São Paulo: Vértice; Editora Revista dos Tribunais, 1990.

HALL, S. A identidade cultural na pós-modernidade. 11. ed. Rio de Janeiro: DP\&A, 2000.

HOLLOWAY, T. H. Imigrantes para o café: café e sociedade em São Paulo 1886-1934. Rio de Janeiro: Paz \& Terra, 1984.

LÖBACH, B. Design industrial: bases para a configuração dos produtos industriais. São Paulo: Blucher, 2001.

LOBATO, M. Urupês. 37. reimp. ed revisada. São Paulo: Brasiliense, 1994.

Mr. Slang e o Brasil e Problema Vital. São Paulo: Brasiliense, 1964.

MAGALHÃES, A. O que o desenho industrial pode fazer pelo país? Arcos, v. 1, p. 8, 1998.

MARTINS, J. A sociabilidade do homem simples: cotidiano e história na modernidade anômala. São Paulo: Hucitec, 2000.

MENESES, U. T. B. Memória e Cultura material. Revista Estudos Históricos, v. 11, n. 21, Arquivos Pessoais, p. 89-103, 1998. Disponível em: <http://bibliotecadigital.fgv.br/ojs/index.php/reh/article/view/2067/1206>. Acesso em: 15 jul. 2007.

MONTEIRO, J. M. Negros da Terra. Índios e Bandeirantes nas origens de São Paulo, no séc. XVI. São Paulo: Companhia das Letras, 1999.

MORRIS, C. W. Foundations of the theory of signs. Chicago: The University of Chicago Press, 1970. 
MUSEU DA IMIGRAÇÃO DO ESTADO DE SÃO PAULO. Disponível em: <http://museudaimigracao.org.br>. Acesso em: 29 jul. 2014.

NEPOMUCENO, R. Música caipira: roça ao rodeio. São Paulo: Ed. 34, 1999.

NEVES, L. de A. Memória e História: potencialidades da História Oral. Revista ArtCultura, v. 5, n. 6, p. 2738, 2003.

NIEMEYER, L. Elementos de semiótica aplicados ao design. Rio de Janeiro: 2AB, 2003.

NORMAN, D. A. Design emocional: por que adoramos (ou detestamos) os objetos do dia-a-dia. Rio de Janeiro: Rocco, 2008.

NÖTH, W. Handbook of Semiotics. Bloomington, IN: Indiana University Press, 1995.

OLIVEIRA, L. L. O Brasil dos imigrantes. Rio de Janeiro: Jorge Zahar, 2001.

OLIVEIRA, R. S. Jeca Tatu: um personagem tipicamente brasileiro. Portal do Professor, 22 abr. 2011. Disponível em: <http://portaldoprofessor.mec.gov.br/fichaTecnicaAula.html?aula=31264>. Acesso em: 7 de junho de 2014.

ORTEGA, C. Lina Bo Bardi, móveis e interiores (1947-1968) interlocuções entre moderno e local. Tese de Doutorado para o Programa de Pós Graduação em Arquitetura e Urbanismo - Faculdade de Arquitetura e Urbanismo, Universidade de São Paulo, São Paulo, 2008.

ORTIZ, R. Cultura brasileira e identidade nacional. São Paulo: Brasiliense, 1985.

PARK, M. B. De Jeca Tatu a Zé Brasil: a possível cura da raça brasileira. Revista Sociedade e Agricultura, Rio de Janeiro, CPDA/UFRJ, v. 13, p. 143-150, out., 1999. Disponível em: < http://bibliotecavirtual.clacso.org. ar/ar/libros/brasil/cpda/estudos/treze/park13.htm>. Acesso em: 09 jul. 2015.

PIRES, C. Musa Caipira e As Estrambóticas Aventuras do Joaquim Bentinho. Tietê, SP: Prefeitura de Tietê, 1985.

POLLAK, M. Memória, Esquecimento, Silêncio. Estudos Históricos, Rio de Janeiro, v. 2, n. 3, 1989.

Memória e identidade social. Estudos Históricos, Rio de Janeiro, v. 5, n. 10, 1992.

PREFEITURA MUNICIPAL DE CAMPINAS. Campinas. Disponível em: <http://www.campinas.sp.gov.br/sobre-campinas/campinas.php>. Acesso em: 21 out. 2014. 
PROWN, J. D. The truth of material culture: history or fiction? In: LUBAR, Steven; KINGERY, W. David (Eds.) History from things: essays on material culture. Washington: Smithsonian: 1993. p. 1-19.

QUELUZ, M. L. P. (Org.). Design \& Identidade. Curitiba: Pelegrina, 2008.

REDIG, J. O mestre Aloísio Magalhães. Design \& Interiores, n. 12, p.70-76, jan./fev., 1989.

SAINT-HILAIRE, A. Viagem à província de S. Paulo. São Paulo: Livraria Martins; Edusp, 1972.

SANTOS, M. C. L. Spontaneous design, informal recycling and everyday life in postindustrial metropolis. Lecture presented at Conference Design plus Research, Politecnico di Milano, 2000.

SETUBAL, M. A. (Coord.) Modos de Vida dos paulistas: identidades, famílias e espaços domésticos. Centro de Estudos e Pesquisa em Educação, Cultura e Ação Comunitária. São Paulo: CENPEC; Imprensa Oficial do Estado de São Paulo, 2004.

SILVEIRA, V. Os caboclos, contos. 2. ed. Rio de Janeiro: Civilização Brasileira, 1975.

Leréias: histórias contadas por eles mesmos, contos. 2. ed. Rio de Janeiro: Civilização Brasileira, 1975.

Muxuangos, contos. 2. ed. Rio de Janeiro: Civilização Brasileira, 1975.

STOLCKE, V. A família que não é sagrada - Sistemas de trabalho e Estrutura familiar: o Caso das Fazendas do café em São Paulo. In: ARANTES, A. A. et al. Colcha de retalhos: estudo sobre a família no Brasil. Campinas: Unicamp, 1994. p. 72-79.

VASCONCELOS, H. D. Oscilações do movimento imigratório no Brasil. Revista de Imigração e Colonização, Rio de Janeiro, ano 1, n. 2, 1994.

SIMSON, O. R. M. V. Memória, cultura e poder na sociedade do esquecimento. Augusto Guzzo Revista Acadêmica, n. 6, p. 14-18, 2003. 
Apêndices e anexos 


\section{Apêndice A - Glossário visual popular paulista}

\section{Sumário do Apêndice A}

1. Arranjo com flor artificial, 160

2. Bacia de alumínio, 162

3. Bíblia, 164

4. Bule de café, 166

5. Calendário (folhinha), 168

6. Caneca de ágata, 170

7. Caneca de alumínio, 172

8. Caneca de louça de brinde de festa, 174

9. Canteiro com ervas e temperos, 176

10. Capa de botijão de gás, 178

11. Coador de café de pano, 180

12. Cobre-prateleira, 182

13. Cobre-talha, 184

14. Colcha e almofada de retalho, 186

15. Colcha de crochê, 188

16. Comigo-ninguém-pode, 190

17. Copo "bico de jaca", 192

18. Copo para café, 194

19. Cortina de renda, 196

20. Crucifixo, 198

21. Espelho de banheiro com moldura de plástico, 200

22. Ferro a carvão, 201

23. Filtro de água de barro (talha), 204

24. Fogão a lenha, 206

25. Gaiola com pássaro, 208

26. Galinho português de previsão do tempo, 210

27. Garrafa térmica com café, 212

28. Imagens de santos, 214

29. Jarra de leite, 216

30. Máquina de costura, 218

31. Moedor de café, 220

32. Moedor de carne, 222

33. Panela de ferro, 224

34. Paneleiro, 226

35. Pano de prato pintado à mão com bico de crochê, 228

36. Peneira para grãos, 230 
37. Pilão, 232

38. Porcelanas decoradas desparceiradas, 234

39. Potes de vidros decorados (bomboniere), 236

40. Prato de porcelana de enfeite, 238

41. Rádio, 240

42. Relicários (Oratórios) de santos, 242

43. Retratos antigos de parede, 244

44. Retratos de santos e de Cristo, 246

45. Roseira, 248

46. Samambaia suspensa, 250

47. Santa ceia, 252

48. Tacho de cobre, 254

49. Tapetinhos, 256

50. Toalha de plástico decorada, 258

51. Toalhinha de crochê, 260

52. Varal suspenso por bambu, 262

53. Vaso de porcelana decorado, 264

54. Vassoura de palha, 266 


\section{Lista de quadros do Apêndice $A$}

Quadro 1. Arranjos com flores artificiais presentes em residências de Rio Claro, Monte Aprazível, Piracicaba, Botucatu e Campinas. Intervenção de usuárias que misturam flores distintas e demais objetos, como laços de fitas e conchas, nos arranjos. Registros fotográficos da autora, 2014. (Sétimo arranjo, de cima para baixo e da esquerda para a direita: foto de Eliete Soares); 161

Quadro 2. Bacias de alumínio para uso na cozinha ou para a lavagem de roupa no quintal presentes em residências de Laranjal Paulista, Rio Claro, Monte Aprazível, Piracicaba, Botucatu, Limeira e Campinas. Registros fotográficos da autora, 2014. (Sétima e nona imagens, de cima para baixo e da esquerda para a direita: fotos de Eliete Soares); 163

Quadro 3. Bíblias para reza ou para enfeite presentes em residências de Laranjal Paulista, Rio Claro, Monte Aprazível, Piracicaba, Botucatu, Limeira, Campinas e São Luís do Paraitinga. Registros da autora, 2014. (Primeira e sétima imagens, de cima para baixo e da esquerda para a direita: fotos de Eliete Soares); 165

Quadro 4. Bules de café de louça, alumínio ou ágata, para uso ou enfeite, presentes em residências de São Luís do Paraitinga, Botucatu, Piracicaba, Laranjal Paulista, Monte Aprazível e Limeira. Registros fotográficos da autora, 2014. (Segunda e sexta imagens, de cima para baixo e da esquerda para a direita: fotos de Eliete Soares); 167

Quadro 5. Calendários ("folhinhas") penduradas na parede e atrás da porta da cozinha, muitas vezes sobrepostas, presentes em residências de São Luís do Paraitinga, Botucatu, Piracicaba, Laranjal Paulista, Campinas, Rio Claro, Monte Aprazível e Limeira. Registros fotográficos da autora, 2014. (Décima primeira imagem, de cima para baixo e da esquerda para a direita: foto de Eliete Soares); 169

Quadro 6. Caneca de ágata para café ou água presentes em residências de Botucatu, Piracicaba, Laranjal Paulista, Monte Aprazível e Campinas. Registros fotográficos da autora, 2014. (Primeira e quarta imagens, de cima para baixo e da esquerda para a direita: fotos de Eliete Soares); 171

Quadro 7. Canecas de alumínio para água presentes em residências de Laranjal Paulista, Botucatu, Piracicaba, Monte Aprazível, Piracicaba e Limeira. Registros fotográficos da autora, 2014. (Quarta imagem, de cima para baixo e da esquerda para a direita: foto de Eliete Soares); 173

Quadro 8. Caneca de louça de brinde de festa usado como porta lápis ou enfeite em residências de Laranjal Paulista, Piracicaba e Monte Aprazível. Registros fotográficos da autora, 2014. (Primeira imagem: foto de Eliete Soares); 175

Quadro 9. Canteiro, vasos, jardineiras ou mesmo uma bacia são utilizados para o cultivo de ervas e temperos, presentes em residências de Campinas, Piracicaba e Monte Aprazível. Registros fotográficos da autora, 2014; 177

Quadro 10. Capas de tecido reutilizado ou de crochê, produzidas pelas moradoras ou compradas escondem o botijão de gás nas residências de Piracicaba e Laranjal Paulista. Registros fotográficos da autora, $2014 ; 179$ 
Quadro 11. Coador de café de pano presentes em residências de Botucatu, Piracicaba, Laranjal Paulista, Monte Aprazível e Campinas. Registros fotográficos da autora, 2014. (Primeira e terceira imagem, de cima para baixo e da esquerda para a direita: fotos de Eliete Soares); 181

Quadro 12. Toalhinhas de crochê, guardanapos e cortes de plásticos cobrem as prateleiras de armários e paneleiros em residências de Monte Aprazível, Piracicaba, Botucatu e Laranjal Paulista. Registros fotográficos da autora, 2014. (Quinta, sexta e sétima imagens, de cima para baixo e da esquerda para a direita: fotos de Eliete Soares); 183

Quadro 13. Toalhinhas bordadas ou tecidas em crochê, compradas ou feitas pela moradora, cobrem a talha de barro em residências de São Luís do Paraitinga, Campinas, Botucatu, Piracicaba, Laranjal Paulista e Monte Aprazível. Registros fotográficos da autora, 2014. (Sétima e oitava imagens, de cima para baixo e da esquerda para a direita: fotos de Eliete Soares); 185

Quadro 14. Colchas e almofadas de retalhos, feitas pelas moradoras, presentes em residências de Botucatu, Laranjal Paulista e São Luís do Paraitinga. Registros fotográficos da autora, 2014. (Primeira, terceira e última imagens, de cima para baixo e da esquerda para a direita: fotos de Eliete Soares); 187

Quadro 15. Colchas de crochê presentes em residências de São Luís do Paraitinga, Piracicaba e Campinas. Orgulho das moradoras que produziram tal artefato trabalhoso. Registros fotográficos da autora, 2014; 189

Quadro 16. Para "espantar o mau-olhado", a planta comigo-ninguém-pode em vasos ou canteiros na entrada das residências em Rio Claro, Piracicaba, Monte Aprazível e Botucatu. Registros fotográficos da autora, 2014; 191

Quadro 17. Copos "bico de jaca" servem as visitas em residências de Rio Claro, Piracicaba e Monte Aprazível. Registros fotográficos da autora, 2014; 193

Quadro 18. Copos tipo americano para café presentes em residências de Campinas, Monte Aprazível, Piracicaba, Laranjal Paulista e Botucatu. Registros fotográficos da autora, 2014. (Última imagem: foto de Eliete Soares); 195

Quadro 19. Cortinas de renda com babados e pregas presentes em residências de São Luís do Paraitinga, Rio Claro, Piracicaba, Laranjal Paulista e Campinas. Registros fotográficos da autora, 2014; 197

Quadro 20. Crucifixos sobre os móveis ou na parede da sala abençoam o lar. De madeira, metal ou gesso, estão presentes em residências de Rio Claro, Piracicaba, São Luís de Paraitinga e Campinas. Notam-se, na primeira e terceira imagens ao alto, folhas secas de palmeira recebidas na celebração do Dia de Ramos. Registros fotográficos da autora, 2014; 199

Quadro 21. Espelhinhos de banheiro com moldura de plástico cor de abóbora presentes em residências de Laranjal Paulista, Botucatu e Limeira. Registros fotográficos da autora, 2014. (Duas primeiras imagens: fotos de Eliete Soares); 201

Quadro 22. Ferros a carvão guardados como relíquia enfeitam residências de Piracicaba e Botucatu. Registros fotográficos da autora, 2014. (Primeira imagem acima à esquerda: foto de Eliete Soares); 203 
Quadro 23. Filtro de água de barro (talha) sobre a pia da cozinha garante água fresca nas residências de Campinas, Laranjal Paulista, Rio Claro, Piracicaba, Botucatu, Limeira e São Luís do Paraitinga. Registros fotográficos da autora, 2014. (Oitava e nona imagem, de cima para baixo e da esquerda para a direita: fotos de Eliete Soares); 205

Quadro 24. Fogão a lenha, no sítio ou na cidade, para o preparo das refeições diárias. Presentes em residências de Laranjal Paulista, Rio Claro, Botucatu e Limeira. Registros da autora, 2014. (Segunda, terceira e quinta imagens, de cima para baixo e da esquerda para a direita: fotos de Eliete Soares); 207

Quadro 25. Gaiola com pássaros - canário, calopsita e papagaio. Hábito presente em residências de Laranjal Paulista e Piracicaba. Registros fotográficos da autora, 2014; 209

Quadro 26. Galinho português que faz a previsão do tempo e muda de cor presente em residências de Laranjal Paulista e Piracicaba. Registros fotográficos da autora, 2014; 211

Quadro 27. Garrafas térmicas com café repousam sobre a mesa ou a pia da cozinha em residências de Rio Claro, Laranjal Paulista, Monte Aprazível, Piracicaba, Botucatu, Limeira, Campinas e São Luís do Paraitinga. Registros fotográficos da autora, 2014. (Segunda imagem, de cima para baixo e da esquerda para a direita: foto de Eliete Soares); 213

Quadro 28. Imagens de santos em pequenos altares domésticos presentes em residências em Laranjal Paulista, Rio Claro, Monte Aprazível, Piracicaba, Botucatu, Limeira, Campinas e São Luís do Paraitinga. Registros fotográficos da autora, 2014; 215

Quadro 29. Jarras de leite fora de uso, guardadas nos armários ou usadas como enfeite, presentes em residências em Piracicaba, Botucatu e Limeira. Registros fotográficos da autora, 2014; 217

Quadro 30. Máquinas de costura em uso pelas moradoras de Laranjal Paulista, Monte Aprazível, Piracicaba, Botucatu, Limeira, Campinas e São Luís do Paraitinga. Registros fotográficos da autora, 2014; 219

Quadro 31. Moedor de café, para uso ou para enfeite, presentes em residências de Monte Aprazível, Piracicaba, Botucatu, Limeira. Registros fotográficos da autora, 2014; 221

Quadro 32. Moedor de carne, para uso na produção de linguiça ou para enfeite, presentes em residências de Monte Aprazível, Piracicaba, Botucatu. Registros fotográficos da autora, 2014; 223

Quadro 33. Panela de ferro em uso nas residências de Laranjal Paulista, Botucatu, Limeira e Campinas. Registros fotográficos da autora, 2014. (Terceira e sétima imagens, de cima para baixo e da esquerda para a direita: fotos de Eliete Soares); 225

Quadro 34. Paneleiros e tampeiros organizam panelas e tampas de alumínio cuidadosamente areadas. Presentes em residências de Laranjal Paulista, Piracicaba e Botucatu. Registros fotográficos da autora, 2014. (Primeira, segunda, quarta e última imagem, de cima para baixo e da esquerda para a direita: fotos de Eliete Soares); 227

Quadro 35. Panos de prato, pintados e bordados à mão com acabamentos do tipo "bico de crochê", cobrem geladeiras e fogões, além de seu uso funcional. Presentes em residências de Campinas, Rio Claro, Monte Aprazível, Laranjal Paulista, Limeira, Piracicaba e Botucatu. Registros da autora, 2014; 229 
Quadro 36. Peneiras rústicas, para peneirar grãos como café e milho, presentes em residências de Laranjal Paulista, Monte Aprazível, Limeira e Botucatu. Registros fotográficos da autora, 2014. (Primeira imagem, de cima para baixo: foto de Eliete Soares); 231

Quadro 37. Pilões de madeira, em uso e como enfeite, presentes em residências de Laranjal Paulista, Piracicaba e Botucatu. Registros fotográficos da autora, 2014. (Primeira, segunda e quarta imagens, de cima para baixo e da esquerda para a direita: fotos de Eliete Soares); 233

Quadro 38. Porcelanas decoradas "desparceiradas" em uso em residências de Limeira, Laranjal Paulista, Monte Aprazível, Campinas, Piracicaba e Botucatu. Registros fotográficos da autora, 2014; 235

Quadro 39. Potes de vidro decorados (bombonière) contêm balas, bombons e outras guloseimas, especialmente para os netos. Presentes em residências de Laranjal Paulista, Piracicaba, São Luís do Paraitinga, Campinas, Rio Claro e Botucatu. Registros fotográficos da autora, 2014; 237

Quadro 40. Pratos de porcelana enfeitam paredes e móveis em suportes e sobre as prateleiras. Presentes em residências de Piracicaba, Campinas e São Luís do Paraitinga. Registros da autora, 2014; 239

Quadro 41. O rádio faz companhia para a dona de casa. Presentes em residências de Laranjal Paulista, Piracicaba, Limeira e Botucatu. Registros fotográficos da autora, 2014. (Primeira imagem de cima para baixo: foto de Eliete Soares); 241

Quadro 42. Relicários ou oratórios com imagens de santos confirmam a religiosidade doméstica. Presentes em residências de Laranjal Paulista, Monte Aprazível, São Luís do Paraitinga, Piracicaba e Botucatu. Na segunda imagem, de cima para baixo e da esquerda para a direita, nota-se a peça em forma de capela feita com embalagens de maços de cigarro pintados de branco. Registros fotográficos da autora, 2014. (Última imagem, de cima para baixo e da esquerda para a direita: foto de Eliete Soares); 243

Quadro 43. Retratos antigos de parede - tradição e homenagem aos antepassados. Presentes em residências de Laranjal Paulista, Rio Claro, Monte Aprazível, Campinas, São Luís do Paraitinga, Piracicaba e Botucatu. Registros fotográficos da autora, 2014; 245

Quadro 44. Retratos de santos e de Cristo abençoam o lar. Presentes em residências de Campinas, Limeira, Laranjal Paulista, Monte Aprazível, São Luís do Paraitinga, Piracicaba e Botucatu. Na última imagem, de cima para baixo e da esquerda para a direita, notam-se dois quadros iguais na parede da residência em Laranjal Paulista (Foto de Eliete Soares). Demais imagens, registros fotográficos da autora, 2014; 247

Quadro 45. Roseiras carregadas de flores são o orgulho das moradoras. Encontradas em residências de Laranjal Paulista, Monte Aprazível, São Luís do Paraitinga e Piracicaba. Registros fotográficos da autora, 2014; 249

Quadro 46. Diferentes variedades de samambaias, suspensas em vasos e xaxins, pendurados nas varandas e garagens. Presentes em residências de Monte Aprazível, São Luís do Paraitinga, Piracicaba e Botucatu. Registros fotográficos da autora, 2014; 251

Quadro 47. Santa Ceia abençoa os lares em Botucatu, Laranjal Paulista, Monte Aprazível e Rio Claro. Registros fotográficos da autora, 2014. (Última imagem em baixo: foto de Eliete Soares); 253

Quadro 48. Tacho de cobre para produção de sabão e doces. Presentes em residências de Laranjal Paulista, Monte Aprazível, Campinas, Piracicaba e Botucatu. Registros fotográficos da autora, 2014; 255 
Quadro 49. Tapetinhos de crochê ou de retalhos protegem os pés da friagem e emolduram os móveis. Presentes em residências de Laranjal Paulista, Monte Aprazível, Campinas, Piracicaba e Botucatu. Registros fotográficos da autora, 2014. (Terceira imagem, de cima para baixo e da esquerda para a direita: foto de Eliete Soares); 257

Quadro 50. Toalhas de plástico decoradas, em sua maioria com motivos florais, cobrem as mesas da cozinha em residências de Laranjal Paulista, Monte Aprazível, Limeira, Campinas, Piracicaba e Botucatu. Registros fotográficos da autora, 2014; 259

Quadro 51. Toalhinhas de crochê cobrem móveis, protegem objetos e enfeitam as casas. Presentes em Campinas, Rio Claro, Laranjal Paulista, Monte Aprazível, São Luís do Paraitinga e Piracicaba. Registros fotográficos da autora, 2014; 261

Quadro 52. Varal suspenso por bambu - solução inteligente para aproveitamento do espaço. Presentes em residências de Botucatu, Rio Claro, Laranjal Paulista, Monte Aprazível e Piracicaba. Registros fotográficos da autora, 2014; 263

Quadro 53. Vasos de porcelana doméstica decorados com motivos florais. Presentes em residências de Botucatu, Laranjal Paulista, Monte Aprazível, Rio Claro, Campinas e Piracicaba. Registros fotográficos da autora, 2014; 265

Quadro 54. Vassouras de palha em diferentes estágios de sua vida útil, algumas com a base arredondada bem desgastada pelo uso. Na sexta imagem, de cima para baixo e da esquerda para a direita, vêm-se três vassouras novas guardadas. Na última foto, em baixo e à direita, vê-se a produção de vassouras em sítio de Limeira. Também presentes em residências de Monte Aprazível, Laranjal Paulista, São Luís do Paraitinga, Piracicaba, Campinas e Botucatu. Registros fotográficos da autora, 2014; 267 
As imagens e as descrições a seguir compõem o que chamamos de Glossário visual popular paulista. Para cada artefato memorável e notável, foram elaborados quadros de imagens daqueles exemplares encontrados em campo, de forma a evidenciar seus aspectos formais ou mesmo alguma particularidade quanto ao seu uso ou à disposição destes nos ambientes onde foram localizados.

A quantidade de imagens constantes em cada quadro corresponde à ocorrência do mesmo na pesquisa de campo. A elas, foram acrescentadas breves descrições destes artefatos, do ponto de vista de sua materialidade, seus aspectos sintáticos e semânticos, algumas características de uso e de disposição no ambiente, além de citações de usuários entrevistados.

Resultante deste estudo, o glossário destina-se à consulta e à referência por designers com interesse na identidade regional paulista do artefato doméstico popular. 


\section{Arranjo com flores artificiais}

Os arranjos com flores artificiais aparecem em vasos de porcelana, cachepots ou cestos em todos os ambientes da casa, mas são mais frequentemente encontrados em mesas laterais ou estantes da sala, sobre toalhinhas de crochê, dispostos com a intenção de enfeitar o ambiente. Também aparecem junto a imagens de santos em pequenos altares como forma de oferenda.

Os arranjos são normalmente elaborados pelas moradoras, que compram pequenos ramalhetes de diferentes tipos de flores para compor o seu próprio buquê. Trata-se de um artigo de baixo custo, facilmente encontrado em estabelecimentos comerciais conhecidos como "lojas de 1,99".

Não respeitam necessariamente critérios de harmonia na escolha das flores, em relação às cores ou tipologia, o que resulta em arranjos extremamente originais como rosas vermelhas junto a girassóis amarelos. Um detalhe interessante diz respeito à originalidade dos arranjos: em alguns deles, além das flores, há pequenos objetos inseridos pelas moradoras como laços de fita, conchas e outros bibelôs como um coração aveludado com texto dourado em relevo. Em menor número, encontramos arranjos prontos originais que a moradora ganhou de presente e que não sofreram nenhum tipo de customização. 


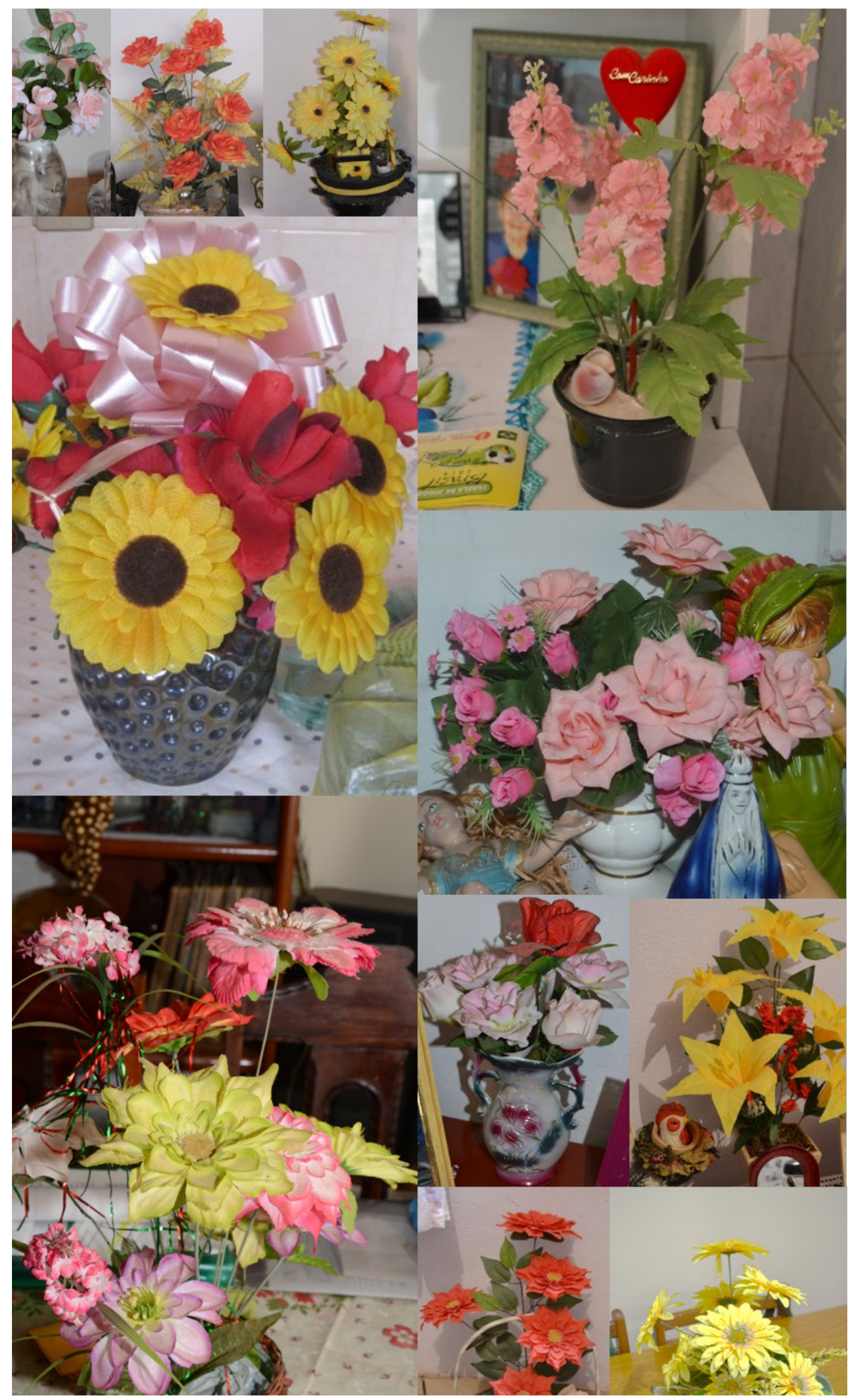




\section{Bacia de alumínio}

Bacias de alumínio geralmente são utilizadas para lavar roupas, mas também foram encontradas na cozinha, onde são usadas para preparo de alimentos.

Seu valor reside em aspectos funcionais relativos ao seu material, o alumínio: além de mais duradoura do que a bacia de plástico, a bacia de alumínio desempenha um papel importante na qualidade da lavagem da roupa branca. É usada para o que se chama de quarar a roupa: colocam-se peças de roupa branca com sabão e pouca água na bacia ao sol. O alumínio esquenta a água, o que faz com que a roupa fique mais branca.

Quando utilizada na cozinha, em comparação à bacia de plástico, é considerada superior por ser feita de material percebido como mais higiênico, que se pode arear.

Também é utilizada para dar banho em crianças, com água amornada no fogão a lenha.

Por serem muito duráveis, encontramos alguns casos onde as bacias da residência foram herdadas da mãe.

Quadro 2. Bacias de alumínio para uso na cozinha ou para a lavagem de roupa no quintal presentes em residências de Laranjal Paulista, Rio Claro, Monte Aprazível, Piracicaba, Botucatu, Limeira e Campinas. Registros fotográficos da autora, 2014. (Sétima e nona imagens, de cima para baixo e da esquerda para a direita: fotos de Eliete Soares)

1 Informação verbal fornecida por Simson em São Paulo, em 2014. 


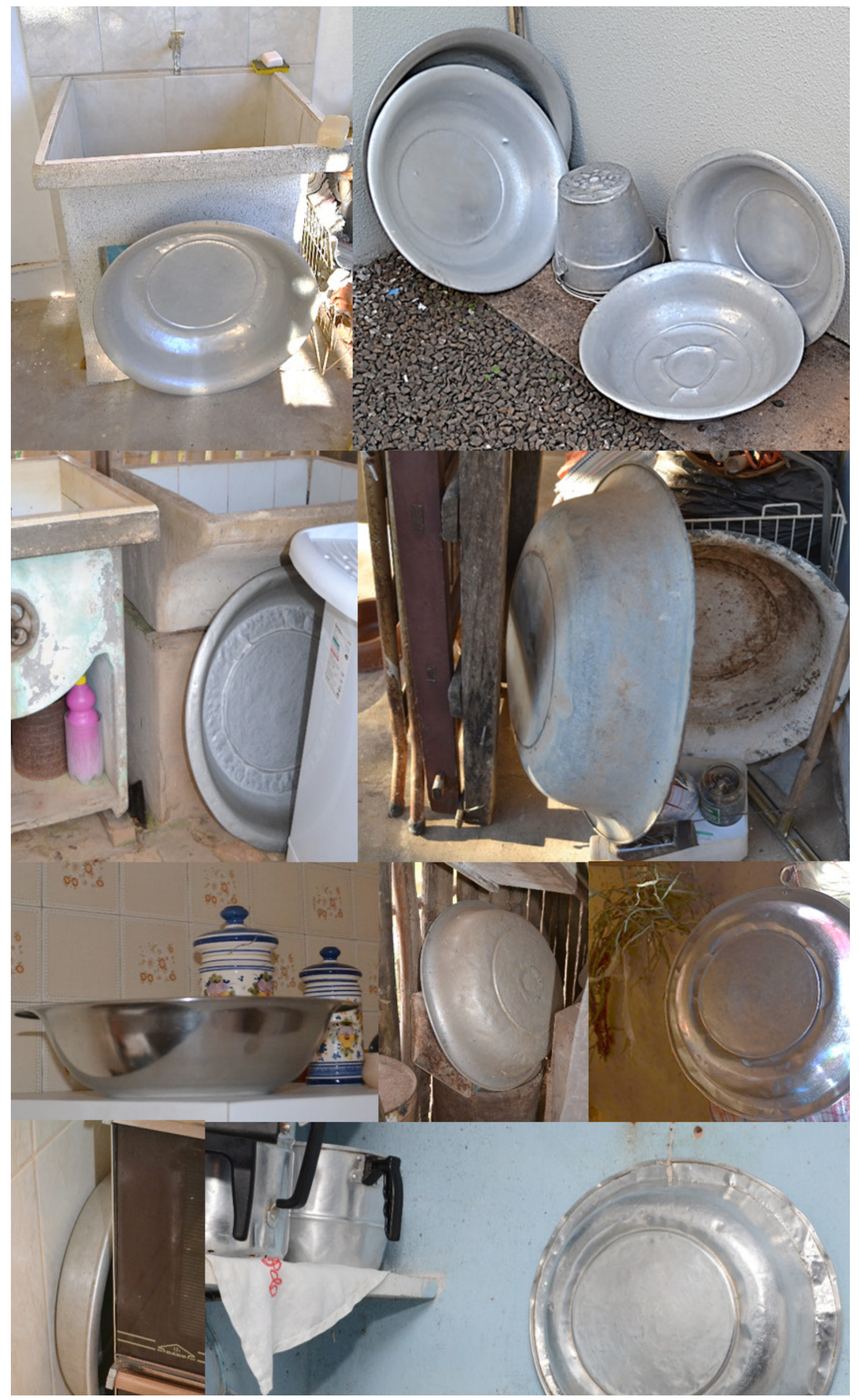




\section{Bíblia}

A bíblia está presente tanto em residências de católicos quanto de evangélicos, os dois maiores grupos religiosos do Brasil. No caso destes, a bíblia é levada ao culto semanal, portanto, costuma ser uma edição menor, mais leve, que geralmente fica fechada e apoiada sobre um móvel da sala ou do quarto.

Já na casa de vários católicos entrevistados, ela aparece aberta, junto à imagem de um santo de devoção, na página em que se encontra a oração a ser lida no dia.

Em algumas residências, ela fica exposta aberta, apoiada num suporte de madeira ou metal sobre um móvel, como uma cômoda de quarto ou aparador da sala de jantar. É um símbolo de devoção que também opera como enfeite. 

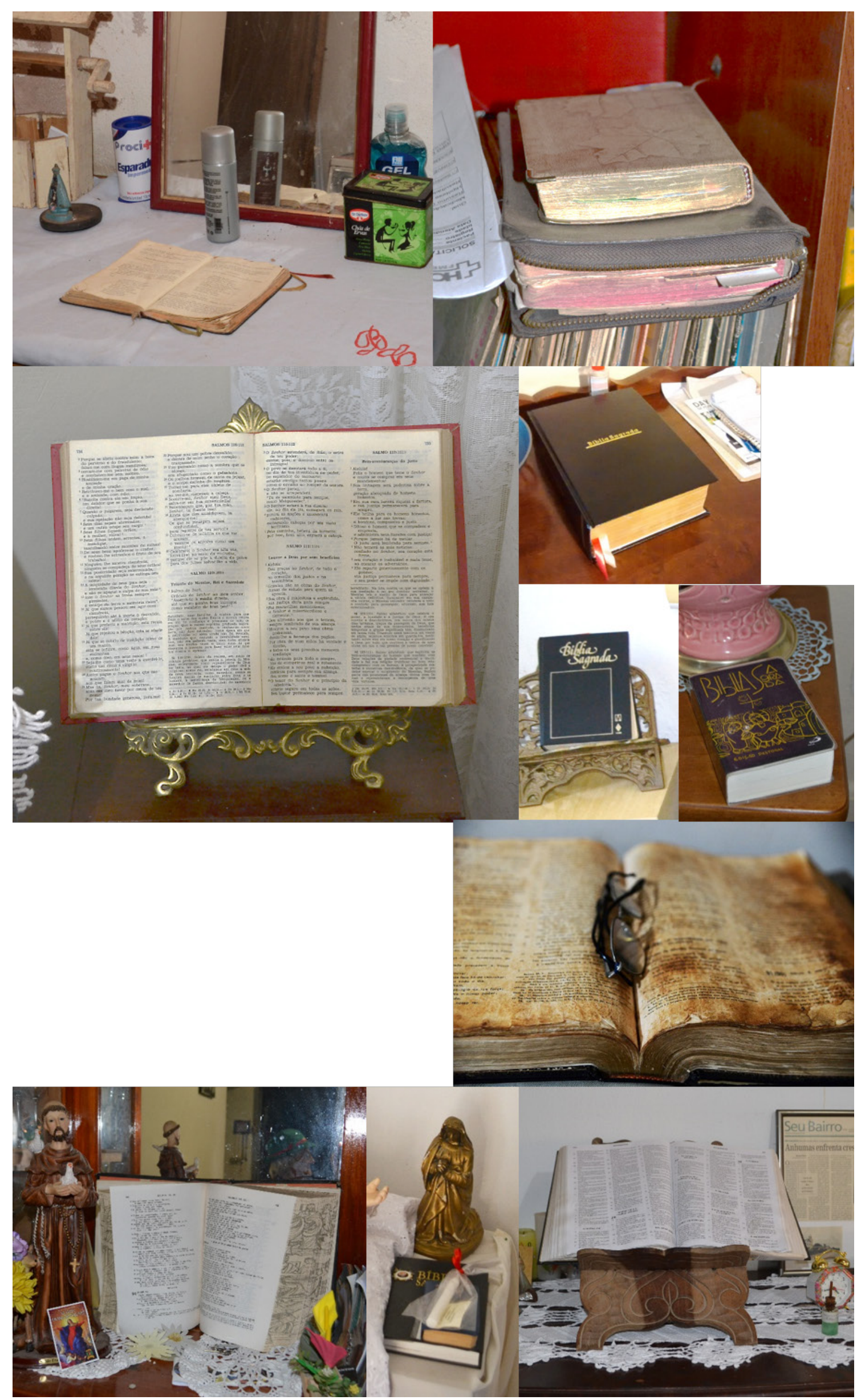


\section{Bule de café}

O bule serve tanto para preparar quanto para servir o café, havendo uma distinção relativa ao seu uso e ao material de que é feito.

Os bules de alumínio são utilizados no preparo do café, geralmente com coador de pano e seu suporte. Nele, o café é passado diretamente e, em seguida, é colocado na garrafa térmica, para então ser servido.

Já o bule de porcelana é um objeto que faz parte do jogo de louça e, frequentemente, acompanha xícaras e pires com motivos combinados para que se sirva o café ao consumo. Porém, nas residências onde foi encontrado, o bule de porcelana já está "desparceirado" de seu jogo, não é mais utilizado e o café é servido na garrafa térmica. Nestes casos, ele fica solitário sobre a estante da sala de jantar e sua função é enfeitar, além de representar certo status, já que ter tido um jogo de louça completo é um privilégio de pessoas com maior poder socioeconômico.

Em apenas uma ocorrência, encontramos um bule de ágata que também não desempenha mais sua função utilitária, servindo de enfeite e relíquia para os moradores. 


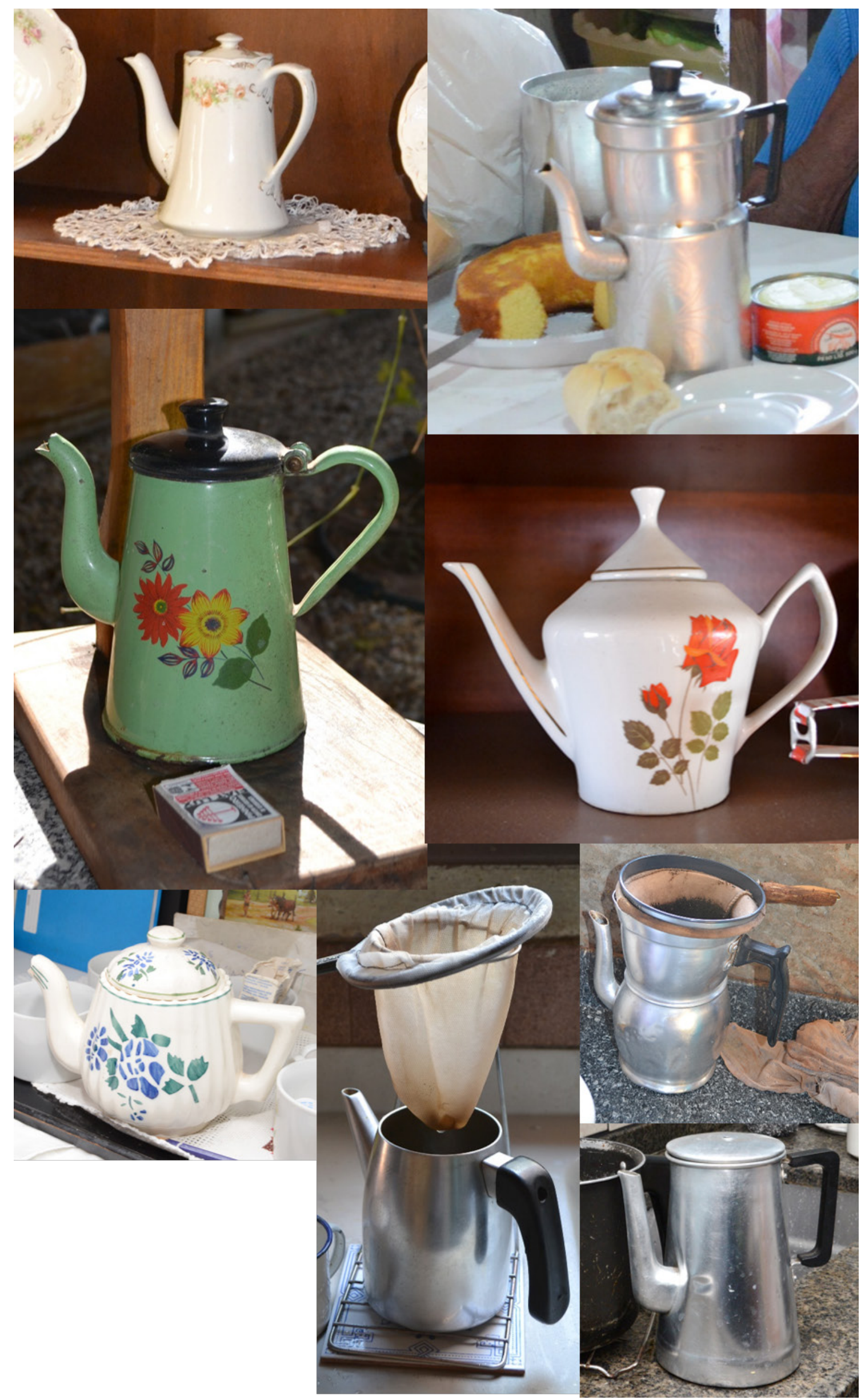




\section{Calendário (folhinha)}

O calendário impresso é comumente chamado de folhinha. O artefato, presente em várias residências visitadas, aparece pendurado em salas e cozinhas, tanto na parede principal do cômodo - como se fosse um quadro, claramente com a intenção de enfeitar - quanto pendurado em algum prego existente. Neste último caso, não há critério aparente de disposição e nem sempre o local é o mais apropriado: pode ser em um batente, por exemplo, o que faz com que parte da folhinha fique no vão da porta. Outro local onde se costuma pendurá-lo é atrás da porta da cozinha.

Em todos os casos, os moradores relataram ter ganho a folhinha de algum comércio ou entidade local.

Em várias residências, foram encontradas mais de uma folhinha num mesmo ambiente, muitas vezes sobrepostas. Por que tantos calendários? As respostas se dividem em dois grupos: de um lado, aqueles que guardam as folhinhas recebidas em sinal de consideração a quem as thes deu ("Ah, a gente ganha de gente conhecida aqui do comércio e fica com dó de jogar fora"); por outro, há os que expõem a folhinha na parede em local visível por causa da imagem ou de alguma citação contida na peça. O último caso está frequentemente associado ao caráter religioso das imagens de santos e citações bíblicas: "Essa aqui eu gosto por causa da foto e dos dizeres... é do ano passado, mas eu não joguei fora" - disse uma das entrevistadas, referindo-se à imagem do Sagrado Coração de Jesus com uma citação.

A origem do termo "folhinha" está ligada a um modelo de calendário de parede, do qual se retira uma pequena folha por dia de um pequeno bloco. Tais blocos frequentemente localizam-se ao pé de uma estampa e, em cada folha, há uma oração ou ensinamento moral, assim como a menção ao Santo do Dia².

Quadro 5. Calendários ("folhinhas") penduradas na parede e atrás da porta da cozinha, muitas vezes sobrepostas, presentes em residências de São Luís do Paraitinga, Botucatu, Piracicaba, Laranjal Paulista, Campinas, Rio Claro, Monte Aprazível e Limeira. Registros fotográficos da autora, 2014. (Décima primeira imagem, de cima para baixo e da esquerda para a direita: foto de 


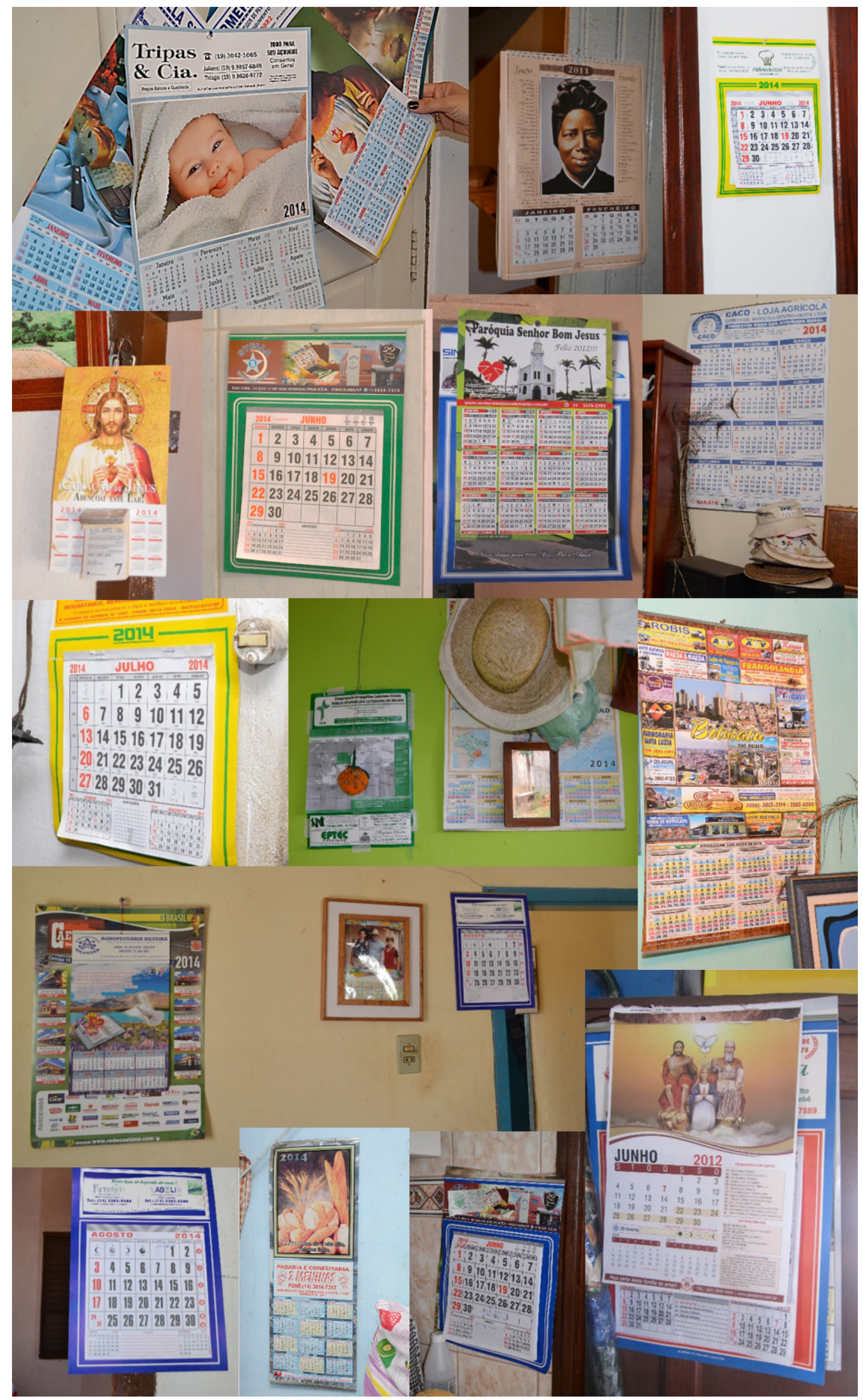




\section{Caneca de ágata}

A caneca de ágata é uma peça solitária. Utilizada para tomar café, geralmente é branca com a borda preta e, em alguns casos, apresenta uma estampa única em motivo floral.

A ágata é um banho de esmalte cerâmico sobre uma peça de ferro, acabamento muito utilizado em utensílios domésticos desde o período colonial. Foi pouco encontrada nas residências visitadas, ficando praticamente restrita à caneca (com exceção de um bule e um penico encontrados no quintal de uma residência, transformados em vasos de plantas). 


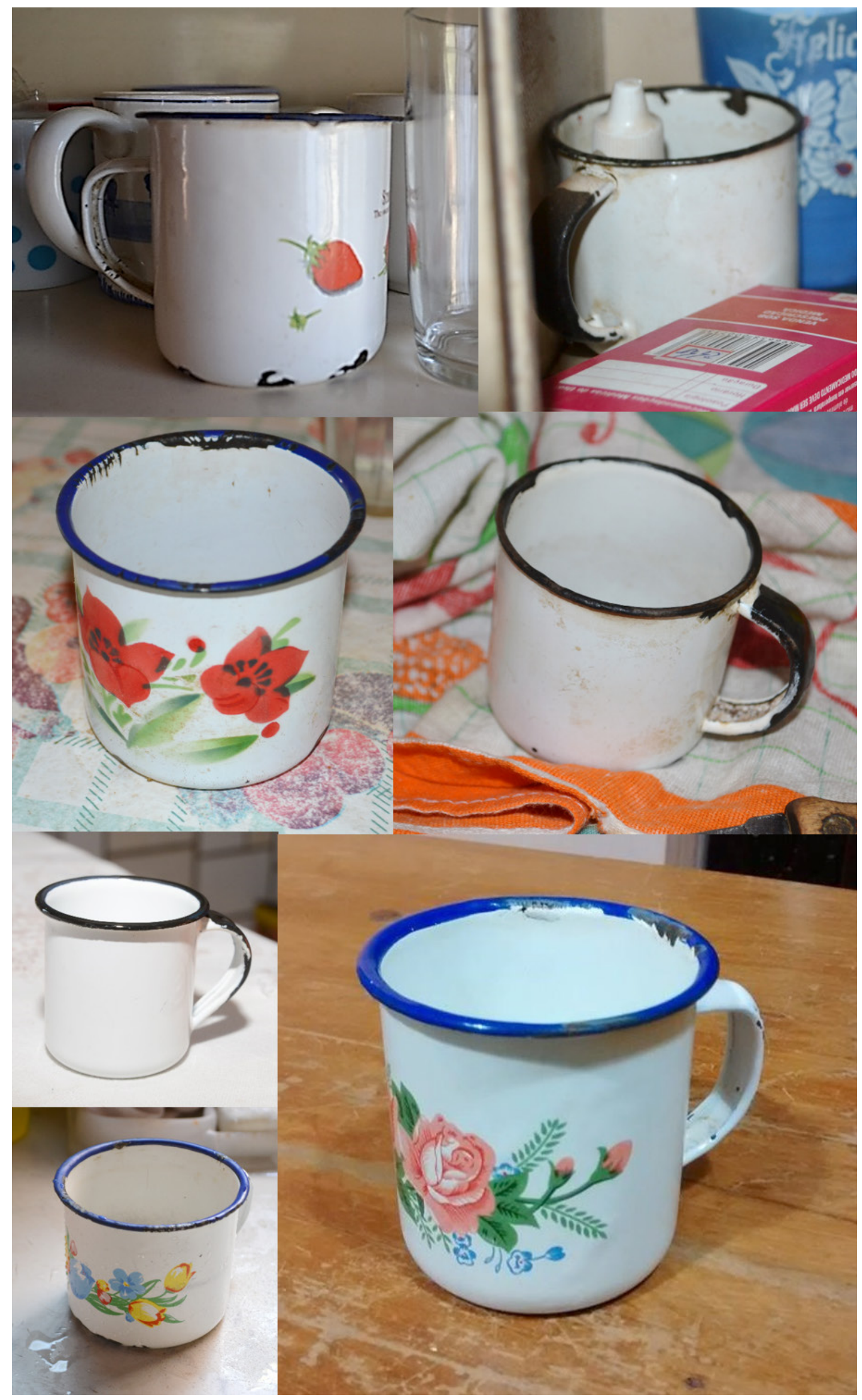




\section{Caneca de alumínio}

A caneca de alumínio é utilizada prioritariamente para beber água. É um objeto simples, barato e extremamente durável, preferido em relação ao copo de vidro por ser inquebrável. Fácil de manter, a caneca de alumínio pode ser areada com palha de aço, o que ressalta seu aspecto higiênico mesmo que esteja amassada pelo uso, já que o alumínio é um metal mole e a parede da caneca não é espessa.

Aparece várias vezes pendurada pela alça, próxima à talha.

Encontramos algumas ocorrências da caneca de alumínio como brinde de empresas. Neste caso, o logotipo ou algum outro dado da empresa aparecem impressos na face externa da caneca. Por duas vezes, pudemos observar, no metal, a gravação de desenhos com efeito decorativo. 


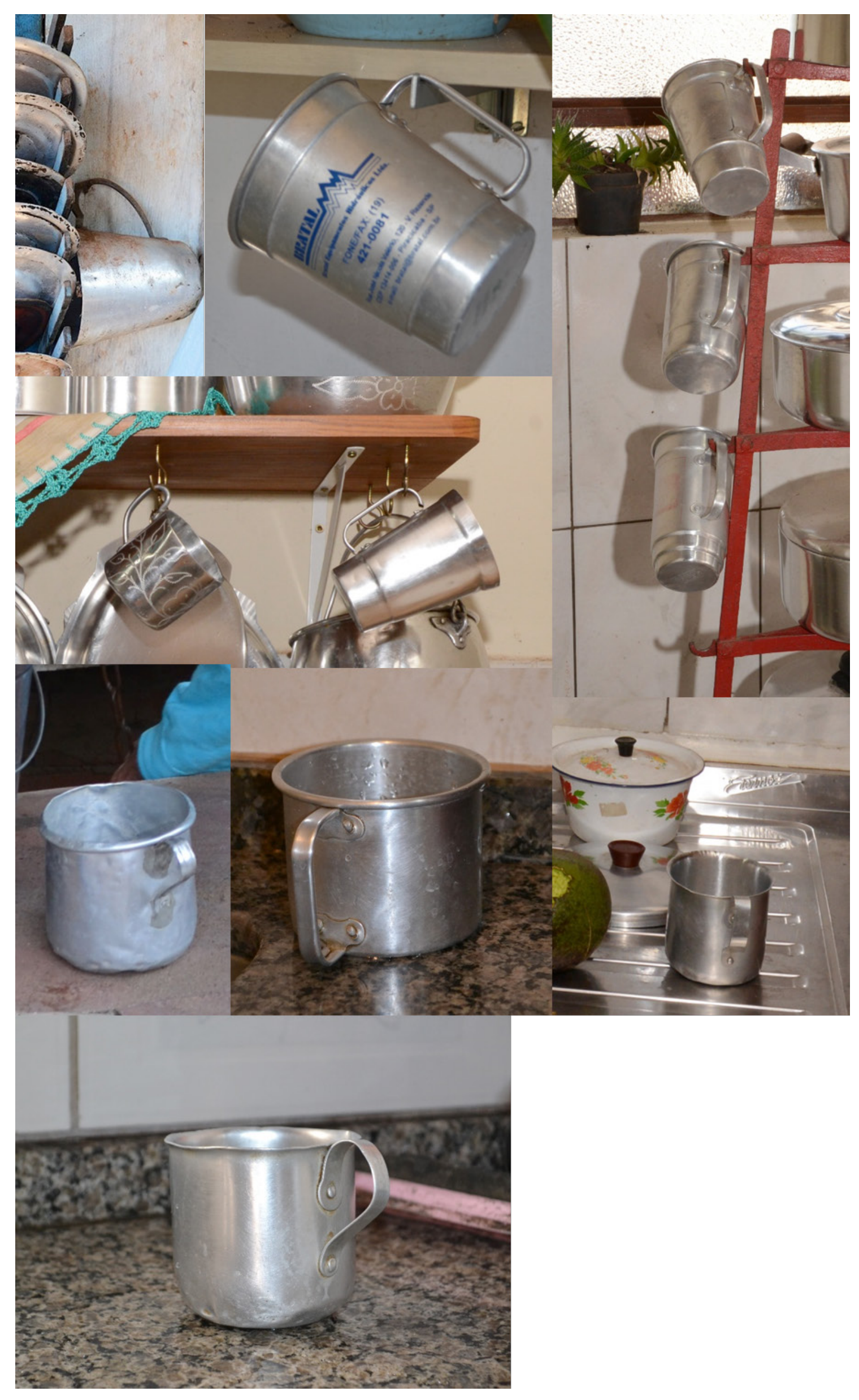




\section{Caneca de louça de brinde de festa}

As canecas de louça de brinde de festa têm algumas particularidades: são artefatos obtidos como brindes em ocasiões comemorativas (festas, celebrações de datas); são grandes e pesadas, pois a porcelana de que são feitas é um material frágil e necessita de uma parede espessa para garantir sua resistência; têm detalhes formais clássicos como arabescos e volutas, originais do próprio molde com o qual são produzidas, deixando uma área lisa no centro para a aplicação de uma estampa; apresentam uma pintura de fundo, normalmente com efeitos de dégradée; e, na área lisa do molde, são decoradas com o tema da festa, com a aplicação de decalque identificando o evento (logotipo, títulos, datas).

Ficam expostas em estantes na sala ou na cozinha, como enfeite ou relíquia, e podem ser reutilizadas como porta-lápis, por exemplo. Raramente são usadas como caneca novamente - por serem pesadas e frágeis, são consideradas pouco funcionais. 


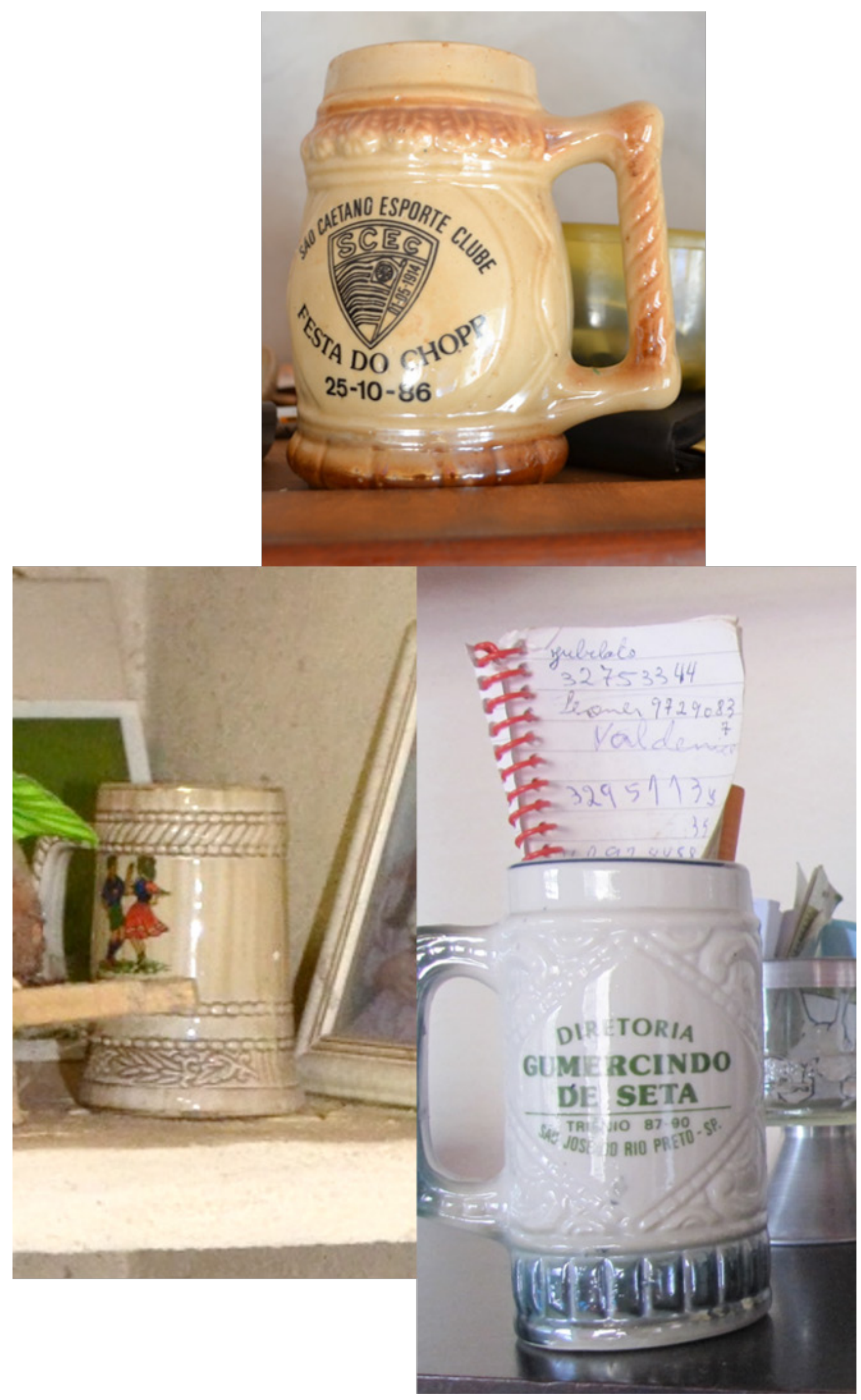




\section{Canteiro com ervas e temperos}

Os canteiros encontrados apresentam plantas para consumo e preparos de chás, temperos (salsa, cebolinha, hortelã, manjericão, erva-cidreira, boldo, entre outros) e algumas poucas hortaliças (couve, almeirão). Localizam-se tanto na frente quanto nos fundos das casas, muitas vezes em vasos, bacias e jardineiras, e são mantidos pelos próprios moradores.

Estão associados a um saber popular, pois muitas dessas plantas têm função medicinal: chá de boldo para problemas no fígado e má digestão, por exemplo.

Podem ser vinculados à herança rural desta população, acostumada com "a lida na roça" e com a autossuficiência da unidade familiar, resquícios dos bairros rurais com habitações distantes dos centros (vilas e cidades), onde se encontram serviços de saúde e farmácias. 


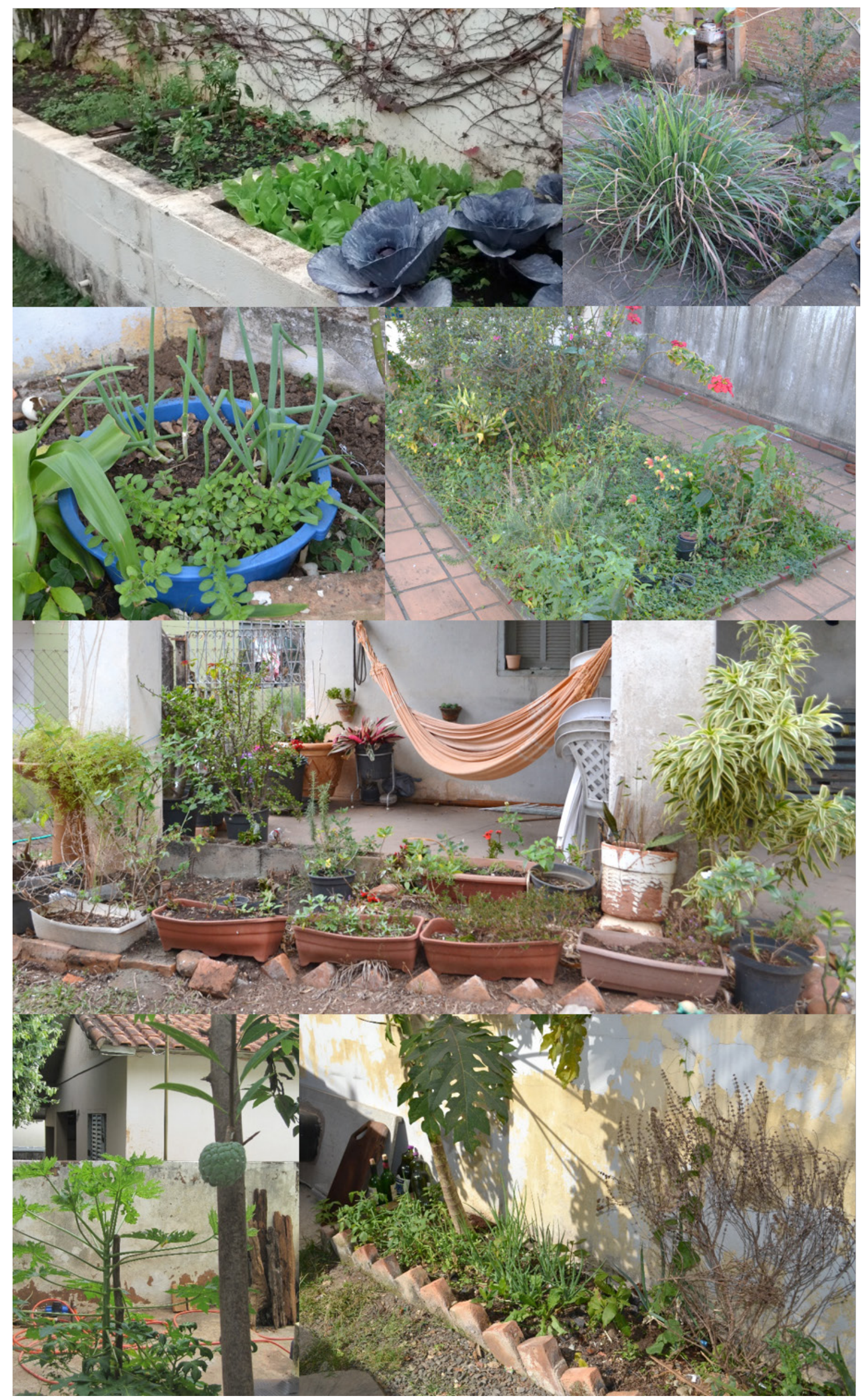




\section{Capa de botijão de gás}

A capa para o botijão de gás tem a função de escondê-lo, ou melhor, de disfarçá-lo. São encontradas em residências nas quais gás fica dentro da cozinha, ao lado do fogão. Por ser considerado um objeto feio e bruto, o botijão ganha uma capa para cobri-lo.

Das amostras encontradas, uma é de crochê de fio de algodão e foi comprada em um bazar; outra, é de tecido com aplique bordado e foi comprada em uma loja de artigos para a casa; uma terceira, foi feita pela dona da casa a partir de uma cortininha de renda de cozinha; a quarta, é na verdade um vestido de festa junina. Esta última peça pertencia a uma das netas da moradora e, uma vez que já não cabia mais na criança, foi transformada em capa para o botijão pois, de acordo com ela, "era bonitinho, com babados, achei que combinava." 


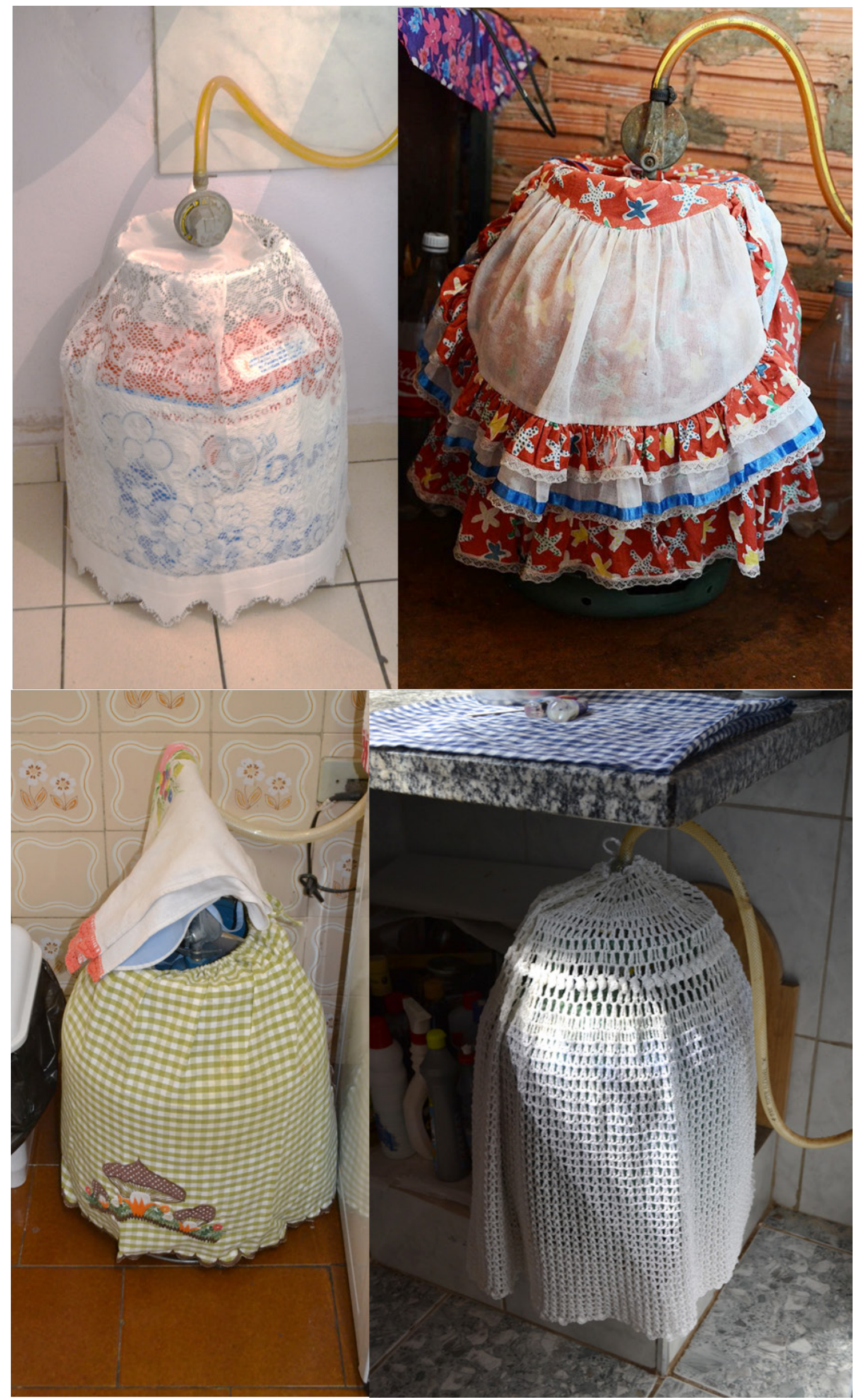




\section{Coador de café de pano}

O coador de café de pano é um utensílio bastante utilizado pela população entrevistada e seu uso está relacionado tanto à questão do costume quanto à de economia, ou de sabor: "café coado no coador de pano é mais gostoso!" Vários entrevistados relataram que utilizam o coador de pano porque estão acostumados, mas, quando aprofundamos a questão, alegam também o fato de ser mais econômico que o coador de papel descartável.

O coador é comprado em mercados, mas, depois de muito uso, seu tecido de algodão tende a furar, o que demanda um coador novo ou a troca de, ao menos, parte do tecido. Em algumas residências, pudemos notar coadores com o tecido feito pela moradora, em algodão estampado, inclusive, pois era o que havia disponível. A armação de metal, nestes casos, é reutilizada.

Algumas vezes, usa-se o coador apoiado num suporte de metal, sobre o bule, mas também é comum segurá-lo enquanto a água é despejada sobre o pó de café.

Em várias residências visitadas, a moradora fez questão de passar um café para a pesquisadora, utilizando o coador de pano, sinal de hospitalidade. 


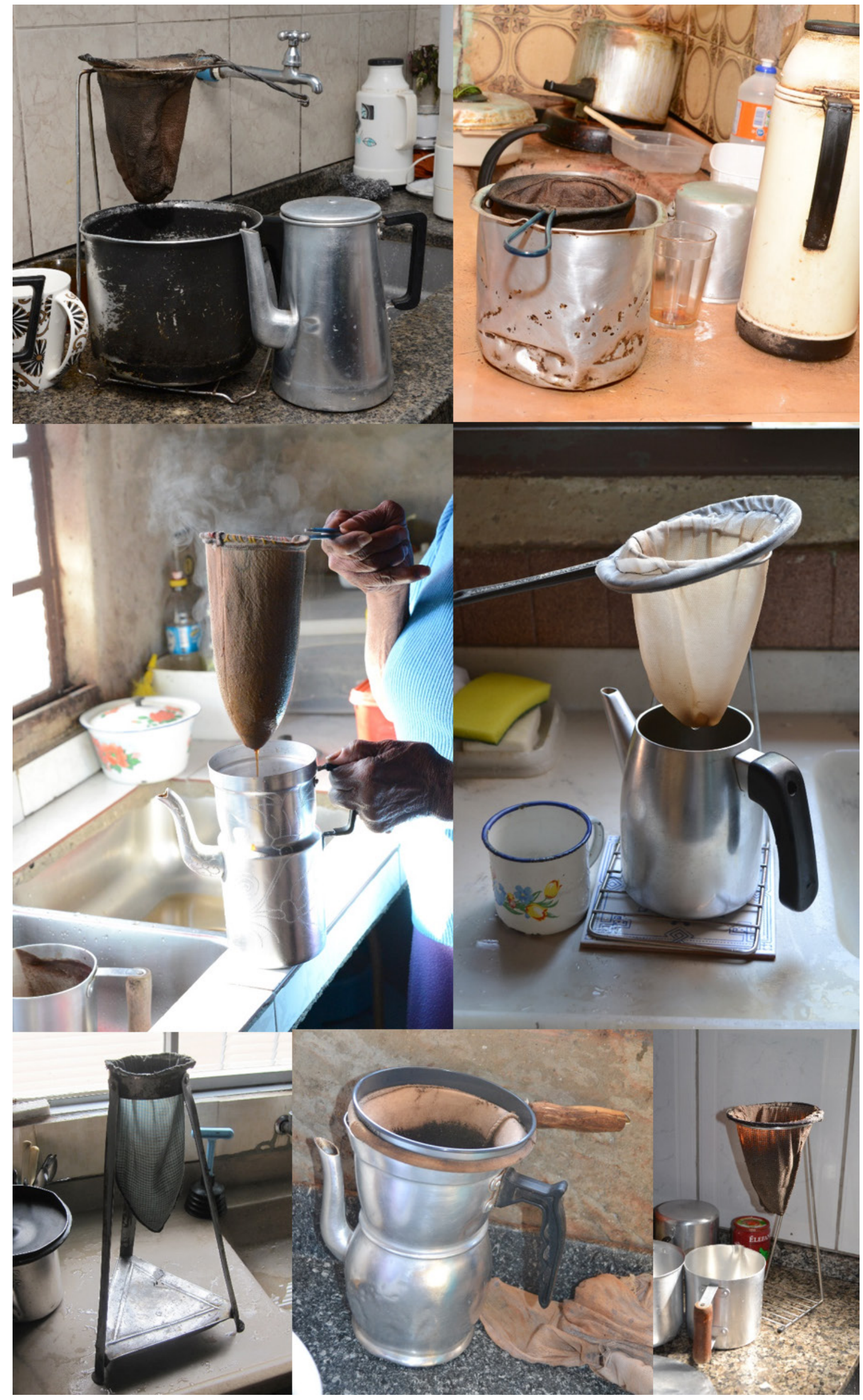




\section{Cobre-prateleira}

Este tipo de artefato foi agrupado e analisado por sua semelhança funcional e não formal. Trata-se de um recurso utilizado para cobrir prateleiras que abrigam toda espécie de objetos: panelas, enfeites, porcelanas, mantimentos ou imagens sacras. Normalmente, são feitos de tecido, com ou sem aplicação de bordados, mas também foram encontradas toalhas de plástico e de crochê.

Sua função não é fácil de compreender: de um lado, há relatos de que os paninhos servem para proteger as prateleiras de eventuais riscos feitos pelos objetos ali colocados. Por outro, há uma noção de que a prateleira não é higiênica e, portanto, a louça ali colocada precisa de alguma proteção. Neste caso, os paninhos são retirados de tempos em tempos para serem lavados. Ainda há casos nos quais estes objetos têm apenas a função de enfeitar a estante, ornamentando o espaço entre as prateleiras. Nestas ocasiões, os cobre-prateleiras formam uma espécie de babado ou moldura no vão inferior. 


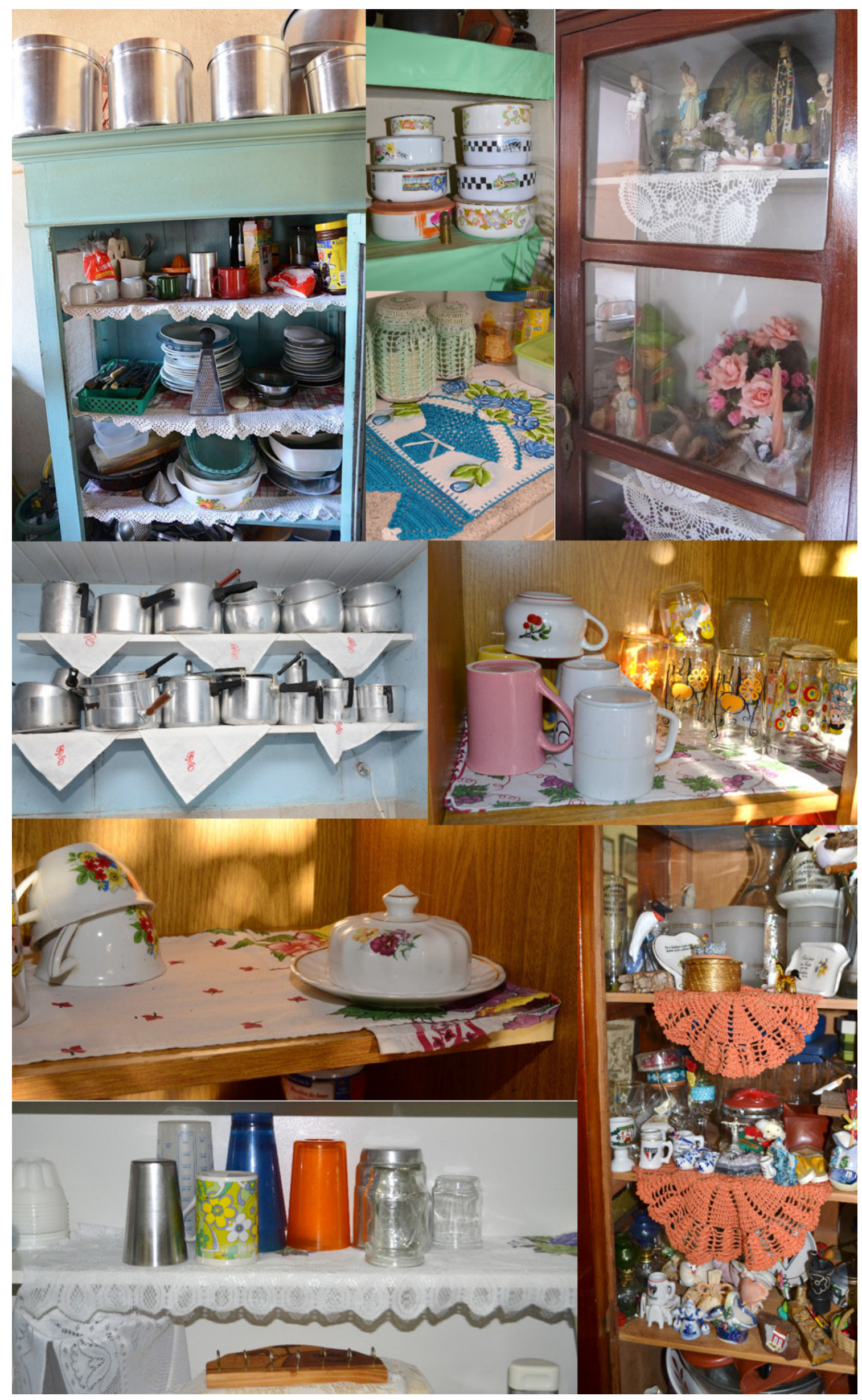




\section{Cobre-talha}

O cobre-talha é um artefato de proteção e enfeite. Uma vez que a talha, ou filtro de barro, encontra-se sempre na cozinha da casa, este objeto serve para protegê-la de eventual poeira. Por ser feito de tecido ou bordado em crochê, pode ser lavado, o que confere um ar de higiene ao filtro, muitas vezes já escurecido pelo tempo, uma vez que é feito de cerâmica natural. Mas o cobre-talha também atua como um elemento puramente estético, enfeitando a cozinha.

Alguns cobre-talhas encontrados seguem o formato e o tamanho da talha e foram feitos especialmente para esta função. Neste caso, podemos observar algumas peças feitas em crochê; em tecido de algodão com apliques bordados e barra em piquet (tipo de tecido); em tecido estampado, que combina com a toalha de mesa por terem a mesma estampa; e ainda uma versão feita pela moradora a partir da reutilização de uma cortina de renda sintética de cozinha. Há, por fim, outras ocorrências de pequenas toalhinhas sobre a talha, caso em que o artefato não segue a forma da talha, mas cumpre função semelhante de proteção e enfeite.

Nota-se, aqui, a ocorrência de peças produzidas pelas moradoras e outras compradas prontas. 


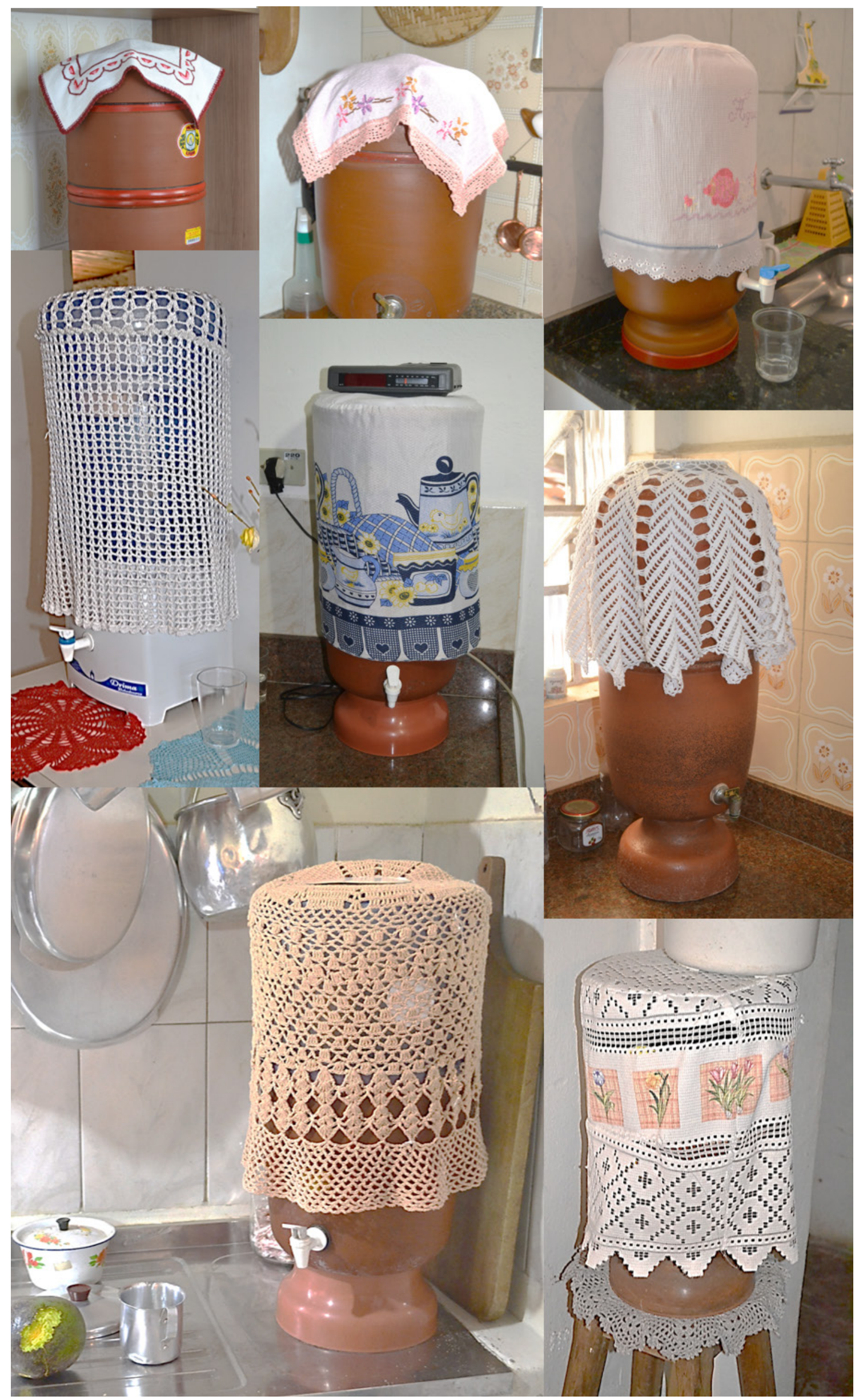




\section{Colcha e almofada de retalhos}

As colchas e almofadas de retalhos foram agrupadas num mesmo tópico, pois, apesar de serem artefatos com funções diferentes, têm o mesmo princípio formal e conceitual. Tratam-se de objetos produzidos pelas moradoras, a partir do aproveitamento de sobras de tecido (retalhos costurados) para a confecção de uma peça maior.

No caso das colchas, a função principal é proteger a roupa de cama da poeira, além de enfeitar o quarto. Já as almofadas têm um papel utilitário, embora também essencialmente estético.

Em duas almofadas, pode-se observar um controle na disposição dos retalhos com relação a cores e tipos de tecido. Nos demais casos observados, percebe-se que a noção do aproveitamento dos retalhos é maior do que o critério de escolha das cores e estampas, inclusive misturando tecidos com texturas e caimentos distintos, originando uma composição aparentemente aleatória. 


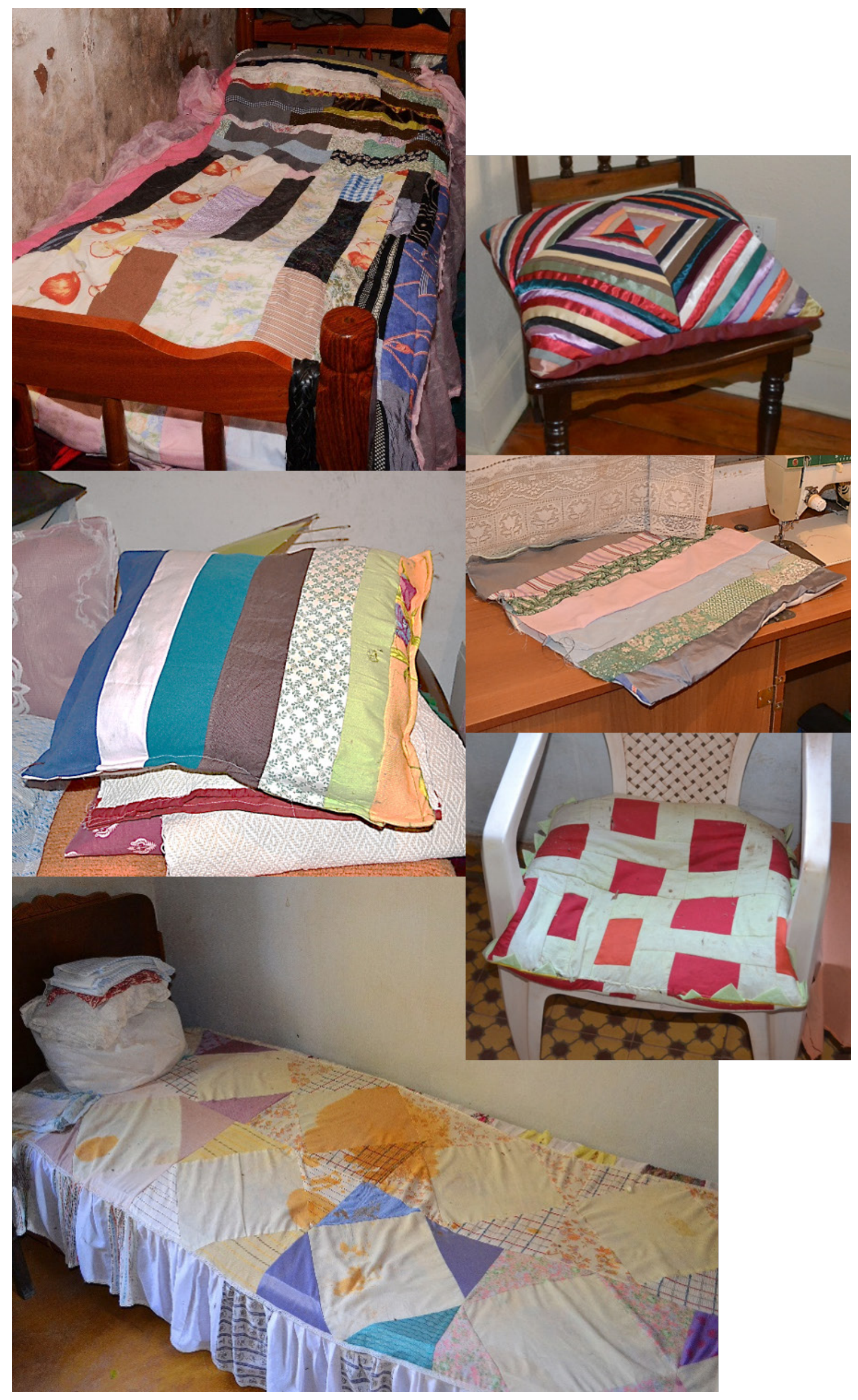




\section{Colcha de crochê}

As colchas de crochê foram encontradas, durante a pesquisa de campo, mais raramente do que pequenos objetos executados com a mesma técnica. Isto provavelmente se deve ao fato de que se levam meses para confeccionar uma colcha, enquanto pequenas toalhinhas são produzidas em dias.

Mesmo assim, pudemos observar dois tipos diversos: colchas monocromáticas e coloridas. As primeiras têm aspecto uniforme e são feitas com um só tipo de linha e cor, com pontos trabalhados ou repetidos. Pudemos notar orgulho em relação a estas peças por parte das moradoras que as produziram. Tais artefatos foram apresentados como uma conquista pessoal e com certa reverência de filhas e netas presentes na entrevista em relação ao feito. Isto se deve ao fato de sua produção ser trabalhosa e demorada e, sendo de uma só cor, não ser possível disfarçar qualquer irregularidade em sua confecção.

Por outro lado, temos a presença de colchas coloridíssimas, feitas a partir de quadrados independentes que são unidos ao final. Em um dos casos, há o relato de uma entrevistada sobre o processo de confecção: "eu fiz as partes coloridas e foi a minha mãe que uniu tudo". Outro detalhe interessante, nestes casos, diz respeito ao aproveitamento de restos de novelos usados em outros trabalhos, reforçando a ideia de evitar o desperdício, notada em outros casos relatados. 


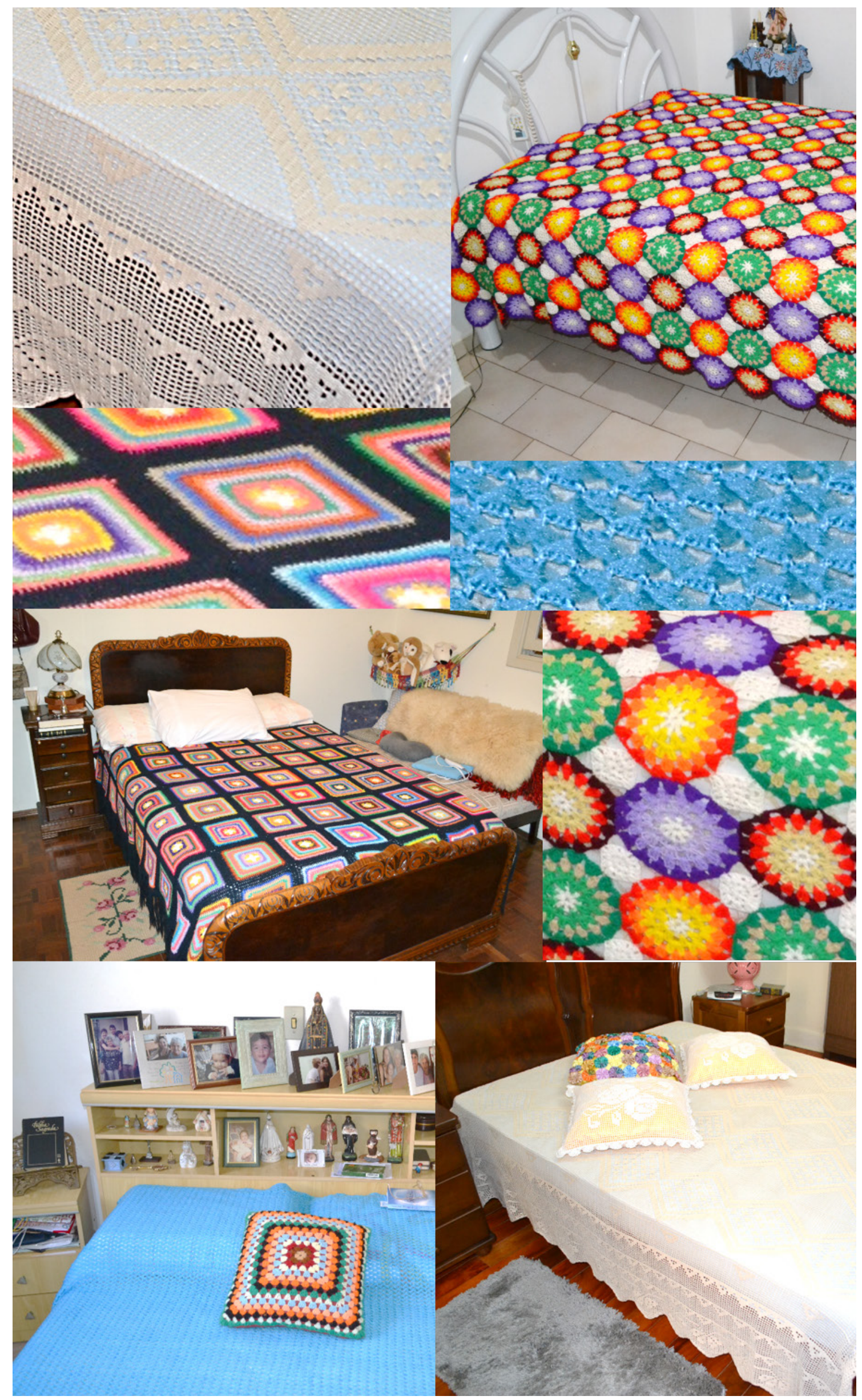




\section{Comigo-ninguém-pode}

A planta comigo-ninguém-pode apresenta certas particularidades que nos interessam: aparece geralmente em vasos (apenas em uma das ocorrências se viu plantada no jardim), na entrada da residência, e está associada à crença de que protege a casa e seus moradores contra o mau-olhado. Para que seu efeito se concretize, a planta (ou a muda) não pode ser comprada, mas recebida de presente. Em todos os casos, a muda da planta foi dada ao entrevistado por algum conhecido com a boa intenção da proteção.

Não se sabe qual é a origem desta crença, mas podemos ligá-la ao fato de que a Dieffenbachia seguine possui uma alta concentração de uma substância química extremamente tóxica, chamada oxalato de cálcio, capaz de matar uma pessoa por envenenamento se ingerida ${ }^{3}$.

As amostras encontradas variam quanto ao formato de folhas e à coloração, mas todas pertencem à espécie conhecida como comigo-ninguém-pode. 


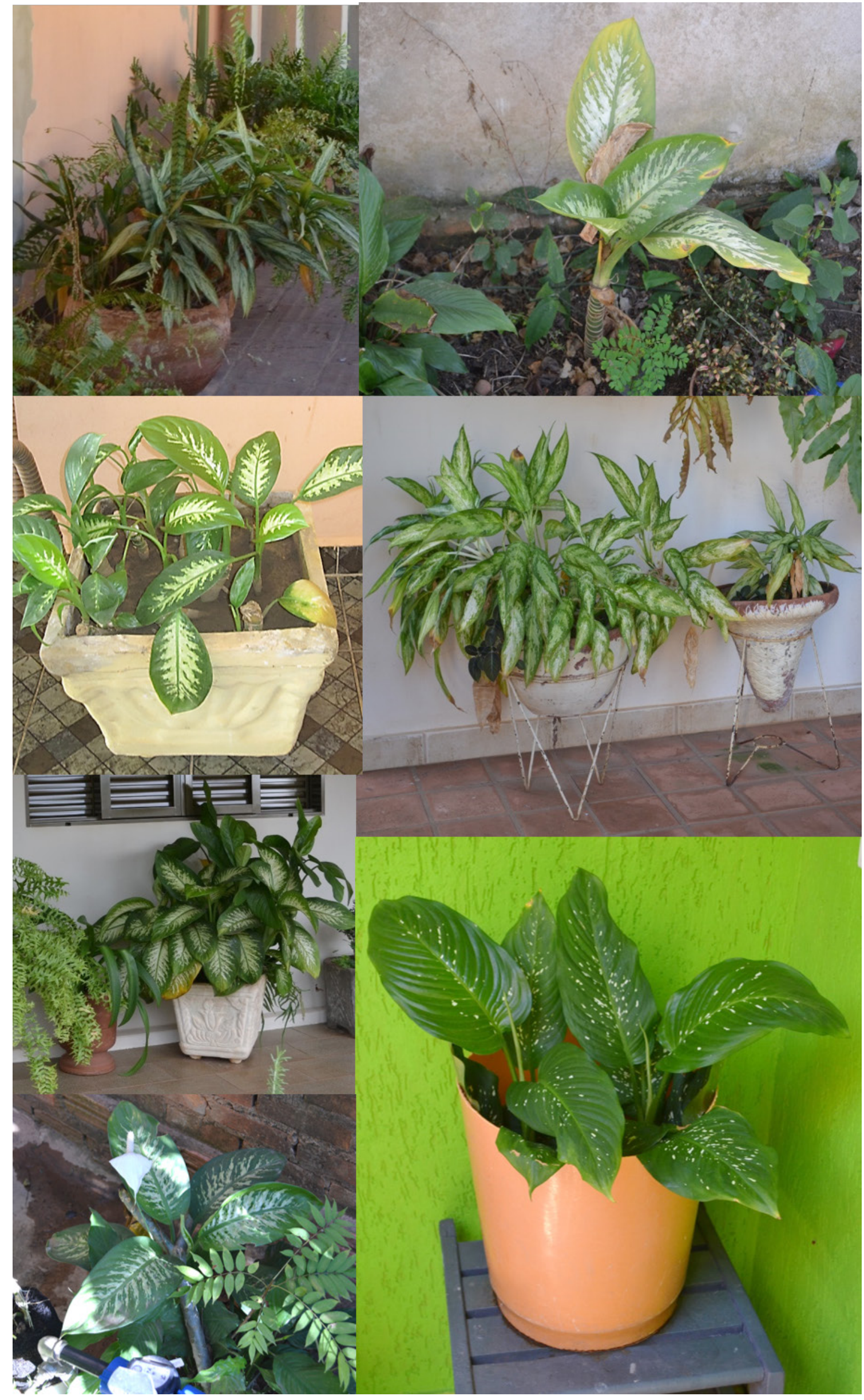




\section{Copo "bico de jaca"}

O copo "bico de jaca" tem este nome por causa da textura externa de seu vidro, que lembra a casca de uma jaca, com pequenos elementos piramidais. Na versão transparente ou âmbar, estes copos estão associados à noção de status.

Vale relatar que, em todas as residências visitadas, ofereceram-nos água e café e, na maioria das vezes, o copo utilizado para a água era desse tipo.

Mais de uma vez, ouvimos o relato sobre o jogo de copos ter sido dado como presente de casamento, "pois naquela época era chic".

Em uma das residências, sobrou um único copo do jogo de meia dúzia ganho como prêmio na barraca da argola da quermesse de uns anos antes. 


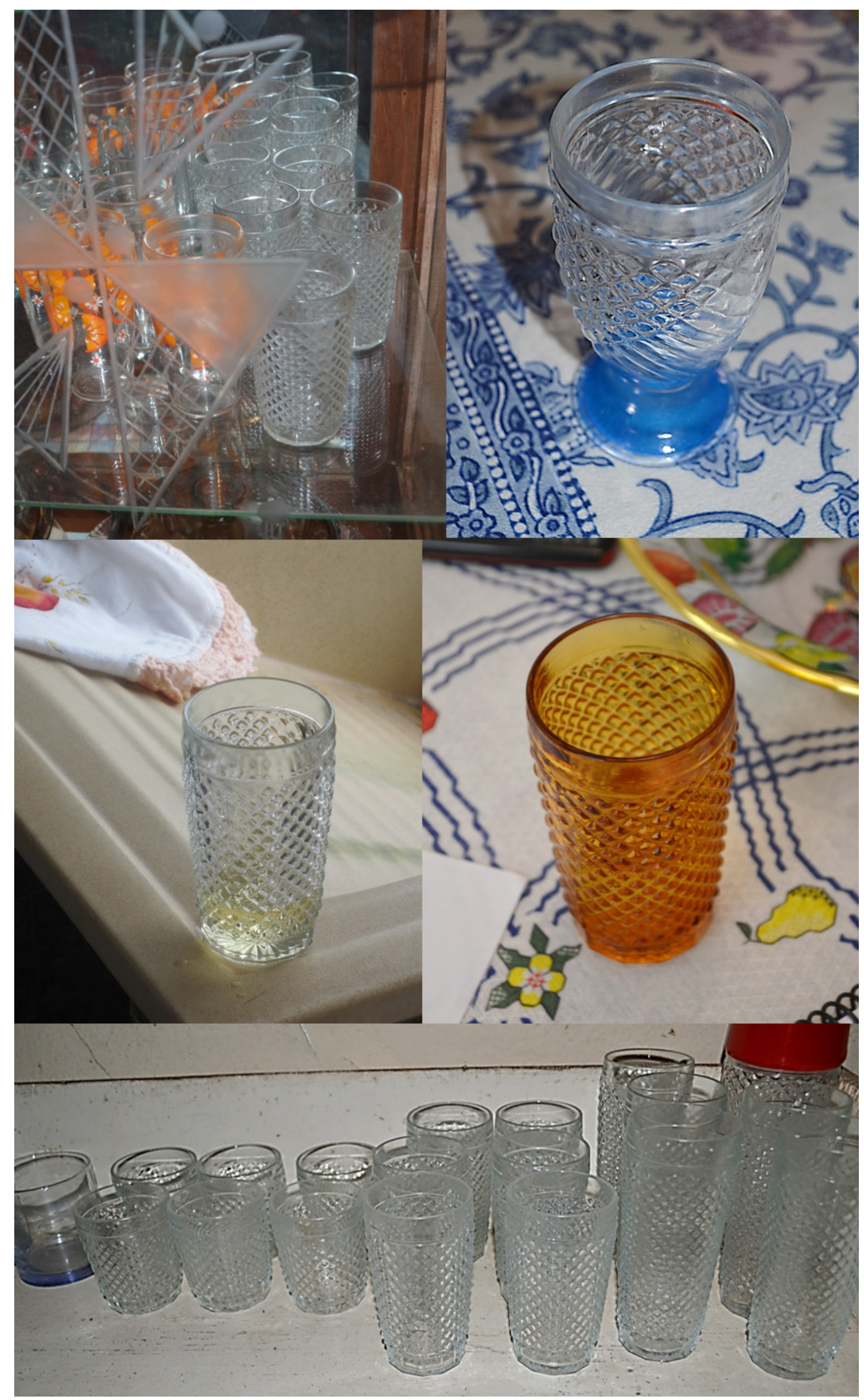




\section{Copo para café}

O uso de copo de vidro tipo "americano" para tomar café parece ser bem comum dentre a população visitada. Perguntados pelo motivo que os levava a utilizá-lo, ao invés da xícara, os moradores variaram suas respostas entre dois fatores. O primeiro, é de ordem reflexiva e tem relação com o hábito, podendo ser resumido pela expressão "é costume". O outro, é pragmático ou comportamental (NORMAN, 2008) e tem ligação com a ergonomia do copo que, mais alto do que o necessário, evita que se queime a mão ao segurá-lo. 


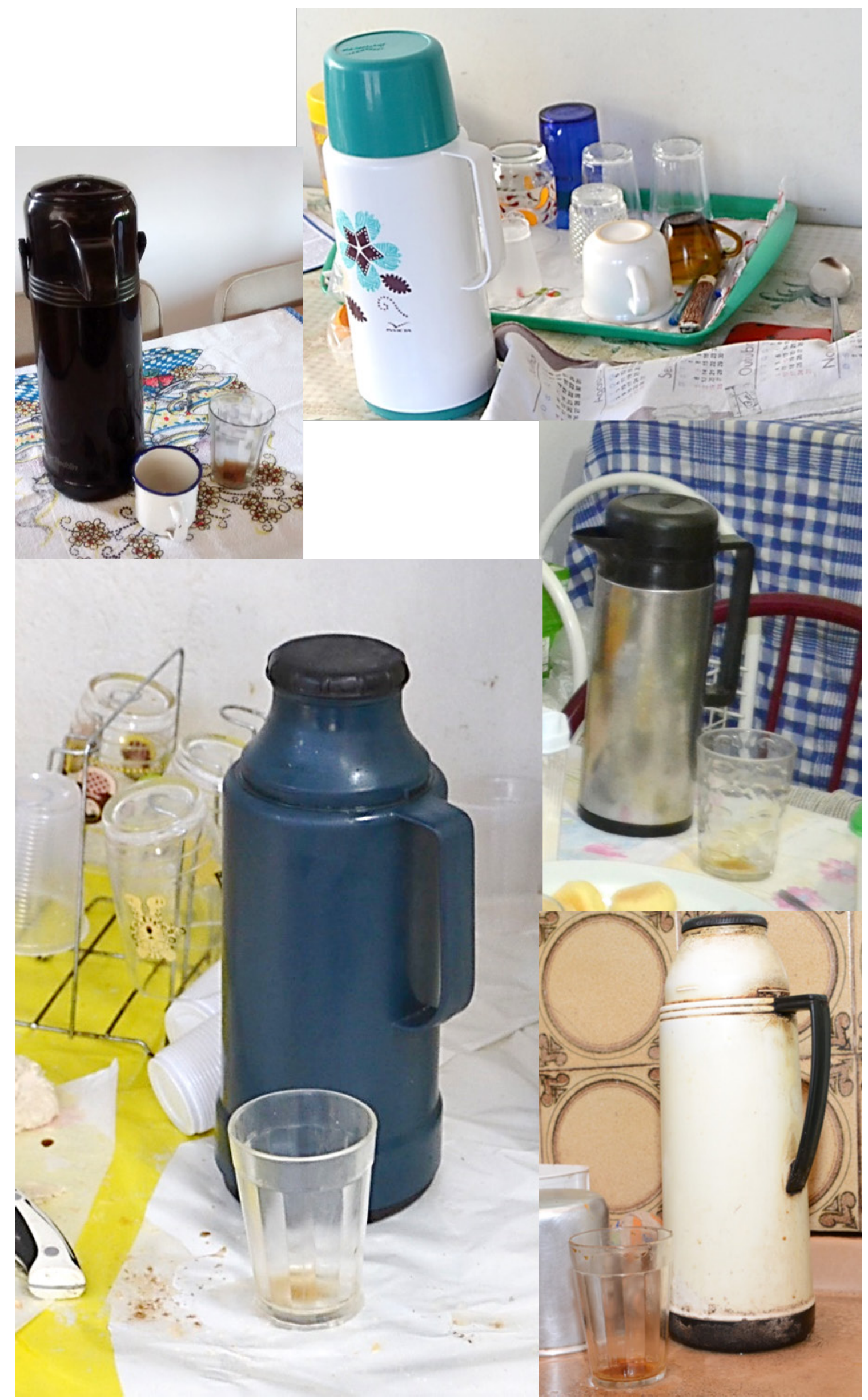




\section{Cortina de renda}

As cortinas de renda estão presentes em salas e quartos. São tradicionalmente de renda branca (algumas já amareladas pelo tempo), franzidas, colocadas em trilhos escondidos por bandôs ou pelas pregas-macho. Muitas apresentam babados em seus arremates.

Pudemos encontrar diferentes versões: as mais tradicionais, somente com pregas, sem sobreposição; outras com xales e panôs embabadados ou arremate de cetim; e também as mais atuais, de renda sintética, muito utilizadas em vitrôs de cozinhas, conhecidas como "cortinas holandesas" em lojas especializadas. 


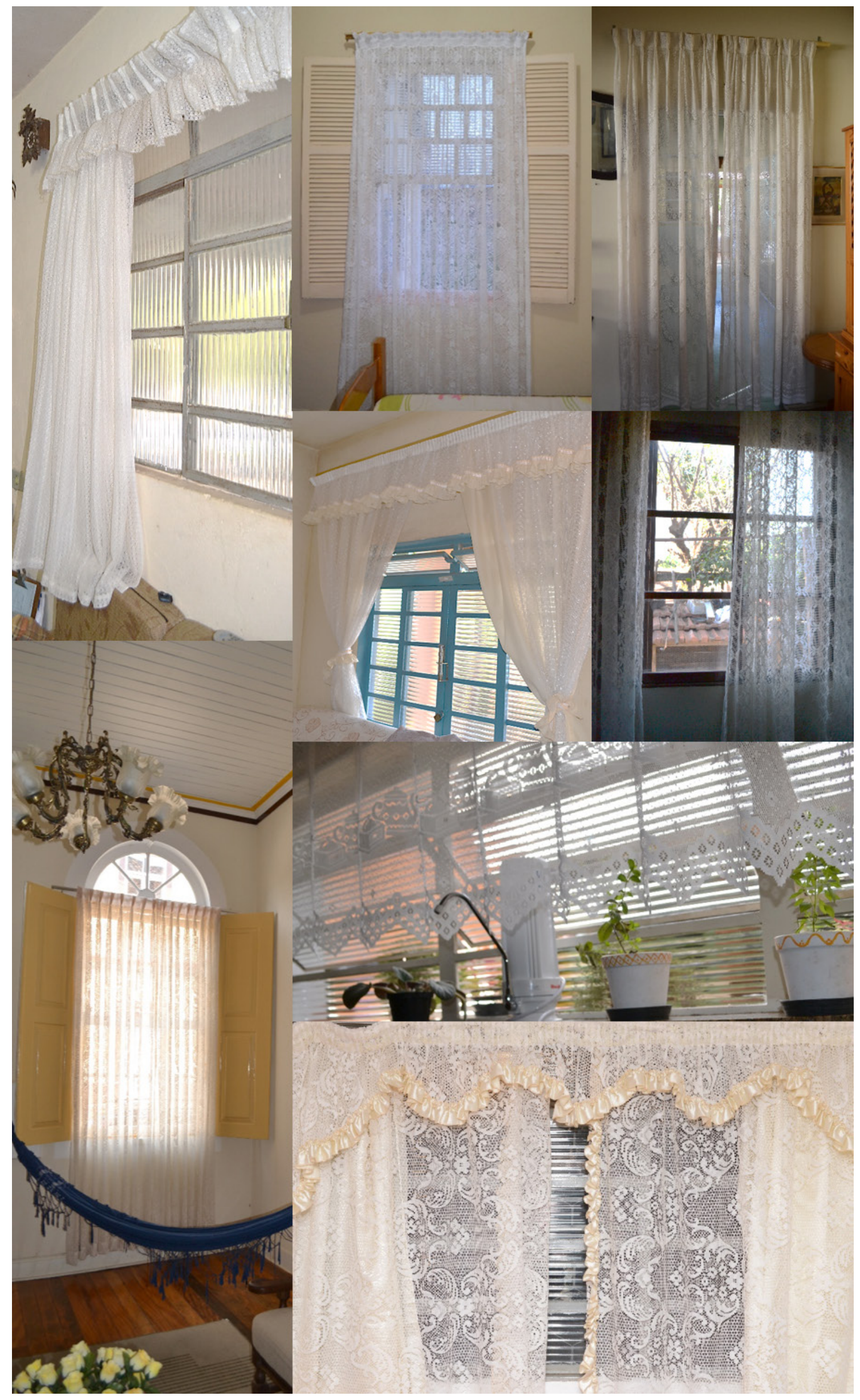




\section{Crucifixo}

Os crucifixos estão presentes tanto sobre móveis da sala ou do quarto, em forma de pedestal, quanto pendurados nas paredes, de preferência sobre o batente da porta, em sinal de proteção.

Foram encontradas diferentes versões, que vão dos mais simples e rústicos, de madeira, sem a imagem de Cristo, até os mais trabalhados, que misturam materiais como madeira para o fundo e metal fundido (bronze) para a figura de Cristo e demais apliques de enfeite.

Em duas residências visitadas próximas à Páscoa, pudemos encontrar folhas secas de palmeira colocadas junto ao crucifixo, trazidas da missa de celebração do Domingo de Ramos, como reza a tradição cristã. 


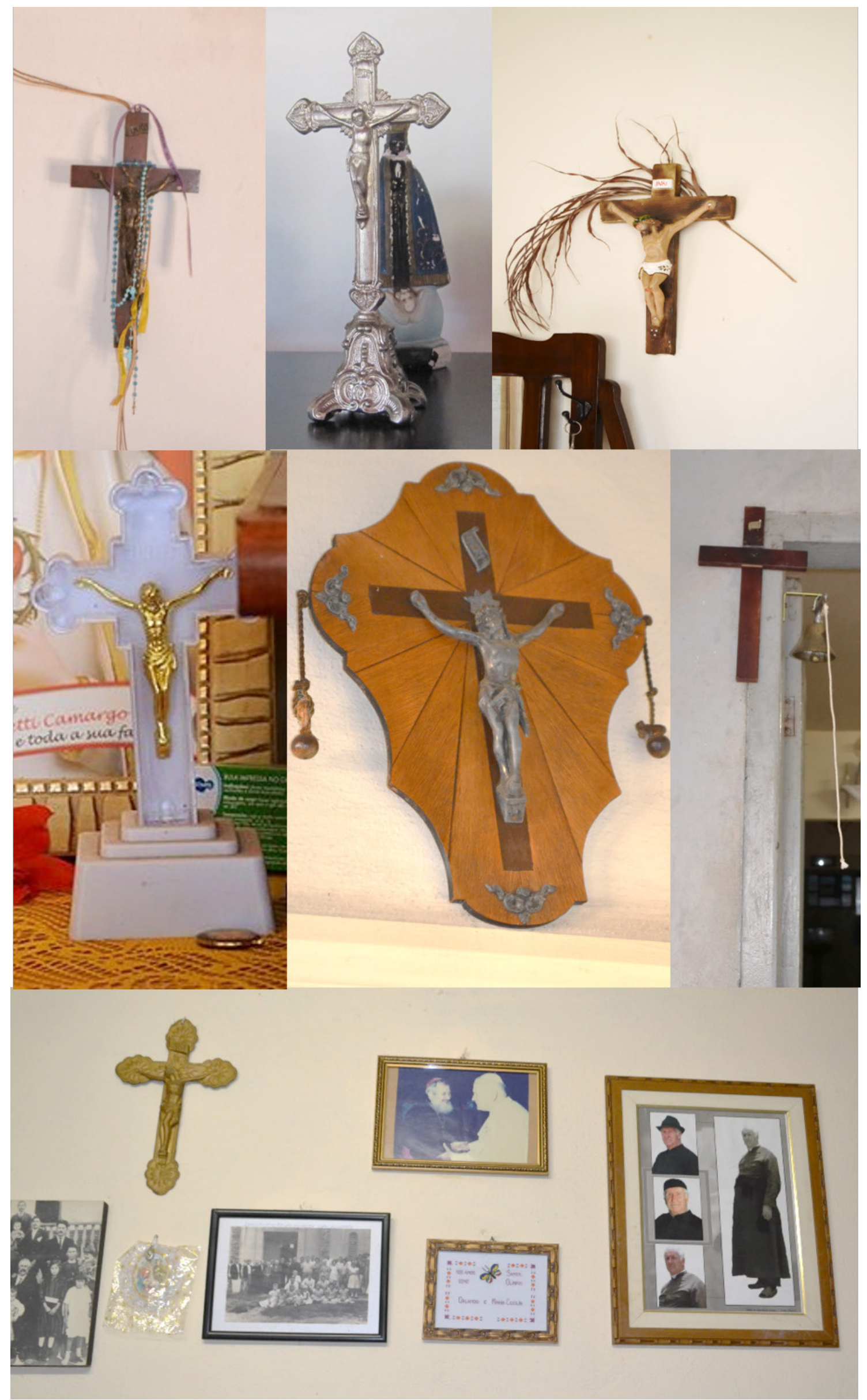




\section{Espelho de banheiro com moldura de plástico}

O espelhinho de banheiro com moldura de plástico, que varia de tons de laranja a abóbora, é um objeto que, apesar de sabermos existir em várias residências visitadas, não estava exposto. Apenas em algumas das casas pudemos localizá-lo sobre um móvel de quarto ou pendurado em algum prego na parede. Quando indagados sobre o artefato, contudo, os entrevistados sempre afirmavam possuí-lo.

Considerado prático e barato (seu preço equivale ao de uma passagem de ônibus) e facilmente encontrado em mercados, feiras e pequenos comércios locais, em algumas visitas, era o único espelho da casa.

Embora existam vários tamanhos disponíveis, por algum motivo que desconhecemos, os fabricantes só os produzem com a parte plástica em tons que vão do alaranjado ao abóbora. 


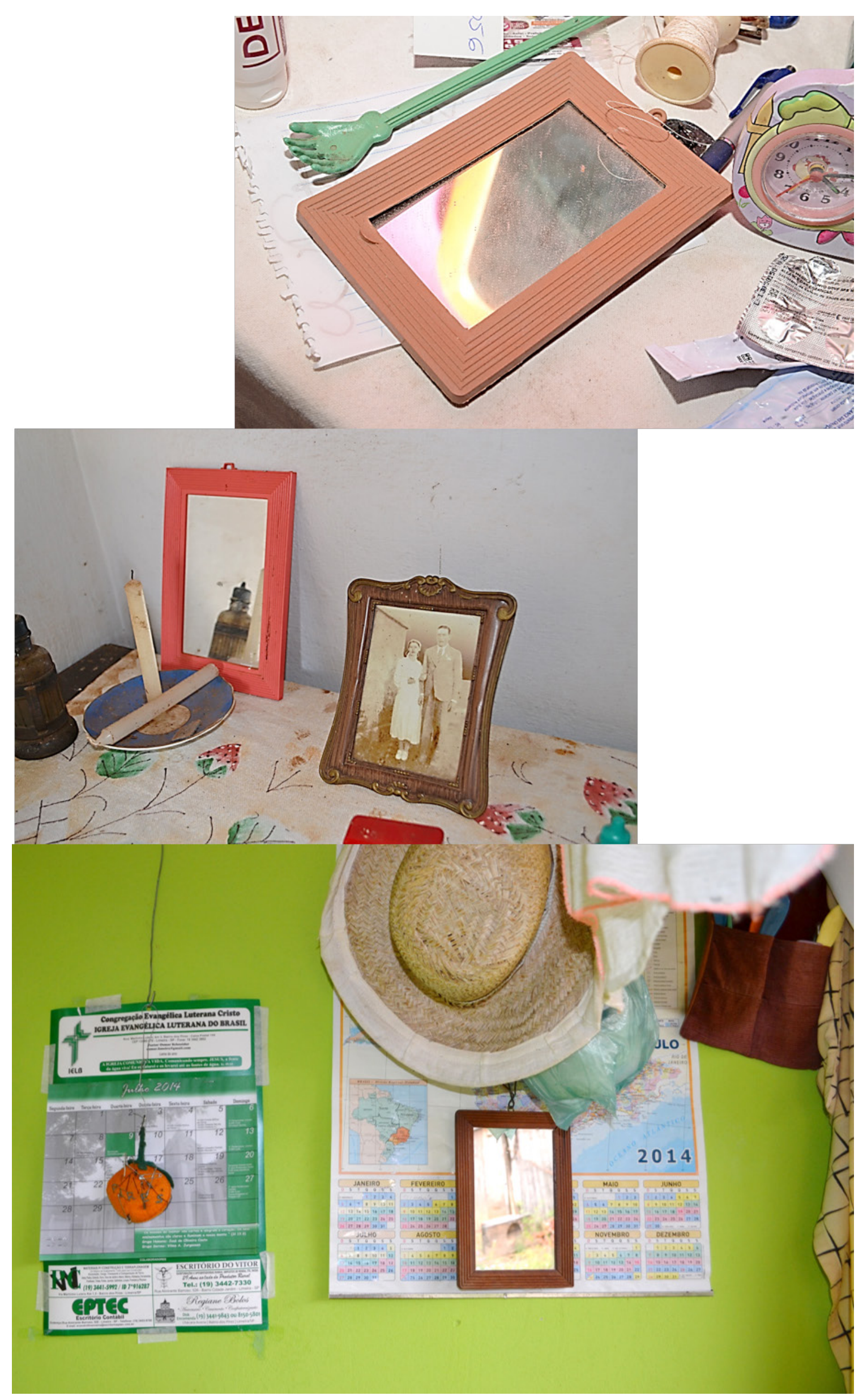




\section{Ferro a carvão}

O ferro a carvão foi encontrado em algumas residências, embora já não fosse utilizado para sua função original. Relacionado com o passado familiar dos entrevistados, relatos sobre a proveniência dos ferros dão conta de que alguns foram herdados e outros encontrados no lixo e recuperados.

Em dois casos, pudemos notar a relação destes objetos com a infância das moradoras, suas memórias dos tempos de criança na roça com suas mães. Em outra ocorrência, a moradora é colecionadora de ferros a carvão e seus vários modelos, de diferentes fabricantes, ficam expostos sobre uma prateleira de alvenaria na sala.

Feitos de ferro fundido com um compartimento para ser abastecido de carvão em brasa, estes artefatos foram muito utilizados até a chegada da eletricidade e posteriormente do ferro elétrico nas primeiras décadas do século XX.

Também conhecido como ferro a brasa. 


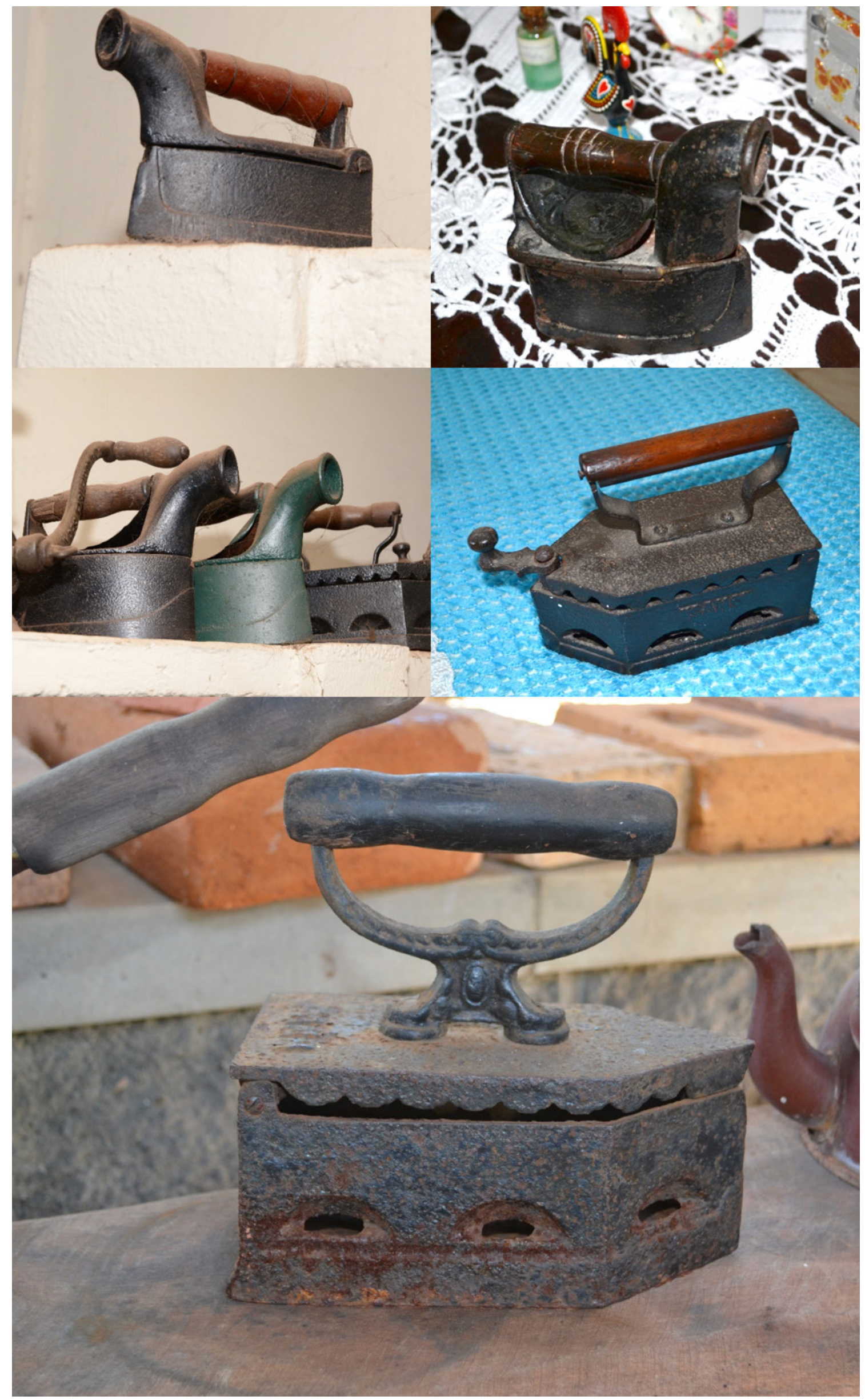




\section{Filtro de água de barro (talha)}

A talha é a alternativa mais comum encontrada para a solução do problema da água potável nas residências visitadas.

Algumas características relevantes em relação ela: mantém a água em uma temperatura agradável (fresca), devido ao isolamento natural da parede cerâmica; deixa a água com um gosto de barro (relatado por alguns entrevistados como um sabor agradável); é extremamente durável, ainda que, de tempos em tempos, seja necessário trocar sua "vela" (o filtro de carvão interno). Para a higienização de sua parte interna, que tende a criar limbo com o tempo, usa-se açúcar.

A talha fica geralmente sobre a pia da cozinha pela facilidade em abastecê-la com a água da torneira.

Em uma das residências, pudemos observar um galão de plástico com água mineral entornado sobre a talha. Indagado o motivo, a moradora esclareceu que a adaptação foi realizada por preferir a água mineral à água encanada da cidade, mas que não abre mão do frescor que o filtro de barro confere à água. 


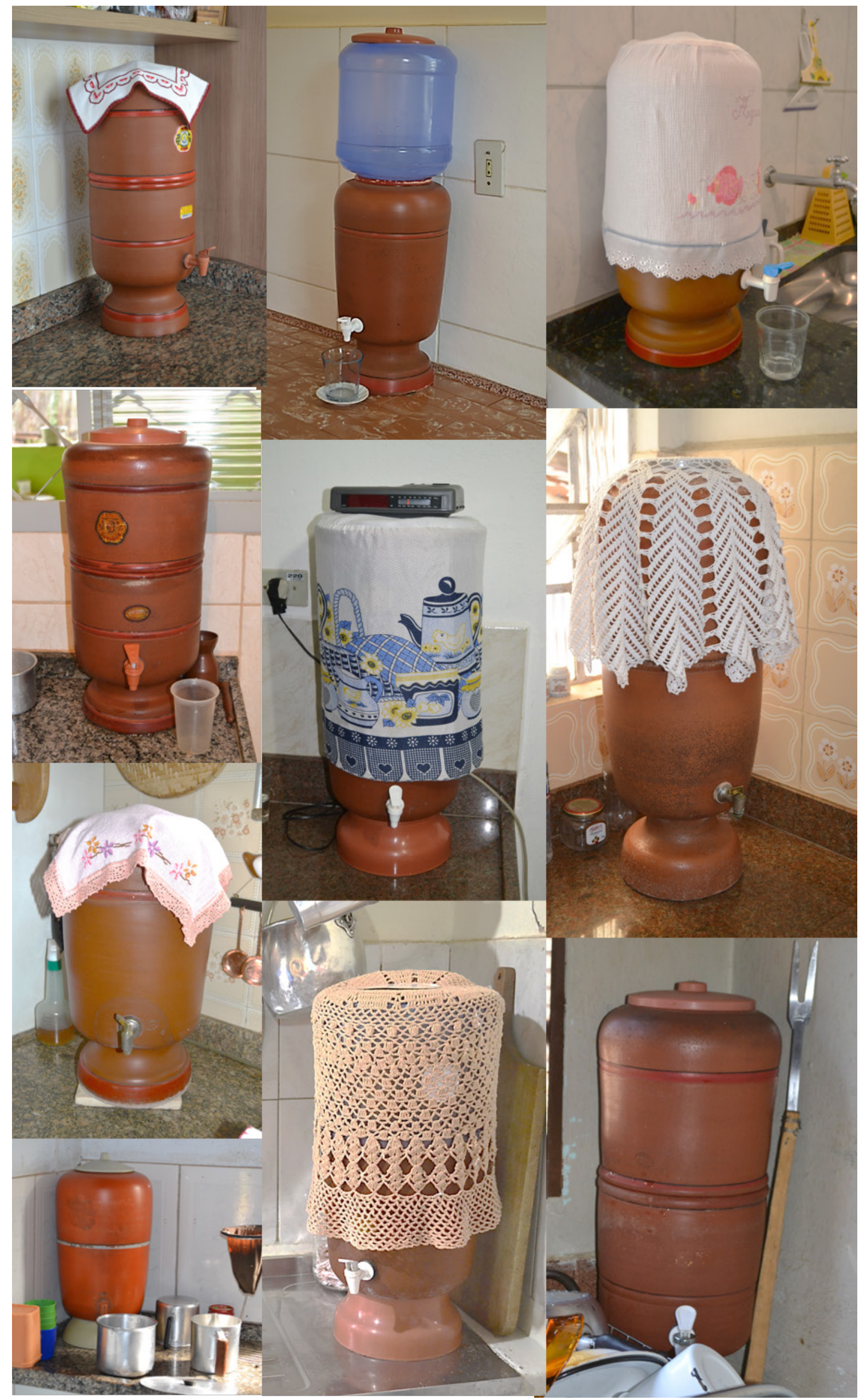




\section{Fogão a lenha}

O fogão a lenha foi encontrado em várias residências visitadas, tanto nas cozinhas internas quanto em espaços cobertos exteriores à casa, conectados à cozinha. Apesar de hoje ser possível comprá-lo pré-fabricado em cimento armado, em todas as ocorrências observadas, os fogões foram construídos em alvenaria no próprio local. Algumas versões apresentam forno embutido também.

O modo de se cozinhar no fogão a lenha é distinto do fogão a gás. Mais trabalhoso para se acender, é mantido aceso com pouca lenha e fogo bem baixo por todo o dia, só atiçado durante o preparo das refeições. Por este motivo, é ideal para o preparo de doces de frutas, geleias ou doce de leite, que necessitam de horas de fogo bem baixo para "pegar o ponto certo", e também para manter a comida aquecida para aqueles que se atrasam na hora do almoço. A panela ideal para o fogo a lenha é a de ferro, por ter uma parede mais espessa e por ser naturalmente preta - já que esse tipo de fogão escurece a panela.

Outro hábito interessante associado ao fogão a lenha é o da defumação: em uma residência visitada na área rural, pôde-se observar a banha do porco pendurada em uma espécie de varal sobre o fogão para ser defumada pela fumaça e pelo calor.

Há uma crença de que o café feito no fogão a lenha é mais gostoso em função da temperatura correta da água, mantida aquecida no bule em fogo brando.

Uma entrevistada que mora na mesma casa que foi de seus pais, onde nasceu e cresceu, nos relatou que seu pai usava uma espiriteira a querosene durante a noite para aquecer o leite de sua mamadeira, uma vez que o fogão a lenha estava apagado e era muito trabalhoso acendê-lo para uma necessidade pontual como esta.

Em todas as residências em que foi encontrado o fogão a lenha, também havia fogão a gás.

Em alguns casos, onde não há coleta de lixo regular na zona rural, o fogão é usado também como incinerador de lixo. 


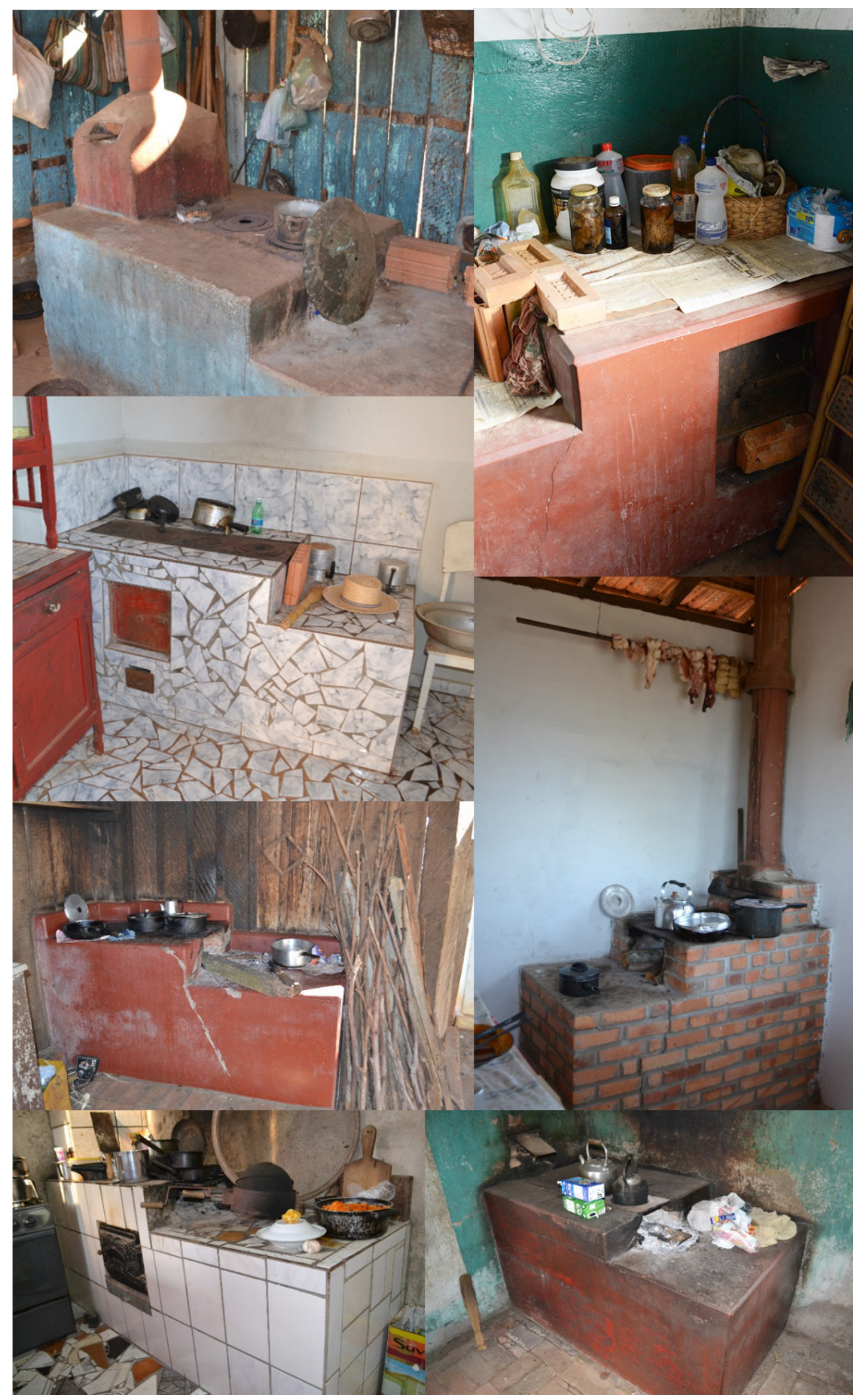




\section{Gaiola com pássaros}

Gaiola para pássaros é um objeto presente no universo pesquisado. Pelo que pudemos observar, a criação de pássaros presos na gaiola é um hábito essencialmente masculino entre os entrevistados.

Os tipos mais comumente encontrados são o canário, devido ao seu canto, e o papagaio, graças a sua habilidade em mimetizar a fala humana, o que o torna inteligente e divertido aos olhos do dono.

Os depoentes relatam que ganharam os pássaros, à exceção de um entrevistado que nos conta que o seu desejo é criar canário solto e, para isso, ele tem uma técnica que usa a gaiola:

Primeiro eu peguei no mato o canarinho macho que tá preso na gaiola. Depois eu vou colocar junto uma fêmea que eu vou ganhar de um colega. Aí ,deixa o casal junto por um tempo na gaiola até que eles se acostumem. Solta então o macho que ele vive solto em volta da fêmea. Depois de um tempo pode até soltar a fêmea que eles não vão mais embora.

As gaiolas ficam geralmente penduradas no madeiramento do beiral do telhado das casas ou de alguma varanda. No caso dos periquitos, a gaiola é retirada à noite e o animal dorme na cozinha 


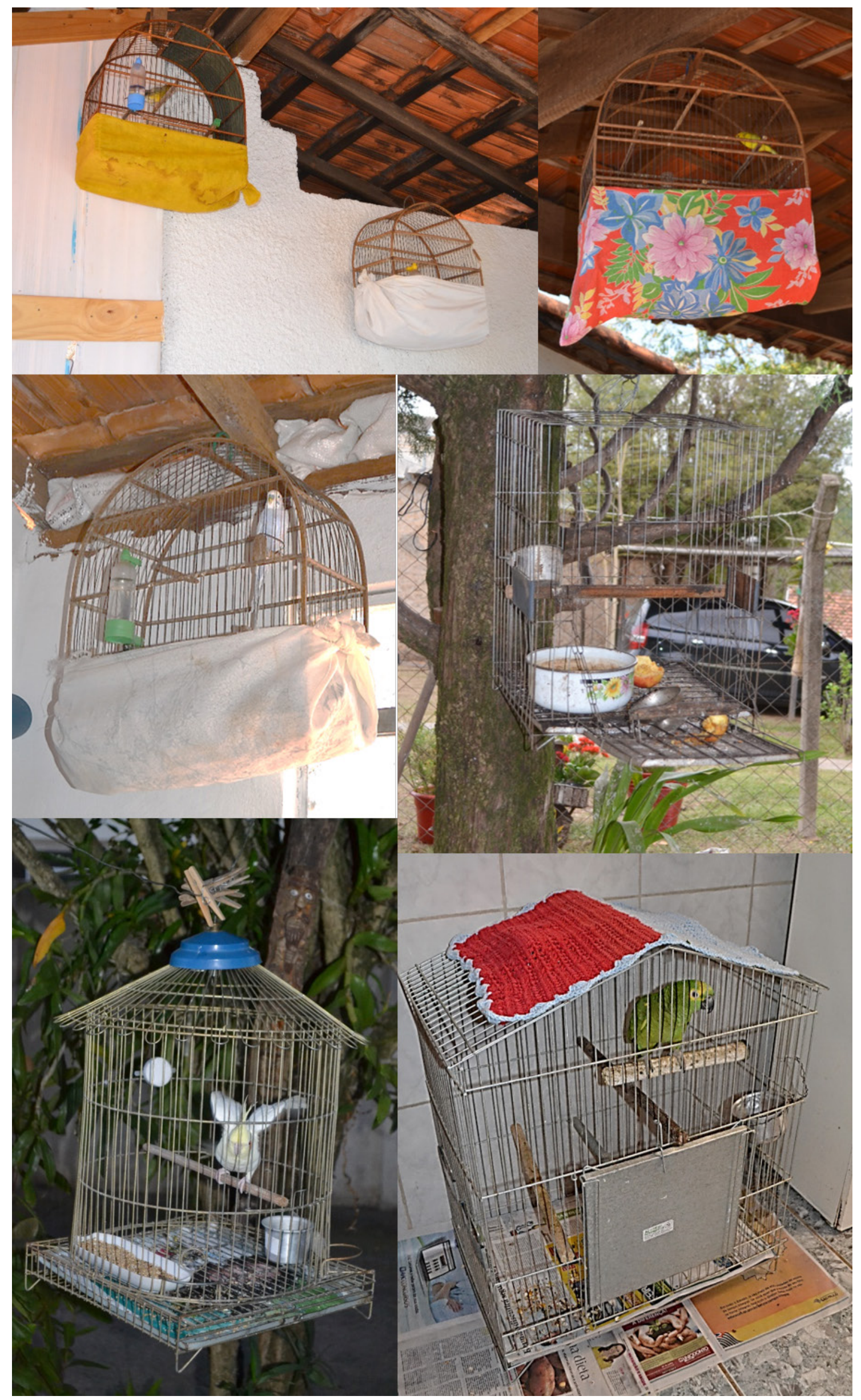




\section{Galinho português de previsão do tempo}

O galinho que prevê o tempo é um pequeno objeto feito de plástico, na forma de um galo, revestido com um material à base de cobalto que muda de cor conforme a umidade do ar, indo do rosa ao azul, indicando assim se vai chover ou não, de acordo com uma pequena legenda localizada em sua base.

A preocupação com o clima também pode estar associada à herança de uma vida no sítio, na qual a atividade de colheita e plantio é severamente afetada pelas chuvas.

Costuma encantar as crianças. 

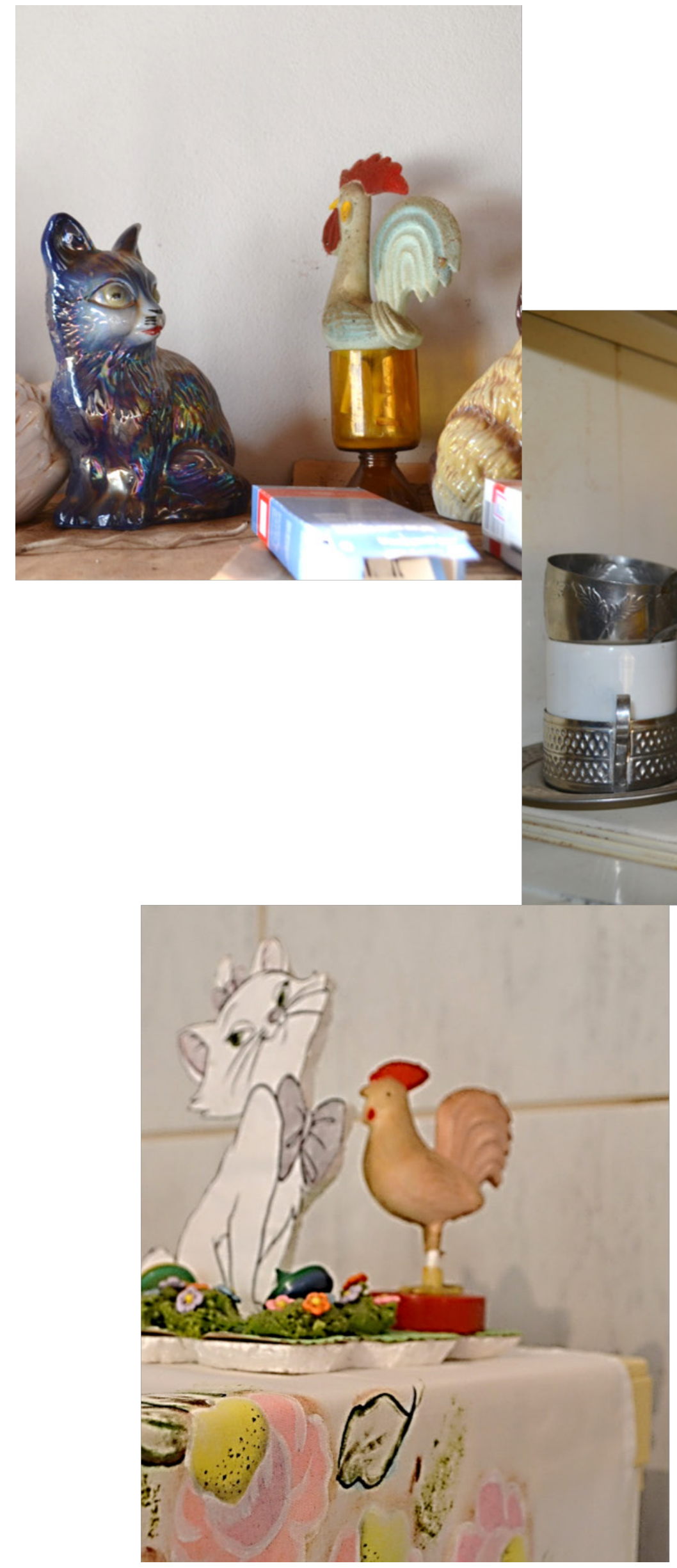


\section{Garrafa térmica com café}

A garrafa térmica com café fica normalmente sobre a mesa da cozinha junto a algumas xícaras e copos.

Símbolo de hospitalidade e hábito entre os brasileiros, oferecer um café é praticamente obrigatório nas residências dos paulistas visitados: se o café não estava já pronto dentro da garrafa, foi passado na hora (o que simboliza um cuidado ainda maior com a visita) em todas as ocorrências durante a pesquisa de campo.

As garrafas são de plástico, tradicionais, compradas em mercados e lojas, sem distinção de marca. As cores e estampas não são relevantes na escolha e sim seu sistema de fechamento: dentre os entrevistados, o de rosca é o preferido por ser considerado mais eficiente na manutenção da temperatura adequada do café por mais tempo, mas "faz sujeira pra servir... toda vez pinga na toalha." 


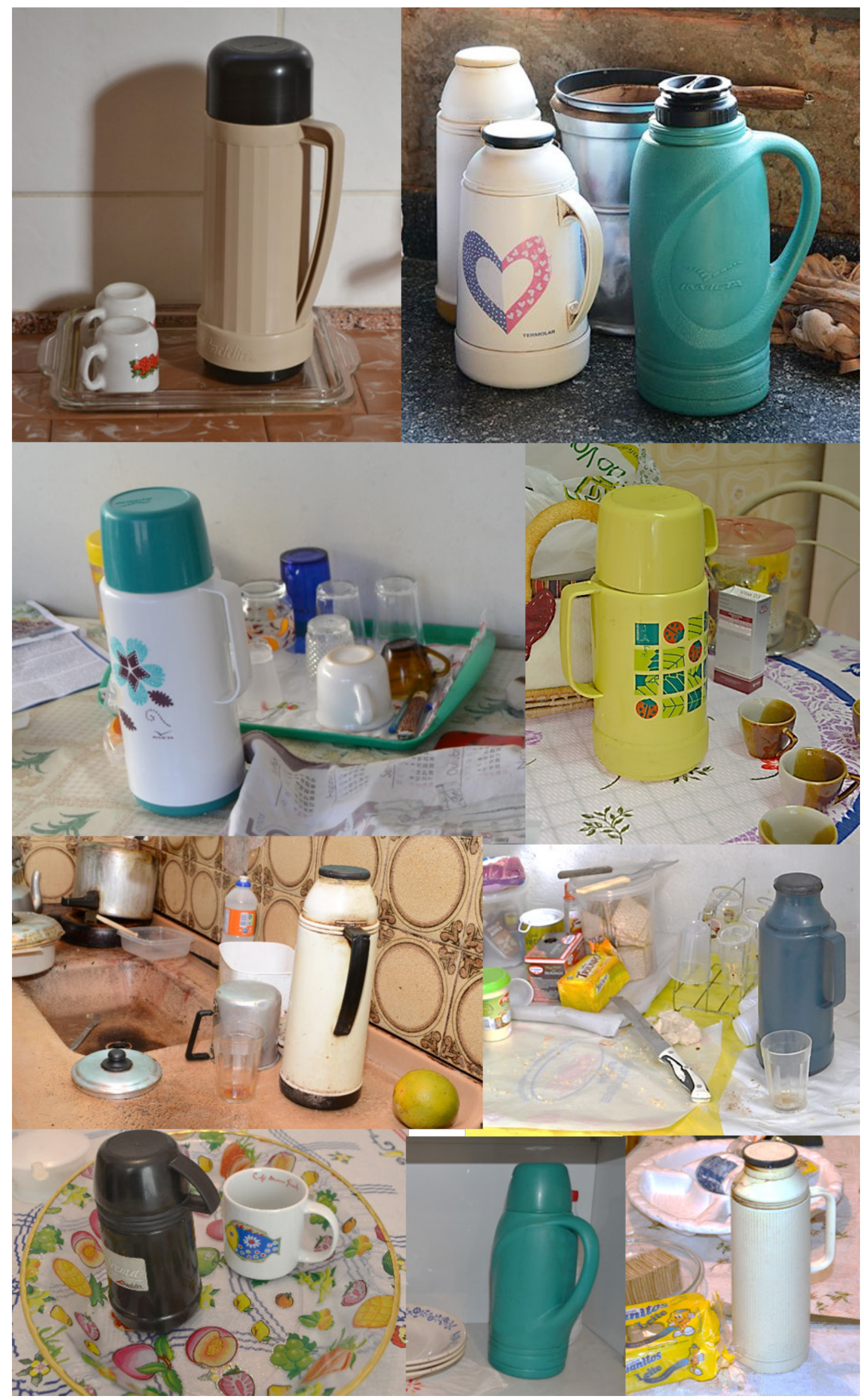




\section{Imagens de santos}

As imagens sacras estão presentes nas casas de todas as famílias de religião católica visitadas, só não aparecendo nas evangélicas.

Em sua maioria, são dispostas no ambiente formando pequenos altares. Costumam aparecer em companhia de outras imagens; vasos de flores e velas, em sinal de devoção e oferenda; porta-retratos de parentes já falecidos; terços e bíblias; sobre toalhinhas de crochê, em um móvel específico de qualquer cômodo da casa.

Em alguns casos, a imagem está provisoriamente de passagem em rituais da comunidade, como no caso do Divino Espírito Santo de uma residência em São Luís do Paraitinga, que recebe a imagem em rodízio numa espécie de novena.

A imagem mais presente é a de Nossa Senhora Aparecida, padroeira do Brasil.

A presença das imagens nos lares dos católicos visitados deve-se à manutenção do ritual religioso doméstico, reflexo da herança da casa caipira dos bairros distantes da vila e da paróquia mais próxima. 


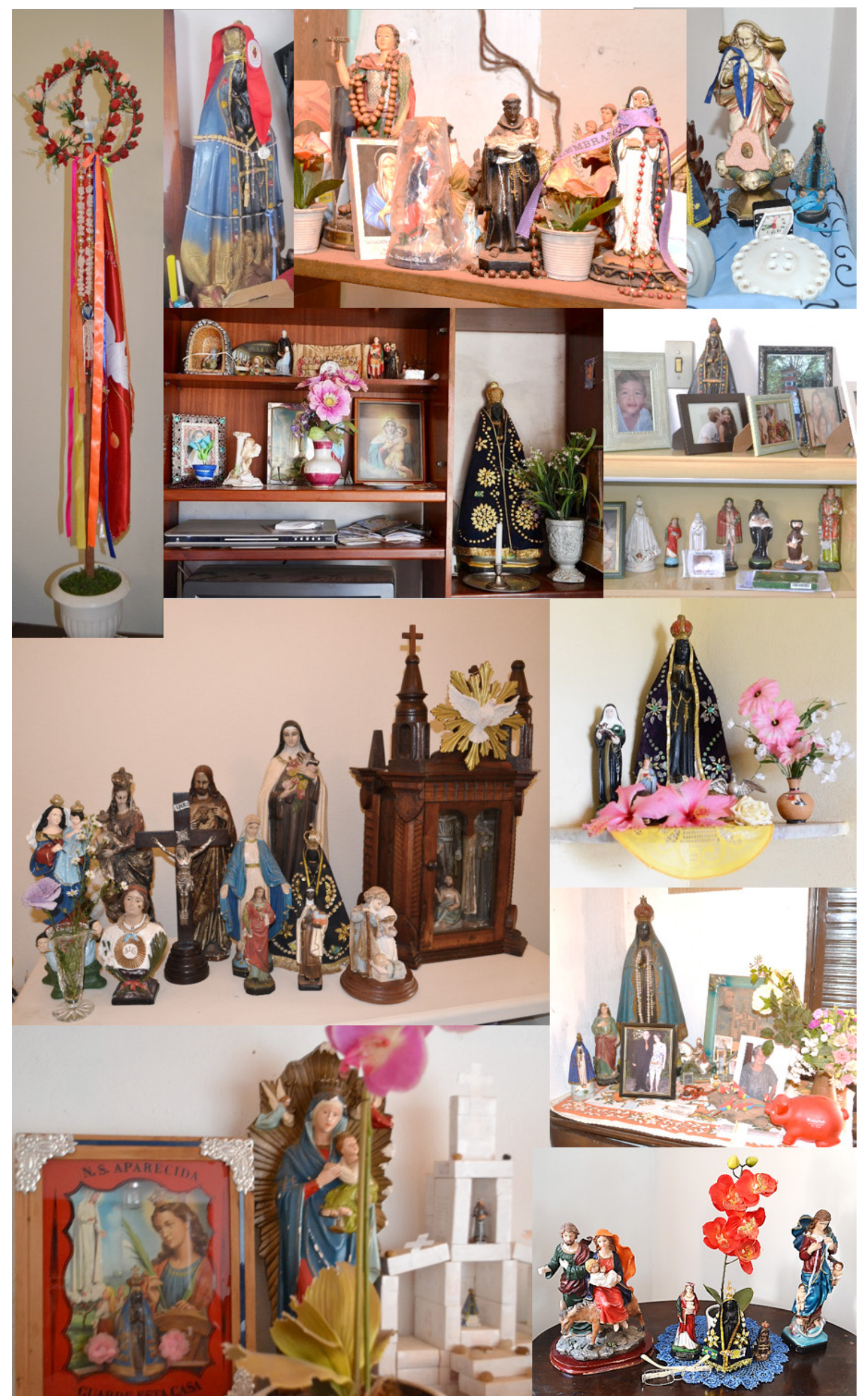




\section{Jarra de leite}

As jarras de leite de porcelana foram encontradas em algumas residências, apesar de não serem mais utilizadas em sua função original.

Tendo feito parte de um jogo de porcelanas no passado, assim como o bule já "desparceiradas", são mantidas como relíquia por algumas moradoras que as utilizam principalmente para suco.

Chama a atenção sua decoração em motivos florais. 


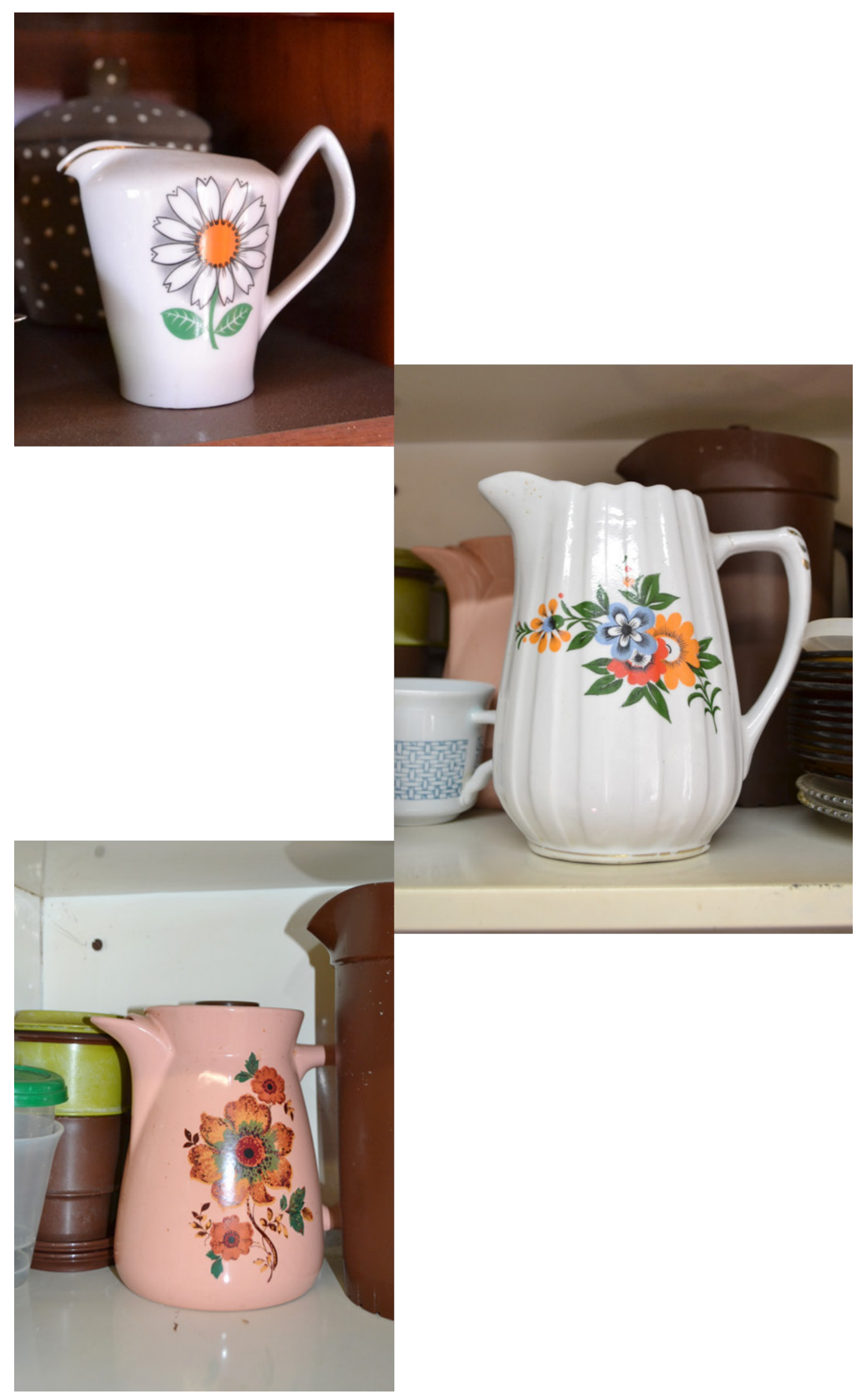




\section{Máquina de costura}

As máquinas de costura aparecem em vários relatos associados a diferentes valores: como a habilidade manual esperada de uma boa dona de casa; como um modo de ganhar dinheiro sem trabalhar fora; como vínculo familiar quando se trata de uma herança; e como um símbolo da autonomia da unidade familiar, novamente uma tradição caipira dos bairros rurais.

As marcas mais comuns são Singer, Elgin e Vigorelli, e os modelos são os a pedal.

Há relatos de senhoras que herdaram a máquina de algum parente que já não costura mais, da mãe já falecida ou ainda ganharam como presente de casamento do pai. Em apenas um caso, a máquina foi comprada pela própria depoente.

Nos relatos de memória da infância, a máquina de costura da avó foi muito citada como um objeto típico daquele ambiente "com suas gavetinhas misteriosas."

Em todos os casos, aprender a costurar com a máquina foi um conhecimento transmitido de modo oral por alguma senhora mais velha, da família ou próxima. 


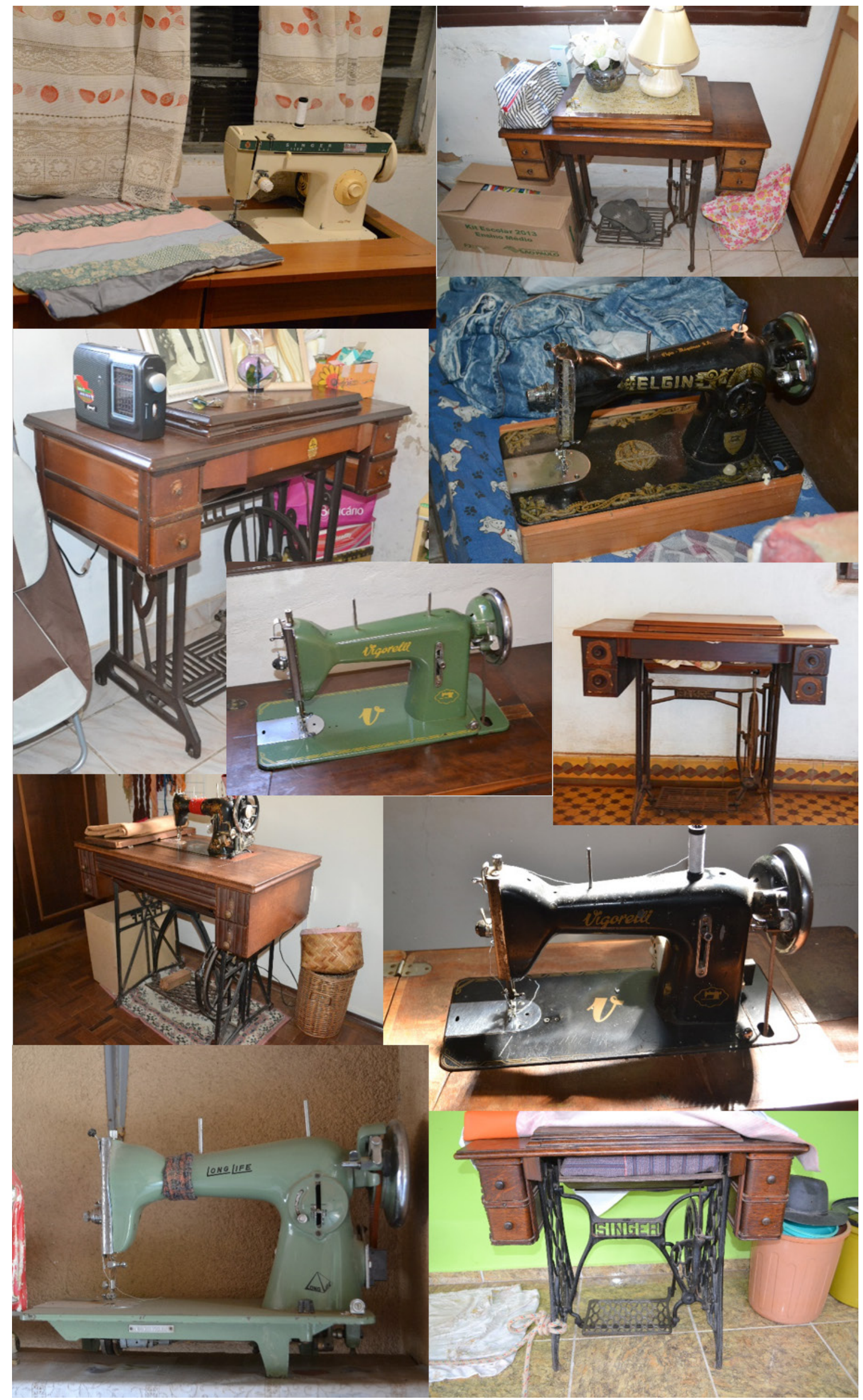


31. Moedor de café

O moedor de café foi encontrado em algumas residências, mas só em uma delas era realmente utilizado em sua função original. Nas demais, pudemos observar o moedor como enfeite de parede. Em um dos casos, o objeto fica guardado num quartinho atrás da casa, que funciona como depósito, e não é utilizado com frequência, mas seu dono não se desfaz dele por se tratar de uma relíquia, lembrança "dos bons tempos em que morava no sítio".

Está relacionado à qualidade do café, já que existe uma percepção de que o café moído na hora é mais saboroso.

É um objeto feito de ferro fundido, absolutamente durável, fácil de usar e intuitivo. 

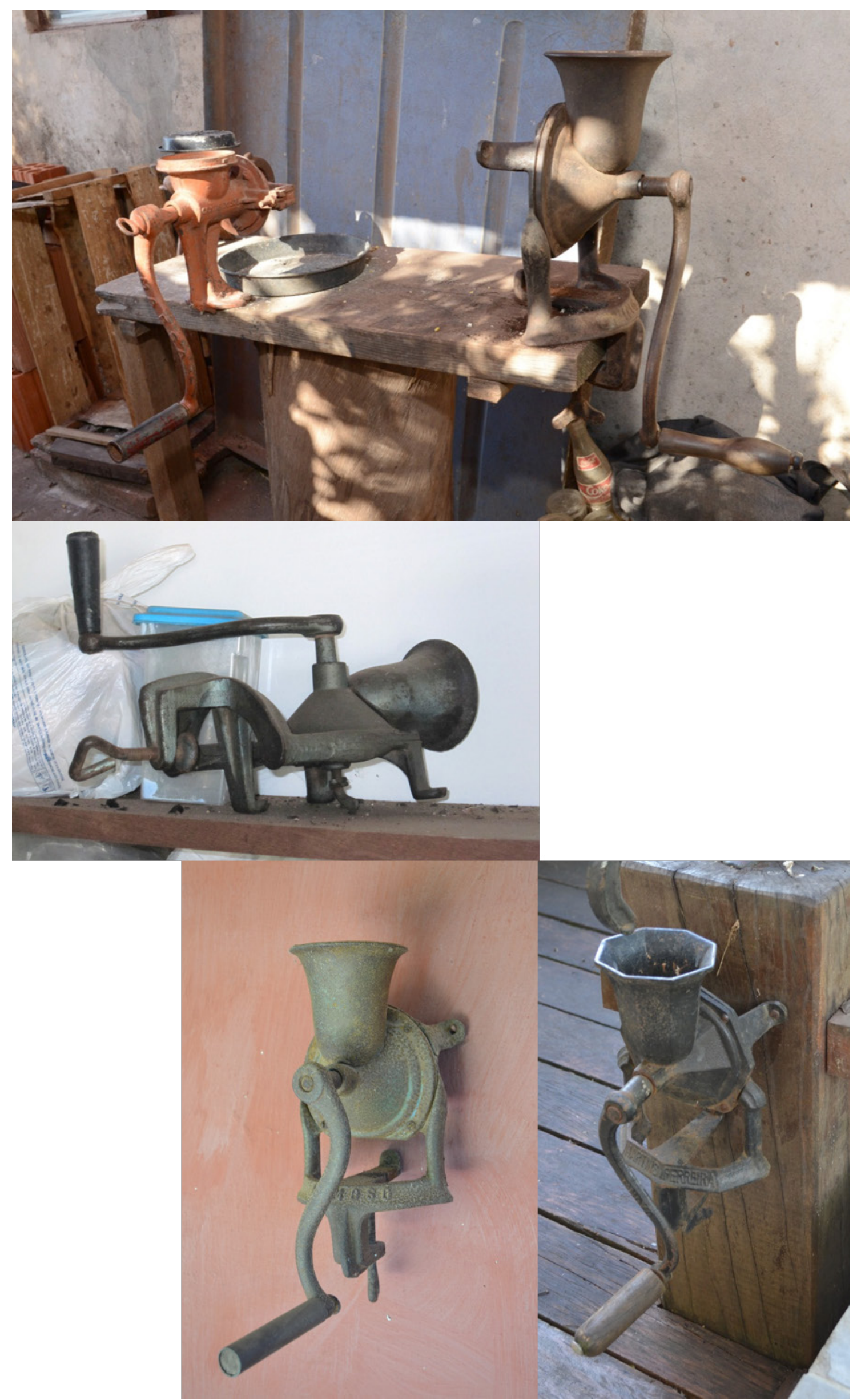


\section{Moedor de carne}

O moedor de carne é uma herança do passado rural de algumas das famílias visitadas.

Utilizado essencialmente no preparo de linguiça, quando se abatia um porco no sítio, tem sua utilidade reduzida para aqueles que hoje moram na cidade. O saber fazer linguiça é outro conhecimento transmitido de modo oral.

É um objeto feito de ferro fundido, absolutamente durável, fácil de usar e intuitivo.

Em uma das residências visitadas, fica exposto sobre uma prateleira de alvenaria da casa, junto a uma coleção de objetos de ferro fundido como ferro a carvão, moedor de café, panelas e outros objetos. 

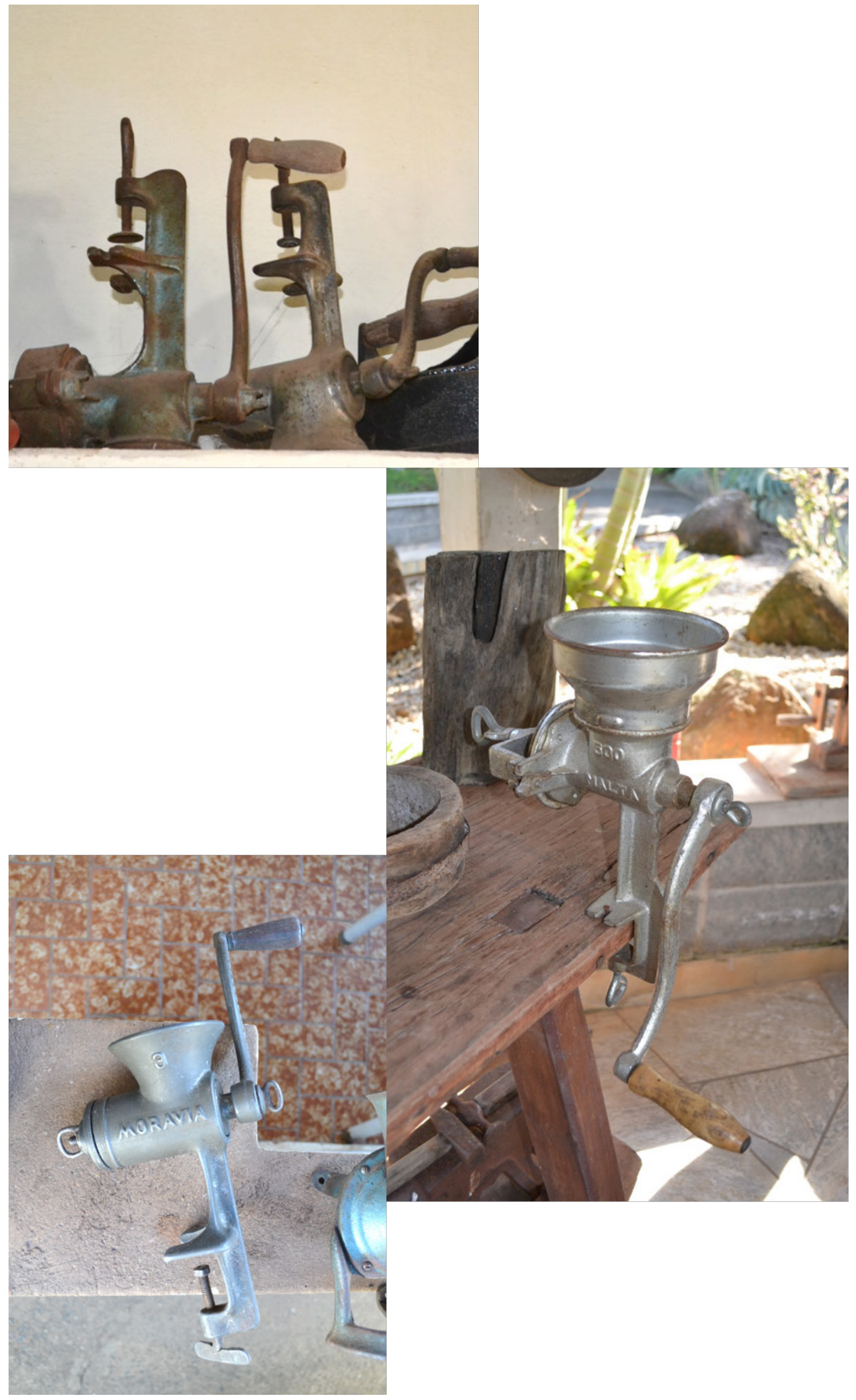


\section{Panela de ferro}

As panelas de ferro aparecem em todas as residências onde há fogão a lenha ou nas quais os moradores vieram de uma outra que, anteriormente, possuía tal tipo de fogão.

Estão associadas a valores como qualidade e durabilidade. Sua parede espessa retém o calor e mantém a comida aquecida sobre o fogão a lenha por mais tempo.

Existe a crença de que o feijão feito na panela de ferro é mais saboroso, além de ser melhor para a saúde, do que o feito em panelas de alumínio, uma vez que ela "libera o ferro".

Extremamente duráveis, muitas são herança dos pais, já falecidos há muitos anos. 


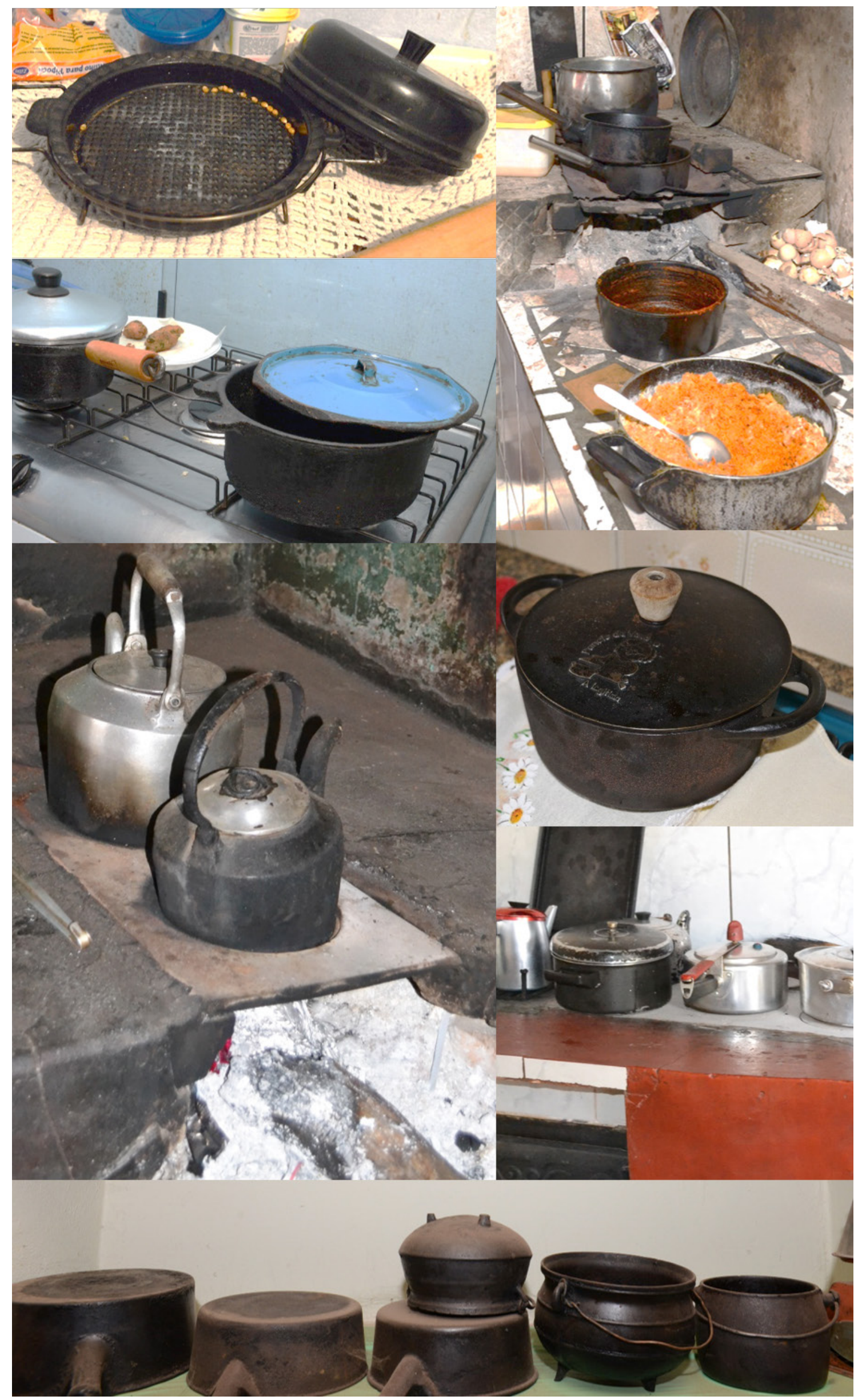




\section{Paneleiro}

Os paneleiros variam de forma e posição nas casas visitadas, porém, o que nos chamou a atenção foi o fato das panelas ficarem expostas por meio destes dispositivos.

Pudemos observar diferentes soluções em termos formais e de materiais: suportes verticais piramidais (paneleiro de chão) feitos de ferro esmaltado; prateleiras de madeira ou compensado pintado, suspensas com mãos-francesas sobre a pia da cozinha com as panelas dispostas lado a lado; estantes de aço ao lado do fogão a lenha repletas de panelas. Observamos ainda um "tampeiro": espécie de suporte de tampas de panelas feito de madeira pintada.

Em todos os casos, panelas e assadeiras de alumínio cuidadosamente areadas ficam expostas no ambiente de cozinha. 


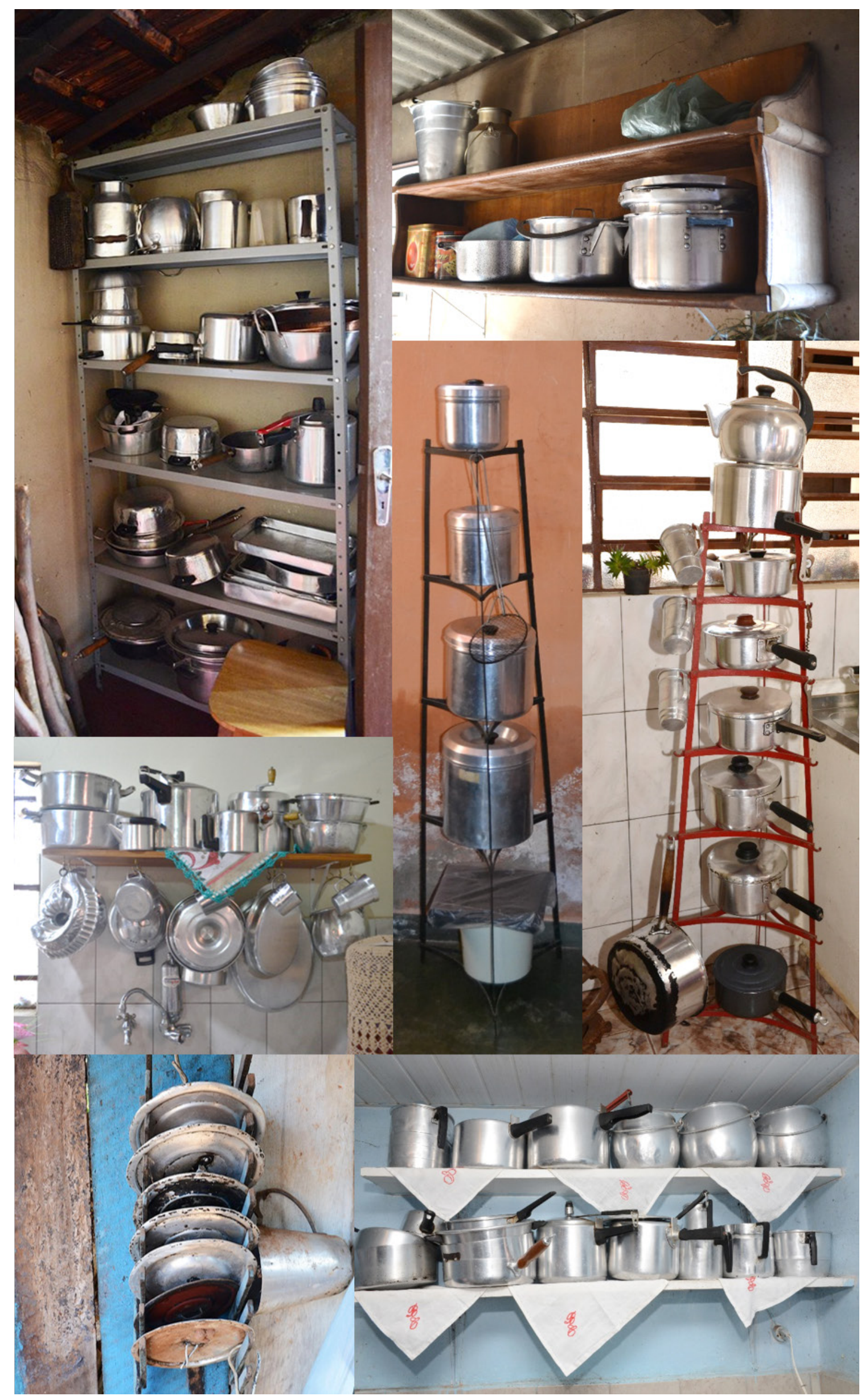




\section{Pano de prato pintado à mão com "bico de crochê"}

Os panos de prato, também chamados de guardanapos, habitam as cozinhas da maioria das casas visitadas e apresentam certas peculiaridades: normalmente feitos a partir de sacos de algodão alvejados reaproveitados, ganham decoração em motivos de flores e frutas pintadas à mão e barrado de crochê (chamado de bico) em seu arremate. Em alguns casos, nota-se maior incidência do trabalho de crochê no centro do pano, o que caracteriza sua função mais como enfeite do que pano utilitário.

Podem ter sido feitos pela própria moradora ou comprados em bazares e feiras. Alguns foram presentes de quem os pintou, o que demonstra especial reverência.

São comumente usados para cobrir a geladeira e a tampa de vidro do fogão após a arrumação da cozinha. Costumam ficar pendurados próximos à pia da cozinha, na tampa do fogão ou ainda no puxador do forno. 


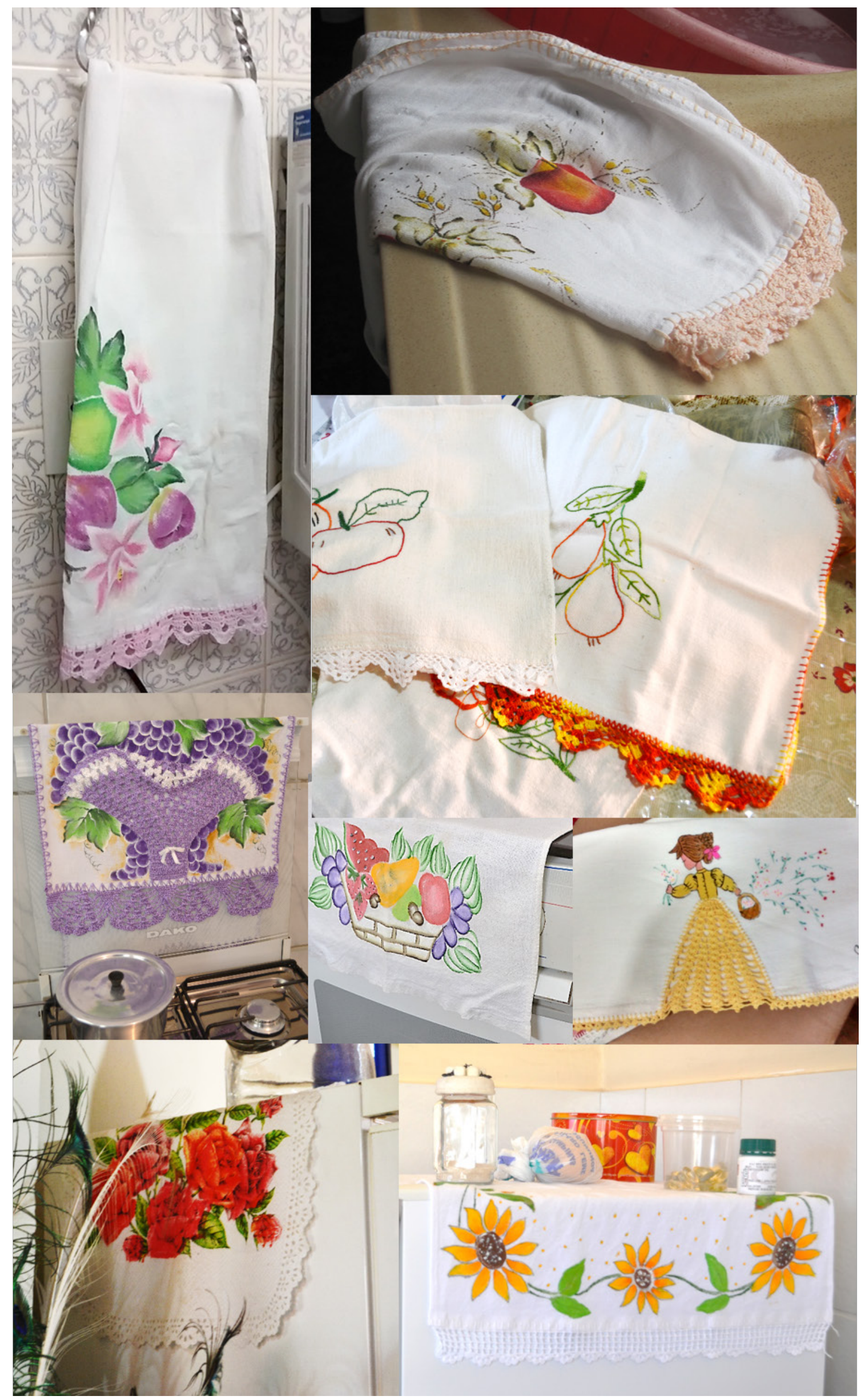




\section{Peneira para grãos}

A peneira para grãos é um objeto específico das residências com forte ligação com o ambiente rural. Feita de malha de ferro bem aberta num bastidor de madeira, é utilizada para secar café em pequenas quantidades, bem como outros grãos colhidos na roça (milho, feijão, amendoim) ou comprados a granel no mercado local. 


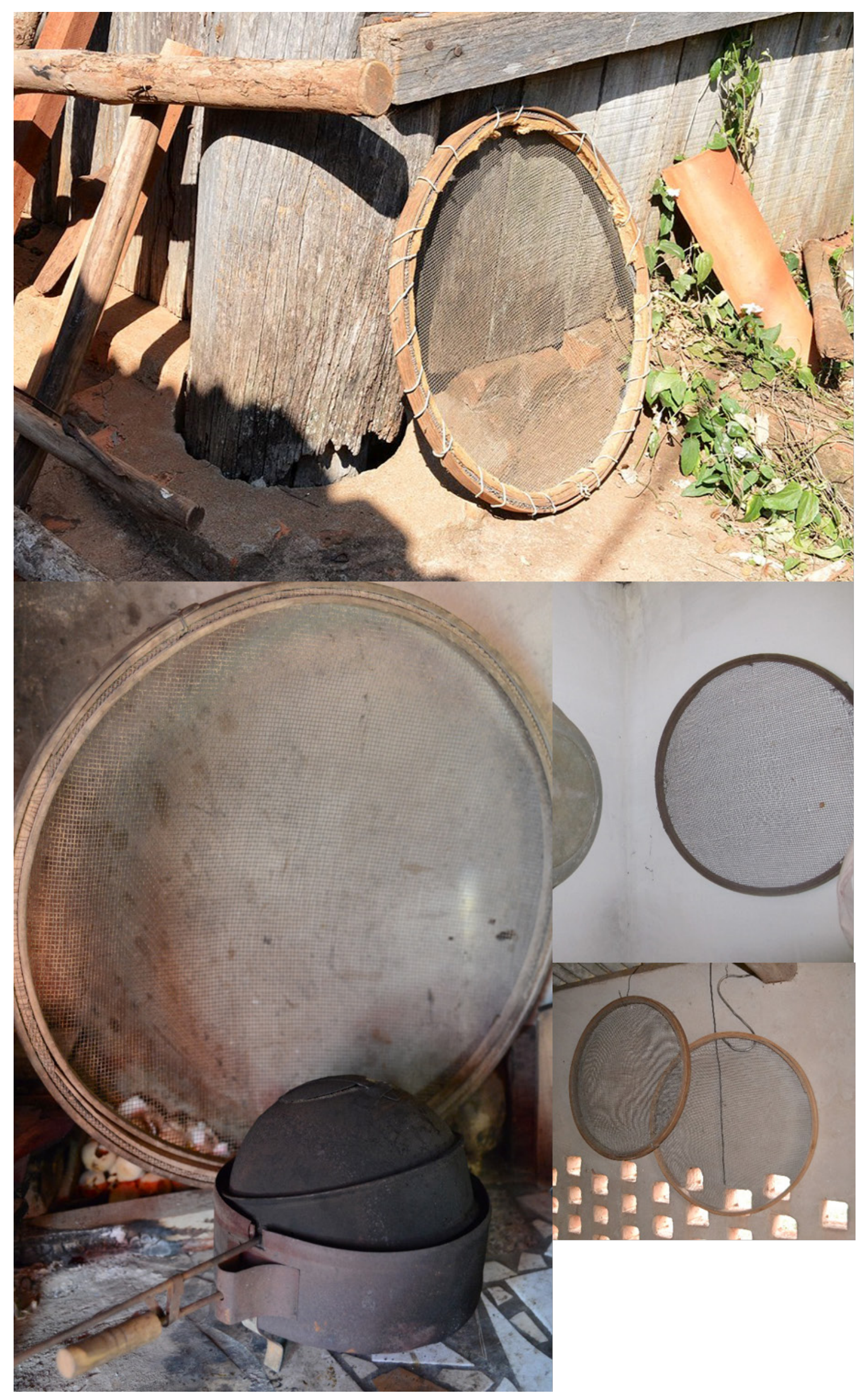




\section{Pilão}

O pilão é um objeto rústico feito de madeira maciça entalhada, utilizado para triturar certos tipos de grãos no preparo de alimentos sazonais.

Durante as visitas a campo (realizadas em julho de 2014), observamos, em duas ocasiões, o uso do pilão para triturar a semente do urucum a fim de extrair seu sumo vermelho para o preparo do colorau, condimento utilizado no tempero de carnes e de outros pratos por sua capacidade de realçar a cor dos alimentos.

Mesmo quando pouco utilizado, o pilão não é dispensado. Em alguns casos, enquanto não está em uso, serve de enfeite, transformado em suporte para um arranjo de penas de pavão, por exemplo. Em outros, faz as vezes de mesinha lateral, tendo sua parte superior côncava utilizada para apoiar uma fruteira. 


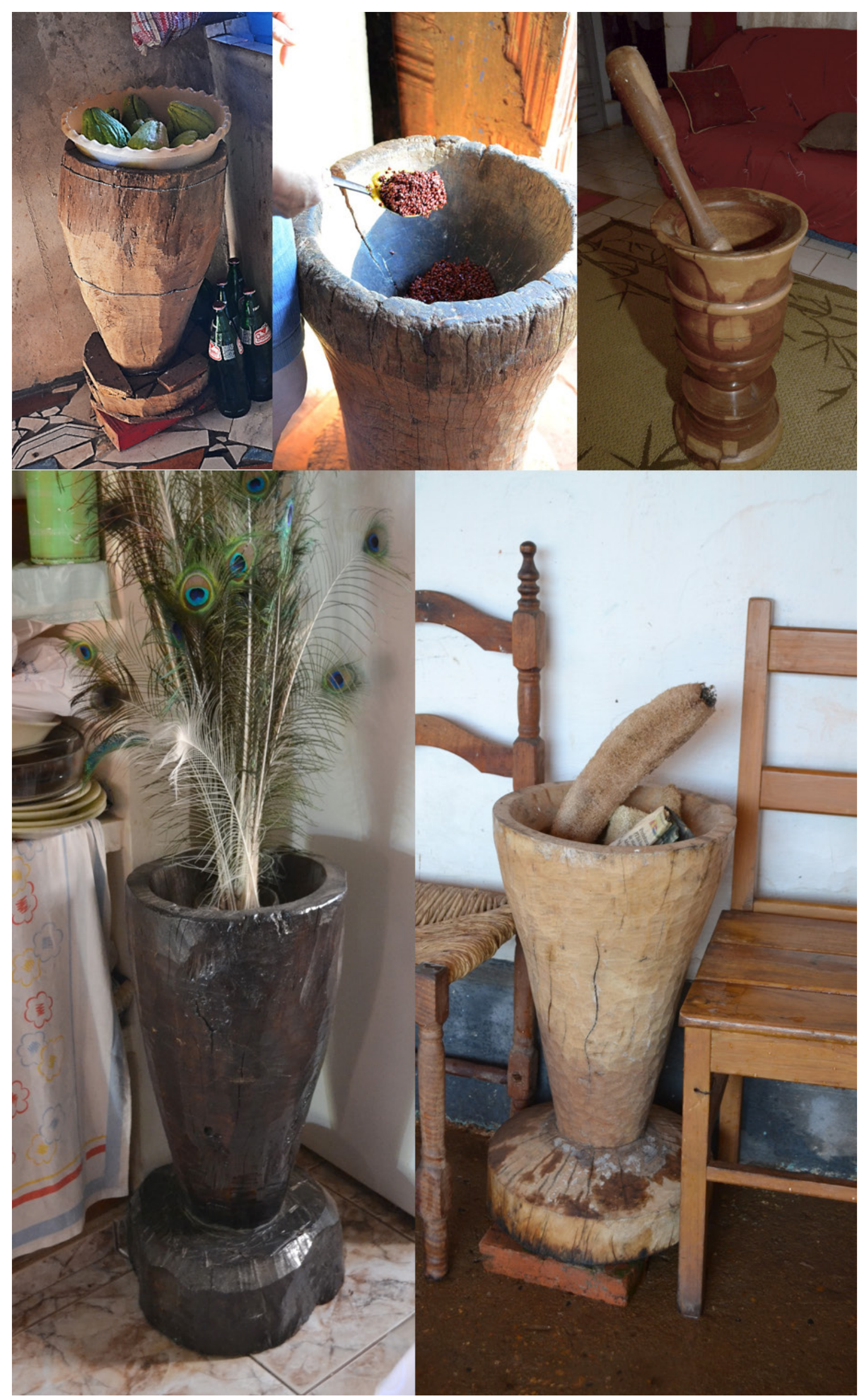




\section{Porcelanas decoradas "desparceiradas"}

Este item não corresponde a um artefato, mas a um apanhado deles: objetos de porcelana de diferentes modelos, padrões e estampas, que convivem lado a lado no cotidiano das residências.

O que chamou-nos a atenção para este item foi o fato de ser irrelevante para estas famílias a louça utilizada não pertencer a um só jogo de jantar (ou serviço de jantar), o que seria recomendado pelos padrões estéticos das classes mais abastadas. Ao invés disso, o que se vê é a indiscriminada utilização da louça disponível na casa, independentemente de qualquer noção de jogo ou conjunto.

Sua discrepância de estampas confere uma linguagem visual interessante aos conjuntos, além de indicar algumas tendências em termos de motivos ou temas relevantes no design de superfície deste tipo de artefato. 


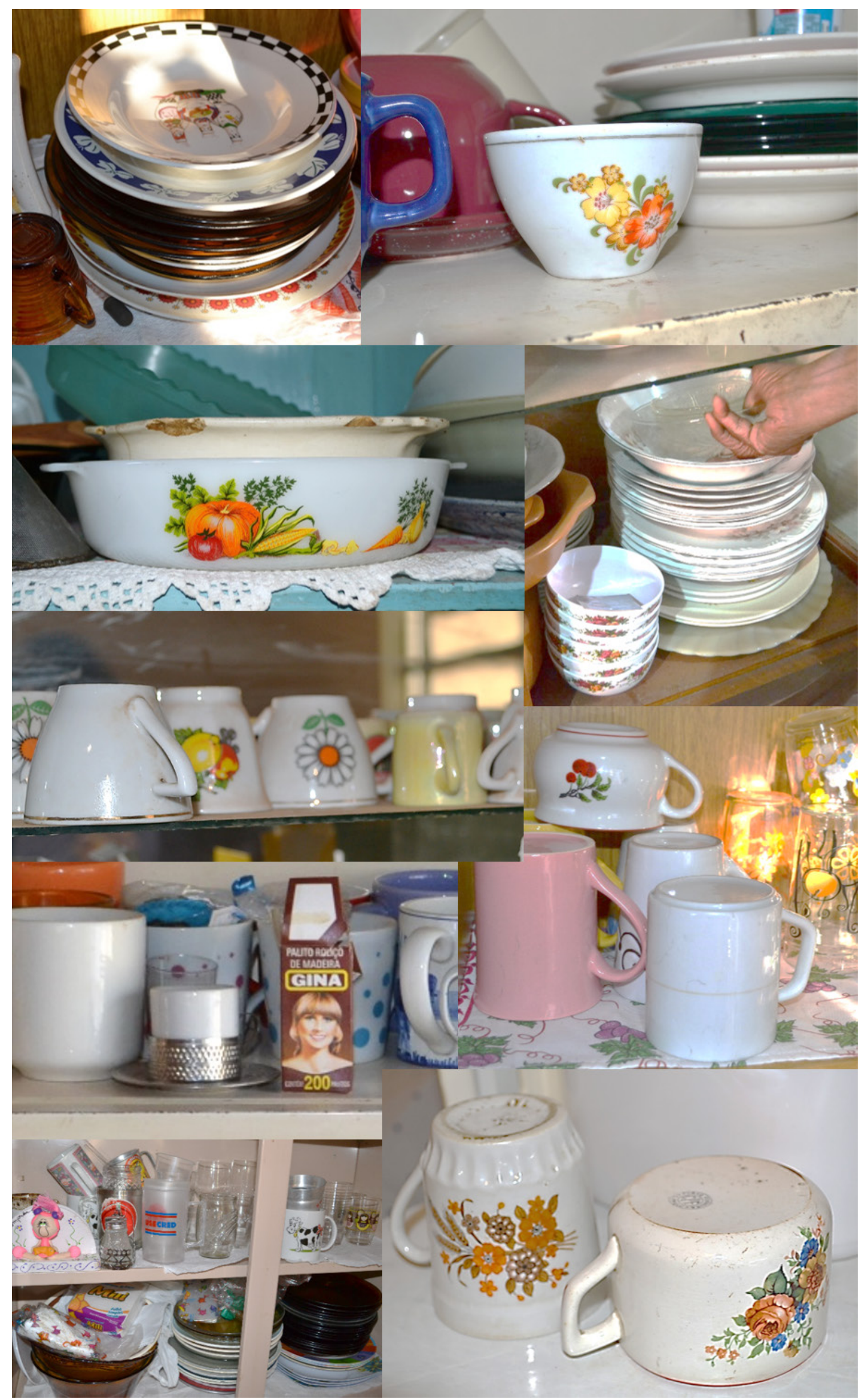




\section{Potes de vidros decorados (bombonière)}

"Casa de vó tem sempre coisa gostosa." Com essa declaração, obtida em um relato de memória, saímos a campo e nos deparamos com diferentes soluções, do ponto de vista formal, para o que se alude na citação acima. Encontramos bombonières "bico de jaca"; vidros com tampa de rosquear decorados com tecido, massa de biscuit ou crochê, criações de moradoras com suas habilidades artesanais; e, simplesmente, potes de vidro liso, com ou sem tampa, repletos de balas, bombons, biscoitos e outras guloseimas.

O que há de comum em todos os casos é o público a quem se destina o seu conteúdo: os netos. e Botucatu. Registros fotográficos da autora, 2014. 


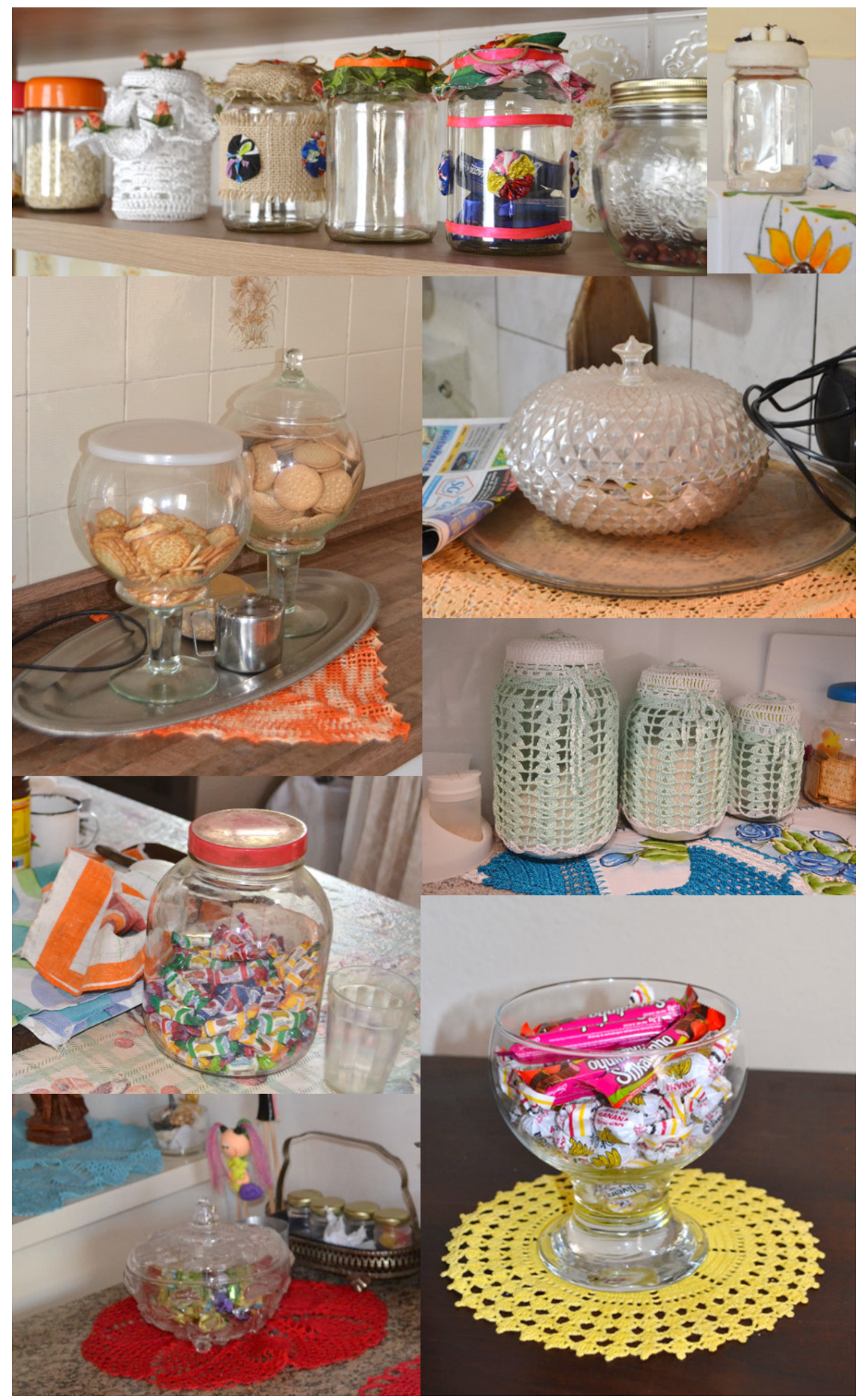




\section{Prato de porcelana de enfeite}

Pudemos observar alguns pratos de porcelana utilizados como enfeite, tanto na sala de jantar quanto na cozinha. Alguns aparecem em suportes próprios, sobre a prateleira de um móvel, enquanto outros são pendurados diretamente na parede.

Os motivos variam entre flores e paisagens, podendo apresentar algumas frases com passagens bíblicas. Os mais valorizados são pintados à mão e apresentam técnicas elaboradas de pintura em porcelana, com rosas e outros motivos ricos em detalhes. Outros são industrializados, produzidos por meio de decalque, e não desfrutam da mesma reverência dos artesanais.

Uma depoente relatou que sua predileção por pratos de porcelana na parede se deve à sua família portuguesa, aludindo a uma tradição lusitana. 


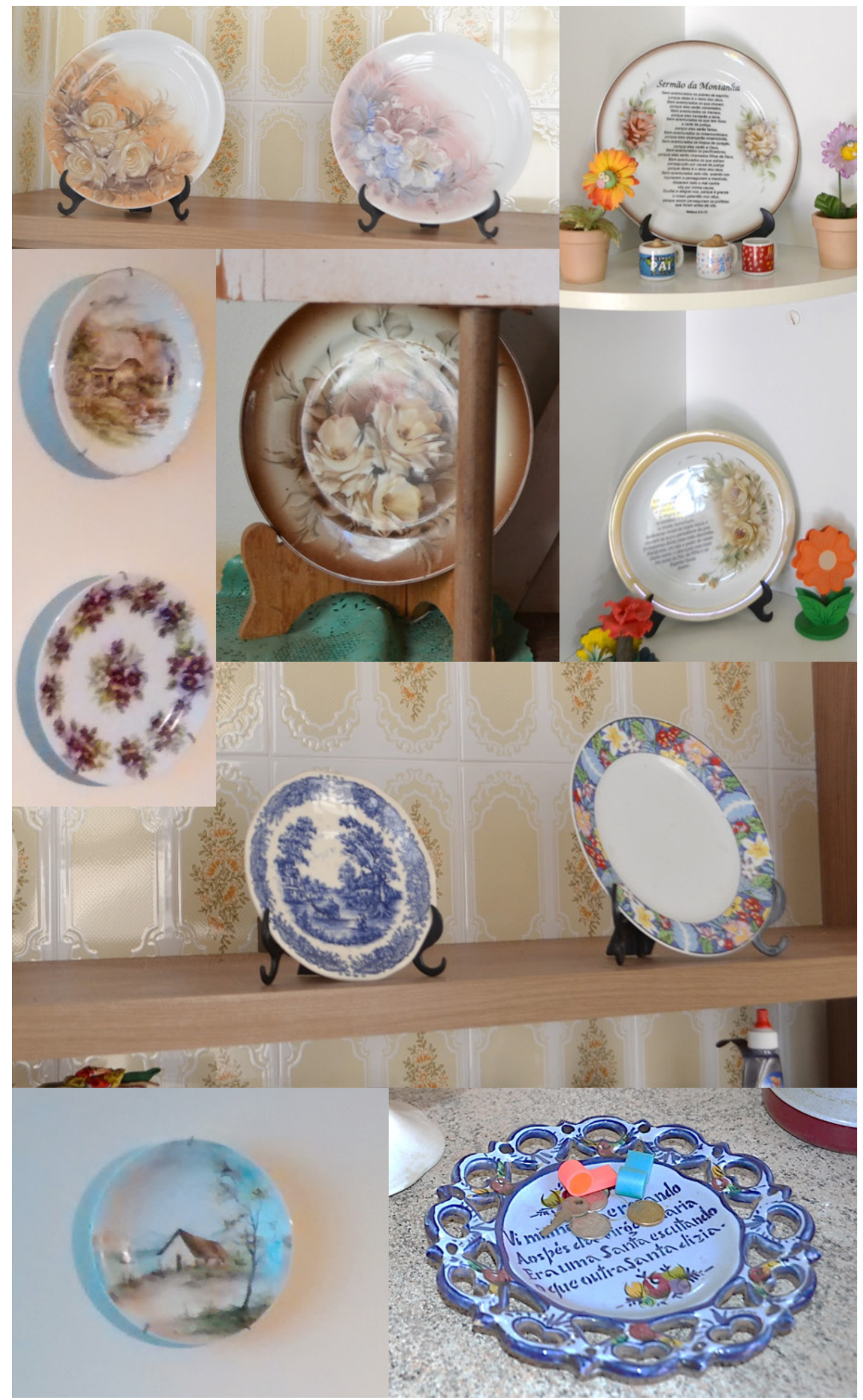




\section{Rádio}

Em algumas residências visitadas, pudemos observar a presença do rádio, especialmente na cozinha. Os aparelhos encontrados diferem completamente uns dos outros em termos de linguagem, marca, idade (um deles tem mais de 30 anos de uso), como também do ponto de vista funcional, sendo que um aparelho também toca $C D$ e fita $K 7$, e dois são rádio relógios.

Nossa intenção em incluir este artefato no estudo não reside em seus aspectos sintáticos, uma vez que, por se tratar de um aparelho eletrônico, tende a obedecer outros padrões de referência estética. O que interessanos aqui é revelar a presença do rádio em algumas das residências visitadas e sua relação semântica: "faz companhia de manhã enquanto estou na cozinha" - relata uma senhora entrevistada, moradora de Piracicaba. As irmãs de Limeira, que moram num distrito rural, costumam acompanhar a missa pelo rádio aos domingos e enviam músicas para parentes que moram próximo e também acompanham os mesmos programas. 


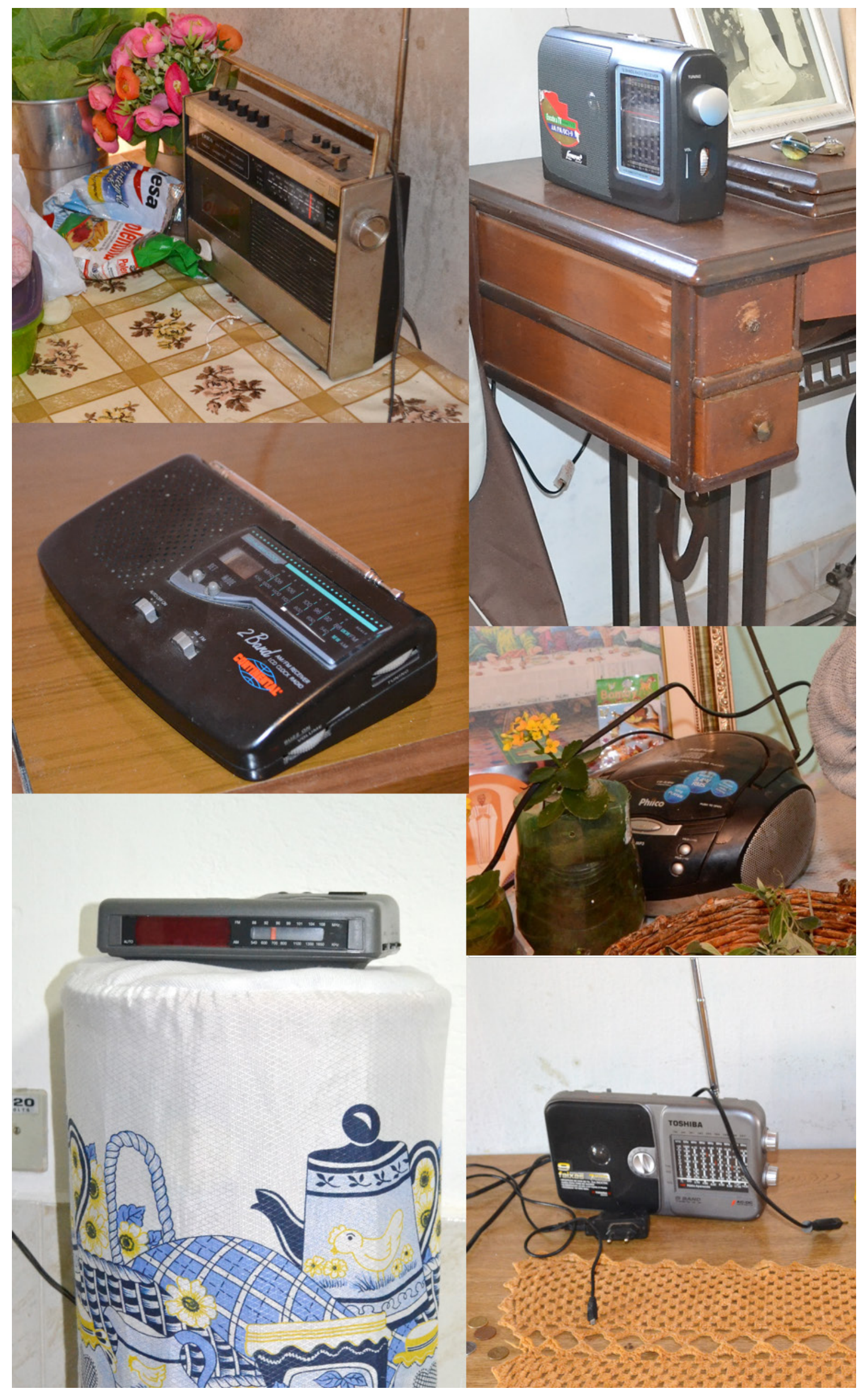




\section{Relicários (oratórios) de santos}

Os relicários são locais para guardar relíquias - que, neste caso, são imagens de santos -, são suportes feitos especialmente para esse fim. Também chamados de oratórios por servirem para as orações, são pequenos armários ou capelas habitadas por santos diversos. Podem ser encontrados embutidos na alvenaria com uma portinha de vidro, fazendo parte da casa; ou feitos toscamente pelo morador, de madeira pintada, ou mais elaborados, também de madeira, imitando a igreja matriz da cidade. Em uma das ocasiões, encontramos uma peça feita por um dos filhos da moradora, em forma de capela, a partir de embalagens de maços de cigarro, pintados de branco.

Os relicários ou oratórios, muitas vezes, compõem uma espécie de altar, juntamente com outras imagens avulsas, para rituais religiosos domésticos, herança caipira dos bairros distantes das paróquias mais próximas.

Os santos mais comuns são Nossa Senhora Aparecida e São Benedito. Existe uma crença de que se deve colocar café junto à imagem deste santo, em forma de oferenda. Temos o relato de um casal de devotos seus que disputa quem acorda mais cedo para fazer o café e ter a honra de fazer a oferenda para o santo: "O São Benedito tem que pôr café todo dia; ah, ele gosta. O Ademar levanta mais cedo e coloca o café antes de mim... eu fico uma fera!"

Quadro 42. Relicários ou oratórios com imagens de santos confirmam a religiosidade doméstica. Presentes em residências de Laranjal Paulista, Monte Aprazível, São Luís do Paraitinga, Piracicaba e Botucatu. Na segunda imagem, de cima para baixo e da esquerda para a direita, nota-se a peça em forma de capela feita com embalagens de maços de cigarro pintados de branco. Registros fotográficos da autora, 2014. (Última imagem, de cima para baixo e da esquerda para a direita: foto de Eliete Soares) 


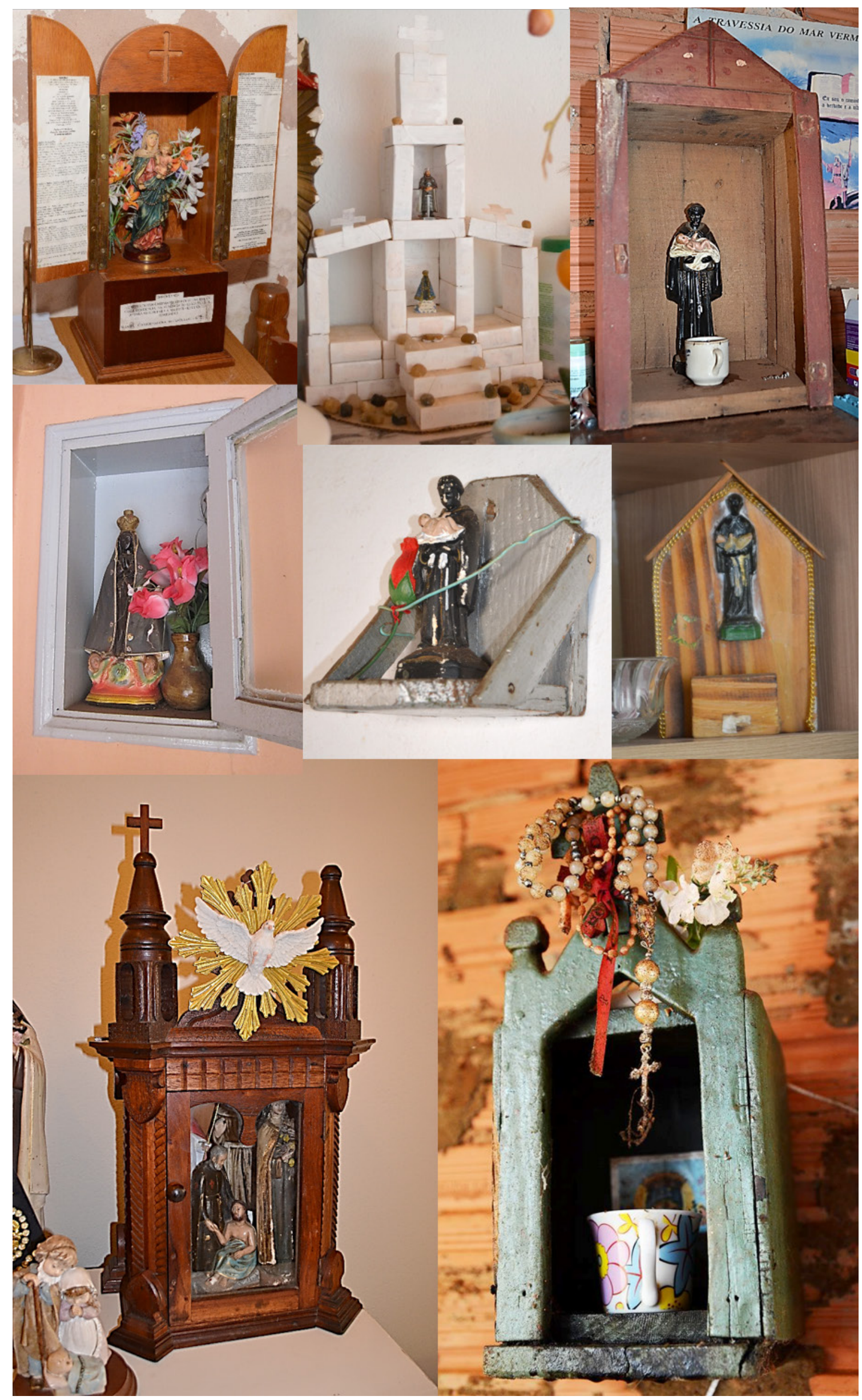




\section{Retratos antigos de parede}

Os retratos antigos estão presentes em todas as residências sobre móveis em porta-retratos ou pendurados na parede como quadros. Este segundo grupo nos chama a atenção por sua peculiaridade: são retratos de parentes já falecidos, em molduras trabalhadas, com formato ovalado ou com cantos arredondados, em gesso ou madeira pintada, com pequenos adornos aplicados ou acabamentos especiais. Muitas destas fotografias são de baixa qualidade, em preto e branco, às vezes colorizadas.

Um relato de memória de um entrevistado marcou-nos com a seguinte observação: "Tenho na memória os quadros de parede com fotos antigas e no formato ovalado, em tom amarelo e com moldura em madeira marrom. Sentimento religioso, pois eram imagens de pessoas desconhecidas, mas próximas pelo lastro familiar. As fotos eram dos antepassados e remetiam a um tempo desconhecido. As imagens despertavam curiosidade, incertezas e a sensação de pertencimento."

Pudemos observar a importância destes retratos nas casas, sempre colocados em locais de destaque na sala principal.

Em uma ocorrência, os retratos são de antepassados tão longínquos que o entrevistado não sabe dizer quem é a pessoa, que falecera muito antes dele nascer. Mesmo assim, o retrato continua na parede, pois acompanha a família há muito tempo e "deve continuar onde sempre esteve". 


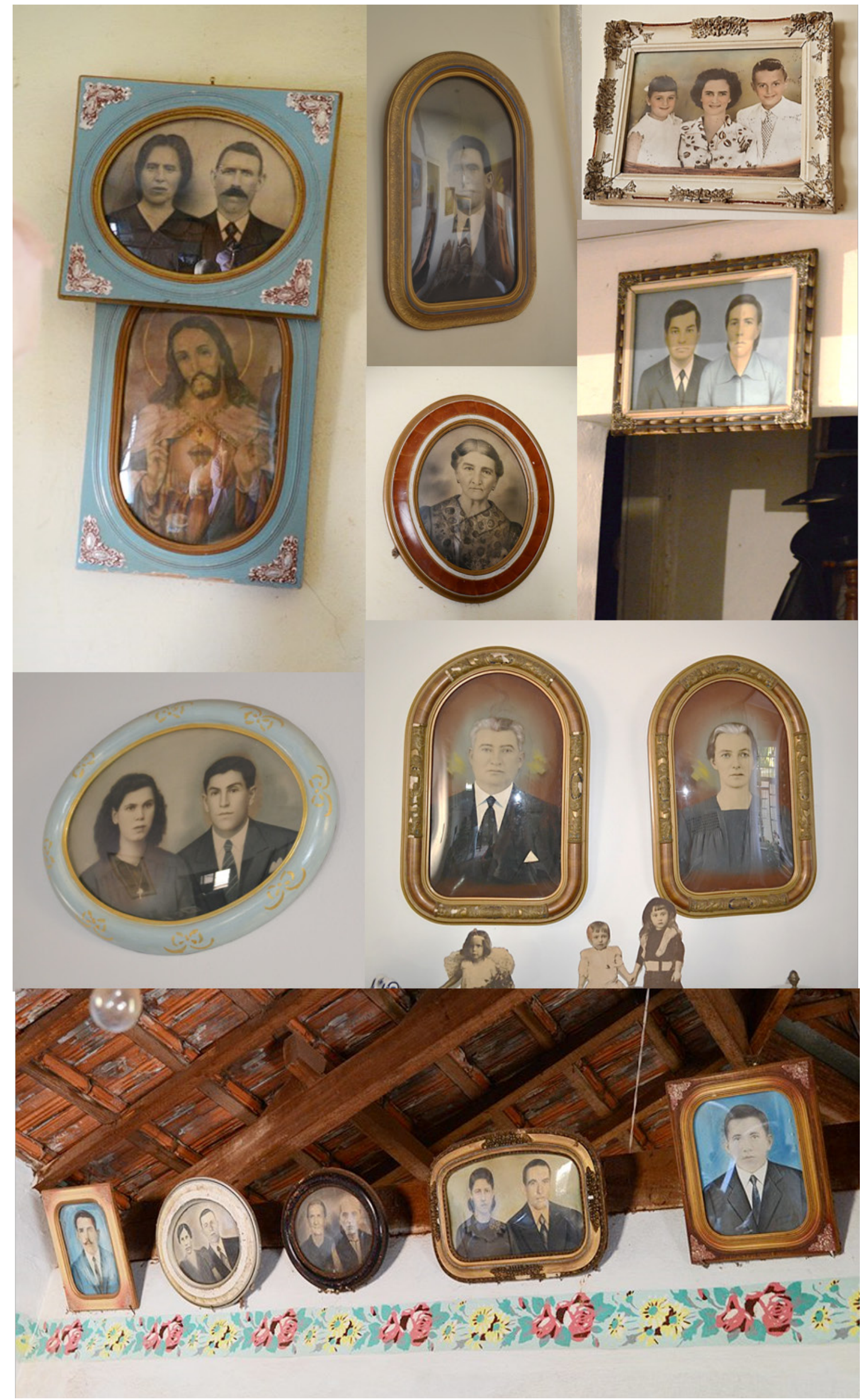




\section{Retratos de santos e de Cristo}

Assim como os retratos de familiares falecidos, as imagens de santos e de Cristo aparecem em molduras trabalhadas, ovaladas e de cantos arredondados, penduradas na parede de salas e quartos, como um sinal de proteção.

Nota-se uma tendência em dispor a imagem de Cristo sobre a porta de passagem, como que para receber uma benção a cada vez que se passa sob aquela imagem.

As imagens mais comuns são do Sagrado Coração de Jesus e de Maria.

Algumas imagens aparecem com suas cores originais desbotadas pelo tempo que ficaram expostas à luz. Isso Ihes confere um tom amarelado, criando uma paleta típica.

Em uma residência de Laranjal Paulista, pudemos observar dois quadros idênticos com as imagens do Sagrado Coração de Maria e de Jesus pendurados lado a lado na parede da sala, um muito desbotado e o outro com as cores vivas, aparentando ser mais novo. Perguntada a respeito da duplicidade, a moradora explicou-nos que, "apesar do antigo estar desbotado, não tenho coragem de jogar fora." 


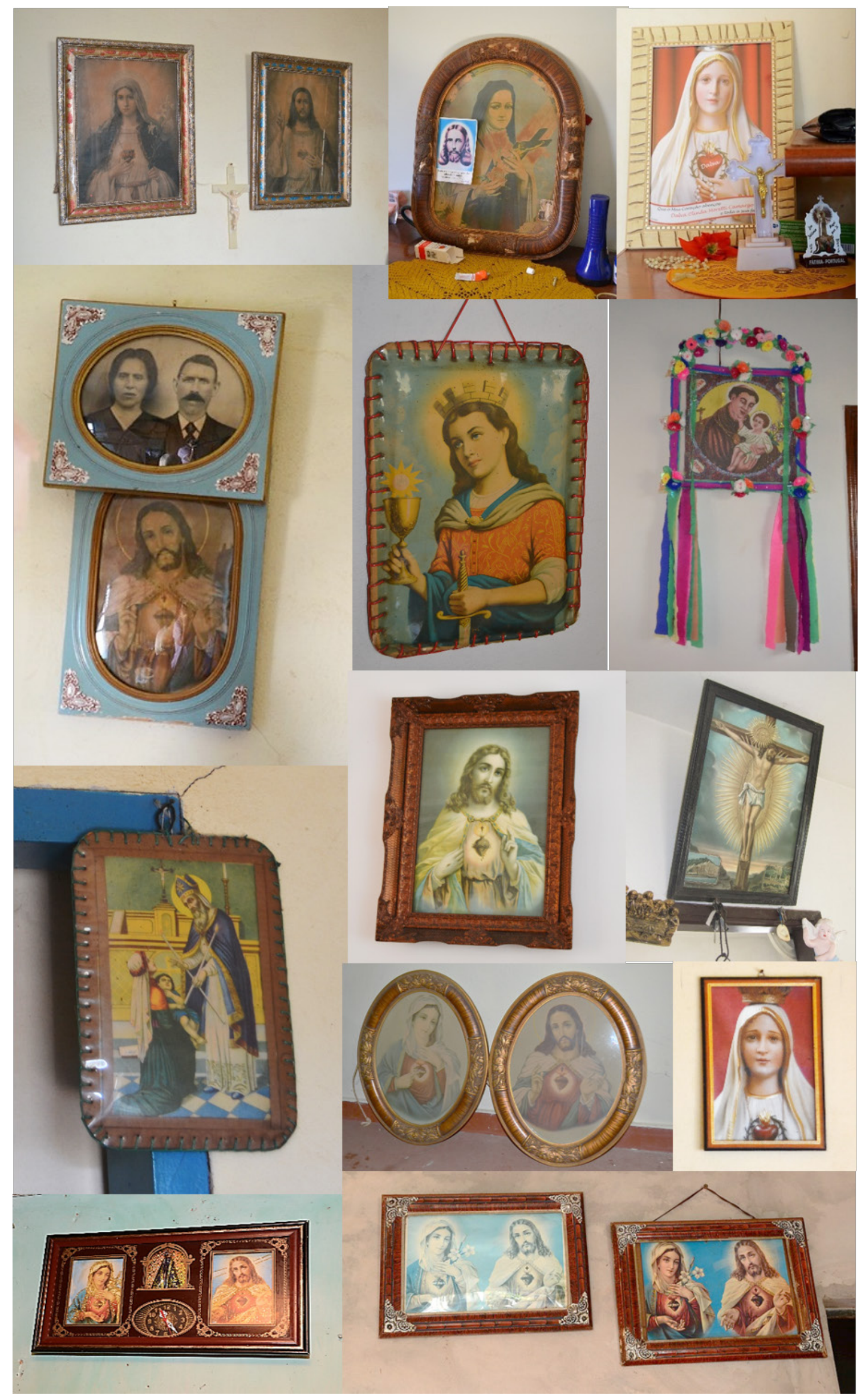




\section{Roseira}

As roseiras aparecem normalmente nos jardins frontais das casas. Notam-se variedades diferentes da planta, desde a clássica arbustiva até as silvestres, incluindo rosas miúdas trepadeiras. De cores que variam do branco ao vermelho intenso, são motivo de orgulho para a dona da casa. Em sua maioria, foram plantadas pelos moradores a partir de mudas obtidas com parentes ou pessoas conhecidas.

Abastecem os vasinhos de oferenda colocados junto aos santos. 


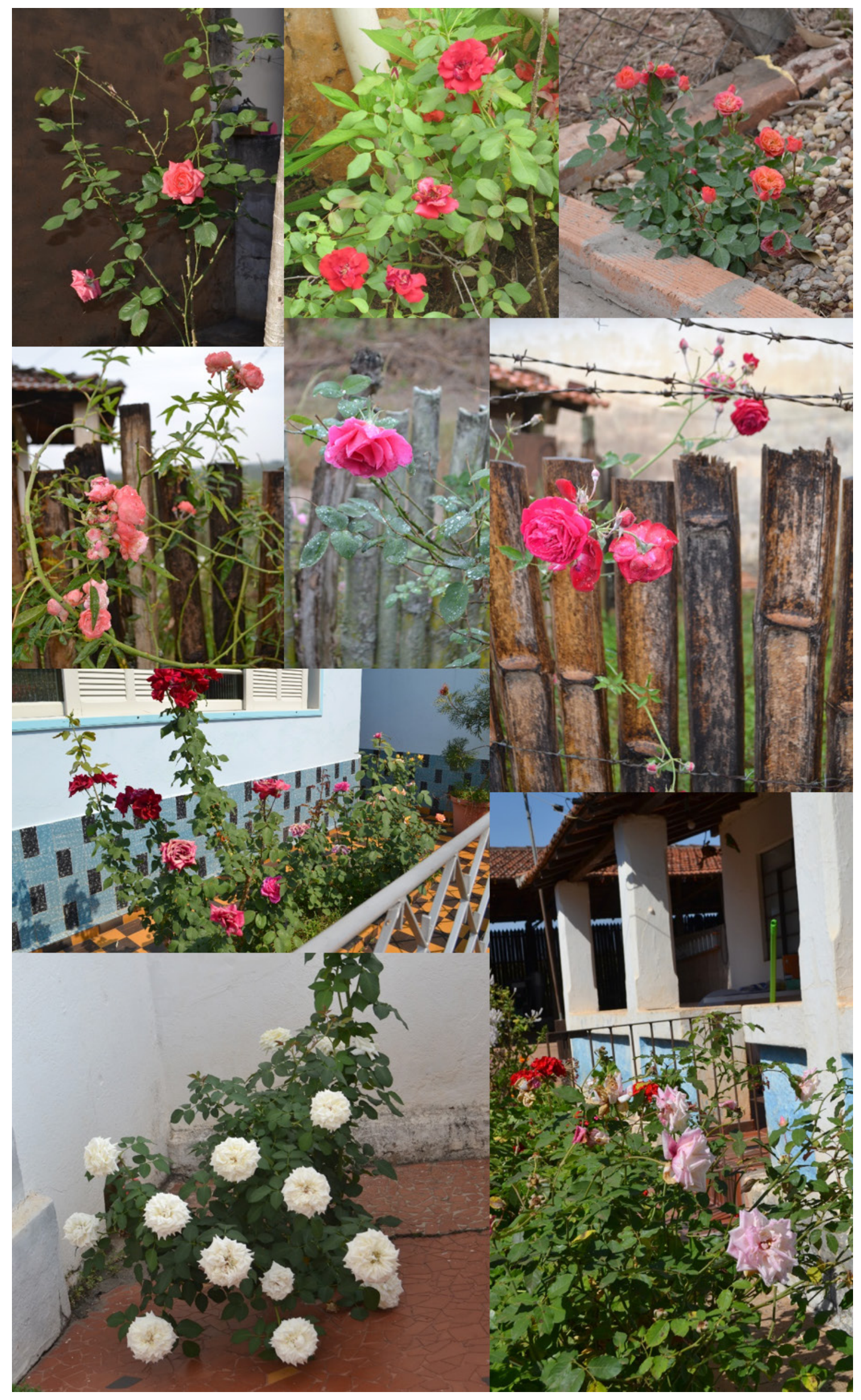




\section{Samambaia suspensa}

A samambaia paulista, cujo nome científico é Nephrolepis pectinata, é um tipo de samambaia rústica facilmente cultivada em vasos suspensos, encontrada nas áreas de entrada das residências visitadas, geralmente em varandas ou em garagens livres do sol.

Não possui nenhum outro valor simbólico associado, a não ser o prazer da moradora pelo cultivo em si, muito fácil e compensador.

Por ser uma planta cujas folhas caem em cascata, frequentemente é colocada suspensa em suportes de parede. Também é chamada de samambaia de metro. 


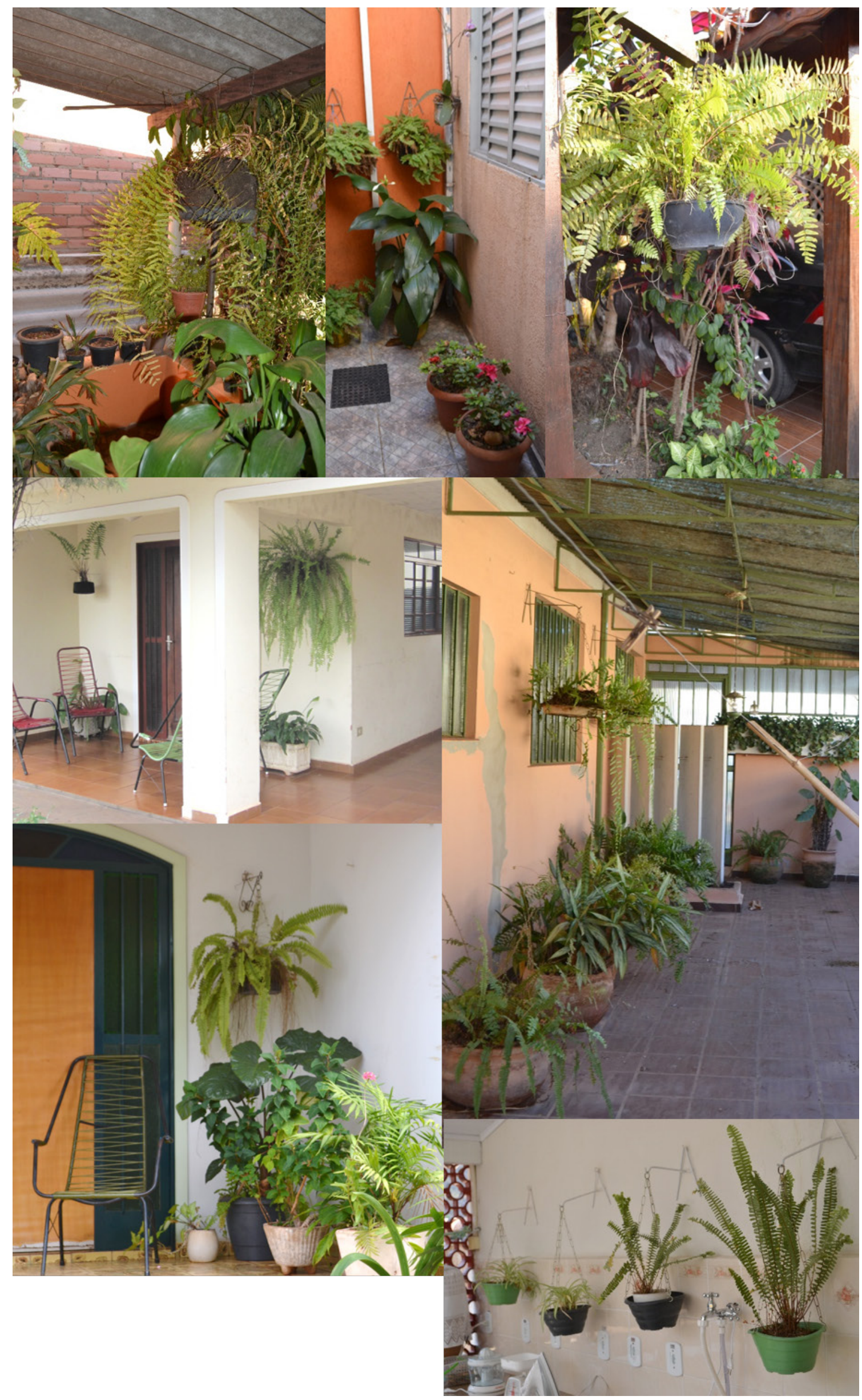




\section{Santa Ceia}

A imagem da Santa Ceia aparece em algumas residências e está ligada à benção das refeições. Por este motivo, costuma ser colocada na sala de almoço ou jantar e, de preferência, em cima do batente da porta, como uma benção a quem passa por ali.

Pode aparecer na forma de um quadro, como uma pintura, ou uma peça de gesso com acabamento sombreado. Em uma ocorrência, o quadro com a imagem também é um relógio. 

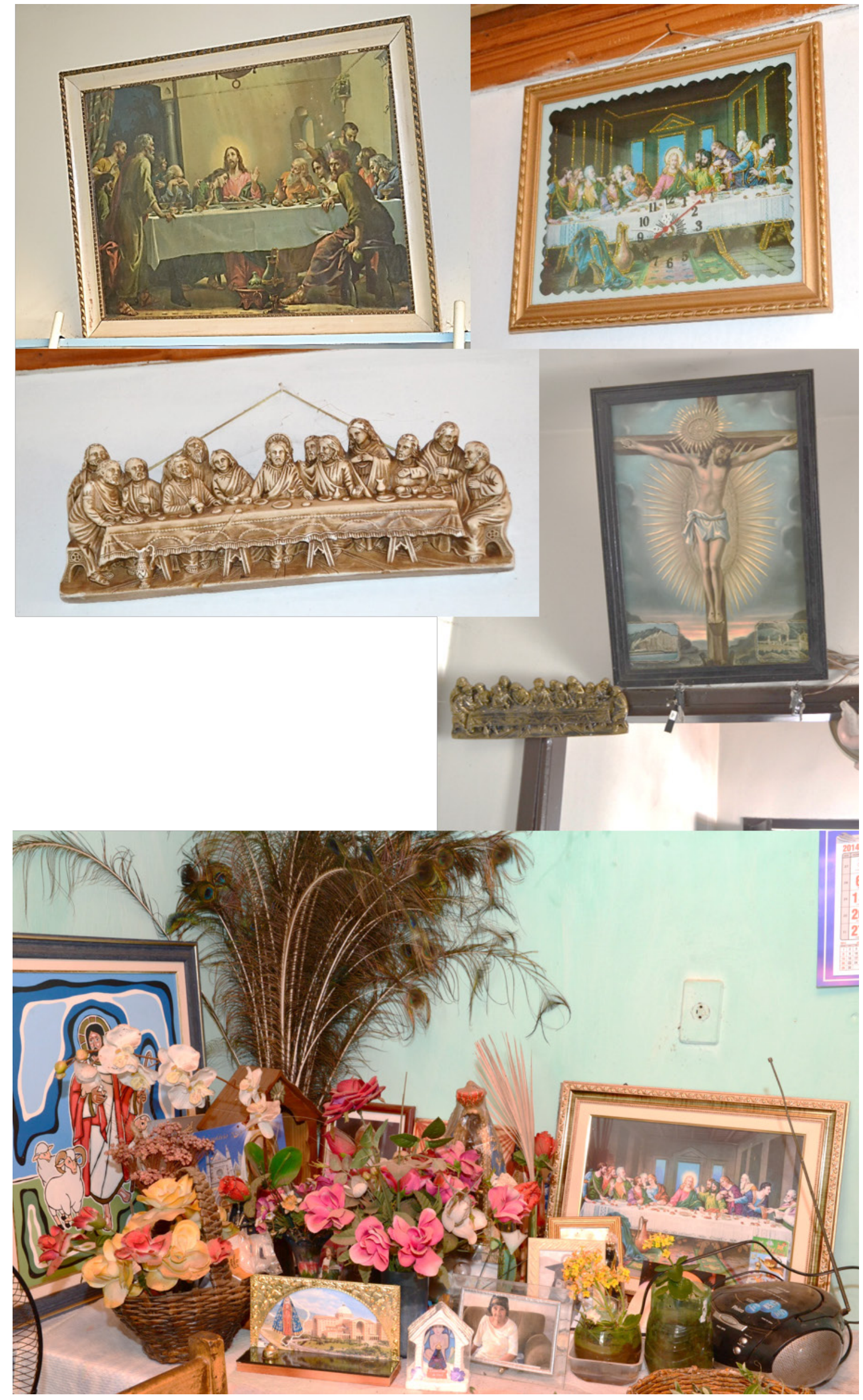


\section{Tacho de cobre}

O tacho de cobre é essencialmente funcional e sua utilidade está ligada ao preparo de doces e sabão.

Diz-se que o cobre não altera a cor dos alimentos quando cozidos. Também é usado para o preparo do sabão a partir das cinzas retiradas do fogão a lenha.

Mesmo quando pouco utilizados, os grandes tachos são mantidos pela família por gerações.

Enquanto não estão em uso, acabam sendo guardados no alto ou, quando areados, expostos como uma fruteira. São higienizados com uma mistura de sal e limão.

Em uma das residências visitadas, o tacho de cobre, que era da mãe da entrevistada, virou um revisteiro pela falta do seu uso original nos dias atuais. 


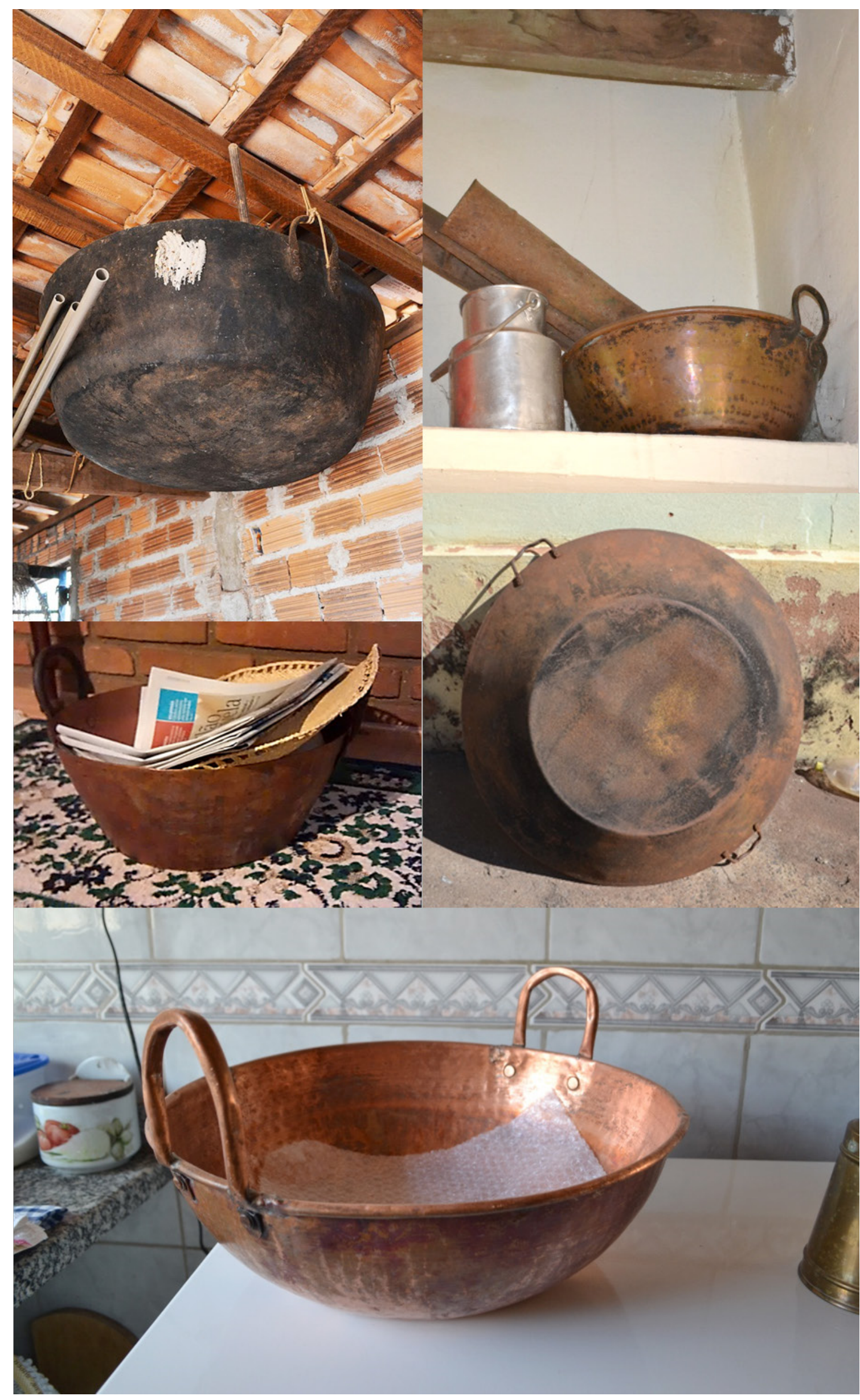




\section{Tapetinhos}

Os tapetinhos decorados encontrados nas visitas de campo diferem em termos de técnica de composição e linguagem visual. Em comum, têm a função de proteger o piso da sujeira de fora, servindo de capacho, ou proteger os pés descalços da "friagem do chão", como ao lado da cama ou no banheiro.

Podemos dividi-los em três grupos: primeiro, os tapetinhos de crochê, feitos com linha grossa de algodão (barbante), em uma, duas ou até três cores; o segundo, é tapetinhos de retalhos trançados, de malha, que são amarrados, deixando suas pontas livres, o que confere um ar irregular ao tapete, misturando-se várias cores; o último, é o dos tapetes de retalhos de algodão, de cores e estampas distintas, que são costurados formando bicos triangulares em forma de escama.

Os tapetinhos artesanais são normalmente produzidos pelas moradoras ou comprados em bazares. 


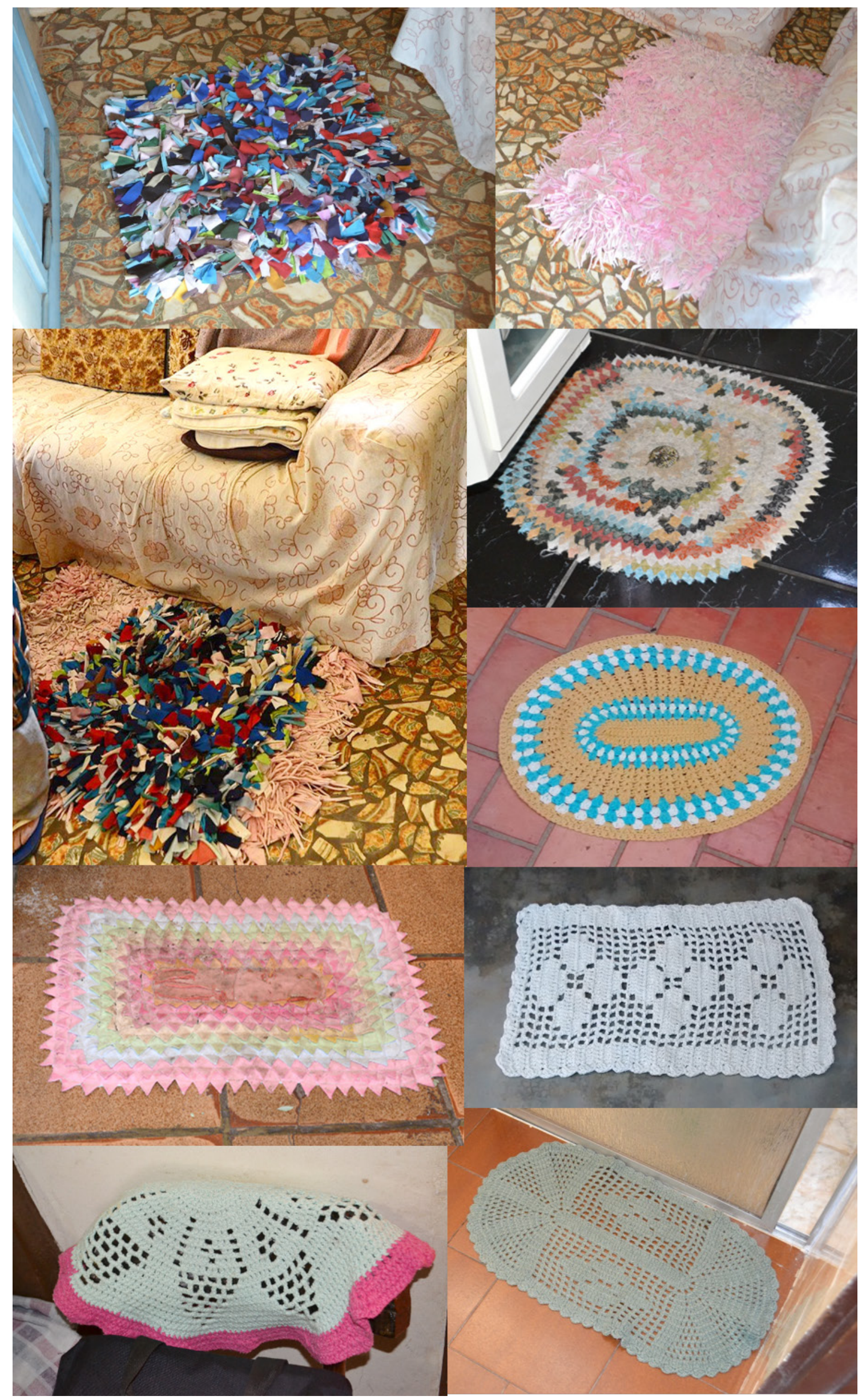




\section{Toalha de plástico decorada}

As mesas da cozinha, da área, da varanda ou da sala de jantar de grande parte das residências visitadas estão cobertas por toalhas de plástico decoradas.

Em uma profusão de estampas, frequentemente de motivos florais, as toalhas de plástico são preferidas às de tecido pela praticidade em mantê-las limpas. Uma vez que são plastificadas na face superior que fica em contato com os alimentos, as toalhas impermeabilizadas não absorvem a sujeira e são facilmente limpas com um pano úmido e detergente.

Algumas possuem uma face flanelada, o que dispensa o uso de apoio de panelas e permite que se coloque uma travessa quente sobre a mesa de madeira, por exemplo, sem danificá-la.

São compradas em lojas de plásticos, por metro, e extremamente duráveis. 


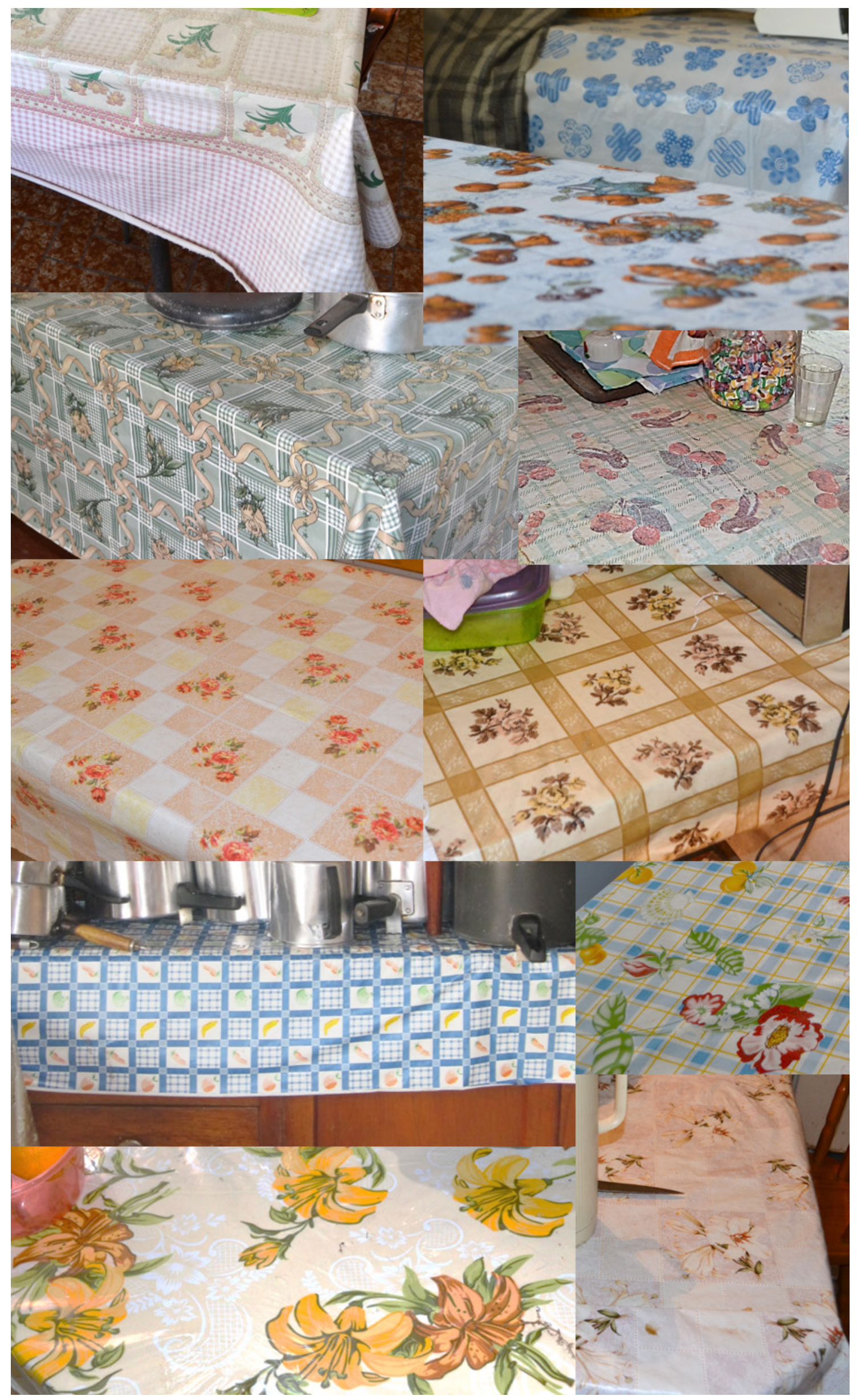




\section{Toalhinha de crochê}

As toalhinhas de crochê aparecem sob vasos de flores, telefones, travessas ou bombonières em todos os ambientes da casa, sobre mesinhas laterais, aparadores ou estantes da sala, para proteger os móveis e enfeitar o ambiente. Também aparecem em pequenos altares, embaixo de imagens de santos para emoldurálas. São utilizadas para proteger e emoldurar prateleiras de estantes repletas de pequenos enfeites, de modo a criar um "véu" em forma de meia-lua sobre o vão inferior.

Geralmente, são feitas com apenas um novelo de linha, o que significa uma produção mais econômica e rápida. São, em sua maioria, produzidas pela própria dona da casa, que aprendeu a fazer crochê com alguma parente mais velha, ou foi comprada em bazares da comunidade com o intuito de ajudar. Muitas toalhinhas foram recebidas como presente, o que parece ser um hábito entre as senhoras que fazem crochê como passatempo: na impossibilidade de expor tanta produção em casa, presenteiam os parentes.

Ouvimos o relato de uma senhora que conta ter aprendido a fazer crochê muito moça, mas que "perdeu a mão", pois quase não fazia: "o dinheiro era tão curto naquele tempo com cinco filhos pra criar que não sobrava pra comprar linha". 


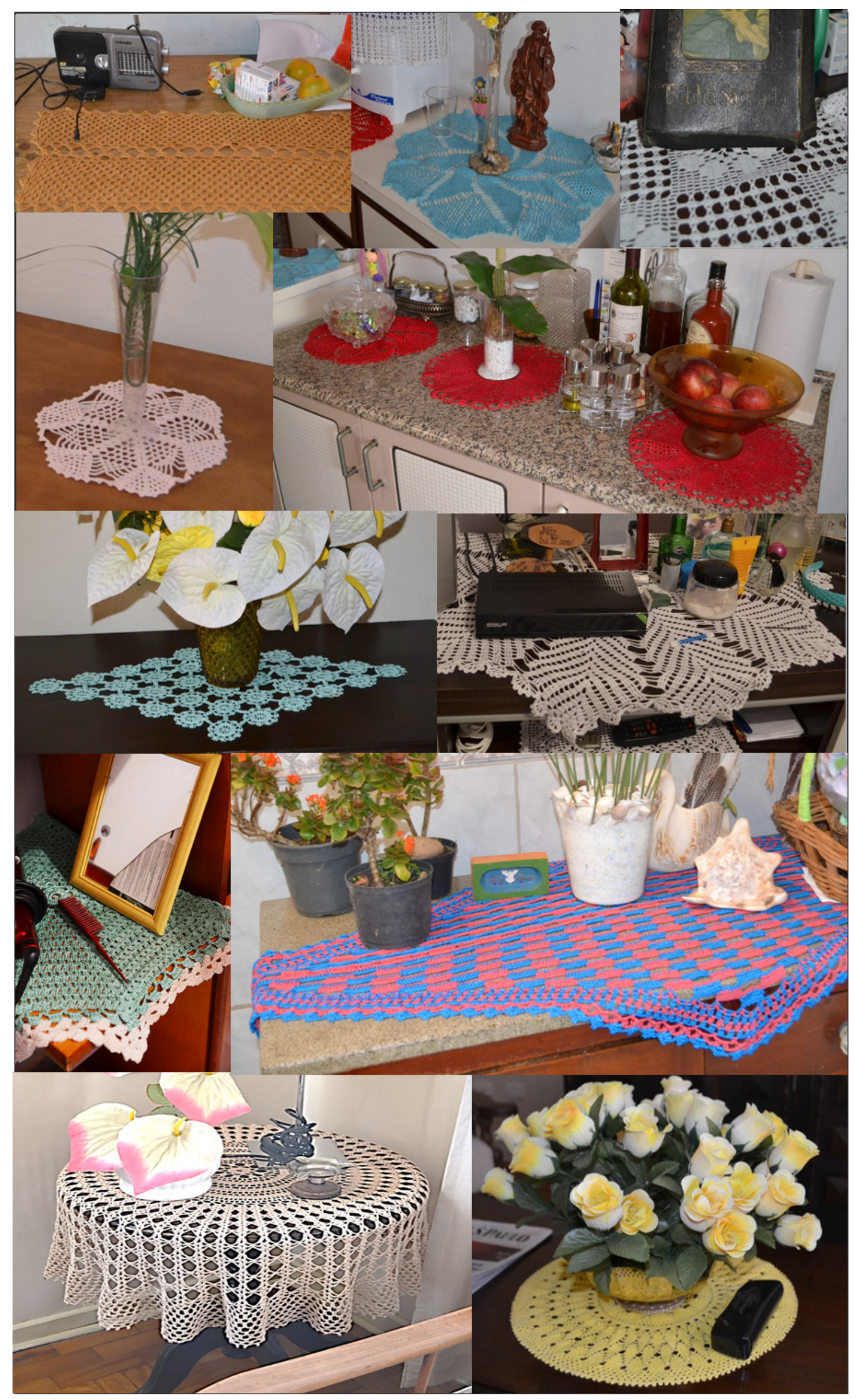




\section{Varal suspenso por bambu}

Aqui não se trata exatamente de um objeto e sim de uma solução. O varal suspenso por bambu é uma solução extremamente inteligente e pode ser observada em várias residências visitadas.

A inteligência reside no seguinte: geralmente, o varal cobre uma extensão muito grande, formando uma "barriga" no centro, o que impede que se pendurem roupas compridas nessa parte. Assim, ao utilizar-se o bambu para erguer a "barriga" do varal encaixando o fio em um corte feito no próprio bambu, aumenta-se o seu uso.

Vale ressaltar que o bambu é leve e, portanto, fácil de manejar. O peso da roupa trava o bambu no chão, fazendo com que este não escorregue e, ao mesmo tempo, permitindo que o varal inteiro balance ao vento, o que ajuda secar a roupa. 


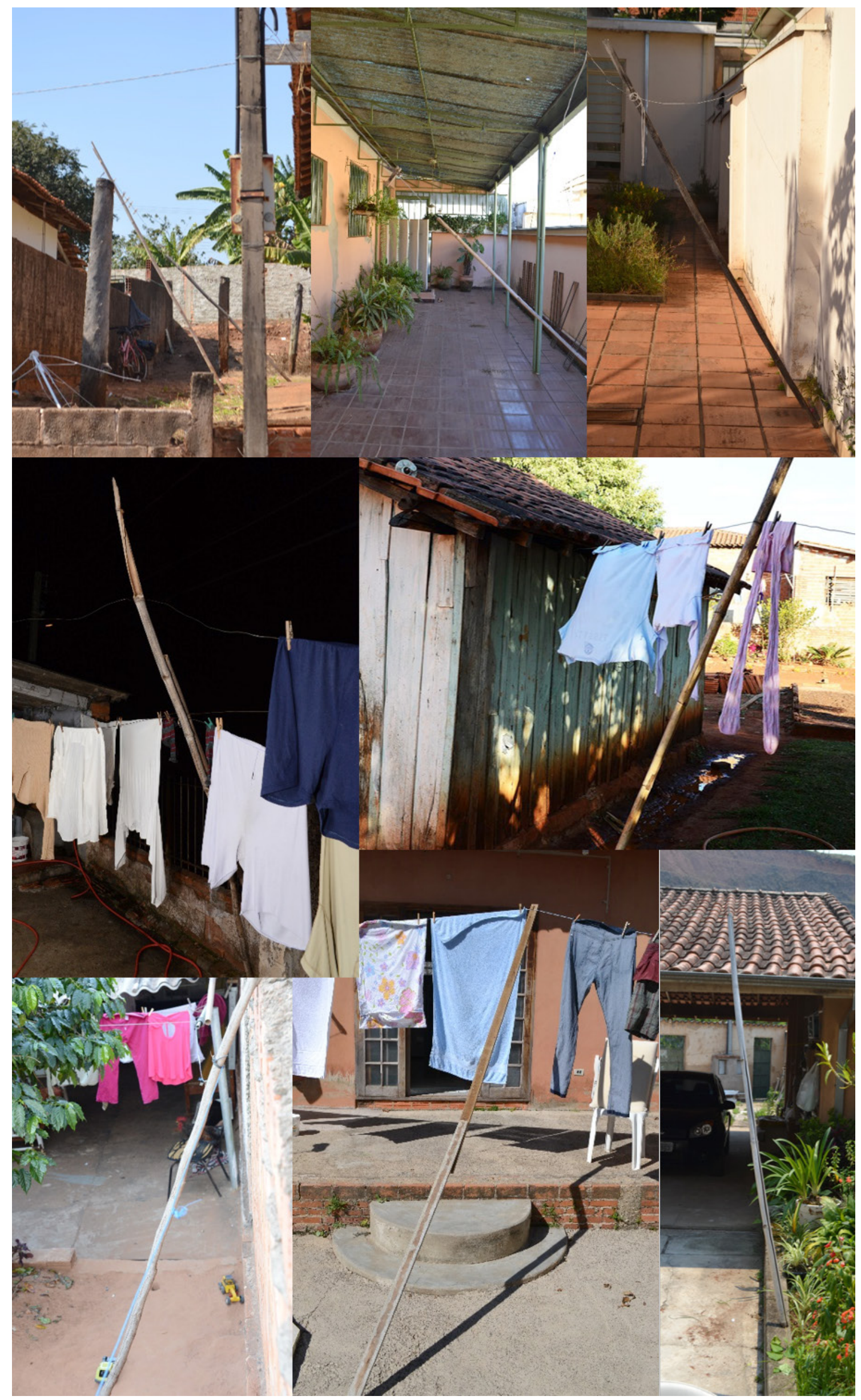




\section{Vasos de porcelana decorados}

Encontramos vasos de porcelana enfeitando mesas, estantes e aparadores pelas casas visitadas. Em todas as ocorrências, os vasos eram decorados; não foi encontrado nenhum exemplar liso, de uma só cor. Vários deles apresentam relevos e pinturas manuais de desenhos de flores; outros, são lisos em sua superfície, de formas mais limpas, apenas com estampas aplicadas, ou pinturas artesanais de desenhos florais. Em apenas um caso a decoração é de motivos geométricos em estilo futurista; nos demais, é orgânica e com motivos florais.

Os vasos podem estar acompanhados de flores, em sua maioria artificiais, sobre toalhinhas bordadas ou feitas em crochê. 


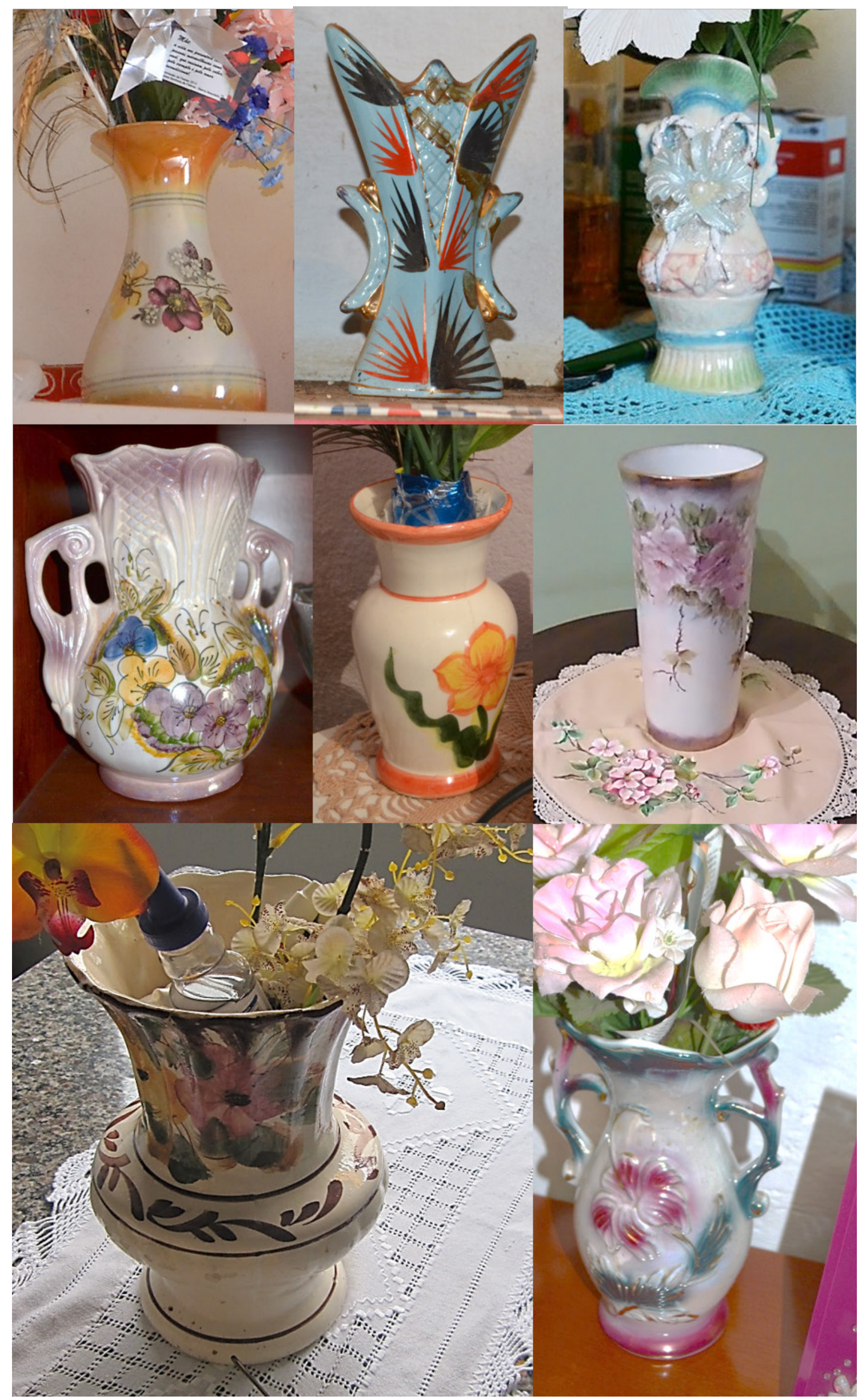




\section{Vassoura de palha}

A vassoura de palha é considerada pelos seus usuários como mais eficiente e duradoura do que a de plástico ou de piaçava. Em apenas um caso, a moradora relatou preferir a vassoura de plástico nova, mesmo sabendo que sua durabilidade é menor, em função da diferença no peso do objeto, queixando-se de não aguentar o peso da vassoura de palha, preferindo as novas, de plástico, por serem muito mais leves.

Do ponto de vista da ergonomia, a vassoura de palha, quando nova, é desconfortável para varrer, pois é rígida e sua base é reta. À medida que se usa, a palha se torna mais maleável e vai se desgastando de forma irregular, deixando sua base angulada e ligeiramente curva, o que melhora consideravelmente $o$ ato de varrer, ou seja, sua ergonomia.

A vassoura de palha, nas cidades visitadas, ainda é vendida de porta em porta, no mercado municipal e em algumas vendas. Em um caso específico, a entrevistada tem uma vassoura em uso e outras três guardadas, novas, pois relatou não saber quando o vendedor passará novamente.

Em uma residência na área rural da cidade de Limeira, pudemos acompanhar a produção da vassoura de palha, desde o arbusto de onde se tira os gravetos até sua amarração com arame e a colocação do cabo. As moradoras produzem para consumo próprio e um parente leva o excedente para vender na cidade, aos moldes da cultura caipira tradicional. 


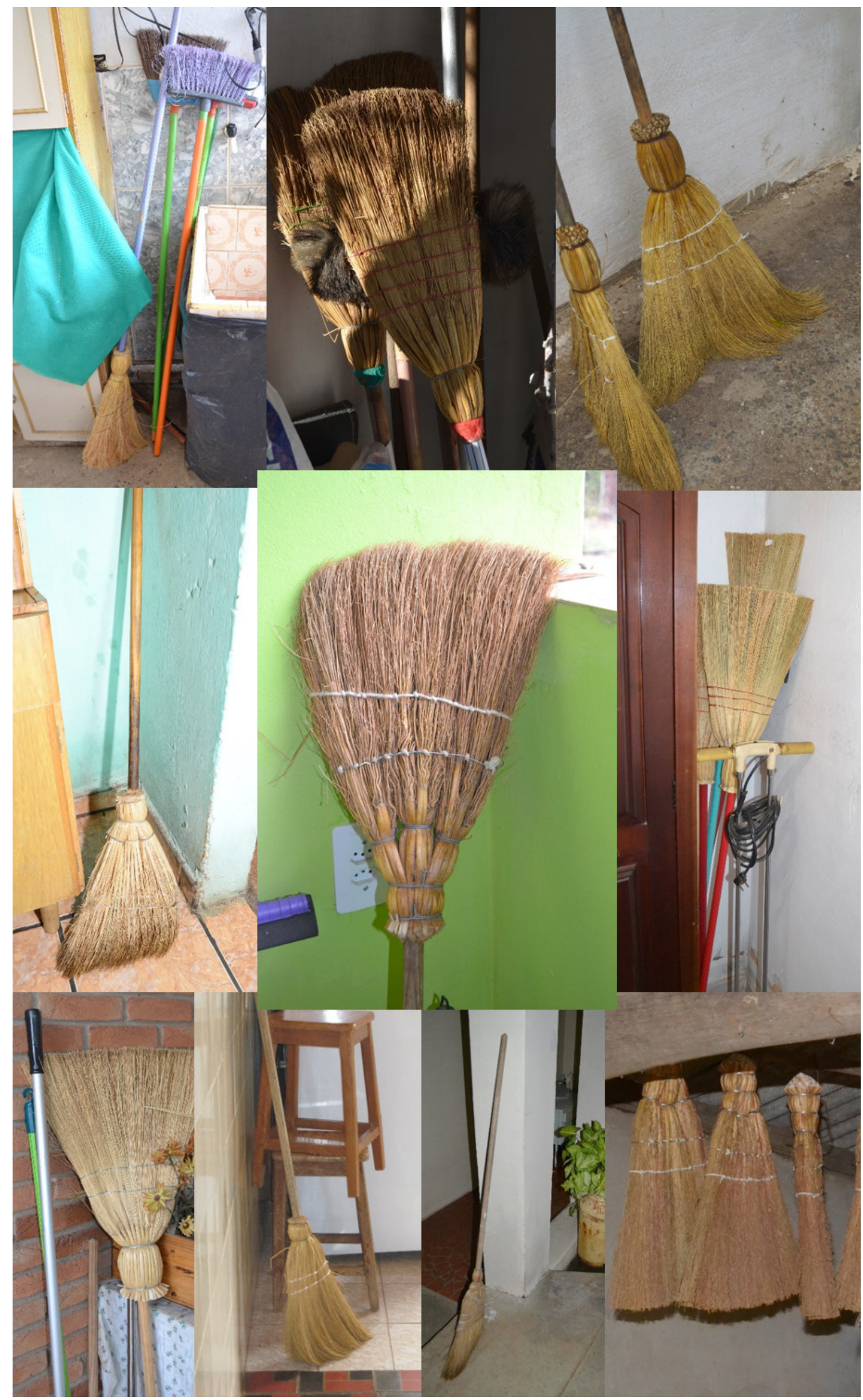




\section{Apêndice B - Questionário piloto}

\section{Pesquisa: Qual é a cara dos objetos que habitam nossa memória afetiva?}

\section{Introdução}

O presente questionário destina-se à coleta de dados de referência para a pesquisa de mestrado em Design, na FAU-USP, de Maria Beatriz Ardinghi, cujo objetivo é identificar e compreender o valor de certos objetos e arranjos presentes em nossa memória afetiva, para que, a partir daí, seja possível um estudo de sua qualidade estética e de linguagem, para servir de referência e inspiração na criação de novos designs.

Obrigada pela colaboração.

Maria Beatriz Ardinghi

1. Você costumava visitar avós ou outros parentes idosos em suas casas?

( ) $\operatorname{Sim}($ ) Não

\section{Página 2: Seus dados}
2. Nome completo:
3. Qual a sua idade:
4. Cidade/Estado onde nasceu:
5. Grau de escolaridade:
6. Profissão:

\section{Página 3: Questões}

7. Liste quais parentes você costumava visitar, a cidade/estado onde eles moravam e a época aproximada destas visitas. Por exemplo: tia avó; Araraquara, SP; década de 1980 até 1995. Avó; Piracicaba, SP; de 1970 até hoje.

8. Ao visitar seus avós ou parentes idosos, você se lembra de algum objeto ou arranjo típico de suas casas? Por favor, descreva cada um deles o mais detalhadamente possível e explique qual o seu sentimento associado a eles. 


\section{Anexo A - Cessão de direitos sobre depoimento oral e uso de imagem}

Pelo presente documento, eu

(nacionalidade)

(estado civil)

portador

do documento de identidade número emitido pelo

domiciliado na Rua

na cidade de

estado de

declaro

ceder, sem quaisquer restrições quanto aos seus efeitos patrimoniais e financeiros, a plena propriedade e os direitos autorais do depoimento de caráter documental que prestei a Maria Beatriz Ardinghi na cidade de bem como o uso das imagens fotográficas produzidas durante a entrevista.

A pesquisadora fica, consequentemente, autorizada a utilizar, divulgar e publicar para fins culturais, o mencionado depoimento no todo ou em partes, editado ou não, com a única ressalva de sua integridade e indicação da fonte e autor, bem como as imagens fotográficas realizadas.

Local e data:

Assinatura do Depoente:

Assinatura da Pesquisadora: 

